\title{
AKTUALSASI PANGISIL
}

\section{Dalam Berhagal Dimensi Kehidupan}

Pancasila harus selalu dijadikan pandangan hidup, pegangan hidup, pedoman hidup bangsa Indonesia atau lebih dikenal dengan wory of life. Di dalam menghadapi berbagai persoalan internal dan internasional, Pancasila harus tetap dijadikan pedoman di dalam mengatur kehidupan berbangsa dan bernegara melalui penyelenggaraan ketatanegaraan. Kedudukan Pancasila tidak hanya dipandang sebagai dasar negara, tetapi memiliki makna yang lebih jauh seperti ideologi nasional dan sekaligus mengandung makna tujuan dan cita-cita bangsa Indonesia. Memperhatikan kuatnya kedudukan Pancasila, maka sebagai anak bangsa memiliki kewajiban untuk mempertahankan, melestarikan, mengaktifkan nilai-nilai Pancasila tersebut. Kekuatan Pancasila adalah sangat identik dengan kekuatan Bangsa Indonesia sehingga kita bersama harus mencegah berbagai rongrongan baik yang berasal dari internal maupun dari eksternal.

Salah satu upaya yang dapat dilakukan adalah membumikan nilainilai Pancasila secara intensif guna memperkuat jati diri masyarakat yang beridentitas Pancasila. Penghayatan terhadap nilai-nilai Pancasila harus dilakukan melalui berbagai cara kepada masyarakat yang sangat beragam (suku, agama, ras dan antar golongan), sehingga dapat diamalkan dan diimplementasi secara baik dan benar. Nilai-nilai Ketuhanan dan keagamaan, kemanusian, persatuan, kerakyatan dan demokrasi serta keadilan sosial agar dapat terpatri di hati masyarakat Indonesia dan tidak mudah tercerai-berai. Nilai-nilai Pancasila harus dijadikan filter terhadap berbagai informasi, pandangan, ideologi yang masuk dari pihak eksternal sehingga dapat menangkal hal-hal yang tidak sesuai dengan Pancasila.

\section{Penerbit Lakeisha} II. Jatinom Boyolall $\mathrm{Km}$ 07 Srikalon, Pucangmilitan, Iulung, Klaten TIp/Wa. 08989880852 Instagram : penerbit lakeish Email: penerbit lakeisha@yahoe.com

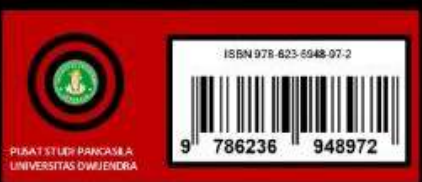

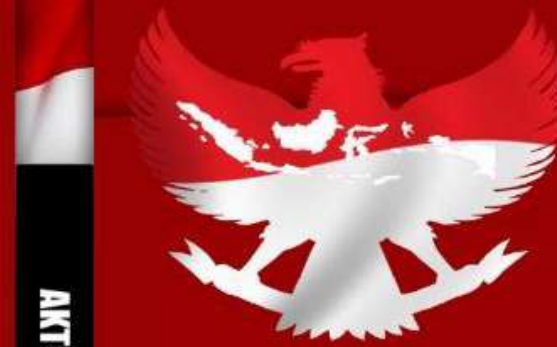

\section{AKIUMISISI PANGISII} Dalam Berbagai Dimensi Kehidupan
PUSAT STUDI PANCASILA UNIVERSITAS DWIJENDRA

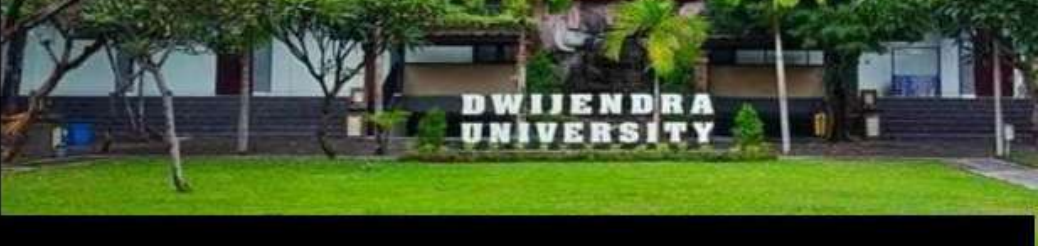

I Gusti Ngurah Santika, Gede Sedana, Made Sila,

I Wayan Eka Santika, I Gede Sujana, A.A. Istri Eka Krisna Yanti, Dewa Made Dwicky Putra Nugraha, I Putu Yoga Purandina,

I Wayan Kotaniartha, Dicky Marsadi, I Putu Yudi Sudarmawan, Ni Wayan Swarniti, Arya Bagus Mahadwijati Wijaatmaja, Gede Sutrisna 


\section{AKTUALISASI PANCASILA Dalam Berbagai Dimensi Kehidupan}




\section{Undang-Undang Republik Indonesia Nomor 28 Tahun 2014 tentang Hak Cipta}

Pasal 1:

1. Hak Cipta adalah hak eksklusif pencipta yang timbul secara otomatis berdasakan prinsip deklaratif setelah suatu ciptaan diwujudkan dalam bentuk nyata tanpa mengurangi pembatasan sesuai dengan ketentuan peraturan perundang-undangan.

Pasal 9:

2. Pencipta atau Pengarang Hak Cipta sebagaimana dimaksud dalam pasal 8 memiliki hak ekonomi untuk melakukan a.penerbitan Ciptaan; b.Penggandaan Ciptaan dalam segala bentuknya; c.Penerjemahan Ciptaan; d.Pengadaptasan, pengaransemen, atau pentrasformasian Ciptaan; e.Pendistribusian Ciptaan atau salinan; f.Pertunjukan Ciptaan; g.Pengumuman Ciptaan; h.Komunikasi Ciptaan; dan i. Penyewaan Ciptaan.

Sanksi Pelanggaran Pasal 113

1. Setiap Orang yang dengan tanpa hak melakukan pelanggaran hak ekonomi sebagaimana dimaksud dalam Pasal 9 ayat (1) huruf i untuk Penggunaan Secara Komersial dipidana dengan pidana penjara paling lama 1 (satu) tahun dan/atau pidana denda paling banyak Rp100.000.000 (seratus juta rupiah).

2. Setiap Orang yang dengan tanpa hak dan/atau tanpa izin Pencipta atau pemegang Hak Cipta melakukan pelanggaran hak ekonomi Pencipta sebagaimana dimaksud dalam Pasal 9 ayat (1) huruf $c$, huruf $d$, huruf $f$, dan/atau huruf $h$ untuk Penggunaan Secara Komersial dipidana dengan pidana penjara paling lama 3 (tiga) tahun dan/atau pidana denda paling banyak Rp500.000.000,00 (lima ratus juta rupiah). 


\section{AKTUALISASI PANCASILA Dalam Berbagai Dimensi Kehidupan}

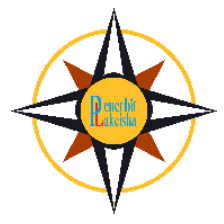

Penerbit Lakeisha

2021 


\section{AKTUALISASI PANCASILA Dalam Berbagai Dimensi Kehidupan}

Penulis:

I Gusti Ngurah Santika, Gede Sedana, Made Sila,

I Wayan Eka Santika, I Gede Sujana, A.A. Istri Eka Krisna Yanti,

Dewa Made Dwicky Putra Nugraha, I Putu Yoga Purandina,

I Wayan Kotaniartha, Dicky Marsadi, I Putu Yudi Sudarmawan,

Ni Wayan Swarniti, Arya Bagus Mahadwijati Wijaatmaja,

Gede Sutrisna

Editor :

I Gusti Ngurah Santika, S.Pd., M.Pd

Ni Wayan Swarniti, S.S., M.Hum

I Putu Edy Purnawijaya, S.Pd., M.Pd

I Made Astra Winaya, SPd., M.Pd

Layout : Yusuf Deni Kristanto

Design Cover : Tim Lakeisha

Cetak II Mei 2021

$14,8 \mathrm{~cm} \times 21 \mathrm{~cm}, 243$ Halaman

ISBN: 978-623-6573-44-0

Diterbitkan oleh Penerbit Lakeisha

(Anggota IKAPI No.181/JTE/2019)

Redaksi

Jl. Jatinom Boyolali, Srikaton, Rt.003, Rw.001, Pucangmiliran,

Tulung, Klaten, Jawa Tengah

Hp. 08989880852, Email: penerbit_lakeisha@yahoo.com

Website : www.penerbitlakeisha.com

Hak Cipta dilindungi Undang-Undang

Dilarang memperbanyak karya tulis ini dalam bentuk dan dengan cara apapun tanpa ijin tertulis dari penerbit 
emakin berkembangnya dinamika masyarakat dunia dan memberikan dampak pada tatanan kehidupan berbangsa dan bernegara di Indonesia, memerlukan adanya penguatan identitas bangsa yang berkesinambungan. Identitas bangsa Indonesia tidak dapat dilepaskan dari Pancasila sebagai ideologi negara. Pancasila harus semakin dimaknai sebagai pandangan hidup bangsa Indonesia di dalam bersikap dan bertingkah laku. Pancasila tidak lahir begitu saja, tidak juga berupa hadiah dari negeri manapun, namun Pancsila pada hakekatnya adalah cerminan nilai-nilai adat, tradisi, budaya, keagamaan/religi yang telah ada sejak Indonesia belum merdeka. Nilai-nilai tersebut merupakan modal sosial bagi masyarakat dan bangsa Indonesia di dalam mengisi kemerdekaan. Nilai-nilai kebudayaan, dan nilai religi yang terdapat dalam pandangan hidup masyarakat Indonesia. Modal sosial tersebut merupakan nilai-nilai local wisdom yang telah dimiliki dan diimplementasikan sebagai suatu pedoman berinteraksi sosial.

Pancasila harus selalu dijadikan pandangan hidup, pegangan hidup, pedoman hidup bangsa Indonesia atau lebih 
dikenal dengan way of life. Di dalam menghadapi berbagai persoalan internal dan internasional, Pancasila harus tetap dijadikan pedoman di dalam mengatur kehidupan berbangsa dan bernegara melalui penyelenggaraan ketatanegaraan. Kedudukan Pancasila tidak hanya dipandang sebagai dasar negara, tetapi memiliki makna yang lebih jauh seperti ideologi nasional dan sekaligus mengandung makna tujuan dan cita-cita bangsa Indonesia. Memperhatikan kuatnya kedudukan Pancasila, maka sebagai anak bangsa memiliki kewajiban untuk mempertahankan, melestarikan, mengaktifkan nilai-nilai Pancasila tersebut. Kekuatan Pancasila adalah sangat identik dengan kekuatan Bangsa Indonesia sehingga kita bersama harus mencegah berbagai rongrongan baik yang berasal dari internal maupun dari eksternal.

Salah satu upaya yang dapat dilakukan adalah membumikan nilai-nilai Pancasila secara intensif guna memperkuat jati diri masyarakat yang beridentitas Pancasila. Penghayatan terhadap nilai-nilai Pancasila harus dilakukan melalui berbagai cara kepada masyarakat yang sangat beragam (suku, agama, ras dan antar golongan), sehingga dapat diamalkan dan diimplementasi secara baik dan benar. Nilai-nilai Ketuhanan dan keagamaan, kemanusian, persatuan, kerakyatan dan demokrasi serta keadilan sosial agar dapat terpatri di hati masyarakat Indonesia dan tidak mudah tercerai-berai. Nilai-nilai Pancasila harus dijadikan filter terhadap berbagai informasi, pandangan, ideologi yang masuk dari pihak eksternal sehingga dapat menangkal hal-hal yang tidak sesuai dengan Pancasila.

Sebagai insan akademik, membumikan nilai-nilai Pancasila dapat dilakukan melalui penuangan pikiran, ide dan gagasan yang berkenaan dengan nilai-nilai Pancasila tersebut, masalah, tantangan dan upaya-upaya untyuk melestarikannya. Pikiran, ide dan gagasan dari para akademisi merupakan bagian dari sikap yang positif sebagai anak bangsa terhadap Pancasila sebagai ideologi negara 
dan pedoman hidup serta pemersatu bangsa. Oleh karena itu, saya memberikan apresiasi yang setinggi-tingginya kepada para penulis buku dalam bentuk Book Chapter yang berjudul Pancasila Dalam Berbagai Dimensi Kehidupan. Besar harapan saya adalah buku ini dapat menjadi salah satu kontribusi bagi bangsa dan negara untuk bersama-sama menjaga, mempertahankan dan melestarikan serta mengembangkan nilai-nilai Pancasila.

15 Mei 2021

Rektor Universitas Dwijendra

Dr. Ir. I Gede Sedana, M.Sc., M.MA 
eskipun sudah lebih dari tujuh dasa warsa ditetapkan
sebagai dasar negara Indonesia (state s philosophy) dan
pandangan hidup bangsa (way of life), pembumian Pancasila selalu saja tampil menjadi isu hangat yang tidak tergantikan dari masa ke masa. Walaupun sebenarnya usaha kearah itu sudah digencarkan dan digalakan mulai dari periode Pemerintahan Presiden Soekarno hingga Pemerintahan Presiden Jokowidodo. Tetapi sampai kini, pembumian Pancasila dalam kehidupan bermasyarakat, berbangsa, dan bernegara masih jauh dari kata sempurna. Dalam wacana publik semangat pembumian Pancasila begitu ramai diperbincangkan, tetapi sangat sepi teraktualisasi dalam tindakan nyata.

Belum teraktualisasinya Pancasila seharusnya menjadi bahan evaluasi dan refleksi bagi bangsa Indonesia ke depannya. Terdegradasinya aktualisasi Pancasila, sudah semestinya mampu merangsang dan mendorong berbagai pihak untuk ikut berperan serta membantu Pemerintah dalam upaya membumikan Pancasila. Seluruh komponen bangsa, terutama perguruan tinggi di Indonesia, wajib membumikan Pancasila sesuai dengan kedudukan dan perannya. Melalui Tri Dharma yang diembannya, perguruan tinggi 
tidak boleh hanya berdiam diri dan berpangku tangan menyaksikan Pancasila memudar dari ingatan kolektif bangsa Indonesia. Di sini perguruan tinggi dituntut untuk berpartisipasi aktif dalam mengkaji, mentransformasikan, dan mendiseminasikan, serta mengaktualisasikan Pancasila diberbagai sendi kehidupan.

Universitas Dwijendra sebagai salah satu Perguruan Tinggi Swasta (PTS) di Indonesia berkomitmen untuk senantiasa mengambil bagian positif dalam membumikan Pancasila melalui Tri Dharma Perguruan Tinggi. Komitmen Universitas Dwijendra terhadap pembumian Pancasila bukan hanya digelorakan dalam wacana akademis, tetapi dibuktikan melalui aktualisasi nyata. Untuk tahun ini saja dalam rangka menyambut Hari Lahir Pancasila yang diperingati setiap tanggal 1 Juni, Universitas Dwijendra melalui Pusat Studi Pancasila (PSP) menggagas pembumian Pancasila secara akademis melalui penulisan Book Chapter berjudul "Aktualisasi Pancasila Dalam Berbagai Dimensi Kehidupan”. Penulisan Book Chapter ini tidak hanya melibatkan dosen-dosen internal Universitas Dwijendra, tetapi juga dosen dari kampus lain.

Secara garis besarnya Book Chapter "Aktulisasi Pancasila Dalam Berbagai Dimensi Kehidupan” terdiri dari 14 tulisan. Sesuai judulnya, Book Chapter ini mengkaji Pancasila dari berbagai perspektif kehidupan. Dari sudut pandang kurikulum pendidikan tinggi, I Gusti Ngurah Santika dalam karyanya berjudul "Analisis Kritis Terhadap PP No. 57 Tahun 2021 Yang Menghapuskan Pancasila Dalam Muatan Kurikulum Pendidikan Tinggi” berupaya mengkritisi alasan Pemerintah yang tidak memasukan Pancasila sebagai muatan wajib kurikulum pendidikan tinggi; memprediksi implikasi yang mungkin timbul akibat penghapusan Pancasila dalam kurikulum perguruan tinggi; dan langkah yang harus diambil untuk menghakhiri polemik terkait hilangnya Pancasila dalam kurikulum perguruan tinggi. 
Dari sudut pandang pertanian, karya Gede Sedana berjudul "Penguatan Modal Sosial Subak Dalam Pelestarian Nilai-Nilai Pancasila" mampu membuktikan, bahwa modal sosial yang masih kuat pada sistem subak memiliki keterkaitan dengan nilai-nilai Pancasila di dalam kehidupan sehari-hari. Dengan bahasa yang mudah dimengerti Beliau mendeskripsikan penerapan nilai-nilai Pancasila dalam sistem subak; sistem subak dan modal sosial; nilainilai Pancasila pada sistem subak yang terdiri dari Nilai Ketuhanan Yang Maha Esa, Nilai Kemanusiaan yang adil dan beradab, Nilai Persatuan Indonesia, Nilai Kerakyatan yang dipimpin oleh khidmat kebijaksanaan dalam Permusyawaratan/Perwakilan, dan Nilai Keadilan sosial bagi seluruh rakyat Indonesia.

Hubungan antara nilai Pancasila dengan ajaran Tri Hita Karana dibahas oleh I Made Sila dalam karyanya berjudul "Implementasi Nilai-Nilai Pancasila Dalam Tri Hita Karana". Bahwa implementasi atau cerminan dari nilai-nilai Pancasila dalam suatu budaya atau ajaran dalam masyarakat Indonesia salah satunya dapat dilihat dalam konsep ajaran Tri Hita Karana. Dengan cara yang pandang berbeda I Waya Eka Santika dalam karyanya berjudul "Aktualisasi Nilai Pancasila Dalam Perspektif Tri Hita Karana Pada Masa Pandemi Covid-19" melihat bagaimana eksitensi dan kesaktian Pancasila dewasa ini ketika suasana Covid 19 melanda dunia. Pancasila kesaktiannya seolah diuji dalam membimbing bangsa indonesia agar tetap kuat dan tegar dalam menghadapai segala tantangan dan hambatn kehidupan bernegara

I Gede Sujana melalui karyanya berjudul "Urgensi Pancasila Dalam Menghadapi Globalisasi” menjelaskan berbagai keburukan yang muncul akibat globalisasi. Bahwa globalisasi membawa dampak negatif bagi nasionalisme dan hilangnya jati diri bangsa Indonesia. Oleh karena itu, diperlukan prestasi sebagai perekat kebangsaan. Tidak adanya prestasi dan kebanggaan yang dimiliki bangsa Indonesia menyebabkan lemahnya rasa kebangsaan atau nasionalisme dari setiap warga negara Indonesia. Di samping 
itu, bangsa Indonesia perlu merubah paradigma berpikir diagonalistik.

Pancasila dalam sistem hukum di Indonesia dikupas A.A. Istri Eka Krisna Yanti melalui karyanya berjudul "Kedudukan Pancasila Sebagai Sumber Hukum Dalam Pembentukan Peraturan Perundang-Undangan". Di dalamnya dibahas tentang kedudukan Pancasila pada sistem hukum Indonesia dan aktualisasi Pancasila dalam pembentukan peraturan perundang-undangan dengan menghadirkan teori dari Hans Nawiasky dan Hans Kelsen. Dewa Made Dwicky Putra Nugraha dalam tulisan berjudul "Aksiologi Pancasila dan Tantangan Di Tengah Disrupsi Pembelajaran" membahas secara aksiologis, bangsa Indonesia merupakan pendukung nilai-nilai Pancasila (subscriber of Pancasila value), yaitu bangsa yang berketuhanan, yang berkemanusiaan, yang berpersatuan, yang berkerakyatan dan berkeadilan sosial.

Dari sisi ketahanan nasional, I Putu Yoga Purandina melalui karyanya berjudul "Membangun Karakter Generasi Alpha Melalui Penerapan Nilai-Nilai Pancasila Sebagai Senjata Pamungkas Ketahanan Nasional" memaparkan jika nilai-nilai Pancasila dapat diterapkan sebagai jati diri Bangsa Indonesia ke depannya tentu akan menjadi sebuah senjata yang ampuh, perisai yang kuat untuk melawan rongrongan yang mengancam ketahanan nasional. I Wayan Kontaniartha dalam karyanya berjudul "Mewujudkan Kebebasan Pers Yang Bertanggungjawab Berdasarkan Pancasila" memandang perlu budaya sensor diri dalam media untuk dikembangkan mengingat sistem pers kita adalah sistem pers tanggung jawab sosial yang seharusnya menghargai nilai-nilai yang terkandung dalam falsafah bangsa, yakni Pancasila.

Terkait kebijakan import beras dijelaskan Dicky Marsadi dalam karyanya berjudul "Pentingnya Nilai Pancasila Dalam Kebijakan Import Beras" menilai, bahwa Pemerintah dalam mengambil kebijakan diharapkan mampu menerapkan nilai-nilai 
Pancasila agar setiap kebijakan atau tindakan yang diambilnya mampu memberikan dampak positif bagi seluruh rakyat Indonesia khususnya bagi petani padi. Dari segi pendidikan karakter, bahwa berlimpahnya nilai-nilai pendidikan karakter dan juga nilai-nilai Pancasila yang tersirat maupun tersurat dalam warisan leluhur kita, karya sastra yang tersaji dalam cerita rakyat. Hal itu dikemukakan I Putu Yudi Sudarmawan melalui karyanya berjudul "Pendidikan Karakter Dan Nilai-Nilai Pancasila Melalui Cerita Rakyat Pada Anak Usia Dini”".

Dari sudut pandang pembelajaran, Ni Wayan Swarniti melalui karyanya berjudul "Aplikasi Belajar Quizizz Sebagai Aktualisasi Pancasila Dalam Media Pembelajaran Bagi Mahasiswa Di Masa Pandemi Covid-19" mampu mendeskripsikan, bahwa penggunaan aplikasi belajar Quizziz adalah bagian dari aktualisasi Pancasila dalam pembelajaran daring. Arya Bagus Mahadwijati Wijaatmaja melalui karyanya berjudul "Tata Guna Lahan Dan Penataan Ruang Yang Berkeadilan Spasial" menjelaskan distribusi pembangunan yang tidak merata terjadi salah satunya karena tidak terwujudnya keadilan spasial (keruangan) dalam perencanaan pembangunan, baik itu tata ruang dan tata guna lahan. Tulisan terakhir berjudul "Pemanfaatan Google Classroom Untuk Memfasilitasi Self-Regulated Learning Dalam Pembelajaran Jarak Jauh Di Masa Pandemi Covid-19” karya I Gede Sutrisna.

Terbitnya Book Chapter ini tidak terlepas dari dukungan berbagai pihak, baik secara langsung maupun tidak langsung. Dalam kesempatan yang berbahagia ini, izinkan saya mengucapkan rasa terima kasih tidak terhingga kepada Dr. Ir. I Gede Sedana Rektor, M.Sc., MMA selaku Rektor Universitas Dwijendra yang senantiasa mendukung ide penulisan Book Chapter ini. Tanpa dukungan Beliau, tidak mungkin Book Chapter ini berada ditangan pembaca yang budiman. Apresiasi yang setinggi-tinggnya juga saya sampaikan kepada para penulis yang menyumbangkan pemikiran dan gagasannya dalam Book Chapter ini. Akhir kata, 
semoga Book Chapter ini mampu memberikan kontribusi yang berarti bagi pembumian Pancasila di Indonesia. Salam Pancasila!!!

Denpasar, 15 Mei 2021

Ketua Pusat Studi Pancasila Universitas Dwijendra

I Gusti Ngurah Santika, S.Pd., M.Pd 


\section{DAFTAR ISI}

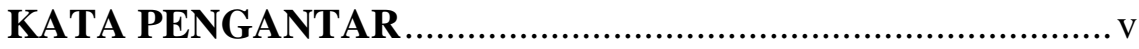

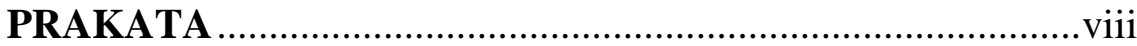

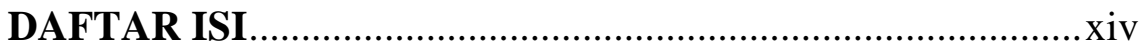

ANALISIS KRITIS TERHADAP PERATURAN

PEMERINTAH NOMOR 57 TAHUN 2021 YANG

MENGHAPUSKAN PANCASILA DALAM MUATAN KURIKULUM PENDIDIKAN TINGGI

I Gusti Ngurah Santika

PENGUATAN MODAL SOSIAL SUBAK DALAM PELESTARIAN_NILAI-NILAI PANCASILA

Gede Sedana

IMPLEMENTASI NILAI-NILAI PANCASILA DALAM KONSEP TRI HITA KARANA

Made Sila .43 
AKTUALISASI NILAI PANCASILA DALAM PERSPEKTIF TRI HITA KARANA PADA MASA PANDEMI COVID-19

I Wayan Eka Santika

\section{URGENSI PANCASILA DALAM MENGHADAPI} GLOBALISASI

I Gede Sujana .70

KEDUDUKAN PANCASILA SEBAGAI SUMBER HUKUM DALAM PEMBENTUKAN PERATURAN PERUNDANG-UNDANGAN

A.A. Istri Eka Krisna Yanti. .93

AKSIOLOGI PANCASILA DAN TANTANGANNYA DI TENGAH DISRUPSI PEMBELAJARAN

Dewa Made Dwicky Putra Nugraha 110

MEMBANGUN KARAKTER GENERASI ALPHA MELALUI PENERAPAN NILAI-NILAI PANCASILA SEBAGAI SENJATA PAMUNGKAS KETAHANAN NASIONAL

I Putu Yoga Purandina. 128

MEWUJUDKAN KEBEBASAN PERS YANG BERTANGGUNGJAWAB BERDASARKAN PANCASILA

I Wayan Kotaniartha 145

PENTINGNYA NILAI PANCASILA DALAM KEBIJAKAN IMPOR BERAS

Dicky Marsadi 161 
PENDIDIKAN KARAKTER DAN NILAI - NILAI PANCASILA MELALUI CERITA RAKYAT PADA ANAK USIA DINI

I Putu Yudi Sudarmawan

\section{APLIKASI BELAJAR QUIZIZZ SEBAGAI AKTUALISASI} PANCASILA DALAM MEDIA PEMBELAJARAN BAGI MAHASISWA DI MASA PANDEMI COVID-19

Ni Wayan Swarniti 186

TATA GUNA LAHAN DAN PENATAAN RUANG YANG BERKEADILAN SPASIAL

Arya Bagus Mahadwijati Wijaatmaja.... 210

PEMANFAATAN GOOGLE CLASSROOM UNTUK MEMFASILITASI SELF-REGULATED LEARNING DALAM PEMBELAJARAN JARAK JAUH DI MASA PANDEMI COVID-19

Gede Sutrisna 228 


\title{
ANALISIS KRITIS TERHADAP PERATURAN PEMERINTAH NOMOR 57 TAHUN 2021 YANG MENGHAPUSKAN PANCASILA DALAM MUATAN KURIKULUM PENDIDIKAN TINGGI
}

\author{
I Gusti Ngurah Santika \\ Fakultas Keguruan dan Ilmu Pendidikan Universitas Dwijendra \\ ngurahsantika88@gmail.com
}

\section{PENDAhuluan}

Melalui kewenangannya pada hari Rabu tanggal 30 Maret 2021 Presiden Jokowidodo telah menerbitkan Peraturan Pemerintah (PP) Nomor 57 Tahun 2021 tentang Standar Nasional Pendidikan (SNP). PP tersebut kemudian diundangkan Menteri Hukum dan Hak Asasi Manusia, Yasona H. Laoly pada tanggal 31 Maret 2021. Secara yuridis terdapat tiga pertimbangan yang mendasari lahirnya PP tersebut. Dalam pertimbangannya dijelaskan, bahwa pendidikan di Indonesia membutuhkan standar nasional yang memerlukan penyesuaian terhadap dinamika dan perkembangan ilmu pengetahuan, teknologi, serta kehidupan masyarakat untuk kepentingan peningkatan mutu pendidikan; bahwa untuk melaksanakan ketentuan Pasal 35 ayat (4), Pasal 36 ayat (4), Pasal 37 ayat (3), Pasal 59 ayat (3), Pasal 60 ayat (4), dan Pasal 61 ayat (4) Undang-Undang Nomor 20 Tahun 2003 tentang Sistem 
Pendidikan Nasional telah ditetapkan Peraturan Pemerintah Nomor 19 Tahun 2005 tentang Standar Nasional Pendidikan sebagaimana telah beberapa kali diubah, terakhir dengan Peraturan Pemerintah Nomor 13 Tahun 2015 tentang Perubahan Kedua atas Peraturan Pemerintah Nomor 19 Tahun 2005 tentang Standar Nasional Pendidikan; bahwa Peraturan Pemerintah Nomor 19 Tahun 2005 tentang Standar Nasional Pendidikan sebagaimana telah beberapa kali diubah, terakhir dengan Peraturan Pemerintah Nomor 13 Tahun 2015 tentang Perubahan Kedua atas Peraturan Pemerintah Nomor 19 Tahun 2005 tentang Standar Nasional Pendidikan belum dapat memenuhi kebutuhan sistem pendidikan saat ini, sehingga perlu diganti.

Tidak berselang lama setelah terbitnya PP No. 57 Tahun 2021 tentang Standar Nasional Pendidikan, polemik pun mulai muncul, merebak, dan berkembang luas di masyarakat. Keberadaan PP ini rupanya melahirkan kritikan pedas dan penolakan keras dari berbagai kalangan, khususnya mereka yang fokus perhatiannya di bidang pendidikan. Disengaja atau tidak, bahwa terbitnya PP tersebut telah menghapuskan atau menghilangkan Pancasila sebagai muatan wajib kurikulum mulai dari jenjang pendidikan dasar, pendidikan menengah, dan pendidikan tinggi. Ketentuan penghapusan Pancasila dari muatan wajib kurikulum dapat diketahui dari bunyi Pasal 40 Ayat 2 dan 3 PP No. 57 Tahun 2021. Di dalam ketentuannya itu disebutkan, bahwa kurikulum pendidikan dasar dan pendidikan menengah memuat pendidikan agama; pendidikan kewarganegaraan; bahasa; matematika; ilmu pengetahuan alam; ilmu pengetahuan sosial; seni dan budaya; pendidikan jasmani dan olahraga; keterampilan/kejuruan; dan muatan lokal. Sedangkan untuk kurikulum pendidikan tinggi wajib memuat pendidikan agama; pendidikan kewarganegaraan; dan bahasa. Tidak dimasukannya Pancasila dalam muatan wajib kurikulum tentu saja memunculkan tanggapan miring, protes, 
hingga kecaman dari berbagai pihak yang peduli dengan kondisi bangsa Indonesia.

Pusat Studi Pancasila Universitas Gadjah Mada (PSP UGM) melalui siaran persnya yang dilakukan secara daring pada hari Kamis 15 April 2021 mengeluarkan beberapa pandangan. Dalam point 5 nya, PSP UGM menyatakan dan menegaskan pandangannya, bahwa menghapus pendidikan Pancasila sebagai kurikulum wajib, apalagi hanya Pancasila saja yang dihapus merupakan tindakan yang berbahaya, karena potensial mengubur Pancasila dalam upaya Pembudayaan Pancasila melalui jalur Pendidikan Nasional. Secara politik, jika agama dan kewarganegaraan adalah penting dan diwajibkan, maka penghapusan Pancasila adalah menghapus landasan sebagai nilai moral. Maka hal ini akan membayakan bagi masa depan Negara Kesatuan Republik Indonesia (PSP UGM, 2021). Sejarawan Asvi Warman Adam menilai pemerintah sangat sembrono menghilangkan mata kuliah pendidikan dasar Pancasila ... di kurikulum sekolah dan pendidikan tinggi. Akibatnya ancaman disintegrasi bangsa semakin terbuka (Tempo, 2021). Ketua Komisi X DPR RI, Syaiful Huda berpendapat, bahwa Pendidikan Pancasila harus eksplisit masuk sebagai mata pelajaran wajib dalam kurikulum pendidikan nasional. Menurutnya keberadaan pendidikan Pancasila tidak bisa diganti dengan pendidikan kewarganegaraan sebagaimana tertuang dalam PP Standar Nasional Pendidikan (CNN, 2021).

Berdasarkan permasalahan tersebut, dipandang perlu dilakukan analisis secara logis, kritis, dan mendalam terhadap keberadaan PP No. 57 Tahun 2021 yang menghilangkan Pancasila sebagai muatan wajib kurikulum pada pendidikan tinggi. Perlu digali, diungkap, dan dibuka secara terang-menderang alasan yang sesungguhnya mendasari Pemerintah mengapa Pancasila tidak dimasukan sebagai muatan wajib kurikulum pendidikan tinggi 
dalam PP No. 57 Tahun 2021 tentang Standar Nasional Pendidikan. Dengan begitu, akan diketahui secara pasti mengapa PP tersebut tidak mencantumkan Pancasila dalam muatan kurikulum pendidikan tinggi. Selain itu, implikasi apa yang mungkin timbul dalam kehidupan berbangsa dan bernegara akibat penghapusan Pancasila sebagai muatan wajib kurikulum di pendidikan tinggi. Terus langkah apa yang sekiranya harus diambil berbagai pihak, baik itu Pemerintah maupun stakeholder untuk menghakhiri polemik yang berkembang di masyarakat terkait tidak dicantumkannya Pancasila dalam kurikulum pendidikan tinggi.

\section{PEMBAHASAN}

\subsection{Mengkiritisi Alasan Pemerintah Tidak Memasukan Pancasila Sebagai Muatan Wajib Kurikulum Perguruan Tinggi}

Pemerintah memiliki alasan tersendiri mengapa Pancasila tidak dicantumkan dalam PP No. 57 Tahun 2021. Menurut Nadiem, bahwa PP Standar Nasional Pendidikan ini disusun dengan merujuk pada Undang-Undang Nomor 20 Tahun 2003 tentang Sistem Pendidikan Nasional dan PEMBAHASAN kurikulum wajib tertulis persis dengan UU tersebut (CBNC, 2021). Untuk lebih meyakinkan lagi, bahwa alasan Mendikbud tersebut dapat diketahui dari pertimbangan kedua PP No. 57 Tahun 2021 yang menyatakan "bahwa untuk melaksanakan ketentuan Pasal 35 ayat (4), Pasal 36 ayat (4), Pasal 37 ayat (3), Pasal 59 ayat (3), Pasal 60 ayat (4), dan Pasal 61 ayat (4) Undang-Undang Nomor 20 Tahun 2003 tentang Sistem Pendidikan Nasional telah ditetapkan Peraturan Pemerintah Nomor 19 Tahun 2005 tentang Standar Nasional Pendidikan sebagaimana telah beberapa kali diubah, terakhir dengan Peraturan Pemerintah Nomor 13 Tahun 2015 tentang Perubahan Kedua atas Peraturan Pemerintah Nomor 19 Tahun 2005 tentang Standar Nasional Pendidikan. 
Bila ditelusuri kembali dalam UU No. 20 Tahun 2003 sebagaimana pernyataan Mendikbud, maka sesungguhnya tidak ada yang keliru dengan muatan wajib kurikulum dalam Pasal 40 ayat (2) dan (3) PP No. 57 Tahun 2021. Hal itu bisa diketahui dari dua PEMBAHASAN peraturan perundang-undangan tersebut, terutama pada bagian yang mengatur masalah kurikulum. Mengingat dalam Bab X Kurikulum pada Pasal 37 ayat (1) UU No. 20 Tahun 2003 berbunyi "Kurikulum pendidikan dasar dan menengah wajib memuat: (a) pendidikan agama; (b) pendidikan kewarganegaraan; (c) bahasa; (d) matematika; (e) ilmu pengetahuan alam; (f) ilmu pengetahuan sosial; (g) seni dan budaya; (h) pendidikan jasmani dan olahraga; (i) keterampilan/kejuruan; dan (j) muatan lokal. Sedangkan Pasal 37 ayat (2) dinyatakan, bahwa Kurikulum pendidikan tinggi wajib memuat: a. pendidikan agama; $b$. pendidikan kewarganegaraan; dan c. bahasa.

Jadi pada dasarnya muatan wajib kurikulum dalam PP No. 57 Tahun 2021 sebagai peraturan yang berada di bawah UU No. 20 Tahun 2003 hanya meng-copy paste ketentuan yang ada di atasnya. Tetapi sudah dapat dipastikan, bahwa lahirnya PP ini tentunya dimasa depan akan memicu polemik dan kontroversi berkepanjangan di tengah masyarakat akademis, utamanya kalangan pendidikan tinggi. Mengingat Pasal 40 Ayat (3) PP No. 57 Tahun 2021 bukan hanya tidak mencantumkan Pancasila sebagai muatan wajib kurikulum di pendidikan dasar dan menengah, tetapi juga menghilangkan Pancasila dalam muatan wajib kurikulum di pendidikan tinggi. Padahal dalam Pasal 35 UU No. 12 Tahun 2012 secara gamblang disebutkan, bahwa kurikulum pendidikan tinggi wajib memuat Agama, Pancasila, Kewarganegaraan, dan Bahasa Indonesia. Sudah seharusnya dalam menyusun PP No. 57 Tahun 2021 yang mengatur tentang muatan wajib kurikulum untuk pendidikan tinggi, Pemerintah tidak boleh hanya berpegangan, berpaku, dan berpedoman pada UU No. 20 Tahun 2003. Karena terkait muatan wajib kurikulum untuk 
pendidikan tinggi secara khusus sudah diatur dalam UU No. 12 Tahun 2012.

Dalam situasi seperti ini, Pemerintah sepertinya kurang cermat dan teliti dalam menyusun PP No. 57 Tahun 2021 terkait kurikulum pendidikan tinggi. Kecerobohan tersebut dapat dilihat dari asas hukum (legal principle) yang dilabrak Pemerintah dalam menyusun No. 51 Tahun 2021 yang menghilangkan Pancasila sebagai kurikulum wajib di pendidikan tinggi. Sudah seharusnya Pemerintah ketika menyusun PP No. 57 Tahun 2021 yang mengatur kurikulum pendidikan tinggi wajib berpegang teguh pada prinsip hukum Asas lex specialis derogat legi generali. Asas lex specialis derogat legi generali bermakna undang-undang (norma/aturan hukum) yang khusus meniadakan keberlakuan undang-undang (norma/aturan hukum) yang umum (Irfani, 2020). Rasionalitas pengutamaan UU No. 12 Tahun 2012 adalah karena aturan hukum tersebut bersifat khusus yang tentunya lebih relevan dan kompatibel, serta lebih sesuai dengan kebutuhan dan subjek yang lebih spesifik, sehingga tidak mampu dijangkau UU No. 20 Tahun 2003 yang bersifat umum. Adanya perbedaan muatan wajib kurikulum dalam UU 20 Tahun 2003 dengan UU 12 Tahun 2012, karena UU Sistem Pendidikan Nasional merupakan ketentuan hukum yang bersifat umum. Jadi UU No. 12 Tahun 2012 tentang Pendidikan Tinggi sebagai ketentuan hukum khusus adalah bermaksud untuk melengkapi atau melakukan perbaikan atau koreksi terhadap UU No. 20 Tahun 2003 yang mengatur tentang kurikulum wajib pendidikan tinggi.

Di samping tidak taat dengan asas hukum lex specialis derogat legi generali, penyusunan PP No. 57 Tahun 2021 terkait kurikulum wajib pendidikan tinggi juga tidak mengikuti asas hukum Lex Posterior Derogat Legi Prior. Asas lex posterior derogat legi priori bermakna undang-undang (norma/aturan hukum) yang baru meniadakan keberlakuan undang-undang (norma/aturan hukum) yang lama. Undang-Undang yang baru 
mengesampingkan Undang-Undang yang lama, maksudnya jika ada Undang-Undang yang mengatur tentang suatu hal diganti atau diperbaharui dengan Undang-Undang yang baru, maka UndangUndang yang lama tidak berlaku lagi. Asas ini seharusnya digunakan sebagai dasar dan patokan bagi Pemerintah dalam penyusunan PP No. 57 Tahun 2021 menyangkut muatan wajib kurikulum di pendidikan tinggi. Mengingat UU No. 12 Tahun 2012 adalah norma hukum baru yang memiliki kedudukan sederajat dengan UU No. 20 Tahun 2003 yang merupakan norma hukum lama. Sudah seharusnya ketentuan UU No. 12 Tahun 2012 yang mengatur muatan wajib kurikulum pendidikan tinggi mengesampingkan ketentuan serupa dalam UU No. 20 Tahun 2003.

\subsection{Implikasi Yang Kemungkinan Timbul Akibat Penghapusan Pancasila Dalam Kurikulum Perguruan Tinggi.}

Sudah menjadi rahasia umum, bahwa Pancasila memiliki kedudukan yang sangat vital dan fundamental bagi eksistensi bangsa Indonesia. Sejak awal digali, dirumuskan, disusun, dan diperdebatkan, Pancasila memang dimaksudkan untuk ditetapkan menjadi dasar negara Indonesia. Meskipun melalui proses yang berliku tajam dan sangat menegangkan, Pancasila pun pada 18 Agustus 1945 berhasil disahkan PPKI sebagai dasar negara Indonesia. Dengan kedudukannya sebagai dasar negara, tentunya Pancasila memiliki implikasi bagi kehidupan berbangsa dan bernegara. Sebagai dasar negara Indonesia, Pancasila memperoleh posisi yang terhormat, yaitu sebagai sumber dari segala sumber hukum. Hal itu dapat dilihat mulai dari Ketetapan MPR/S Nomor XX Tahun 1966, Ketetapan MPR Nomor III Tahun 2000, UU No. 10 Tahun 2004, dan UU No. 12 Tahun 2011 yang mengatur peraturan perundang-undangan di Indonesia. Kedudukan Pancasila sebagai sumber dari segala sumber hukum mempunyai makna penting, bahwa sistem hukum nasional wajib berlandaskan Pancasila. Tidak boleh ada hukum yang dibentuk di Indonesia tanpa dijiwai Pancasila. 
Selain sebagai dasar negara, perlu dicamkan bersama, bahwa Pancasila merupakan warisan luar biasa dari pendiri bangsa yang mengacu kepada nilai-nilai luhur. Hampir tidak ada keraguan lagi, mayoritas bangsa Indonesia ini berpendapat, bahwa Pancasila sebagai dasar negara sekaligus pandangan hidup masyarakat Indonesia yang plural tidak tergantikan (Putri, 2012). Terbukti hingga sekarang berbagai upaya yang dilakukan pengkhianat bangsa untuk merobohkan Pancasila, tidak pernah berhasil. Pancasila selalu berhasil mempersatukan rakyat Indonesia untuk berdiri dibelakangnya dan membela mati-matian. Dalam situasi seperti ini, Pancasila mampu mempersatukan segala aliran maupun perbedaan yang berkembang di masyarakat. Jadi secara empirishistoris sejak digali, dirumuskan, dan diperdebatkan Pancasila oleh the founding father sesungguhnya membuktikan fungsi integratifnya yang menjamin persatuan dan kesatuan negara bangsa Indonesia yang pluralistik. Pancasila sebagai pemersatu bangsa dalam perjalanannya sudah terbukti dan teruji oleh zaman (Santika, 2019). Tidak terbayangkan bagaimana jadinya Indonesia tanpa Pancasila. Tanpa Pancasila Indonesia dapat dipastikan selalu gaduh dan tidak akan pernah bersatu dalam perbedaan sebagaimana adanya sekarang. Secara historis-empiris Pancasila berhasil menjembatani keberagaman sekaligus memperkokoh persatuan Indonesia.

Di samping itu, Pancasila sebagai pandangan hidup memiliki fungsi yang tidak kalah fundamentalnya bagi Indonesia. Sebagai pandangan hidup bangsa, Pancasila merupakan cerminan atau refleksi kepribadian dari setiap orang Indonesia dimana pun berada. Karena itu sudah seharusnya Pancasila dijadikan barometer dan acuan normatif bagi bangsa Indonesia dalam berpikir, berkata, dan berperilaku. Sebab dengan kepribadian Pancasila itulah bangsa Indonesia memiliki identitas (identity) yang dapat membedakannya dengan bangsa lain. Hal ini memberikan identitas dan martabat sebagai bangsa yang beradab, sekaligus memiliki jiwa dan kepribadian yang religius. 
Dengan kepribadian Pancasila, manusia Indonesia memiliki identitas yang digunakannya sebagai dasar dalam pergaulannya sehari-hari.

Sayangnya dengan kedudukan se-vital itu, Pancasila oleh penguasa belum diberikan posisi yang sesuai dan proporsional dalam kehidupan bermasyarakat, berbangsa, dan bernegara. Akibat dosa penguasa dimasa lalu, pasca reformasi Pancasila kian dilupakan, dipinggirkan, dan ditinggalkan, serta dicabut dari segala bidang kehidupan. Pancasila tidak diberikan kesempatan untuk tumbuh dalam sanubari rakyat Indoneia. Pancasila setelah refomasi seolah-olah kehilangan relevansinya dalam kehidupan bernegara. Pancasila tetap menjadi ideologi bangsa tetapi tidak memiliki peran yang berarti. Sebagian orang yang tidak memahami sejarah menganggap Pancasila sudah selesai dengan peran masa lalunya. Pancasila tidak perlu lagi dibumikan secara khusus melalui pendidikan. Pembudayaan Pancasila melalui jalur pendidikan nasional pun mulai dilirik sebelah mata dan dipandang tidak relevan lagi.

Karena itulah sebabnya Pancasila dinilai tidak terlalu penting masuk dalam kurikulum pendidikan tinggi sebagai muatan wajib. Sebagian besar orang yang tidak paham sejarah ideologis menganggap materi Pancasila sebagai hapalan belaka, sehingga cukup dijadikan sisipan dalam mata kuliah pendidikan kewarganegaraan. Tidak masuknya Pancasila sebagai muatan wajib kurikulum pendidikan tinggi menurut PP No. 57 Tahun 2021 memang patut disayangkan. Dan fenomena meredupnya Pancasila dalam sistem pendidikan nasional, khususnya kurikulum harus menjadi perhatian bersama. Mengingat kurikulum mempunyai kedudukan dan peran sentral dalam keseluruhan proses pendidikan di Indonesia. Bahkan kalau boleh dikatakan, bahwa kurikulum merupakan jantungnya pendidikan di Indonesia (Santika, 2021). Secara umum, kurikulum bertujuan sebagai arah, pedoman, atau sebagai rambu-rambu dalam pelaksanaan proses pembelajaran 
(belajar mengajar). Kurikulum mengarahkan segala bentuk aktivitas pendidikan demi tercapainya tujuan pendidikan yang telah ditetapkan.

Penghapusan Pendidikan Pancasila secara halus dalam kurikulum sebenarnya dapat diketahui, sejak diberlakukannya UU No. 20 Tahun 2003. Redupnya populeritas Pancasila dalam pendidikan, paling tidak mengakibatkan generasi muda Indonesia pasca-reformasi kehilangan arah dan rujukan penting tentang hakikat hidup bernegara yang baik dan tepat. Tidak mengherankan bila banyak generasi muda Indonesia yang salah jalan, sehingga terjerembab ke dalam jurang yang dalam. Bahkan menurut temuan BNPT 85 persen generasi milenial rentan terpapar paham radikal. Tentunya hasil survey yang dirilis BNPT patut menjadi perhatian serius bersama. Jangan sampai hilangnya Pancasila dalam kurikulum pendidikan tinggi justru memberikan kesempatan seluas-luasnya bagi tumbuh suburnya ideologi-ideologi lain yang notabene justru bertentangan dengan kepribadian bangsa. Dalam kondisi seperti ini, mahasiswa yang sudah terbukti memiliki posisi sebagai agen perubahan (agen of change) menjadi sangat rentan disusupi ideologi-ideologi yang berseberangan dengan Pancasila. Ideologi asing pun menjadi ancaman nyata mahasiswa sebagai generasi penerus bangsa ketika Pancasila mulai diabaikan dalam pendidikan tinggi. Bila hal itu benar-benar terjadi, Indonesia yang dibangun atas dasar keberagaman berpotensi dicabik-cabik oleh ideologi asing yang membawa paham destruktif.

Dihapuskannya Pancasila dalam kurikulum pendidikan tinggi menurut PP No. 57 Tahun 2021 paling tidak membuat mahasiswa kehilangan rujukan dalam kehidupan berbangsa dan bernegara. Kebijakan tersebut tanpa disadari telah menjauhkan dan mengasingkan Pancasila dari kehidupan mahasiswa. Implikasinya adalah mahasiswa tidak lagi menganggap penting Pancasila dalam kehidupan bernegara. Bagaimana jadinya bangsa Indonesia, bila Pancasila yang merupakan ideologinya malah berada jauh dengan 
relung batin mahasiswa. Padahal ke depannya mahasiswa adalah tumpuan bangsa yang berperan melanjutkan estapet kepemimpinan negara di masa depan. Merekalah nantinya yang menduduki jabatan di lembaga eksekutif, legislatif dan yudikatif. Betapa mengerikan apabila membayangkan mahasiswa sebagai calon pemimpin bangsa, tidak memahami, mengerti, dan mengaktualisasikan Pancasila dalam kehidupannya sehari-hari. Kemungkinan besar ketika duduk menjadi legislator, peraturan perundang-undangan yang dibuat bertentangan dengan Pancasila. Belum lagi saat menjabat dilembaga eksekutif, kemungkinan menjalankan kekuasaan secara semana-mena dan tangan besi. Bisa jadi pemerintahan diselenggarakannya jauh dari nilai-nilai Pancasila. Belum lagi waktu mendapatkan kesempatan menjadi wakil Tuhan di dunia, yaitu sebagai hakim. Bila dalam menjalankan kewenangannya tidak berpedoman pada Pancasila, mustahil putusannya menghasilkan keadilan.

Jadi tidak diakomodirnya Pancasila dalam kurikulum pada jenjang pendidikan tinggi tentunya membawa konsekuensi logis ditinggalkannya nilai-nilai luhur tersebut oleh mahasiswa. Nilainilai luhur seperti religusitas, kemanusiaan, musyawarah, gotong royong, kerukunan, dan toleransi beragama semakin kering dalam kehidupan kampus. Padahal dalam konteks kekinian nilai-nilai fundamental seperti itu sangat dibutuhkan Indonesia sebagai bangsa pluralistis untuk tetap mempertahankan dan menjaga keutuhannya. Dihapuskanya Pancasila dalam kurikulum pendidikan tinggi menjadi permasalahan besar, ditengah persatuan dan kesatuan bangsa Indonesia yang selalu mendapatkan cobaan. Mahasiswa selama ini tidak mampu mengambil peran positifnya sebagai agen pemersatu bangsa. Malah yang ada berkebalikan, bahwa mahasiswa memposisikan diri sebagai golongan intelektual yang membawa sifat desktruktif bagi persatuan bangsa dan negara. Berarti kehidupan kampus yang jauh dari Pancasila pada gilirannya hanya mampu melahirkan mahasiswa yang cerdas secara 
intelektual. Pendidikan tinggi tanpa Pancasila ternyata gagal dalam mencetak mahasiswa yang cerdas secara spiritual, moral dan emosional.

\subsection{Langkah Yang Harus Diambil Untuk Menghakhiri Polemik Terkait Hilangnya Pancasila Dalam Kurikulum Perguruan Tinggi.}

Persoalan paling mendasar tidak dimasukannya Pancasila dalam kurikulum pendidikan tinggi bukan hanya dijumpai pada Pasal 40 ayat (2) dan (3) PP No. 57 Tahun 2021, melainkan juga di Pasal 37 ayat (1) dan (2) UU No. 20 Tahun 2003. Berlainan dengan Pasal 35 ayat (3) UU No. 12 Tahun 2012 yang mewajibkan Pancasila masuk sebagai mata kuliah berdiri sendiri dalam kurikulum pendidikan tinggi. Dari perspektif hukum, tidak dimasukannya Pancasila dalam kurikulum wajib dipendidikan tinggi sebagaimana diatur PP No. 57 Tahun 2021 jelas sebuah kekeliruan besar. Dihilangkannya Pancasila dalam kurikulum pendidikan tinggi justru menambah polemik, kontroversi, dan kegaduhan yang membingungkan di masyarakat. Mengingat Pancasila dari perspektif sosiologis, sudah diyakini kesaktian dan keampuhannya sepanjang masa oleh bangsa Indonesia. Oeh karena itu, dipandang perlu dicarikan solusi dan jalan terbaik untuk mengatasi permasalahan yang muncul akibat tidak dicantumkannya Pancasila dalam kurikulum pendidikan tinggi.

Karena problematika ini muncul pada tataran norma peraturan perundang-undangan, maka penyelesaiannya harus dilakukan secara legal-konstitusional. Persoalan itu dapat dicermati dari terjadi konflik norma antara UU No. 12 Tahun 2012 dengan PP No. 57 Tahun 2021, maka mau tidak mau, pengujian peraturan perundang-undangan harus dilakukan (yudicial review). Tindakan yudicial review memiliki landasan yang sangat kuat dalam menjaga dan menyelaraskan peraturan hukum yang berlaku. Dengan begitu, dalam konsep hierarki peraturan perundangan tidak diperbolehkan adanya pertentangan antara norma hukum yang kedudukannya 
lebih rendah dengan norma hukum yang kedudukannya lebih tinggi. Kalau diperhatikan dari UU No 12 Tahun 2011, maka dapat buktikan, bahwa peraturan perundang-undangan Indonesia juga memiliki hierarki. Pasal 7 ayat (1) UU No. 12 Tahun 2011 tentang Peraturan Perundang-Undangan menyatakan, bahwa Jenis dan hierarki Peraturan Perundang-undangan terdiri atas: (a). UndangUndang Dasar Negara Republik Indonesia Tahun 1945; (b.) Ketetapan Majelis Permusyawaratan Rakyat; (c). UndangUndang/Peraturan Pemerintah Pengganti Undang-Undang; (d). Peraturan Pemerintah; (e). Peraturan Presiden; (f). Peraturan Daerah Provinsi; dan (g). Peraturan Daerah Kabupaten/Kota.

Menyangkut penyusunan peraturan perundang-undangan di Indonesia, UU No. 12 Tahun 2011 mengharuskan pembentuknya memperhatikan jenis, hierarki, dan muatan materi yang diatur di dalamnya. Pembentukan norma hukum di Indonesia harus berdasar dan bersumber pada norma hukum yang lebih tinggi. Mengingat sistem norma hukum Indonesia membentuk bangunan piramida, norma hukum yang berlaku berada dalam suatu sistem yang berjenjang-jenjang, berlapis-lapis, sekaligus berkelompokkelompok. Dalam arti, bahwa norma hukum tersebut berlaku, bersumber, dan berdasar pada norma hukum yang lebih tinggi, dan norma hukum yang lebih tinggi berlaku, bersumber dan berdasar pada norma hukum yang lebih tinggi pula, demikian seterusnya (Lailam, 2014). Jadi pada prinsipnya, bahwa keberlakuan norma hukum yang lebih rendah bersandar pada norma hukum yang lebih tinggi. Tidak diperkenankan membentuk norma hukum yang lebih rendah tetapi berseberangan dengan norma hukum yang lebih tinggi.

Dalam kasus PP No. 57 Tahun 2021 dengan UU No. 12 Tahun 2012 dapat diketahui terjadi konflik norma, terkait muatan wajib kurikulum pendidikan tinggi. PP tersebut secara garis besarnya tidak mencantumkan Pancasila sebagai muatan wajib kurikulum di pendidikan tinggi. Kontras dengan UU No, 12 Tahun 
2012 yang menentukan, bahwa Pancasila masuk menjadi bagian kurikulum wajib di pendidikan tinggi. Seperti yang disebutkan di atas, bahwa pertentangan norma hukum itu dapat diselesaikan dengan jalur yudicial review. Judicial review yang penulis maksud adalah berada pada tataran di bawah undang-undang. Apalagi yudicial review memperoleh pijakan dan landasan yang kuat dalam sistem ketatanegaraan Indonesia berdasarkan UUD 1945. Dalam Pasal 24A (1) UUD 1945 disebutkan, bahwa Mahkamah Agung berwenang mengadili pada tingkat kasasi, menguji peraturan perundang-undangan di bawah undang-undang terhadap undangundang, dan mempunyai wewenang lainnya yang diberikan oleh undang-undang. Pengaturan konstitusional tersebut ditegaskan kembali melalui Pasal 9 ayat (2) UU No. 12 Tahun 2011 yang menyatakan, bahwa "Dalam hal suatu Peraturan Perundang undangan di bawah Undang-Undang diduga bertentangan dengan Undang-Undang, pengujiannya dilakukan oleh Mahkamah Agung”. Berarti jika terjadi konflik antara UU dengan PP, maka dapat diajukan ke Mahkamah Agung untuk diuji secara materil. Mengingat kedudukan PP No. 57 Tahun 2021 tepat berada di bawah UU No. 12 Tahun 2012.

Pengujian peraturan perundang-undangan tidak hanya dilakukan di bawah undang-undang terhadap undang-undang. Pengujian peraturan perundang-undangan juga harus dilakukan ditingkat UUD 1945. Mengingat permasalahan besar dibidang pendidikan muncul di Indonesia sejak disahkannya UU No. 20 Tahun 2003. Tidak dicantumkannya Pancasila dalam kurikulum wajib di pendidikan tinggi dalam UU No. 20 Tahun 2003 mengundang persoalan tersendiri bagi bangsa Indonesia. Tidak jelasnya posisi Pancasila dalam kurikulum sistem pendidikan nasional Indonesia jangan dibiarkan berlarut-larut. Untuk itu, pihak-pihak yang merasa memiliki legal standing sebaiknya mengajukan judicial review or constitusional review ke Mahkamah Konstitusi. Constitutional review digunakan secara umum terhadap 
proses uji konstitusionalitas produk peraturan perundang-undangan yang berada di bawah konstitusi. Tugas constitutional review ini lazimnya dilakukan oleh sebuah lembaga yang secara khusus ditunjuk konstitusi. Untuk kasus di Indonesia, UUD 1945 menyerahkan kewenangan constitusional review kepada sebuah lembaga bernama Mahkamah Konstitusi. Pasal 24C ayat (1) UUD 1945 menyatakan, bahwa "Mahkamah Konstitusi berwenang mengadili pada tingkat pertama dan terakhir yang putusannya bersifat final untuk menguji undang-undang terhadap UndangUndang Dasar, memutus sengketa kewenangan lembaga negara yang kewenangannya diberikan oleh Undang-Undang Dasar, memutus pembubaran partai politik dan memutus perselisihan tentang hasil pemilihan umum".

Selain melalui yudicial review, penyelarasan norma hukum peraturan perundang-undangan antara PP No. 57 Tahun 2021 dengan UU No. 12 Tahun 2012 dapat dilakukan dengan executive review. Pengujian oleh lembaga eksekutif (executive review) dilakukan terhadap peraturan perundang-undangan yang dibentuk oleh lembaga eksekutif sendiri. Jadi PP No. 57 Tahun 2021 adalah produk hukum yang dibuat dan dihasilkan oleh Pemerintah sebagai lembaga eksekutif. PP tersebut mendapat sambutan dan respon yang dingin dari civitas akademika berbagai perguruan tinggi di Indonesia. Sehingga menjadi sebuah kewajaran bila ditemukan muatan materi yang tumpang tindih (overlapping) dengan UU No. 12 Tahun 2012 sebagai peraturan yang lebih tinggi, Pemerintah melalui inisitifnya sendiri dapat melakukan review terhadap PP No. 57 Tahun 2021 terkait muatan wajib kurikulum pendidikan tinggi. Dalam konteks ini, diperkenalkan istilah "control internal" yang dilakukan oleh pihak itu sendiri terhadap produk hukum yang dikeluarkan baik yang berbentuk regeling maupun beschikking. Sasaran objek "executive review" adalah peraturan yang bersifat regeling melaui proses pencabutan atau pembatalan. Pengujian ini dilakukan untuk menjaga peraturan yang 
dibuat pemerintah tetap sinkron atau searah, dan juga konsisten serta adanya kepastian hukum bagi masyarakat (Simatupang, 2019).

Lain daripada itu, dalam sistem hukum di Indonesia dikenal pula istilah political review or legislative review. Legislative review dan executive review adalah upaya yang dapat dilakukan untuk mengubah suatu undang-undang melalui lembaga legislatif berdasarkan fungsi legislasi yang dimilikinya. Bahkan pihak legislatif dapat menciptakan undang-undang baru yang mengatur persoalan sama dengan tujuan menggantikan keberlakuan suatu norma sebelumnya. Legislatif di Indonesia menurut Pasal 20 UUD 1945 adalah DPR dan Presiden. Dua lembaga inilah yang memiliki kompetensi untuk mengajukan, merevisi, mengubah, dan membentuk UU baru. Terkait pengaturan muatan wajib kurikulum dalam UU No. 20 Tahun 2003 khususnya untuk pendidikan tinggi, DPR dan Pemerintah sebenarnya telah menggunakan fungsi legislatifnya. Fungsi Legislatif yang dimaksud adalah dengan membentuk sebuah undang-undang baru yang secara khusus mengatur tentang pendidikan tinggi, yaitu UU No. 12 Tahun 2012. Dalam UU tersebut secara tegas menyebutkan Pancasila sebagai salah satu mata kuliah wajib dalam kurikulum pendidikan tinggi, selain agama, kewarganegaraan, dan bahasa Indonesia.

Menyikapi permasalahan tersebut, pendidikan tinggi tidak perlu risau dan panik secara berlebihan. Mengingat rujukan yang digunakan dalam penyusunan kurikulum di pendidikan tinggi tetaplah mengacu kepada UU No. 12 Tahun 2012. Sebab realitasnya menunjukan terjadi benturan norma terkait PEMBAHASAN wajib kurikulum pendidikan tinggi antara UU No. 12 Tahun 2012 dengan PP No. 57 Tahun 2021. Dalam situasi seperti ini, UU No. 12 Tahun 2012 lah yang harus digunakan perguruan tinggi sebagai parameter dan acuan normatif. Karena kedudukan UU No. 12 Tahun 2012 secara hierarkis jauh lebih tinggi dibandingkan dengan PP No. 57 Tahun 2021. PP tersebut 
hanya berfungsi menjalankan UU sebagaimana mestinya, seperti yang diatur dalam Pasal 5 ayat (2) UUD 1945. Ketika PP yang dibentuk tidak sesuai dengan UU yang berada di atasnya, maka tidak ada keharusan bagi perguruan tinggi untuk mengikutinya. Lagi pula UU No. 12 Tahun 2012 memberikan keleluasaan (otonomi) kepada perguruan tinggi untuk menyusun kurikulumnya sendiri. Bukan hanya secara hierarkis saja, dasar penolakan perguruan tinggi untuk tidak berpedoman pada PP No. 57 Tahun 2021, karena UU yang digunakan sebagai rujukan dalam PP tersebut sama sekali tidak memenuhi asas hukum lex specialis derogat legi generali.

\section{PENUTUP}

Melalui kewenangannya, Presiden Jokowidodo telah menerbitkan PP No. 57 Tahun 2021 tentang Standar Nasional Pendidikan. Tidak berselang lama pasca lahirnya PP tersebut, polemik dan kontroversi pun menyeruak dikalangan civitas akademika. Mereka tidak sepakat dengan PP No. 57 Tahun 2021, karena menghilangkan Pancasila dalam kurikulum pendidikan tinggi. Sikap ketidaksetujuan tersebut bukanlah tanpa didasari alasan yang kuat. Sebab UU No. 12 Tahun 2012 tentang Pendidikan Tinggi pada dasarnya menempatkan Pancasila sebagai muatan wajib kurikulum perguruan tinggi. Adapun dalih Pemerintah tidak memasukan Pancasila dalam PP No. 57 Tahun 2021, karena peraturan tersebut dibuat dan disusun dengan merujuk UU No. 20 Tahun 2003 tentang Sistem Pendidikan Nasional. Disini Pemerintah sangat gegabah atau ceroboh dalam menyusun PP No. 57 Tahun 2021. Pertama, Pemerintah tidak berpegang teguh pada prinsip hukum Asas lex specialis derogat legi generali dalam membentuk PP No. 57 Tahun 2021. Harusnya dalam penyusunan PP No. 57 Tahun 2021 yang mengatur kurikulum pendidikan tinggi bukannya berpedoman pada UU No. 20 Tahun 2003, melainkan berpegangan pada UU No. 12 Tahun 2012. Karena UU No. 20 
Tahun 2003 adalah ketentuan yang bersifat umum dalam pengaturan kurikulum pendidikan tinggi. Berbeda dengan UU No. 12 Tahun 2012 yang memang merupakan peraturan bersifat khusus yang mengatur pendidikan tinggi, termasuk kurikulumnya. Kedua, Di samping tidak taat dengan asas hukum lex specialis derogat legi generali, penyusunan PP No. 57 Tahun 2021 terkait kurikulum wajib pendidikan tinggi juga tidak mengikuti asas hukum Lex Posterior Derogat Legi Prior. Asas ini seharusnya digunakan sebagai dasar dan patokan bagi Pemerintah dalam penyusunan PP No. 57 Tahun 2021 menyangkut muatan wajib kurikulum di pendidikan tinggi. Mengingat UU No. 12 Tahun 2012 adalah norma hukum baru yang memiliki kedudukan sederajat dengan UU No. 20 Tahun 2003 yang merupakan norma hukum lama. Dihapuskannya Pancasila dalam kurikulum pendidikan tinggi menurut PP No. 57 Tahun 2021 paling tidak membuat mahasiswa kehilangan rujukan dalam kehidupan berbangsa dan bernegara. Kebijakan tersebut tanpa disadari telah menjauhkan dan mengasingkan Pancasila dari kehidupan mahasiswa. Implikasinya adalah mahasiswa tidak lagi menganggap penting Pancasila dalam kehidupan bernegara. Bagaimana jadinya bangsa Indonesia, bila Pancasila yang merupakan ideologinya malah berada jauh dengan relung batin mahasiswa. Padahal ke depannya mahasiswa adalah tumpuan bangsa yang berperan melanjutkan estapet kepemimpinan negara di masa depan. Merekalah nantinya yang menduduki jabatan di lembaga eksekutif, legislatif dan yudikatif. Untuk mengatasi persoalan yang muncul akibat PP No. 57 Tahun 2021, penulis mengajukan beberapa solusi, seperti pertama, melalui yudicial review. Dalam kasus PP No. 57 Tahun 2021 dengan UU No. 12 Tahun 2012 dapat diketahui terjadi konflik norma, terkait muatan wajib kurikulum pendidikan tinggi. Berarti jika terjadi konflik antara UU dengan PP, maka dapat diajukan ke Mahkamah Agung untuk diuji secara materil. Mengingat kedudukan PP No. 57 Tahun 2021 tepat berada di bawah UU No. 12 Tahun 2012. Kedua, 
Pengujian peraturan perundang-undangan tidak hanya dilakukan di bawah undang-undang terhadap undang-undang. Pengujian peraturan perundang-undangan juga harus dilakukan ditingkat UUD 1945. Mengingat permasalahan besar dibidang pendidikan muncul di Indonesia sejak disahkannya UU No. 20 Tahun 2003. Ketiga, selain melalui yudicial review, penyelarasan norma hukum peraturan perundang-undangan antara PP No. 57 Tahun 2021 dengan UU No. 12 Tahun 2012 dapat dilakukan dengan executive review. Keempat, Lain daripada itu, dalam sistem hukum di Indonesia dikenal pula istilah political review or legislative review. Legislative review dan executive review adalah upaya yang dapat dilakukan untuk mengubah suatu undang-undang melalui lembaga legislatif berdasarkan fungsi legislasi yang dimilikinya. DPR dan Pemerintah sebenarnya telah mengubah UU No. 20 Tahun 2003 yang mengatur kurikulum pendidikan tinggi dengan UU No. 12 Tahun 2012.

\section{DAFTAR PUSTAKA}

Irfani, Nurfaqih. (2020). Asas Lex Superior, Lex Specialis, Dan Lex Posterior: Pemaknaan, Problematika, Dan Penggunaannya Dalam Penalaran Dan Argumentasi Hukum. Jurnal LEGISLASI INDONESIA. 16 (3), 305-325.

Lailam, Tanto. (2014). Konstruksi Pertentangan norma Hukum Dalam Skema Pengujian Undang-Undang. urnal Konstitusi, 11 (1), 18-42.

Santika, I. G. N. (2019). Presidensialisme Dan Problematika Mekanisme Impeachment Presiden Dan/Atau Wakil Presiden Berdasarkan UUD 1945 Pasca Perubahan (Perspektif Pergulatan Hukum Dan Politik). Jurnal Ilmiah Ilmu Sosial, 5 (1), 23-34 
Santika, I. G. N. (2021). Grand Desain Kebijakan Strategis Pemerintah Dalam Bidang Pendidikan Untuk Menghadapi Revolusi Industri 4.0. Jurnal Education and Development. 9 (2), 369-377. https://doi.org/10.37081/ed.v9i2.2500

Santika, I. G. N. (2020). Menelisik Akar Kegaduhan Bangsa Indonesia Pasca Disetujuinya Hasil Revisi UU KPK Dalam Perspektif Pancasila. Jurnal Ilmiah Ilmu Sosial. 6 (1), 6-36. http://dx.doi.org/10.23887/jiis.v6i1.25001

Santika, I. G. N., Sujana, G., \& Winaya., M. A. (2019). Membangun Kesadaran Integratif Bangsa Indonesia Melalui Refleksi Perjalanan Historis Pancasila Dalam Perspektif Konflik Ideologis. Jurnal Etika Demokrasi (JED). 4 (2), 89-98. https://doi.org/10.26618/jed.v4i2.2391

Santika, I. G. N., Rindawan, I. K., \& Sujana, I. G. (2019). Memperkuat Pancasila Melalui Pergub No. 79 Tahun 2018 Dalam Menanggulangi Pengikisan Budaya Di Era Revolusi Industri 4.0.. Prosiding Seminar Nasional Inobali 2019, 79, 981-990

Santika, I. G. N (2020). Menggali dan Menemukan Roh Pancasila Secara Kontekstual. Jawa Tengah: Lakeisha.

Santika, I. G. N (2021). Pendidikan Kewarganegaraan (Studi Komparatif Konstitusi Dengan UUD 1945). Jawa Tengah: Lakeisha.

Simatupang, Taufik H. (2019). Mendudukkan Konsep Executive Review Dalam Sistem Hukum Ketatanegaraan Indonesia (Establishing the Concept of The Executive Review in The Indonesian Constitutional Law System). Jurnal Penelitian Hukum DE JURE, 19 (2), 217-230. 
Putri, Tri Endang Sungkowo, Pentingnya Pendidikan Pancasila Sebagai Materi Pembelajaran Di Pendidikan tinggi (Studi Kasus Di Stt Malang), SINTEKS, 1 (2),

\section{Peraturan Perundang-Undangan.}

Undang-Undang Dasar Negara Republik Indonesia Tahun 1945

Ketetapan MPR Nomor XX Tahun 1966 Tentang Memorandum DPR-GR Mengenai Sumber Tertib Hukum Republik Indonesia Dan Tata Urutan Peraturan Perundang-Undangan Republik Indonesia.

Ketetapan MPR No. III Tahun 2000 Tentang Sumber Hukum Dan Tata Urutan Peraturan Perundang-Undangan.

Undang-Undang Nomor 20 Tahun 2003 Tentang Sistem Pendidikan Nasional.

Undang-Undang Nomor 12 Tahun 2012 Tentang Pendidikan Tinggi.

Undang-Undang Nomor 10 Tahun 2004 Tentang Pembentukan Peraturan Perundang-Undangan.

Undang-Undang Nomor 12 Tahun 2011 Tentang Pembentukan Peraturan Perundang-Undangan.

Peraturan Pemerintah Nomor 57 Tahun 2021 Tentang Standar Nasional Pendidikan. 


\title{
PENGUATAN MODAL SOSIAL SUBAK DALAM PELESTARIAN MILAI-NILAI PANCASILA
}

\author{
Gede Sedana
}

Fakultas Pertanian, Universitas Dwijendra gedesedana@gmail.com

\section{PENDAHULUAN}

Pembangunan pertanian memiliki peranan yang sangat penting di dalam pemangunan ekonomi di negara-negara yang sedang berkembang termasuk di Indonesia. Sektor pertanian berkembang dari sistem pertanian tradisional sampai pada pertanian modern. Pertanian tradisional sering dilandasi oleh nilainilai budaya dan nilai sosial dari masyarakat petani saat itu. Hingga saat ini, sistem pertanian tradisional masih dilakukan oleh kelompok petani di berbagai negara terutama di negara agraris. Salah satu bagian dari system pertanian yang dikenal adalah sistem irigasi baik irigasi teknik maupun non-teknis. Secara umum, irigasi merupakan bentuk aplikasi pengelolaan air yang dimanfaatkan untuk kegiatan pertanian di lahan sawah dan nonsawah, dimana para petani membuat dan membangun sistem sederhana (saat terdahulu) guna membendung air yang terdapat di tingkat sumber seperti sungai, mata air, jurang.

Pengelolaan irigasi pertanian merupakan suatu kegiatan dalam suatu sistem yang dikategorikan sebagai fenomena yang 
kompleks (Wibisono, 2013). Sistem irigasi ini memiliki manfaat untuk kebutuhan sosial juga yang dicirikan dengan adanya integrasi internal dan adaptasi terhadap lingkungan eksternal (Raversteijn dkk., 2011). Pengelolaan irigasi secara konvensional atau tradisional sering dipandang sebagai sistem yang kurang efisien, Namun, beberapa peneliti juga meyakini bahwa pengelolaan sistem irigasi tradisional memiliki keefektifan baik dari sisi teknis maupun non-teknis (Windia, 2006, Sedana, et al 2014; Roth and Sedana, 2015).

Di Indonesia, kelembagaan air irigasi berkembang dari kegiatan tradisi masyarakat setempat yaitu melalui kelembagaan irigasi. Eksistensi kelembagaan tersebut dipengaruhi oleh ciri geografis lokal, aktivitas produksi pertanian, dan intervensi pemerintah (Saptana, et al 2001). Salah satu sistem irigasi tradisional yang sangat dikenal di dunia adalah subak. Nilai-nilai tradisi yang telah diimplementasi oleh subak sejak ribuan tahun lalu juga menjadi salah satu inspirasi bagi pendiri negara Indonesia yang diwujudkan dalam nilai-nilai Pancasila sebagai dasar negara. Sebagai ideologi dasar bagi negara Indonesia, Pancasila menjadi acuan dan pedoman mengenai perilaku menjadi warga negara yang baik karena nilai-nilainya mengandung cara berfikir dan bertindak di dalam kehidupan berbangsa dan bernegara (Damanhuri et al, 2016; Eddy, 2018).

Pancasila sebagai dasar negara memiliki beberapa fungsi penting, di antaranya adalah sebagai berikut: (i) pedoman hidup; (ii) perangkat tata nilai; (iii) jiwa bangsa; (iv) jati diri bangsa; (v) alat pemersatu bangsa; dan (vi) ketahanan bangsa (Krisnamurti et al, 2020). Perkembangan globalisasi, modernisasi dan dinamika masyakarat yang terjadi saat ini memberikan berbagai implikasi terhadap eksistensi nilai-nilai Pancasila pada berbagai kehidupan termasuk dalam sistem subak. Pengakuan badan dunia yaitu UNESCO (United Nations Educational, Scientific and Cultural Organization) terhadap nilai-nilai luhur yang terkandung dalam 
subak telah diformalkan sejak tahun 2012 melalui penetapan subak sebagai world cultural heritage atau Warisan Budaya Dunia (Lestari, et al, 2015; Windia dan Wiguna, 2013).

Hal ini berarti bahwa nilai-nilai yang terkandung dalam sistem subak yang telah terbentuk lebih dari 1.000 tahun yang lalu masih menunjukkan eksistensinya. Nilai-nilai yang terkandung dalam sistem subak merupakan modal sosial bagi lembaga subak di dalam penyelenggaraan berbagai kegiatan sosial, pertanian, keagamaan dan ekonomis. Modal sosial yang masih kuat pada sistem subak memiliki keterkaitan dengan nilai-nilai Pancasila di dalam kehidupan sehari-hari. Oleh karena itu, tulisan ini bertujuan untuk menemukenali modal sosial subak berkenaan dengan nilainilai Pancasila yang diterapkan di dalam pembangunan pertanian, khususnya di lahan sawah.

\section{PEMBAHASAN}

\subsection{Penerapan Nilai-Nilai Pancasila Dalam Sistem Subak}

Pada hakikatnya pembangunan nasional merupakan pembangunan manusia Indonesia seutuhnya dan seluruhnya yang didasarkan pada Pancasila. Pembangunan sector pertanian sebagai integral dari pembangunan nasional memiliki tujuan untuk mewujudkan ketahanan pangan dan kedaulatan pangan. Kondisi ini menjadi sangat rasional karena Indonesia merupakan negara agraris dimana sebagian besar penduduknya memiliki mata pencaharian pada sektor pertanian dalam arti luas. Penyelenggaraan pembangunan pertanian tidak hanya berkenaan dengan aspek ekonomi tetapi juga menyangkut aspek teknis, sosial dan budaya, tradisi, keyakinan, dan keagamaan di dalam suatu kelembagaan pertanian.

Secara tegas, Pancasila dan UUD 1945 telah mengamanatkan kepada negara untuk memiliki kewajiban dan tanggung jawab untuk melindungi segenap bangsa Indonesia dan 
memajukan kesejahteraan umum, mencerdaskan kehidupan bangsa serta mewujudkan keadilan sosial bagi seluruh rakyat Indonesia. Demikian pula halnya pada sektor pertanian, negara memiliki kewajiban serta tanggung jawab untuk meningkatkan kesejahteraan para petani beserta keluarganya. Pemerintah dalam beberapa dekade terakhir telah melakukan berbagai kewajibannya di dalam membangun pertanian termasuk memberikan perlindungan kepada petani.

Salah satu kewajiban tersebut telah dituangkan di dalam Undang-Undang Republik Indonesia Nomor 19 tahun 2013 tentang Perlindungan dan Perberdayaan Petani. Perlindungan petani yang dimaksudkan adalah segala upaya untuk membantu petani dalam menghadapi permasalahan kesulitan memperoleh prasarana dan sarana produksi, kepastian usaha, risiko harga, kegagalan panen, praktik ekonomi biaya tinggi, dan perubahan iklim. Sedangkan, pemberdayaan petani meruapakan segala upaya untuk meningkatkan kemampuan petani di dalam melaksanakan pengelolaan usahatani yang lebih baik melalui pendidikan dan pelatihan, penyuluhan dan pendampingan, pengembangan sistem dan sarana pemasaran hasil pertanian, konsolidasi dan jaminan luasan lahan pertanian, kemudahan akses ilmu pengetahuan, teknologi dan informasi, serta penguatan kelembagaan petani.

\subsection{Sistem Subak dan Modal Sosial}

Pertanian tanaman pangan adalah salah satu subsektor pada sektor pertanian yang masih memiliki peranan sangat penting di dalam pembangunan baik di daerah maupun di tingkat nasional. Ketahanan pangan bagi negara menjadikan kondisi bangsa yang semakin kuat di dalam mendukung dan menciptakan ketahanan nasional. Para petani di Indonesia merupakan produsen pangan, khususnya padi dan palawija, dimana kondisi ekonominya masih relatif rendah karena adanya berbagai masalah dan tantangan baik secara internal maupun eksternal. 
Pengelolaan pertanian tanaman pangan di Provinsi Bali telah dilakukan sejak dahulu melalui organisasi petani dengan sitem irigasi yang tradisional dan dikenal dengan sebutan subak. Menurut Perda Provinsi Bali Nomor 9 tahun 2012 tentang Subak, subak didefinisikan sebagai suatu organisasi petani pengelola air irigasi yang bersifat sosio teknis religius, dalam suatu kawasan sawah tertentu, mendapatkan air irigasi dari suatu sumber tertentu, mengelola Pura Subak, dan bersifat otonom. Disebutkan pula bahwa lembaga subak sebagai bagian dari budaya Bali merupakan suatu organisasi sosial yang memiliki potensi untuk meningkatkan kesejahteraan masyarakat melalui kegiatan utamanya yang mengelola pemanfaatan air irigasi untuk usahatani di lahan sawah. Oleh karena itu, subak perlu diakui dan dihormati keberadaannya beserta hak-hak tradisionalnya.

Subak-subak di Bali memiliki asas Pancasila, UndangUndang Dasar Negara Republik Indonesia Tahun 1945 sebagai landasan konstitusionalnya, serta konsep Tri Hita Karana yang dijiwai oleh Agama Hindu. Beberapa tujuan subak yang diatur di dalam Perda Nomor 9 tahun 2012 adalah mencakup: (i) memelihara dan melestarikan organisasi subak; mensejahterakan kehidupan petani; (iii) mengatur pengairan dan tata tanaman; (iv) melindungi dan mengayomi petani; dan (v) memelihara serta memperbaiki saluran air ke sawah.

Sistem subak-subak di Bali memiliki filosofi Tri Hita Karana (THK) yang dijadikan landasan di dalam pengelolaan irigasi dan pertanian. Filosofi ini memberikan makna yang kuat terhadap keharmonisan, keseimbangan di dalam kebersamaan antara manusia, alam dan Yang Maha Kuasa (Tuhan). Perwujudan filosofi THK (Tri Hita Karana) yang terdiri dari Parhyangan, Pawongan, dan Palemahan memiliki nilai-nilai universal tentang kehidupan yang menggambarkan pola-pola hubungan keharmonisan dan keseimbangan untuk mewujudkan tujuan 
organisasinya (Windia, 2006; Suwarnata, 2011). Hubungan di antara ketiga komponen THK dapat dilihat pada Gambar 1.

Gambar 1

Komponen tri hita karana

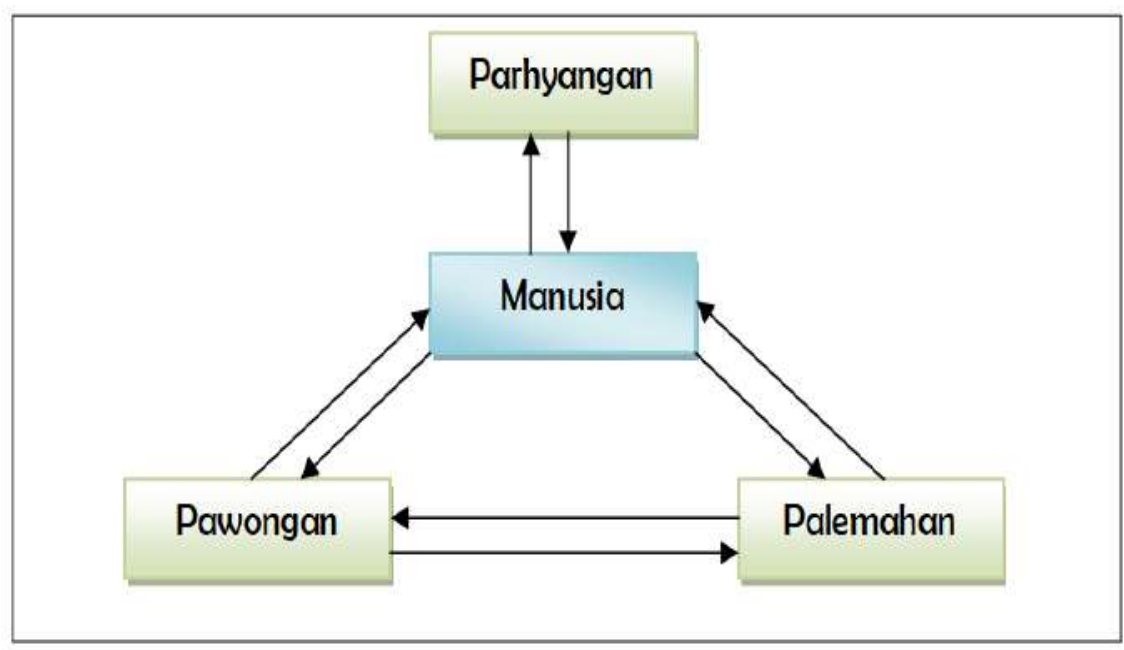

Gambar 1 memberikan gambaran secara umum bahwa Parhyangan adalah hubungan yang harmonis antara manusia (petani) dengan Tuhan sebagai Yang Maha Kuasa. Para petani senantiasa mengekspresikan rasa syukurnya kepada Tuhan Yang Maha Esa atas berbagai rahmatNya yang telah diberikan dan akan diberikan dalam pengelolaan usahataninya. Pawongan merupakan keharmonisan hubungan antara manusia dengan sesama, yaitu antar petani, petani dengan pengurus subak, dan petani dengan pihak luar termasuk pemerintah. Hubungan ini terjadi dalam bentuk interaksi sosial yang intensif dalam berbagai kegiatan yang berkenaan pertanian, irigasi, lingkungan dan ritual keagamaan. Sementara itu, palemahan diartikan sebagai suatu hubungan yang harmonis antara manusia (para 
petani) dengan lingkungan alam sekitarnya. (Windia, et al 2015).

Sebagai organisasi irigasi tradisional, subak mempunyai beberapa fungsi, yaitu: (i) membantu pemerintah dalam meningkatkan pencapaian tujuan pembangunan pertanian; (ii) melaksanakan aktivitas di dasarkan pada hukum adat dan adat istiadat dalam subak; (iii) menetapkan peraturan internal (awigawig) sebagai suatu kesepakatan atau konsensus untuk mengatur penyelenggaraan kegiatan sosial, keagamaan, irigasi dan pertanian; (iv) membina dan melestarikan nilai-nilai agama dan adatistiadat Bali serta tetap menjaga persatuan dan kesatuan anggota berdasarkan paras paros segilik seguluk selunglung sebayantaka; (v) menjaga, memelihara, mengembangkan dan memanfaatkan kekayaan subak dan prasarana-prasarana irigasi lainnya guna menjamin kelancaran tertibnya irigasi dalam mewujudkan kesejahteraan masyarakat; (vi) mengembangkan kemampuan krama subak untuk meningkatkan produktifitas, pendapatan dan kesejahteraan petani; dan (vii) menjaga kelestarian wilayah subak dan lingkungannya dalam rangka pertanian berkelanjutan (Perda No.9/2012).

Nilai-nilai yang telah berkembang dalam organisasi subak merupakan komponen dari modal sosial yang memiliki manfaat untuk memperkuat eksistensi subak. Modal sosial yang dimaksud atau social capital mempunyai peranan yang sangat penting dalam pembangunan di masyarakat karena modal sosial merupakan energi kolektif suatu masyarakat yang bermanfaat untuk mengatasi persoalan bersama dan menjadi sumber motivasi di dalam pencapaian kemajuan ekonomi (Flassy, et al., 2009). Modal sosial meliputi empat komponen yaitu norms, reciprocity, trust, and network yang mempunyai pengaruh kuat terhadap pola perilaku kehidupan dan kerjasama antar warga masyarakat untuk mewujudkan tujuan yang diinginkan dan dapat mengakomodasi berbagai kepentingan individu untuk 
penyelenggaraan kerjasama secara kolektif. (Subejo, 2004; Mudarta, 2009). Selanjutnya, disebutkan juga bahwa Social capital is the trust, reciprocity and mutuality that inhere to social relationships. It accumulates to the extent that members of different social groups can maintain respect for differences and learn to cooperate, especially beyond the family and clan. Trust and mutuality in the sociological sense are often identified as a "moral resource (Carrol, 2001).

\subsection{Nilai-nilai Pancasila pada Sistem Subak}

Pancasila merupakan dasar negara yang sekaligus menjadi landasan, pedoman dan sekaligus mengontrol setiap pikiran, sikap, dan perilaku manusia dalam kehidupan (Octavian, 2018). Nilainilai Pancasila terlihat pada nilai-nilai yang diimplementasikan dalam aktivitas pertanian, termasuk di dalam kehidupan para petani di dalam sistem subak. Sesuai dengan sifatnya yang sosio-agrarisreligius, subak-subak di Bali memiliki nilai-nilai yang terkandung di dalam Pancasila dan di antara satu nilai dengan nilai lainnya saling berkaitan secara kuat. Seperti telah disebutkan di atas bahwa filosofi subak-subak yang sangat terkenal adalah Tri Hita Karana yang juga telah menjadi jiwa dari para petani anggotanya di dalam beraktivitas dalam bidang irigasi dan pertanian dan kegiatan pendukungnya.

\subsubsection{Nilai Ketuhanan Yang Maha Esa}

Sila ketuhanan yang mahaesa memberikan makna bahwa Indonesia merupakan suatu negara yang sangat percaya dengan adanya Tuhan. Selain itu, Indonesia juga mengakui keberagaman agama dan kepercayaan yang menjunjung tinggi nilai ketuhanan serta menjadikannya pedoman paling esensial bagi setiap umatnya di dalam kehidupan sehari-harinya. Dalam penyelenggaraan kegiatan pertanian dan irigasi pada lembaga sistem subak, nilai ketuhanan sangat kental bagi seluruh petani sebagai anggota subak. 
Mereka memiliki keyakinan dan kepercayaan yang kuat terhadap Hyang Widi Wasa/Tuhan Yang Mahaesa. Nilai ketuhanan ini terkandung pada komponen Parhyangan sebagai salah satu dari komponen THK.

Pengejawantahan nilai ketuhanan dalam sistem subak terlihat pada artefak di dalam setiap subak, di antaranya adalah bangunan pura atau tempat suci untuk pemujaan Tuhan. Keberadaan tempat suci untuk kegiatan irigasi dan pertanian berada pada level individu petani, level subak, level antar subak dan bahkan sampai ke tingkat provinsi. Pemilikan bangunan suci bahkan menjadi salah satu syarat terbentuknya subak. Oleh karena itu, nilai-nilai ketuhanan dalam Pancasila telah sejak lama dipahami dan diimplementasikan oleh para petani anggota subak hingga saat ini.

Pada level petani, setiap petani memiliki satu tempat suci kecil yang dibangun di bagian hulu dari lahan sawahnya atau tepatnya di saluran intake (pengalapan) ke petak sawahnya. Bentuk bangunannya bervariasi termasuk juga bahan yang digunakannya. Dimana tergantung pada kemapuan ekonomi dari setiap petani. Pada bangunan suci ini, setiap petani (juga istrinya) melakukan pemujaan dengan mempersembahkan sesaji (istilah lokalnya adalah banten atau canang) pada hari-hari tertentu sesuai dengan Kalendar Bali dan sesuai dengan tahapan pengelolaan usahatani padi di lahan sawahnya. Para petani memohon keselamatan dan kesejahteraan kepada Tuhan melalui pengelolaan usahataninya yang produktif dan hasilnya memberikan keuntungan ekonomis. Hasil penelitian Windia, et al (2015) menunjukkan bahwa sedikitnya terdapat 15 kali kegiatan ritual keagamaan yang dilakukan oleh petani sepanjang satu musim tanam tanaman padi.

Pada level subak, beberapa bangunan suci yang dimiliki oleh subak adalah Pura Bedugul, Pura Ulun Subak, Pura Ulun Suwi dan lain sebagainya, tergantung pada luasan areral subak dan 
sistem budaya serta adat/tradisi yang telah ada sebelumnya. Pada bangunan-bangunan suci tersebut, penyelenggaraan ritual keagamaan dilakukan oleh para petani secara bersama-sama melalui koordinasi pekaseh (ketua subak). Berbagai rangkaian upacara keagamaan dilakukan di bangunan suci tersebut disebut sesuai dengan hari-hari baik pada tahapan pengelolaan usahatani padi dan juga odalan setiap enam bulan atau 210 hari (satu bulan Bali setara dengan 35 hari).

Pada level antar subak, beberapa bangunan suci yang menjadi pemujaan subak-subak dapat berada di tingkat kabupaten dan juga provinsi. Sejak ribuan tahun yang lalu, subak-subak di Bali menyelenggarakan kegiatan ritual keagamaan di Pura Ulun Danu, yaitu bangunan suci yang terdapat di kawasan danau. Di Bali terdapat empat danau, yaitu Danau Beratan, Danau Buyan, Danau Tamblingan dan Danau Batur. Ini berarti bahwa terdapat empat Pura Ulun Danu di Bali. Secara tradisi yang diturunkan, pada setiap Pura Ulun Danu telah menjadi temapt pemujaan bagi subak-subak yang merasa bahwa air irigasinya bersumber dari salah satu danau tersebut.

Pada Subak Tegalinggah dan Subak Pegayaman di Kabupaten Buleleng menunjukkan adanya keberagaman keyakinan atau agama para petani anggotanya, yaitu Agama Isalam dan Hindu. Sehubungan dengan implementasi nilai-nilai Pancasila, subak telah mampu melakukan pembinaan kerukunan hidup di antara petani anggota subaknya yang memiliki agama dan kepercayaan berbeda. Mereka sangat meyakini bahwa agama dan kepercayaan terhadap Tuhan Yang Maha Esa yang dianutnya merupakan hak privat tentang hubungan pribadi antara dirinya dengan Tuhan Yang Mahaesa. Penyelenggaraan ritual keagamaan dilakukan secara terpisah pada bangunan suci yang berbeda pula. Ini berarti bahwa para petani yang berbeda agama dan kepercayaan telah menunjukkan sikap yang saling menghormati keyakinan 
masing-masing di dalam menjalankan ibadahnya. Kekuatan nilai ketuhanan pada para petani menjadi salah satu modal sosial bagi subak untuk menjaga keutuhan organisasinya di dalam penyelenggaraan kegiatan pertanian dan irigasi.

\subsubsection{Nilai Kemanusiaan yang Adil dan Beradab}

Sila kemanusiaan yang adil dan beradab memiliki simbol rantai yang terdiri dari gfelang-gelang kecil dan tersambung satu dengan yang lainnya secara utuh memberikan makna adanya hubungan yang sangat erat di antara sesama manusia. Pada sistem subak, hubungan antar petani telah diatur melalui peraturan internal atau awig-awig yang dibuat dan disusun berdasarkan pada kesepakatan dan konsensus seluruh anggota subak. Tidak perbedaan perlakuan yang signifikan terhadap seluruh anggota karena setiap anggota telah dibebankan kewajiban-kewajiban dan diberikan hak-haknya sesuai dengan kewajiban tersebut. Kewajiban yang dimiliki oleh anggota subak didasarkan pada alokasi air irigasi yang diterimanya. Hak dan kewajiban anggota subak diatur berdasarkan pada pengalaman-pengalaman yang sangat panjang, sepoerti berkenaan dengan luas lahan sawah, lokasi lahan sawah, sifat fisik tanah (berpasir, liat atau lempung) dan berbagai pertimbangan lainnya.

Pada sistem subak, nilai-nilai persamaan hak dan kewajiban tidak didasarkan pada perbedaan agama atau keyakinan, asal anggota subak, kedudukannya di masyarakat. Namun, keanggotaan subak secara umum dibagi menjadi tiga kategori berdasarkan pada kesepakatan bersama. Ketiga kategori tersebut adalah anggota aktif, anggota pasif dan anggota kehormatan. Anggota aktif adalah petani yang setiap saat selalu mengikuti kegiatan persubakan, sedangkan mereka yang tidak aktif dan memberikan kompensasi atau kontribusi kepada subak tergolong anggota pasif. Anggota kehormatan biasanya diberikan kepada 
petani yang memiliki jasa atau menjadi pemuka agama di dalam organisasi subak.

Organisasi subak melalui koordinasi pekaseh selalu mengutamakan rasa kebersamaan, saling menghargai, tenggang rasa di antara para petani anggota subak. Salah satu aktivitas yang menunjukkan kebersamaan dan tenggang rasa tersebut adalah pada system pinjam-meminjam air irigasi, terutama saat musim kemarau. Keterbatasan air irigasi dapat diatur melalui system rotasi dan juga staggering sehingga petani tidak mengalami kekurangan air irigasi dan mengakibatkan gagal panen. Ini berarti bahwa nilainilai kemanusiaan yang adil dan beradab telah ada dan diimplementasikan dalam kegiatan persubakan sejak lama hingga saat ini. Nilai kemanusian yang ditunjukan pada subak-subak adalah bertahannya sifat tolong-menolong dan kegotongroyongannya. Sifat-sifat para petani tersebut merupakan modal sosial di dalam subak dan menjadikan interaksi antar petani semakin baik dan menjadi kekuatan bagi subak di dalam membangun dan mengembangkan pengelolaan usahatani di lahan sawahnya.

Ini berarti bahwa para petani anggota subak memiliki mutual trust atau saling percaya di antara mereka sehingga menjadi modal sosial yang memudahkan bagi pengurus subak dan pihak luar, seperti pemerintah dan lembaga lainnya untuk melakukan kegiatan bersama (Sedana, et al 2014). Kolaborasi dan kemitraan di antara subak dengan institusi pemerintah atau non-pemerintah berjalan dengan lancar sebagai efek dari kuatnya modal sosial subak. Misalnya implementasi program intensifikasi khusus pada usahatani padi telah berjalan secara baik, yaitu peningkatan produktivitas tanaman dan lahan. 


\subsubsection{Nilai Persatuan Indonesia}

Sila ketiga dilambangkan dengan simbol pohon beringin yang memiliki makna nilai kesatuan dan persatuan harus dijunjung tinggi oleh setiap warga negara Indonesia. Perbedaan di antara warga negara tidak menjadi hambatan atau masalah untuk mewujudkan tujuan pembangunan. Selain itu, sila ini juga mengandung makna nasionalisme. Pada sistem subak, nilai persatuan ini yang ditunjukan adalah adanya saling membantu (tolong-menolong) dan bergotong royong di antara para petani untuk menjamin kebersamaan dan persatuan di dalam berorganisasi. Berdasarkan pada awig-awig yang telah disepakati, para petani di dalam organisasi subak telah menunjukkan adanya interaksi sosial yang sangat akomodatif dan adaptif. Awig-awig subak merupakan bagian dari modal sosial subak yang memiliki fungsi untuk mengatur segala aktivitas pertanian dan irigasi di dalam sistem subak. Kekuatan awig-awig sebagai modal social disebabkan karena didalamnya mengatur segala sesuatu yang wajib dilakukan dan yang dilarang termasuk dengan penerapan sanksinya jika terjadi pelanggaran.

Pada setiap subak di Bali, para petani memiliki semangat gotong-royong yang masih tinggi dalam melakukan kegiatankegiatan persubakan. Kegiatan gotong royong yang sering dijumpai adalah pemeliharaan dan perbaikan jaringan irigasi. Petani anggota subak memiliki tingkat respon yang tinggi jika terjadi kerusakan saluran irigasi dan bangunan irigasi, sehingga mereka segera melakukan perbaikan secara gotong royong. Bentuk gotong royong dalam system subak adalah kontribusi tenaga kerja, material dan atau uang tunai. Pada kegiatan ritual keagamaan di tingkat subak juga memerlukan kegotongroyongan para petani termasuk wanita tani (istri petani). Perlu dicatat bahwa salah satu alat pemersatu organisasi subak adalah kegiatan ritual keagamaan dan bangunan suci yang dimilikinya. fisik dan kegiatan ritual subak. Ritual subak 
merupakan unsur pemersatu para anggotanya sehingga subak menjadi organisasi yang kuat dan tangguh.

\subsubsection{Nilai Kerakyatan yang dipimpin oleh hikmat kebijaksanaan dalam Permusyawaratan/Perwakilan}

Sila ke-4 ini memiliki makna bahwa pemerintahan yang diselenggarakan di Indonesia memiliki prinsip dari rakyat, oleh rakyat, dan untuk rakyat. Selain itu, sila ini juga memberikan arti secara eksplisit adanya musyawarah mufakat melalui lembagalembaga perwakilan sebagai suatu cara pengambilan keputusan. Atau dengan kata lain, paham demokrasi menjadi dasar bagi masyarakat untuk mengambil keputusan dalam rangka pencapaian tujuan.

Pada tingkat subak, pengambilan keputusan selalu dilakukan secara musyawarah mufakat dari seluruh anggotanya. Prinsip mendasar yang digunakan di dalam pengambilan keputusan adalah konsensus anggota subak. Sistem perwakilan juga dilakukan pada subak jika jumlah anggota subak adalah relatif besar karena ukuran areal sawahnyanya juga relatif luas. Subak-subak yang memiliki luas dan anggota besar biasanya dibagi menjadi beberapa sub-subak yang disebut dengan istilah tempek, banjaran atau lanyahan. Struktur organisasi subak secara umum dapat dilihat pada Gambar 2.

Pada masing-masing tempek diketuai oleh kelihan tempek dan bertanggung jawab kepada kelihan subak atau pekaseh. Berkenaan dengan sistem perwakilan, kelihan tempek menjadi perwakilan anggota tempeknya di dalam pertemuan-pertemuan tertentu. Beberapa pengambilan keputusan yang telah ditetapkan melalui musyawarah mufakat dalam subak-subak di antaranya adalah: (i) pola tanam; (ii) distribusi dan alokasi air irigasi; (iii) jadwal tanam; (iv) pilihan varietas padi; dan (v) penyelenggaraan ritual keagamaan. Proses dan cara pengambilan keputusan yang 
sangat sederhana dalam lembaga subak merupakan bagian dari modal sosial yang kuat di dalam menjamin kelanggengan organisasi melalui penciptaan suasana yang damai, kondusif bagi para petani anggota.

Gambar 2

Struktur organisasi subak

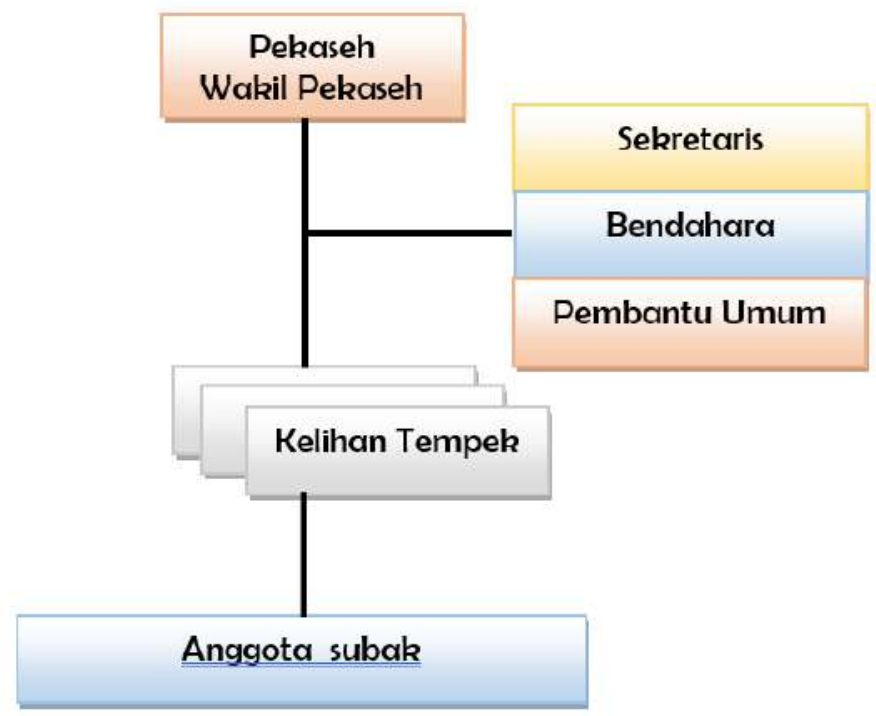

Pada kegiatan ekonomi di tingkat subak juga dilakukan melalui kesepakatan anggota subak. Misalnya, dalam pembentukan koperasi tani seperti di Subak Guama, kegiatan simpan-pinjam, penggunaan dana-dana bantuan, penentuan kontribusi atau iuran para anggota dan aktivitas bisnis lainnya (Sedana, 2020). Kondisi ini memberikan indikasi bahwa modal sosial subak memberikan dukungan yang kuat untuk terselenggaranya kegiatan-kegiatan ekonomis di tingkat subak, dan memberikan manfaat bagi para anggotanya. Oleh karena itu, nilai-nilai modal sosial di tingkat subak sejalan dengan makna yang terkandung dalam sila keempat 
Pancasila. Beberapa nilai tersebut adalah (i) tidak boleh memaksakan kehendak kepada orang lain karena mengutamakan musyawarah mufakat dalam mengambil keputusan untuk kepentingan bersama yang dijiwai oleh semangat kekeluargaan; (iii) menghormati dan menjunjung tinggi setiap keputusan yang dicapai sebagai hasil musyawarah; dan (v) memberikan kepercayaan kepada wakil-wakil yang dipercayai untuk melaksanakan pemusyawaratan.

\subsubsection{Nilai Keadilan Sosial Bagi seluruh Rakyat Indonesia}

Sila kelima Pancasila memiliki makna sebagai dasar dan juga tujuan yaitu terwujudnya kondisi masyarakat Indonesia yang adil dan makmur secara lahiriah dan batiniah. Pada hakekatnya, keadilan merupakan suatu nilai yang sangat mendasar bagi warga masyarakat Indonesia. Beberapa hal yang terkait dengan nilai keadilan sosial ini adalah: (i) mengembangkan perbuatan yang luhur, yang mencerminkan sikap dan suasana kekeluargaan dan kegotong-royongan; (ii) mengembangkan sikap adil terhadap sesama; (iii) menjaga keseimbangan antara hak dan kewajiban; (iv) menghormati hak orang lain; dan (v) suka memberi pertolongan kepada orang lain agar dapat berdiri sendiri. Tidak menggunakan hak milik untuk usaha-usaha yang bersifat pemerasan terhadap orang lain (Raditya, 2020).

Nilai-nilai keadilan yang telah dilakukan pada organisasi subak di Bali adalah distribusi dan alokasi air irigasi. Subak memiliki Teknik atau cara tradisional di dalam menentukan alokasi air irigasi, yaitu menggunakan sistem tektek, nyari, depuk dan sebutan lainnya. Cara tradisional ini diterapkan melalui pengalaman subak yang telah teruji dan dirasakan sangat adil oleh para petani anggotanya. Sistem tektek/depuk tidak harus memberikan alokasi air irigasi dalam jumlah yang sama untuk petani yang memiliki luas sawah sama. Artinya bahwa jika Petani A memiliki luas sama dengan Petani B belum tentu mereka 
memiliki hak sama terhadap alokasi air irigasinya. Nilai keadilan di subak didasarkan pada lokasi sawah, sifat tanah, kewajiban ataua ayahan sebelumnya selain luas areal sawah. Dengan cara tradisional ini para petani merasakan adanya keseimbangan antara hak dan kewajiban di dalam berbagai aktivitas persubakan. Penerapan nilai-nilai keadilan di tingkat subak bertujuan untuk mewujudkan tercapainya peningkatan produktivitas lahan dan tanaman, perbaikan kualitas produk guna memberikan peningkatan pendapatan bagi para petani.

Sistem tektek/depuk/nyari yang diterapkan pada subaksubak berkenaan dengan alokasi air irigasi tidak terlepas dari kewajiban yang dibebankan kepada para petani. Semakin besar kewajiban yang dibebankan, maka semakin tinggi juga hak yang diperoleh oleh para petani. Bagi subak, sistem alokasi air ini menjadi modal sosial untuk menjamin ketersediaan air irigasi di setiap musim (hujan dan kemarau) sehingga pengelolaan usahatani dapat berjalan sesuai dengan kesepakatan yang telah diambil sebelum musim tanam.

\section{PENUTUP}

Subak merupakan salah satu sistem irigasi tradisional yang sangat dikenal di dunia dan bahkan telah dijadikan warisan budaya dunia. Nilai-nilai tradisi subak sebagai modal social telah ada dan dilaksanakan sejak ribuan tahun lalu dan sejalan dengan nilai-nilai Pancasila sebagai dasar negara. Pancasila sebagai ideologi negara menjadi acuan dan pedoman berperilaku menjadi warga negara. Tri Hita Karana sebagai filosofi subak telah menjadikan para petani anggota subak masih kuat mempertahankan nilai-nilai tradisinya dan juga nilai-nilai Pancasila di dalam kegiatan persubakan, seperti irigasi dan pertanian. 
Modal sosial subak memiliki peranan yang sangat penting di dalam membangun pertanian dan penyelenggaraan berbagai kegiatan yang dilandasi oleh keseimbangan, keharmonisan pola interaksi di antara ketiga elemen tri hita karana, yaitu parhyangan, pawongan dan palemahan. Oleh karena itu, nilai-nilai Pancasila telah menjadi pedoman bagi petani anggota subak di dalam beraktivitas seiring dengan pelestarian nilai-nilai modal sosial subak.

\section{DAFTAR PUSTAKA}

Ashrama, B.2005. Implementasi Konsep Tri Hita Karana pada Beberapa Hotel di Bali, Tesis program MM-Unud, Denpasar.

Carrol, TF. 2001. Social Capital, Local Capacity Building, and Poverty Reduction. Michigan: Michigan University Press. Damanhuri, Wika Hardika L., Febrian Alwan B. , Ikman Nur Rahman. 2016. Implementasi Nilai-Nilai Pancasila Sebagai Upaya Pembangunan Karakter Bangsa (Studi Kasus di Kampung Pancasila Desa Tanjung Sari Kecamatan Pabuaran Kabupaten Serang. Untirta Civic Education Journal, Vol. 1, No. 2,: 185-198.

Eddy, I W.T. 2018. Aktualisasi Nilai Pancasila dalam Kehidupan

Berbangsa dan Bernegara. Dharmasmrti, 1:116-123.

Flassy, DJ.,Sasli R., Agus S. 2009. Modal Sosial: Unsur-Unsur Pembentuk. http://p2dtk.bappenas.go.id.

Krisnamukti, B.P., Dhamayanti, K.G.H., Maharani, Y. dan Putri, S.A. 2020. Implementasi Nilai Pancasila Dalam Kehidupan Mahasiswa Fakultas Pertanian Universitas Brawijaya Di Malang. Jurnal Rontal Keilmuan PKn. Vol.9. No. 1: 66-72.

Lestari, P.F.K., W. Windia, dan Astiti, N.W.S. 2015. Penerapan Tri Hita Karana untuk Keberlanjutan Sistem Subak yang 
Menjadi Warisan Budaya Dunia: Kasus Subak Wangaya Betan, Kecamatan Penebel, Kabupaten Tabanan Jurnal Manajemen Agribisnis Vol. 3, No. 1: 22-33.

Mudarta, K.G. 2009. Jaringan Sosial (Networks) dalam Pengembangan Sistem dan Usaha Agribisnis: Perspektif Teori dan Dinamika Studi Kapital Sosial. Forum Penelitian Agro Ekonomi, Volume 27, No.1, Juli 2009.

Octavian, W.A.. 2018. Urgensi Memahami dan Mengimplementasikan NilaiNilai Pancasila Dalam Kehidupan Sehari-Hari Sebagai Sebuah Bangsa. Jurnal Bhinneka Tunggal Ika, Volume 5, Nomor 2: 123-128.

Raditya, I.N. 2020. Isi Butir-Butir Pengamalan Pancasila Lengkap Sila 1 Sampai 5. https://tirto.id/f5MwIsi Butir-Butir Pengamalan Pancasila Lengkap Sila 1 Sampai 5 Tirto.ID,

Ravesteijn. W. dkk. 2011. "River system in transition: pathway and stakeholder involvement", dalam C. A. Brebbia (ed) River Basin Management VI, WIT transactions on ecology and the environment, Volume 146: 327-338. United Kingdom: Witpress

Roth, D. and Sedana, G. 2015. Reframing Tri Hita Karana: From 'Balinese Culture' to Politics. The Asia Pacific Journal of Anthropology Vol.16, Issue 2: 157-175.

Saptana, Hendiarto, Sunarsih, dan Sumaryanto. 2001. Tinjauan Historis dan Perspektif Pengembangan Kelembagaan Irigasi Di Era Otonomi Daerah, FAE. Volume 19, No. 2: $50-65$

Sedana, G. I G.A.A.Ambarawati, and W. Windia. 2014. Strengthening Social Capital for Agricultural Development: Lessons from Guama, Bali, Indonesia. Asian Journal of Agriculture and Development. Vol.11 No.2:39-50 
Sedana, G. 2017. Menghentikan kepunahan subak di Bali: Pengembangan Agribisnis Berbasis Subak. Yogyakarta: Pustaka Larasan.

Sedana, G. and I N.D. Astawa. 2017. Revitalization of Farmers OrganizationFunctions Towards Agribusiness for Its Sustainability: Ideas for Traditional Irrigation Organizationin Bali Province, Indonesia. International Journal of Development Research Vol. 7, Issue 11: 1725817262

Sedana, G. 2020. Pengembangan Koperasi Subak: Kasus Subak Guama di Kabupaten Tabanan, Provinsi Bali. Jurnal Agribisnis dan Agrowisata (Journal of Agribusiness and Agritourism, Vol. 9, No. 3: 394-403.

Sedana, G. and A. Rahmat. 2020. Alternatives Policies to Strengthen the Traditional Irrigation System for Suportting the Food Security Program: Case of the Subaks' System in Bali, Indonesia. International Journal of Advanced Science and Technology 29 (7s), 973-984.

Subejo. 2004. Peranan Social Capital Dalam Pembangunan Ekonomi: Suatu Pengantar Studi Social Capital di Pedesaan Indonesia. Majalah Agro Ekonomi Vol. 11.No.1.

Suwarnata, A.A.E.2011.Keberlanjutan Sistem Subak di Perkotaan Kasus Subak Anggabaya di Kawasan Kelurahan Penatih, Kecamatan Denpasar Utara, Kota Denpasar. Tesis.Program Studi Agribisnis,Pasca Sarjana UNUD.Denpasar

Wibisono, S.C. 2013. Irigasi Tirtayasa : Teknik Pengelolaan Air Kesultanan Banten Pada Abad Ke-17 M. AMERTA, Jurnal Penelitian dan Pengembangan Arkeologi Vol. 31 No. 1: 180.

Windia, W.2006.Transformasi Sistem Irigasi Subak yang Berlandaskan Konsep Tri Hita Karana. Denpasar : Pustaka Bali Post. 
Windia,W. dan W.A.A.Wiguna, W.A.A. 2013. Subak Warisan Budaya Dunia. Denpasar: Udayana University Press.

Windia, W., Sumiyati, dan G. Sedana. 2015. Aspek Ritual pada Sistem Irigasi Subak sebagai Warisan Budaya Dunia. Jurnal Kajian Bali, Vol.5, No.1: 23-56. 


\section{IMPLEMENTASI NILAI-NILAI PANGASILA DALAM KONSEP TRI HITA KARANA}

Made Sila

Fakultas Keguruan dan Ilmu Pendidikan Universitas Dwijendra madesila@undwi.ac.id

\section{PENDAHULUAN}

Pancasila yang telah disepakati oleh rakyat Indonesia sebagai ideologi negara dalam mengatur kehidupan berbangsa dan bernegara sejatinya mengandung nilai yang bersifat lestari dan universal. Lestari artinya nilai-nilai yang terkandung dalam Pancasila selalu ada dalam setiap kehidupan manusia, sedangkan universal nilai nilai Pancasila ada dalam perilaku kehidupan bangsa bangsa di dunia. Cuma rumusan nilai-nilai tersebut oleh pendiri negara Indonesia menjadi lima sila yang kemudian diberinama Pancasila. Namun dalam perkembangan sejarah bangsa Indonesia seringkali menghadapi berbagai tantangan dan ujian pada situasi sosial-politik dan kondisi zaman yang terus berubah. Sebagai ideologi terbuka, Pancasila menyiratkan bahwa nilai-nilai dasar Pancasila diharapkan dapat berkembang dan membentuk dasar perumusan kebijakan pemerintah sesuai dengan dinamika kehidupan masyarakat dan bangsa untuk mencapai tujuan negara.

Dalam praktik penyelenggaraan negara dan pemerintahan sejak orde lama, orde baru dan era reformasi, nilai-nilai filosofis 
Pancasila yang ada dipandang belum cukup untuk memiliki indeks penilaian untuk diimplementasikan dalam operasionalisasi aturan dalam merumuskan kebijakan pemerintahan, di mana interpretasi nilai-nilai Pancasila selalu berbeda-beda dalam merumuskan kebijakan pemerintahan untuk setiap rezim pemerintah. Bahkan Pancasila selalu hanya digunakan sebagai "jargon" oleh setiap rezim yang berkuasa dalam mempertahankan kekuasaannya terhadap pihak-pihak yang kritis atau tidak sejalan dengan politik rezim yang berkuasa. Akibatnya, Pancasila selalu kehilangan esensinya, karena setiap rezim pemerintahan selalu membangun wacana sendiri tentang esensi makna Pancasila, yang disesuaikan dengan kepentingan politiknya. Pada hal dalam kehidupan masyarakat Indonesia hampir setiap daerah dan suku bangsa memiliki nilai-nilai luhur yang bisa dipakai untuk memimplementasikan nilai-nilai Pancasila tersebut. Nilai-nilai Pancasila yang telah tumbuh dan berkembang dalam masyarakat, tidak bisa dipungkiri bahwa nilai-nilai tersebut secara tidak langsung dapat dijumpai dalam berbagai budaya, prilaku, maupun dalam sebuah konsep ajaran yang telah ada di dalam masyarakat dan dilaksanakan secara turun-temurun oleh masyarakat baik itu sebelum Pancasila itu dirumuskan dan ditetapkan ataupun setelah Pancasila itu ditetapkan sebagai sebuah Ideologi Negara. Nilai, budaya, atau ajaran konsep yang telah ada dalam masyarakat tersebut sampai saat ini masih terlaksana dan tetap eksis dalam bingkai Pancasila. Hal ini menandakan bahwa budaya, ajaran atau konsep yang dilaksanakan oleh masyarakat tersebut dapat bersinergi dan sejalan dengan nilai-nilai Pancasila yang dirumuskan oleh pendiri Negara, atau dapat dikatakan bahwa budaya, ajaran atau konsep masyarakat tersebut merupakan sebuah implementasi atau cerminan dari nilai nilai Pancasila yang dilaksanakan secara baik oleh masyarakat dalam suatu bentuk budaya atau ajaran yang lestari. Implementasi atau cerminan dari nilai-nilai Pancasila dalam suatu budaya atau ajaran dalam 
masyarakat Indonesia salah satunya dapat dilihat dalam konsep ajaran Tri Hita Karana. Konsep Tri Hita Karana . Tri Hita Karana memiliki arti tiga penyebab kesejahteraan (Tri = tiga, Hita = sejahtera, Karana $=$ penyebab). Tri Hita Karana adalah suatu konsep ajaran agama Hindu di Bali yang dipercaya oleh masyarakat Bali dapat menyeimbangkan dan mennyelaraskan suatu demensi kehidupan dalam rangka mencapai sebuah kebahagian atau kesejahteran.

\section{PEMBAHASAN}

Nilai- nilai Pancasila adalah sebuah nilai adi luhung yang dirumuskan oleh para pendiri Negara Indonesia yang termuat secara terperinci dalam konstitusi Negara Indonesia. Pancasila sebagai Dasar Negara sebagai sebuah Stats fundamental norm yang tersurat dalam alenia keempat Pembukaan Undang-Undang Dasar Negara Republik Indonesia Tahun 1945. Dalam pidato Bung Karno pada sidang BPUPKI mengakatakan bahwa Pancasila bersumber dari kristalisasi nilai nilai yang telah tumbuh dan berkembang dalam masyarakat Indonesia, yang memiliki karakteristik majemuk atau heterogen. Nilai-nilai inilah yang kemudian diintisarikan oleh para pendiri Negara yang selanjutnya dirumuskan dalam lima nilai yang begitu mencerminkan kekhasan bangsa Indonesia yang dikenal dengan sebutan Pancasila (Hamid, 1991). Sebagai sebuah nilai yang bersumber dari nilai-nilai yang telah tumbuh dan berkembang dalam masyarakat, maka tidak bisa dipungkiri bahwa nilai-nilai Pancasila secara tidak langsung dapat dijumpai dalam berbagai budaya, prilaku, maupun sebuah konsep ajaran yang telah ada di dalam masyarakat dan dilaksanakan secara turun-temurun oleh masyarakat baik itu sebelum Pancasila itu dirumuskan dan ditetapkan ataupun setelah Pancasila itu ditetapkan sebagai sebuah Ideologi Negara. Nilai, budaya, atau ajaran konsep 
yang telah ada dalam masyarakat tersebut sampai saat ini masih terlaksana dan tetap eksis dalam bingkai Pancasila.

Hal ini menandakan bahwa budaya, ajaran atau konsep yang dilaksanakan oleh masyarakat tersebut dapat bersinergi dan sejalan dengan nilai-nilai Pancasila yang dirumuskan oleh pendiri Negara, atau dapat dikatakan bahwa budaya, ajaran atau konsep masyarakat tersebut merupakan sebuah implementasi atau cerminan dari nilainilai Pancasila yang dilaksanakan secara baik oleh masyarakat dalam suatu bentuk budaya atau ajaran yang lestari. Implementasi atau cerminan dari nilai-nilai Pancasila dalam suatu budaya atau ajaran dalam masyarakat Indonesia salah satunya dapat dilihat dalam konsep ajaran Tri Hita Karana. Konsep Tri Hita). Tri Hita Karana adalah suatu konsep ajaran agama Hindu di Bali yang dipercaya oleh masyarakat Bali bahwa kebahagiaan hidup dapat tercapai bila ada keseimbangan hubungan antara manusia, dengan sang Penciptan ( perhyangan ), antara ,manusia dan manusia pawongan) dan antara manusia dengan lingkungan (palemahan). Implementasi Nilai-Nilai Pancasila dalam Konsep Tri Hita Karana mermungkinkan masyarakat Bali dapat dan mennyelaraskan suatu demensi kehidupan dalam rangka mencapai sebuah kebahagian atau kesejahteran. Konsep Tri Hita Karana ini memang baru dipopulerkan pada tahun 1966 dalam Konferensi Daerah I Badan Perjuangan Umat Hindu Bali bertempat di Perguruan Dwijendra Denpasar. Namun spirit dari konsep ajaran ini terlahir dari inti sari ajaran agama hindu, dalam kitab suci Begawad Gita III sloka 10, yang meliputi unsur-unsur Sangyang Jagat Karana, Buana, dan Prajapati yang di dalam Konsep Tri Hita Karana diistilahkan Parhyangan, Palemahan dan Pawongan.

Melalui penulisan ini bisa dilihat bahwa konsep Tri Hita Karana merupakan sebuah konsep ajaran Hindu yang memuat hubungan yang baik antara manusia dengan Tuhannya, manusia dengan lingkungannya dan manusia dengan sesamanya, yang jika ditelaah secara lebih mendalam, sangat sejalan atau sinergis dengan 
nilai-nilai Pancasila yang dimiliki oleh bangsa Indonesia yang mengandung lima nilai yakni; Nilai Ketuhanan (religius), Nilai Kemanusiaan (solidaritas), Nilai Kesatuan (cinta tanah air), Nilai demokrasi/kerakyatan (mufakat), Nilai berkeadilan dan kesejahteraan. Sehingga nilai-nilai dalam konsep ajaran agama Tri Hita Karana, ketika diperkenalkan kepada masyarakat Bali sangat mudah dipahami dan diterima oleh masyarakat Hindu di Bali, oleh karena itu dapat dikatakan konsep Tri Hita Karana ini dapat dikatakan sebagai sebuah implementasi dari nilai-nilai Pancasila yang ditetapkan sebagai suatu ideologi Negara melalui berbagai impelementasi pelaksanaannya dalam kehidupan sehari-hari.

Unsur- unsur Tri Hita Karana ini jika kita dalami dalam kitab suci Bagawad Gita (III.10), yang berbunyi sebagai berikut: "Sahayajnah prajah sristwa pura waca prajapatih anena prasawisya dhiwan esa wo'stiwistah kamadhuk" yang artinya: Pada jaman dahulu Prajapati menciptakan manusia dengan yadnya dan bersabda: dengan ini engkau akan berkembang dan akan menjadi kamadhuk dari keinginanmu. Dalam sloka Bhagavad-Gita tersebut ada nampak unsur yang saling berhubungan untuk mendapatkan kebahagian yaitu terdiri tiga unsur yaitu, Sanghyang Jagatkarana, (Tuhan) Bhuana (alam Semesta) dan Manusa itu sendiri. Penjabaran Tri Hita Karana dalam kehidupan umat Hindu diistilahkan dalam bentuk tiga hubungan yang harmonis yaitu,

Hubungan manusia dengan Tuhannya yang diwujudkan dengan Dewa yadnya (Perhyangan). Parahyangan adalah hubungan harmonis antara manusia dengan Ida Sang Hyang Widi Wasa/ Brahman sang pencipta / Tuhan Yang Maha Esa. Sebagai Umat beragama atas dasar konsep theology yang diyakininya khususnya Umat Hindu yang pertama harus dilakukan adalah bagaimana berusaha untuk berhubungan dengan Sang Pencipta melalui kerja keras sesuai dengan kemampuan yang dimilikinya.

Hubungan manusia dengan alam lingkungannya yang diwujudkan dengan Bhuta yadnya (Palemahan), Dalam Kitab 
Atkarvaveda XIX.9.1, menyebutkan "Santa dyuh santa prthivi, Santam idam urvantariksam, Santa udan vatir apah, Santa nah sautu osadih", artinya: Semoga langit penuh damai, semoga bumi bebas dari gangguan- gangguan, semoga suasana lapisan udara yang meliputi bumi yang luas menjadi tenang, semoga perairan yang mengalir menyejukkan dan semoga suasana tanaman dan tumbuhan menjadi bermanfaat untuk kami.

Hubungan antara manusia dengan sesamanya diwujudkan dengan Pitra, Resi, Manusia Yadnya (Pawongan). Penerapan Tri Hita Karana ternyata mampu mencerminkan penerapan nilai-nilai Pancasila dalam kehidupan bermasyarakat atau dapat dikatakan konsep Tri Hita Karana bersinergi dengan nilai-nilai Pancasila yang mengandung lima nilai yakni, nilai Ketuhanan Yang Maha Esa, Nilai Kemanusiaan yang adil dan beradab, Nilai Persatuan Indonesia, Nilai Kerakyatan yang dipimpin oleh hikmat kebijaksanaan dalam permusyawaratan perwakilan, dan Nilai Keadilan sosial bagi seluruh rakyat Indonesia.

Penerapan konsep Tri Hita Karana sebagai bentuk implementasi nilai-nilai Pancasila dalam kehidupan masyarakat terjabar dalam tiga dimensi hubungan tersebut, yang dapat diperinci sebagai berikut;

1. Implementasi konsep Parhyangan

Konsep Perhyangan dalam Tri Hita Karana adalah Hubungan yang harmonis antara Manusia dengan Tuhan (Ida Sang Hyang Widi Wasa), yang menegaskan bahwa kita harus selalu sujud bakti kepada Tuhan, Sang Pencipta Alam Semesta beserta isinya. Ini merupakan bentuk hubungan vertikal antara manusia dengan Tuhan. Bentuk pelaksanaan konsep parahyangan ini adalah melaksanakan ajaran-ajaran agama, melaksanakan kegiatan upacara keagamaan, dan membangun tempat sembahyang. Menjaga hubungan harmonis dengan Tuhan tentu kita pun harus selalu berada didalam jalan-Nya,menjauhi 
larangan-Nya dan selalu rajin sembahyang dengan tujuan mengucap syukur atas segala berkah maupun kesulitan yang sedang kita hadapi agar diberikan petunjuk dan Tuhan menjadikan kita pribadi yang semakin baik kedepannya. Dalam Pancasila Hubungan ini menunjukkan ketaqwaan manusia kepada Sang Pencipta sesuai dengan ajaran Agama atau keyakinan masing-masing. Hubungan ini bersifat pribadi (personal), sehingga oleh masyarakat di Bali pelaksanaan konsep parhyangan ini dilaksanakan sesuai dengan keadaan, ruang dan waktu, dimana mereka tinggal atau dikenal dengan istilah desa, kala, patra. Dalam konsep ini setiap orang diharapkan melaksanakan ajaran agama sesuai dengan perintah dan larangannya serta menghormati setiap orang dalam melaksanakan ajaran agama. Penerapan parhyangan sesuai desa, kala, patra mengandung arti yang sangat luas dan fleksibel. Dalam Pancasila berketuhanan yang maha esa sesuai dengan kemanusiaan yang adil dan beradab, artinya kita menyembah Tuhan berdasarkan keyakinan/agama dan selalu disesuaikan dengan daerah dan budaya masing-masing. Dengan demikian akan timbul rasa saling menghormati antar pemeluk agama. Dari konsep keyakinan ini akan dapat meningkatkan kualitas keimanan seseorang, sehingga akan melahirkan insan berakhlak serta memiliki iman yang baik. Cerminan dari prilaku yang beriman dan berakhlak ini dapat dijumpai dari aktivitas religius masyarakat Hindu di Bali dalam melakukan persembahyangan ataupun puja mantram untuk dapat lebih mendekatkan diri kepada Sang Hyang Widi Wasa (Tuhan Yang Maha Esa) dengan tingkatan pelaksanaan peribadatan di lingkungan antar daerah yang dikenal dengan sebutan Khayangan Jagat, di lingkungan tempat suci di desa yang disebut Khayangan Tiga, serta peribadatan di lingkungan keluarga yang disebut sanggah, merajan, paibon ataupun kawitan. Penerapan hubungan parhyangan dalam konsep Tri 
Hita Karana sangat meimplementasikan pengamalan nilai Ketuhanan Yang Maha Esa (Sila Pertama) dalam Pancasila, yang dalam konstitusi dasar negara Indonesia diatur dalam pasal 29 UUD 1945 yang menjamin tiap-tiap penduduk untuk memeluk agama dan beribadah menurut agama dan kepercayaannya itu." Oleh karena itu konsep Parhyangan dalam Tri Hita Karana merupakan sebuah cerminan penerapan nilai Ketuhanan di Bali yang mampu terlaksana dengan baik dan ajeg (lestari) dengan kebebasan dan kenyamanan penerapannya karena telah dipayungi dengan aturan, hukum adat, Implementasi Nilai-Nilai Pancasila dalam Konsep Ajaran Agama serta kebiasaan masyarakat hindu di Bali (dresta).

2. Implementasi konsep Palemahan

Dalam konsep palemahan menunjukkan bagaimana manusia memiliki suatu kepekaan dan kepedulian terhadap lingkungan sekitar mereka, dalam konsep palemahan hubungan ini terjalin karena diyakini suatu kehidupan manusia tidak bisa terlepas dari alam atau lingkungan, setiap kebutuhan manusia Bali dari masa dahulu sampai saat ini sangat bergantung dari alam, sehingga sebagai timbal balik dari ketergantungan tersebut adalah perlunya suatu kepedulian terhadap kelestarian alam tersebut sehingga apa yang diambil dari alam sebagai bagian dari pemanfaatan kebutuhan manusia mampu dikembalikan lagi ke alam dalam wujud pelestarian. Konsep palemahan dalam Tri Hita Karana sangat erat kaitannya dengan berbagai upacara yang dilaksanakan oleh umat hindu di Bali sebagai bagian dari kepekaan dan kepedulian terhadap alam dan lingkungan, seperti misalnya upacara tumpek bubuh (wariga) bentuk apresiasi umat hindu akan hasil yang mereka dapatkan dari tumbuhtumbuhan atau pepohonan yang ada di sekeliling mereka, kemudian ada upacara tumpek kandang ( tumpek Uye ) sebagai bagian dari bentuk ucapan terima kasih dan kepedulian terhadap binatang atau hewan-hewan ternak yang telah 
mendatangkan kesejahteraan bagi kehidupan mereka, berbagai macam upacara pecaruan, baik pecaruan alit, madya, ataupun utama bergantung tingkatan pelaksanaannya, yang ditujukan untuk menetralisir kehidupan alam mikroskosmis (bhuana alit) dan makrokosmis (bhuana agung) agar senantiasa seimbang sehingga tidak menyebabkan adanya bencana seperti: gempa, longsor, banjir, wabah penyakit, hama, dan lain sebagainya. Diharapkan dari keyakinan ini akan dapat meningkatkan kepekaan dan kepedulian sehingga akan melahirkan insan yang respek dan care terhadap lingkungan sekitar. Penerapan hubungan palemahan dalam konsep Tri Hita Karana sangat meimplementasikan berbagai pengamalan nilai dalam Pancasila, karena dalam konsep palemahan Tri Hita Karana ini mengandung dan mengajarkan nilai nilai cinta tanah air yang merupakan cerminan nilai sila ketiga dalam Pancasila, mengajarkan nilai keseimbangan antara hak dan kewajiban (apa yang ditanam itu yang dipetik) yang merupakan cerminan sila kelima, serta nilai tenggang rasa, peduli yang merupakan cerminan yang sangat kental dari sila kedua dalam Pancasila.

3. Implementasi konsep Pawongan

Pawongan merupakan hubungan manusia dengan sesamanya, manusia diharuskan membentuk hubungan yang selaras dengan manusia lainnya. Hubungan yang selaras tersebut dapat diwujudkan dalam hubungan dalam keluarga, hubungan dalam persahabatan, dan hubungan dalam pekerjaan. Dalam kitab suci Atharvaveda XII.1.45. ditegaskan: Janam bibhratî bahudhâ vivâcasam nana dharmanam prthiviyathaukasam, sahasram dhara dravinasya me duham dhruveva dhenur anapasphuranti.

Terjemahannya.

"bekerjalah keras untuk kejayaan ibu pertiwi,tumpah darah dan bangsamu yang menggunakan berbagai bahasa. Berikanlah penghargaan yang pantas kepada mereka yang 
menganut agama yang berbeda hargailah mereka seluruhnya seperti halnya keluarga yang tinggal dalam satu rumah. Curahkanlah kasih sayangmu, bagaikan induk sapi yg selalu memberikan susu kepada manusia.

Bunda pertiwi akan memberikan kekayaan dan kesejahteraan kepada kamu, umat manusia sebagai anak-anaknya"

Pawongan mempunyai makna kita harus bisa menjaga keharmonisan hubungan dengan keluarga, teman dan masyarakat. Dalam menjaga keharmonisan tentunya jauhkanlah sikap saling membeda-bedakan berdasarkan derajat, agama ataupun suku. Dalam kehidupan bermasyarakat, semua orang yang ada di Indonesia memiliki harkat dan derajat yang sama, persamaan dalam mendapatkan peklerjaan serta bidang hukum dan pemerintahan. Sehingga sebagai warga negara memiliki kedudukan yang sama di depan hukum, hukum tidak ada hal yang membedakan antara warga yang satu dengan yang lain. Sebagai warga negara Indonesia yang berpegang pada Pancasila, tidak boleh berbuat semena-mena kepada orang lain. Harus saling memanusiakan manusia, jangan berbuat semaunya sendiri dalam menjalani kehidupan sehari-hari. Bersikap adil menjadi salah satu fondasi dalam mengamalkan Pancasila sila kedua. Di mana dalam setiap menyelesaikan masalah harus dilihat duduk permasalahannya. Bukan menitik beratkan pada latar belakang individunya seperti suku, ras, budaya, dan lainnya. Setiap orang memiliki hak untuk berpendapat. Untuk menjaga keamanan dan kenyamanan dalam bermasyarakat, sebaiknya saling menghargai pendapat orang lain. Kita tidak boleh memaksakan apa yang kita inginkan kepada orang lain. Karena jika hal itu dilakukan orang lain kepada kita, kita juga tidak akan terima. Tidak membeda-bedakan manusia berdasarkan suku, agama, warna kulit, tingkat ekonomi, dan pendidikannya. Saling mencintai antar sesama warga Indonesia, agar tercipta kerukunan dalam hidup bermasyarakat dan 
bernegara. Sebagai individu yang berpegang teguh pada Pancasila, harus rela melonong siapa pun, kapanpun, dan di mana pun bagi orang lain yang membutuhkan Sebagai sesama mahluk ciptaan Tuhan, manusia diajarkan untuk tidak membeda-bedakan ciptaannya dan dapat belajar menghargai arti perbedaan. dengan Pancasila Hubungan ini menunjukkan bagaimana rasa persaudaraan, kepedulian manusia terhadap sesamanya, baik antara umat sedarma, antara umat beda keyakinan, maupun umat beda asal daerah. Oleh masyarakat Hindu di Bali pelaksanaan konsep pawongan ini dapat dilaksanakan dengan membina hubungan yang harmonis antara masyarakat hindu lainnya baik umat hindu seluruh Bali, umat hindu di desa yang dikenal dengan sebutan krama desa, atapun dengan sesama anggota keluarga atau yang sering diistilahkan dengan hubungan pesawitran kulewarga. Terlaksananya ajaran pawongan dalam konsep Tri Hita Karana di Bali diperkuat dengan adanya organisasi-organisasi sosial (sekaa) yang semakin mempererat ikatan pasuka-dukan (hubungan senasib sepenanggungan) yang terjalin antara masyarakat di Bali, karena keberadaan organisasi sosial ini hampir ada dalam setiap dimensi kelompok umur maupun profesi masyarakat hindu di Bali, seperti misalnya Bebanjaran (untuk anggota keluarga yang telah menikah atau berkeluarga), sekaa teruna (untuk anak anak muda), sekaa manyi (kumpulan masyarakat yang memiliki pekerjaan memanen sawah), sekaa subak (organisasi pengairan di Bali), dan sebagainya. Konsep pawongan dalam Tri Hita Karana tidak dapat dipisahkan dari kodrat manusia selaku makhluk sosial yang tidak dapat hidup sendiri, pastinya dalam melaksanakan kehidupan ataupun pemenuhan kebutuhan sehari-hari memerlukan bantuan sesama lainnya. Hubungan dalam konsep pawongan ini di Bali, tidak saja dikhususkan kepada umat se-agama semata, namun juga hubungan sosial yang baik dengan umat agama lain yang dalam tatanan struktur 
masyarakat adat di Bali sering disebut dengan membina hubungan dengan wong sunantara atau krama tamiu (masyarakat di luar Bali). Hubungan sosial ini dapat dilihat dengan adanya budaya mejenukan (mendatangi warga yang berbahagia ataupun terkena musibah), ngejotin (memberikan sesuatu seiklasnya, umumnya berupa bahan pangan) yang dapat dilakukan dengan sesame manusia lainnya tanpa batas agama ataupun daerah. Penerapan hubungan pawongan dalam konsep Tri Hita Karana juga sangat merefleksikan berbagai pengamalan nilai dalam Pancasila, karena dalam konsep pawongan ini selain mengajarkan nilai-nilai cinta kasih dan kemanusiaan yang tinggi sebagai cerminan sila kedua dalam Pancasila, juga menunjukkan adanya nilai-nilai demokrasi sebagai cerminan sila keempat dalam Pancasila, yang terbentuk dari hubungan-hubungan sosial yang oleh masyarakat di Bali diwujudkan dalam berbagai bentuk Sekaa (organisasi sosial). Melalui keberadaan Sekaa atau perkumpulan ini maka tentu banyak kebijakan atau keputusan yang diambil demi tujuan yang ingin dicapai bersama oleh organisasi yang dilakukan melalui berbagai pertemuan atau sering dikenal dengan istilah sangkep atau paruman. Dalam sangkep ataupun paruman inilah benar-benar nilai demokrasi tersebut terlihat melalui proses permufakatan yang dipimpin oleh seorang pemimpin rapat atau klian sekaa, sehingga begitu kental refleksi sila keempatnya serta nilai sila persatuan (ketiga) yang juga tumbuh mengiringi hubungan sosial ini.

Semua organisasi sosial yang terbentuk dalam desa pakraman di Bali selalu mencerminkan nilai religius, kemanusiaan, persatuan , musyawarah dan mewujudkan kesejahteraan hidup. Karena mulai dari terbentuknya sudah mencari hari baik (duasa), memiliki tugas dan kewajiban pada perhyangan dan melaksanakan upakara tertentu sebagai wujud bhakti pada Ida Sang Hyang Widi Wasa (Tuhan Yang Maha Esa). Dalam 
setiap kegiatan selalu mengutamakan dan menjunjung tinggi harkat dan martabat manusia, untuk mewujudkan persatuan dan kesatuan. Konsepsi mengenai hidup harmonis, di samping penting dan selalu ditekankan dalam ajaran-ajaran agama Hindu, juga dipelihara melalui ritus-ritus keagamaan. Ditemukan banyak terminologi agama yang bermakna bahwa "kita adalah sebuah keluarga dan "kita bersaudara" melalui terminologi Wasudewa Kutumbakam yang bersumber dari teks Maha Upanisad. Persaudaraan antar sesama harus dilandasi prinsip bahwa "setiap orang hendaknya menjaga dan menjadikan semua orang berbahagia". Oleh karena itu, setiap orang harus menjaga dan memperlakukan orang lain seperti halnya menjaga dan memperlakukan dirinya sendiri. Konsepsi ini dikenal dengan istilah tat twam asi. Hal ini dilandasi pemikiran bahwa "manusia secara esensial sama, walaupun secara fenomena tidak sama". Tujuan hidup manusia Hindu adalah Mokshartam Jagadita, yaitu kebahagiaan lahir dan batin, serta dapat bersatu kembali dengan Tuhan setelah meninggal ( moksa).

\section{PENUTUP}

Dari Pambahasan tersebut ada beberapa hal yang penting dapat disimpulkan

1. Bahwa konsep Tri Hita karana yang menjadi landasan bagi masyarakat Hindu di Bali adalah konsep untuk mewujudkan tujuan hidup yaitu kebahagiaan lahir dan batin ( Mokshartam Jagadita) dengan membina kehidupan yang harmonis antara manusia dengan Tuhan Yang Maha Esa, sesama manusia dan lingkungan.

2. Pelaksanaan konsep Tri Hita Karana merupakan penjabaran yang kongkrit dari nilai-nilai yang terkandung dalam Ideologi Pancasila. Sehingga masyarakat lebih mudah 
memahami dari esensi nilai-nilai yang terkandung dalam Ideologi Pancasila yang masih bersifat abstrak.

3. Dalam kehidupan berbangsa dan bernegara masyarakat Hindu Bali sebagai bagian dari masyarakat Indonesia, sudah mengamalkan nilai-nilai ideologi Pancasila dalam kehidupan sehari-harinya tanpa mengalami konflik. Mengapa masyarakat Hindu Bali dapat melaksanakan kedua ideologi ini tanpa mengalami pertentangan atau konflik, karena kedua ideologi ini sama-sama sebagai ideologi terbuka dan ternyata memiliki landasan ontologis yang relevan.

\section{DAFTAR PUSTAKA}

Kajeng, I Nyoman dkk., 1991. Saramuscaya Alih Bahasa. Jakarta: Yayasan Dharma Sarasi Mantra

Mahendra, Putu Ronny Angga., Made Kartika, 2019. Tri Hiota Karana Sebagai Landasan Memperkuat Kepemimpinan Pancasila, Seminar Nasional INOBALI 2019

I Gede dan Cok Rai Sudharta, 1997/1978. Menawa Dharmasastra. Alih Bahasa, Departemen Agama RI

Pandit, S, 1991. Bhagawad Ghita, Terjemahan dan Keterangan. Jakarta: Yayasan

Wiana, I Ketut. 2004. Menuju Bali Jagadhita: Tri Hita Karana SeharaiHari dalam Bali: Menuju Jagadhita. Aneka Perspektif. 


\title{
AKTUALISASI NILAI PANCASILA DALAM PERSPEKTIF TRI HITA KARANA PADA MASA PANDEMI GOVID-19
}

\author{
I Wayan Eka Santika
}

Fakultas Keguruan dan Ilmu Pendidikan Universitas Dwijendra

Ekasantika56@gmail.com

\section{PENDAHULUAN}

Sebagai suatu negara yang besar sudah barang tentu harus memiliki dasar negara yang menjadi dasar funadamental berdirinya sebuah negara. Sehingga arah dan tujuan penyelengaraan negara dapat diwujudkan sebagai suatu cita-cita kesepakatan kolektif bagi seluruh anggota masyarakat dalam bentuk tujuan nasional. Tujuan nasional ini didasari oleh idiologi yang dianut oleh negara atau bangsa tersebut sehingga tujuan nasionalnya tidak terlepas dari corak atau idiologi bangsa itu sendiri. Karena pada hakikatnya idiologi adalah sumber nilai dan prinsip dalam penyelenggaraan kehidupan berbangsa dan bernegara.

Bangsa Indonesia sebagai bangsa yang sudah merdeka ketika tahun 1945 ketika itu sudah disadari betul oleh fuonding fathers kita bahwa kita adalah bangsa yang besar dengan berbagai macam kemajemukan, keaekaragaman, dan keistimewaan dari negara atau bangsa-bangsa lain di dunia. Oleh karena keanekaragaman tersebut diperlukan suatu dasar yang mampu 
menjebatani atau sebagai frame dalam kehidupan berbangsa dan bernegara dalam mewujudkan cita-cita dan tujuan bersama. Pada akhirnya disepakati bahwa Istilah "Pancasila" yang dicetuskan oleh Ir Soekarno pada tanggal 1 Juni 1945 disepakati sebagai identitas dan dasar kehidupan kenegaraan yang mampu menyatukan keanekaragaman bangsa Indonesia.

Jika kita lihat dari konteks sejarah, perumusan sila-sila Pancasila melewati proses yang sangat panjang. Dimulai dari jaman kerajaan yang sudah diaktualisasikan sampai dengan perjuangan bangsa melawan penjajah dan hingga saat ini. Pancasila yang terdiri dari lima nilai-nilai dasar kehidupan berbangsa dan bernegara adalah cerminan kehidupan masyarakat bangsa Indonesia sendiri. Sehingga kebenaran dan keampuhan tidak bisa dipungkiri lagi, karena bersumber dari bangsa Indonesia. Oleh karena itu dikatakan bahwa bangsa Indonesia adalah Causa Materialis dari pancasila. Karena Pancasila berasal dari adat kebiasaan, kebudayaan dan agama yang ada di Indonesia (Notonagoro, 1975). Pancasila digali dari nilai yang terdapat dalam masyarakat. Nilai tersebut tersebar pada seluruh masyarakat, dan digunakan untuk mengatur kehidupan masyarakat.

Namun demikian bagi masyarakat di daerah-daerah pastilah memiliki nilai-nilai atau idioliogi tersendiri yang tidak lepas dari adat dan kebiasaan maupun agama yang dianut oleh masarakatnya. Contohnya di Bali yang memegang teguh idiologi dan filosofi Trihita karana yang bersumber dari ajaran agama hindu dan diyakini sebagai sumber kebahagian dan keharmonisan hidup. Melalui konsep Parahyangan, Pawongan dan Palemahan yang jika dilaksakanan dengan baik akan memberikan keselarasan dan keseimbangan kehidupan untuk menunjang terjadinya keharmonisan kehidupan. Dengan ideologi TRI HITA KARANA, masyarakat menganggap bahwa ideologi ini adalah bersumber dari ajaran agama Hindu yang bersifat religius/spiritual (Suasthi dan Suija, 2018). 
Menarik kita mellhat bagaimana eksistensi dan kesaktian Pancasila dewasa ini ketika suasana Covid 19 melanda dunia. Tidak terkecuali bangsa Indonesia yang seakan mempengarusi seluruh aspek kehidupan didunia. Pancasila kesaktiannya seolah diuji dalam membimbing bangsa indonesia agar tetap kuat dan tegar dalam menghadapai segala tantangan dan hambatn kehidupan bernegara. Terlebih jika kita lihat atau telisik dari sudut pandang Konsep Tri Hita Karana yang merupakan dasar filsafat orang Bali dalam mewujudkan keharmonisan hidup khususnya dalam nmenghadapai tantangan Covid-19 saat ini. Karena pada dasarnya masyarakat Bali yang dominan menganut agama hindu dengan idiologi Trihita karana yang sudah diyakini dan dilaksnakan berjalan beriringan dengan keyakinan akan idiologi Pancasilanya sebagai konsekuensi kehudupan berbangsa dan bernegara. Sebagai bagian dari masyarakat Indonesia, masyarakat Hindu di Bali juga mengakui menganut dan melaksanakan ideologi Pancasila sebagai ideologi nasional dalam kehidupan berbangsa dan bernegara (Sukadi, 2007).

\section{PEMBAHASAN}

\subsection{Idiologi Tri Hita Karana dalam Masyarakat Pancasila}

Ideologi Tri Hita karana secara historis merupakan warisan ajaran Maha Mpu Kuturan yang secara tradisi dipahami sebagai peletak dasar desa pakraman (desa adat di Bali) dalam tatanan kehidupan masyarakat Bali sejak abad ke 11 (SARAD dalam Sukadi, 2020). Kemudian dari konsep desa pakraman inilah, yang kemudian dikaitkan pula dengan konsep pura kahyangan tiga atau pura kahyangan desa, melahirkan konsep TRI HITA KARANA sebagai tatanan harmoni hidup manusia dengan alam lingkungan, sesama manusia, dan hubungannya dengan Tuhan Yang Maha Esa (Sukadi, 2020). Dengan menjalankan ketiga konsep ini diyakini 
keseimbangan,keselarasan dan keharmonisan kehidupan manusia di diunia ini dapat terwujud.

Sebagai suatu ajaran yang diyakini dan dilaksanakan sampai saat ini khususnya bagi masyarakat bali, oleh karena itu bagi siapapun yang ada di Bali khususnya wajib melaksanakan dan menjunjung teguh TRI HITA KARANA ini. Karena pada dasarnya TRI HITA KARANA tidaklah hanya merupakan filosofi agama Hindu, tapi merupakan suatu konsep yang mengandung nilai-nilai universal (Suteja dalam Sukadi, 2020 dan Dalem, 2007). Dikatakan universal karena pada hakikatnya jika semua manusia melaksanakan TRI HITA KARANA maka keharmonisan hidup dapat terwujud. Dalam konsep TRI HITA KARANA ini memandang bahwa hubungan manusia dengan alam lingkunganya adalah suatu hukum sebab akibat yang sifatnya universal. Artinya bahwa manusia hidup memerlukan alam lingkungan, begitu sebaliknya lingkungan membutuhkan manusia sehingga terwujud kelestarian dan keseimbangannya.

Konsep TRI HITA KARANA berasal dari kata tri yang berarti tiga; hita yang berarti sejahtera, bahagia, rahayu; dan karana yang berarti sumber penyebab. Jadi TRI HITA KARANA berarti tiga sumber penyebab adanya kesejahteraan, kebahagiaan, dan kerahayuan dalam hidup dan kehidupan semua makhluk ciptaan Tuhan (Sudarma, 1971; Kaler, 1983). Ketiga penyebab kebahagiaan hidup ini akan terwujud apabila tercipata hubungan yang harmonis antara manusia dengan penciptanya (Tuhan Yang Maha Esa), manusia dengan sesamanya, dan manusia dengan alam lingkungan tempat kehidupannya. Ketiga konsep yang dimaksud sebagai inti dari ajaran TRI HITA KARANA meliputi Parahyangan, pawongan dan palemahan. Parahyangan artinya Hubungan antara manusia dengan Tuhannya yang diwujudkan dengan Dewa yadnya (upacara kepada para Dewa), Pawongan artinya menjalin hubungan baik dengan sesama manusia diwujudkan dengan Upacara Pitra, Resi, Manusia Yadnya (Upacara 
kepada leluhur dan seama manusia). dan palemahan artinya menjalin hububungan baik dan keseimbangan dengan alam lingkungannya yang diwujudkan dengan Upacara Bhuta yadnya (Upacara yang ditunjukan kepada alam bawah atau mahluk bawah). Dalam konsep yang dibahas ini tidak hanya diti njau dari segi upacara sebagai simbol implementasi Tri hita karana, tetapi juga aktualisasi dengan prilaku manusia bali itu sendiri.

Menurut Geriya dalam Suja (2010) pemikiran filsafat dari keduluan hingga kekinian bergerak dalam empat fase, yaitu berpusat pada alam (kosmosentris), berpusat pada Tuhan (teosentris), berpusat pada manusia (antroposentris), dan berpusat pada bahasa yang di gunakan (logosentris). Selanjutnya di tegaskan bahwa keempat fase itu diramu menjadi filsafat hidup Tri Hita Karana, sebagai suatu konsep yang harmoni. Dimana bagiannya adalah keseimbangan manusia dengan alam (palemahan), keseimbangan manusia dengan manusia (pawongan), dan keseimbangan dengan tuhannya (parahyangan).

Sebagai masayarakat Bali yang memegang teguh dengan adat dan budayanya serta didasari dengan ajaran agama hindu seperti penejelasan sebelumnya idiologi TRI HITA KARANA sangat dipegang teguh, hal ini dapat dibuktikan dengan berbagai bentuk upacara-upacara keagamaan denganberbabai wujud persembahan yang ada sebagai bentuk ceremonial rasa syukur kepada Tuhan, nilai-nilai kmasayarakatan yang dikembangkan lagi dengan konsep Menyame braya, Saling asah, Asih, dan Asuh. Kemudian perwujudan menghargai lingkungan dengan diadakannya berbagai upacara terhadap tanaman dan tanaman yang di balut dengan kain sebai rasa memanusiakan lingkungan.

Masyarakat Bali yang taat dan patuh juga dengan idiologi Pancasila dalam kehidupan kesehariannya yang mengakui kehidupannya dalam bingkai NKRI, disadari atau tidak berjalan beriringan bahkan saling mendukung dan menguatkan antara idiologi Trihita karana dengan Idiologi Pancasila. Karena pada 
dasarnya idiologi Pancasila merupakan manusia Indonesia seutuhnya atau digali dari nilai-nilai kebudayaan bangsa. Hal ini dapat dibuktikan dengan kedua idiologi tersbut menjelaskan mengenai hubungan manusia dengan Tuhannya, sebagai wujud Sila 1, dan konsep kemanusiaan dari sila II sampai dengan sila ke V. Hanya saja pada ajaran Trihita karana yang mengajarkan tentang menjalin hubungan baik dengan lingkungan sebenarnya pegejawantahan tugas manusia yang sadar sebagai mahluk ciptaan Tuhan untuk menjaga alam lingkunyannya wujud syukur terhadap Segala KaruniaNya yang tersirat dalam Sila pancasila ke 1.

Kesadaran manusia Bali Khususnya akan pentingnnya kedua Idiologi ini kembali diuji dan dibuktikan Terlebih ketika saat ini seluruh dunia yang dilanda suasana Pandemi Covid-19. Tidak terkecuali indonesia Khususnya Bali yang tekerna dampak paling parah dalam bidang ekonomi. Karena Bali tentunya sangat mengandalkan Pariwisatanya sebagai sumber pendapatan sebagain besar masyarakat Bali. Manusia Bali bahu-membahu supaya dapat saling menguatkan satu sama lain, dan berupaya bangkit dari situasi pandemi demi Kelangsungan kehidupan.

\section{Parahyangan}

Konsep parahyangan, yang artinya menjaga keharmonisan dengan Tuhan atau mengamalkan ajaranajaran Ketuhanan. Manusia dan masyarakat Bali meyakini bahwa segala yang ada di dunia ini termasuk manusia adalah bersumber dari dan, karena itu, pasti akan kembali menghadap kepada Tuhan Yang Maha Esa. Kesadaran ini mendorong manusia dan masyarakat Bali untuk meningkatkan crada dan bhakti (iman dan taqwa) kehadapan Ida Sang Hyang Widhi Waca sesuai dengan ajaran-ajaran agama, keyakinan, serta tradisi yang dianutnya (Sukadi, 2020). Lebih lanjut dijelaskan bahwa 
setiap lingkungan pranata sosial di Bali selalu ada di bangun tempat suci untuk memuliakan Tuhan sebagai wahana bagi manusia berhubungan dengan Tuhan. Begitu pula diyakini bahwa segala produk budaya dan peradaban manusia dan masyarakat Bali diciptakan adalah sebagai persembahan kepada Tuhan atau kepada para Dewa yang sering disebut dengan yadnya.

Hubungan ini menunjukkan bagaimana keyakinan manusia kepada Sang Pencipta sesuai dengan ajaran Agama atau keyakinan masing-masing, hubungan ini bersifat pribadi (personal), sehingga oleh masyarakat di Bali pelaksanaan konsep parhyangan ini dilaksanakan secara mayoritas sesuai ajaran agama Hindu serta sesuai dengan keadaan ruang dan waktu dimana mereka tinggal atau dikenal dengan istilah desa, kala, patra. Diharapkan dari konsep keyakinan ini akan dapat meningkatkan kualitas keimanan seseorang, sehingga akan melahirkan insan berakhlak serta memiliki iman yang baik (Adi Adnyana, 2020). Keimanan ini lebih diwujudakan dan diaktualisasikan dalam wujud prilaku sehari-hari dalam rasa saling menyayangi, mengasihi sesama mahluk ciptaan tuhan

Dengan konsep parahyangan ini menandakan bahwa manusia Bali harus menjalankan ajaran-ajaran Agama yang sesuai dengan Nilai sila I yaitu Ketuhanan Yang Maha Esa. Sebagai wujud rasa mempercayai tentang kekuatan sang pencipta dan memberikan ujian dan Cobaan kehidupan, oleh karena itu ketika Covid-19 sudah masuk ke Indonesia pada pertengahan maret 2020 telah banyak upacara-upacara keagamaan khususnya agama hindu gelar dalam bentuk yadnya kepada Tuhan untuk memohon keselamatan dan Wabah Virus ini segera berakhir. Di samping itu dalam ajaran Hindu diajarkan harus taat dan patuh kepada Catur Guru, yaitu empat guru yang harus 
dipatuhi dihormati dan di taati dalam kehidupan karena memberikan kesejahteraan dan ketentraman kehidupan. Di antaranya adalah Guru Swaddhiyaya adalah ida Sang Hyang Widhi atau Tuhan dan Guru Wisesa adalah pemerintah. Dengan mematuhi segala peraturan dan Himbauan yang diberikan oleh Guru Wisesa inilah, ketika suasana pandemi, juga merupakan wujud implementasi dari sila 1 dan ajaran Agama.

2. Pawongan

konsep pawongan, selanjutnya, manusia dan masyarakat Bali meyakini bahwa pada hakikatnya manusia itu sama sebagai makhluk dan hamba Tuhan yang berbudaya, dan, karena itu, perlu dikembangkan sikap saling asah, asih, dan asuh serta bekerja sama demi tujuan hidup manusia bersama sebagai makhluk sosial (Abdulsyani, 1987). Prinsip ini relevan dengan ajaran Hindu dalam Weda yang menjadi dasar keyakinan masyarakat Hindu Bali, yaitu ajaran tentang Tat Twam Asi yang secara harfiah berarti "ia adalah kamu juga". Dengan ajaran Tat Twam Asi ini dimaksudkan bahwa sesungguhnya semua manusia itu adalah satu dan sama sebagai makhluk Tuhan (Sukadi, 2020). Karena itu, diyakini bahwa menolong orang lain berarti menolong diri sendiri, dan menyakiti orang lain berarti menyakiti diri sendiri pula (Mantra, 1993). Dengan demikian menghagai orang lain berati sudah menghargai diri sendiri dimata sesama manusia dan juga dimata Tuhan.

Manusia Bali diharuskan membina hubungan yang harmonis antara masyarakat hindu lainnya baik umat hindu seluruh Bali, umat Hindu di desa yang dikenal dengan sebutan krama desa, atapun dengan sesama anggota keluarga atau yang sering diistilahkan dengan hubungan 
pesawitran kulewarga (Adi Adnyana, 2020). Dalam lingkup kelompok kecil dibuat organisasi yang memiliki suatu tujuan yang sama dinamakan dengan Sekaha/ Deha. Lebih lanjut dijelaskan Hubungan dalam konsep pawongan ini di Bali, tidak saja dikhususkan kepada umat se-agama semata, namun juga hubungan sosial yang baik dengan umat agama lain yang dalam tatanan struktur masyarakat adat di Bali sering disebut dengan membina hubungan dengan wong sunantara atau krama tamiu (masyarakat di luar Bali). Dengan demikian harapannya adalah terwujud kerukunan dan ketertiban antar warga dalam menjaga keutuhan dan rasa solidaritas sesuai dengan semboyan Bhineka Tunggal Ika.

Ketika pandemi Covid-19 melanda banyak masyarakat saling membantu tidak hanya lewat organisasi sosial,lembaga-lembaga pemerintah dan non pemerintah pun melalui pribadi masing-masing. Banyak ditemui poskoposko bantuan Covid-19. Aksi sosial di jalan raya dengan membagikan masker dan bahkan memberikan sumbangan sembako dan makanan. Hal ini membuktikan betapa kuatnya nilai pawongan yang dimuculkan yang mampu mengikis rasa perbedaan yang ada tanpa melihat golongan, ras dan suku yang ada. Oleh karena itu konsep opelemahan ini telah muncul sebagai pendukung implementasi pancasila terutama sila ke-II sampai dengan Sila ke-V.

\section{Palemahan}

Selanjutnya adalah konsep palemahan. Melalui konsep ini, manusia dan masyarakat Bali meyakini perlunya hubungan yang harmonis antara manusia dengan unsurunsur dan kekuatan alam lainnya. Dengan ini manusia Bali mengembangkan kesadaran bahwa manusia tidak dapat dilepaskan dari alam, karena alamlah yang memberi 
manusia kesejahteraan. Bahkan manusia Bali meyakini bahwa unsur-unsur dan kekuatan alam ini adalah saudara manusia juga seperti disimbolkan bahwa setiap bayi yang lahir selalu bersama empat saudaranya (ari-ari, air ketuban, lamas/pembungkus ari-ari dan air ketuban, dan darah) (Sukadi, 2020). Oleh karena itu kehidupan ini tidak terlepas dari alam lingkungan. Bagaikan telor dengan kuning telornya menjadi satu kesatuan yang utuh sehingga tercipta kehidupan yang harmonis.

Harapan dari konsep ini adalah manusia wajib memiliki suatu kepekaan dan kepedulian terhadap lingkungan sekitar mereka. Setiap kebutuhan manusia Bali dari masa dahulu sampai saat ini sangat bergantung dari alam, sehingga sebagai timbal balik dari ketergantungan tersebut adalah perlunya suatu kepedulian terhadap kelestarian alam tersebut sehingga apa yang diambil dari alam sebagai bagian dari pemanfaatan kebutuhan manusia mampu dikembalikan lagi ke alam dalam wujud pelestarian (Adi Adnyana, 2020). Antara manusia dengan alam selain menjadi hubungan kesatuan yang utuh tetapi juga timbul konsep sebab akibat. Oleh karena itu manusia menyadari bahawa alam menopang kehidupan manusia apabila dijaga dengan baik begitu pula sebaliknya akan mendatangkan bencana apabila dirusak kelestariannya. Ketika pandemi Covid-19 ini masih terjadi masyrakat beratu padu membersihkan lingkungannya, di setiap banjar atau kelompok warga dibentuk Tim Satgas Covid-19 dengan program salah satunya adalah kebersihan lingkungan dengan penyemprotan desinfektan, dan kesadaran memakai prokes kesehatan.

Konsep palemahan ini secara tidak tersirat mendakan implementasi dari sila-I tentang nilai-nilai Ketuhanan. Dengan menghargai dan merawat lingkungan 
adalah sebagai wujud cinta kasih dan rasa syukur kita kepada karunia Tuhan karena telah memberikan alam lingkungan hidup sebagai pendukung kehidupan manusia. Konsep palemahan dalam Tri Hita Karana dilaksanakan memalui simbol berbagai upacara yang dilaksanakan oleh umat hindu di Bali sebagai bagian dari kepekaan dan kepedulian terhadap alam dan lingkungan dalam memanifestasikan rasa syukur maysarakat bali yang beragama Hindu , seperti misalnya dengan upacara tumpek bubuh (wariga) bentuk apresiasi umat hindu akan hasil yang mereka dapatkan dari tumbuh-tumbuhan, upacara tumpek kandang sebagai bagian dari bentuk ucapan terima kasih dan kepedulian terhadap binatang atau hewan-hewan ternak yang telah mendatangkan kesejahteraan bagi kehidupan mereka. Berbagai upacara Pecauran, sebagai wujud manusia menghagai alam bawah yang tujuannya adalah mentralisir kekuan tan negatif. Hal ini pula yang dilakukan masryarakat Bali yang beragama hindu ketika awal-awal pandemi Covid-19 Melanda, sesuai dengan seruan PHDI Bali untuk melakuka upacara Pecaruan.

\section{PENUTUP}

Pada dasarnya Bali merupakan bercorak hinduistik yang menjadi dasar fasafah orang Bali adalah ajaran Tri Hita Karana maka ajaran inilah yang mendasari / core values sistem nilai-nilai kehidupan yang lainnya. Ajaran/ konsep Tri Hita Karana secara terminologi, berasal dari kata "tri", berarti tiga; "hita", berarti sejahtera, bahagia, rahayu; dan "karana", berarti sumber penyebab. Jadi, "Tri Hita Karana”, berarti tiga sumber penyebab adanya kesejahteraan, kebahagiaan, dan kerahayuan dalam hidup dan kehidupan semua makhluk ciptaan Tuhan. Idiologi Trihita Karana dan idiologi Pancasila pada kenyataanya saling 
berdampingan dan saling menguatkan dalam tatanan nilai sosial bagi masyarakat Bali, terlebih ketika situasi Pandemi Covid-19 saat ini yang sedang melanda Dunia.

\section{DAFTAR PUSTAKA}

Adi Adnyana, I Made. Refleksi nilai-nilai pancasila dalam konsep Ajaran agama hindu tri hita karana. Vidya samhita: jurnal penelitian agama. IV (2) 2020. Tersedia pada https://ejournal.ihdn.ac.id/index.php/vs/article/view/2042

Abdulsyani. 1987. Sosiologi Kelompok dan Masalah Sosial. Jakarta: Fajar Agung.

Dalem, A.A. G. R. 2007. Filosofi Tri Hita Karana dan Implementasinya Dalam Industri Pariwisata. Dalam: Kearifan Lokal Dalam Pengelolaan Lingkungan Hidup. Editor: Dalem, A. A. G. R et al., Denpasar: UPT Penerbit Universitas Udayana bekerjasama Pusat Pelatihan Lingkungan Hidup UNUD.

Kaler, IGK. 1983. Butir-butir Tercecer tentang Adat Bali. (Jilid 1 dan 2). Denpasar: Bali Agung.

Mantra, I.B. 1993. Bali: Masalah Sosial Budaya dan Modernisasi. Denpasar: Upada Sastra.

Notonagoro, 1975, Pancasila Secara Ilmiah Populer, Pantjuran Tudjuh, Jakarta.

Suasthi, I G A. dan I W. Suija, 2018. Ideologi Tri Hita Karana Membangun Keharmonisan dan Kedamaian para Ghrastha Ashram Di Desa Sukawati. Prosiding -Seminar Nasional Agama, Adat, Seni dan Sejarah Di Zaman Milenial, 2018: 235-252.

Sudarma, N. 1971. Desa Adat di Bali sebagai Lembaga Sosial Religius Berdasarkan Falsafah Tri Hita Karana. Denpasar: tidak diterbitkan 
Sukadi. 2007. Studi Etnografi Pendidikan pada SMA Negeri 1 Ubud Bali: Konsep Ajeg Bali (Hindu) Berbasis Ideologi Tri Hita Karana. Cakrawala Pendidikan, 1 (1) 2007: 1-18.

Sukadi. apakah tri hita karana dan pancasila dua ideologi yang identik? (satu kajian ontologis). Purwadita: jurnal agama dan budaya. vol. 4, no. 1, maret 2020, pp. 47-58. tersedia https://cse.google.com/cse?cx=partner-pub 7045961825256243\%3a2865325893\&q=pdf.refleksi+nilain ilai+pancasila+dalam+konsep+ajaran+agama+hindu+tri+hit a+karana

Suja, I.W. Kearifan Lokal Sains Asli Bali. Surabaya: Paramita. 


\section{URGENSI PANCASILA DALAM MENGHADAPI GLOBALISASI}

I Gede Sujana

Fakultas Keguruan dan Ilmu Pendidikan Universitas Dwijendra dalungsujana@gmail.com

\section{PENDAHULUAN}

Pada abad ke-5 SM, Socrates telah mengajarkan kepada masyarakatnya dengan sebuah pernyataan :'Kenalilah dirimu sendiri". Pernyataan tersebut saat ini masih relevan ditanyakan kembali kepada kita semua, baik sebagai manusia maupun sebagai Bangsa Indonesia. Di tengah-tengah eforia reformasi dan globalisasi, sebagian dari kita (bangsa Indonesia) telah kehilangan jati diri baik sebagai manusia maupun sebagai bangsa. Kita telah terjebak pada gaya hidup yang pragmatis-ekonomi, dengan meniru budaya Barat (westernisasi) secara parsial tanpa memahami pembahasannya secara utuh. Gaya hidup hedonis-materialis yang terus menerus dipamerkan oleh kaum kapitaslis melalui berbagai media massa baik cetak maupun elektronik, telah mempengaruhi masyarakat kita. Berbagai kenikmatan jasmani yang ditawarkan oleh kaum kapitalis telah membentuk pasar yang sangat potensial di masyarakat golongan menengah dan para remaja. Perilaku dan gaya hidup para remaja mulai dari yang hidup di metropolitan 
sampai di perdesaan telah menunjukkan pola hidup yang konsumtif, dengan meniru gaya hidup materialistis. Di kalangan mahasiswa, handphone bukan lagi sebagai sarana komunikasi yang efektif, tetapi telah dianggap sebagai simbol status sosial. Sementara uang saku yang diberikan oleh orang tua kadang tidak mencukupi untuk membiayai gaya hidup mereka yang sangat konsumtif. Akibatnya muncul berbagai perilaku yang menyimpang dengan mengabaikan norma kesopanan, norma moral serta norma agama yang selama ini diagungkan oleh bangsa Indonesia.

Berbagai tindak kriminalitas yang dilakukan oleh para remaja setiap hari bisa kita baca di berbagai media massa atau kita lihat melalui media elektronik. Rata-rata mereka yang terlibat dalam tindak kriminal atau narkoba justru mereka yang berusia remaja dan sebagian adalah para mahasiswa yang sebenarnya belum mempunyai beban keluarga, kecuali kebutuhan dirinya sendiri. Tingkat konsumsi yang tinggi sebagai konsekwensi dari gaya hidup mereka yang tidak diimbangi dengan kemampuan dan kemauan untuk bekerja (berproduksi), telah menghasilkan sikap mental penerabas, yang cenderung malanggar norma-norma sosial, hukum maupun agama. Para elit birokrasi dan elit politikpun juga banyak yang terjebak pada pandangan hidup hedonis-materialis, sehingga cenderung menyalahgunakan kekuasaan hanya untuk mengejar kesenangan duniawi, tanpa mengindahkan rambu-rambu moral dan agama. Hal ini bisa dilihat dengan semakin maraknya KKN di era otonomi ini. Di era reformasi KKN bukan semakin berkurang, tetapi semakin berkembang dan terbuka. Menurut beberapa pengamat, di era reformasi dan otonomi, KKN bukan hanya terjadi dikalangan eksekutif tetapi juga di kalangan legislatif. Tidak hanya terjadi di pusat, tetapi juga di daerah-daerah. Hal ini juga dibuktikan banyaknya anggota DPR dan kepala daerah yang terlibat dalam kasus korupsi.

Di sisi lain, pameo bangsa Indonesia adalah bangsa yang beradab, ramah dan suka menolong, semakin kabur dari realitas 
sosial. Berbagai tindak kekerasan yang terjadi di kota-kota besar, seperti Jakarta, Surabaya, Medan, serta berbagai kerusuhan yang terjadi di berbagai daerah seperti Poso, Maluku, Kalimantan merupakan realita yang menegasikan pameo sebagai bangsa yang ramah dan beradab. Bahkan di mata internasional, Indonesia selain dianggap sebagai negara yang korup, juga negara yang banyak melakukan pelanggaran Hak Asasi Manusia, semua menjadi catatan buruk Indonesia di dunia internasional. Citra bangsa Indonesia di dunia internasional semakin merosot. Hal ini tentu sangat memprihatinkan bagi kita semua, sebagai bangsa Indonesia. Berbagai paparan realita di atas, kiranya harus kita renungkan kembali dengan bertanya kepada diri kita sendiri, baik sebagai manusia maupun sebagai bangsa. Pertanyaan mendasar antara lain adalah : manusia macam apa aku ini?, dimana nilai-nilai Pancasila yang selama ini kita agungkan sebagai jiwa dan kepribadian bangsa?, bagaimana dengan pendidikan moral (agama dan kewarganegaraan) yang selama ini kita lakukan?, apakah ada kesalahan, sehingga belum mampu menghasilkan insan-insan yang berakhlaq mulia, berperilaku yang santun dan ramah?

\section{PEMBAHASAN}

\subsection{Lunturnya Nasionalisme}

Ketika bangsa Indonesia memproklamirkan kemerdekaan pada tanggal 17 Agustus 1945, mempunyai tantangan berat, karena yang dibangun bukan hanya Negara, tetapi juga bangsa (nationstate). Pembangunan negara ditandai dengan perubahan politik, dari suatu bangsa terjajah menjadi suatu negara merdeka yang bebas untuk mengatur diri sendiri dalam negara kesatuan yang berbentuk Republik. Bagi bangsa-bangsa yang terjajah, ideologi nasionalisme merupakan pembangkit semangat untuk melepaskan diri dari keterhinaan bangsa-bangsa penjajah. Dengan kesadaran bahwa semua bangsa mempunyai kedudukan dan harkat yang 
sama, termasuk hak untuk merdeka, membangkitkan semangat untuk melepaskan diri dari cengkeraman penjajah. Bagi bangsa Indonesia, upaya untuk memperoleh hak atas kemerdekaan dilakukan dengan perjuangan yang banyak menelan korban yang berupa harta benda maupun jiwa.

Perjuangan mengusir penjajah bukan hanya menelan korban jiwa dan harta benda, tetapi juga membutuhkan waktu yang panjang. Hampir setiap daerah atau suku melakukan perlawanan terhadap penjajah. Namun perjuangan yang bersifat lokal (kedaerahan) tersebut mudah dipatahkan oleh penjajah, sehingga tidak membawa hasil. Menyadari perjuangan yang bersifat kedaerahan tersebut, kemudian memunculkan kesadaran untuk bersatu. Mereka mencoba untuk menghilangkan sifat-sifat kedaerahan dan dengan sadar mengikatkan diri sebagai satu bangsa. Ikrar sebagai satu bangsa Indonesia dicetuskan dalam Konggres Pemuda II tahun 1928, yang kemudian dikenal dengan Sumpah Pemuda. Rasa senasib sepenanggungan sebagai bangsa yang terjajah, dan keinginan untuk hidup yang lebih sejahtera itulah yang menjadi salah satu pengikat rasa kebangsaan Indonesia. Mereka menghilangkan perbedaan sebagai suatu bangsa yang memang berbeda. Paling tidak mereka meninggalkan egoisme kedaerahan untuk membagun suatu bangsa (nation), yaitu bangsa Indonesia berdasarkan kontrak yang mereka buat sendiri. Kehidupan lama yang tersusun berdasar askripsi status dengan cepat digantikan oleh organisasi kehidupan baru yang lebih tersusun berdasarkan kontrak-kontrak yang dibuat oleh dan untuk para warga sendiri (Soetandyo W., 1999).

Suku-suku yang terjajah menyadari bahwa untuk melawan pnejajah yang memiliki kelebihan dalam hal teknologi dan persenjataan, mereka harus menyatukan diri. Perlawanan yang dilakukan secara lokal (kesukuan) tidak mampu menandingi kekuatan penjajah yang meskipun sedikit jumlahnya, tetapi memiliki persenjataan yang lebih modern. Untuk itu, nasionalisme 
merupakan suatu semangat dan harapan dari berbagai suku yang merasa mempunyai nasib yang sama sebagai komunitas (suku) yang terhina oleh penjajah.

Konsep bangsa (nation) yang semula bersifat ideologis untuk mempersatukan suku-suku yang terjajah telah berubah menjadi wacana kekuasaan, bahkan sekarang sudah menjadi cognisi belaka. Pada awalnya, pengertian bangsa mengacu kepada kelompok masyarakat karena sejarah yang sama, senasib sepenanggungan menyatu melintasi batas-batas kedaerahan (lokalisme) dalam rangka mewujudkan kesejahteraan bersama. Nasionalisme merupakan ideologi untuk melawan kolonialisme. Kesamaan sejarah, terutama pengalaman sebagai masyarakat yang terjajah menjadi faktor utama lahirnya suatu bangsa. Sebagaimana yang dikatakan Ernst Renan bahwa sejarah menjadi faktor utama dalam nasionalisme/paham kebangsaan. Paham kebangsaan sebagai ideologi untuk melawan penjajahan, inilah yang kemudian melahirna Negara-Bangsa (nation-state). Paham kebangsaan yang ada di Indonesia juga didasarkan oleh cerita-cerita masa lalu, baik sebagai bangsa yang terjajah, maupun oleh sejarah kerajaan, terutama Majapahit. Namun paham negara-bangsa (nation-state) pada era global telah berakhir (Kinchi Ohmae : The End of The Nation State). Kebangsaan seseorang tidak lagi ditentukan oleh tempat tinggalnya, tetapi lebih ditentukan oleh cognisinya. Sebagaimana yang dikatakan oleh Anderson Imagined communities, bahwa kebangsaan seseorang lebih ditentukan oleh bagaimana ia mengkonstruksi dirinya, bukan ditentukan oleh tempat tinggal dan kelahirannya. Hal ini semakin dimungkinkan dengan semakin mudahnya mobilitas seseorang di era global. Sekarang persoalan nasionalisme, bukan lagi konflik antar negara dengan negara (negara penjajah dan terjajah), tetapi lebih pada koflik di dalam negeri sendiri. Hal ini juga yang menyebabkan mudahnya masyarakat yang terpapar radikalisme dan terorisme. Persoalan nasionalisme bukan lagi berkaitan dengan kesamaan 
diantara bangsa, tetapi lebih menekankan pada kesamaan diantara semua warga negara.

Ideologi nasionalisme menurut Sartono (2003) di dalamnya meliputi lima prinsip, yakni kesatuan (unity), kemerdekaan (liberty), kesamaan (equality), kepribadian (personality), dan prestasi (performance). Kesatuan, kemerdekaan, dan kesamaan merupakan prinsip utama untuk membangun bangsa, terutama bangsa-bangsa yang majemuk seperti bangsa Indonesia. Diantara suku-suku yang membentuk bangsa (nation) harus dilandasi oleh kemauan untuk bersatu (mengikatkan diri) dengan suku-suku lain atas dasar kemerdekaan dan kesamaan. Meskipun mereka telah mengikatkan diri dalam satu kesatuan sebagai bangsa, mereka tetap mempunyai kemerdekaan untuk mengembagkan identitas kulturalnya (lokal). Mereka juga harus mempunyai kesamaan, baik dalam bidang politik, ekonomi dan hukum agar tidak ada dominasi mayoritas atas minoritas, atau dominasi minoritas atas mayoritas. Hal ini telah ditegaskan dalam UUD 1945 sebagai kesepakatan nasional.

Sementara kepribadian (personality) dan prestasi (performance) merupakan hal yang harus dibangun dan diperjuangkan oleh bangsa tersebut. Sudah barang tentu keberhasilan membangun identitas diri (personality) sebagai suatu bangsa yang berbeda dengan bangsa lain akan semakin memperkokoh kesatuan diantara mereka. Begitu pula keberhasilan mewujudkan suatu prestasi (kelebihan), apakah di bidang politik, ekonomi atau ilmu dan teknologi akan semakin menambah kebanggan sebagai suatu bangsa sekaligus memperkokoh kesatuan bangsa. Bagi bangsa Indonesia, pembangunan identitas diri secara formal telah dirumuskan dalam Pancasila. Menurut Notonagoro, kausa material Pancasila adalah adat dan budaya bangsa Indonesia sendiri. Nilai-nilai Pancasila digali dari adat dan budaya bangsa yang telah ada dan menjadi pedoman perilaku mereka. Nilai-nilai 
tersebut sekaligus juga menjadi pengikat dari berbagai suku, sehingga Pancasila jug sering disebut pemersatu bangsa.

Pancasila bagi bangsa Indonesia bukan hanya dijadikan sebagai Dasar Negara yang mendasari penyelenggaraan kenegaraan, tetapi juga dijadikan sebagai pandangan hidup yang memberi penerang (light star) (Dardji Darmodiharjo : 1999) dan pedoman bagi setiap orang dalam berucap, bersikap dan bertindak dalam pergaulan diantara sesama bangsa maupun dengan bangsa lain. Manifestasi Pancasila sebagai pandangan hidup ini menyebabkan Pancasila juga menjadi keprobadian bangsa. Sebagai pandangan hidup, Pancasila telah dijabarkan dalam rincian yang lebih operasional, yaitu dalam butir-butir Pedoman Penghayatan dan Pengamalan Pancasila (P-4). Meskipun kemudian Ketetapan tentang pembudayaan P-4 (Tap MPR No.II/MPR/1978) tersebut kemudian dicabut, nilai-nilai (butir-butirnya) sebenarnya tetap relevan dijadikan pedoman dalam berucap, bersikap, dan bertindak bagi setiap warga negara Indonesia.

\subsection{Hilangya Jati Diri Bangsa Indonesia}

Menghadapi globalisasi yang ditandai dengan homogenisasi, dibutuhkan kepribadian yang jelas sebagai identitas diri dari setiap bangsa. Globalisai sebagai hasil dari kemajuan teknologi komunikasi dan transportasi telah memudahkan setiap orang untuk berinteraksi dengan menghilangkan dimensi ruang dan waktu. Globalisasi telah menghilangkan batas-batas kenegaraan, yang memungkinkan setiap orang untuk berinteraksi dengan siapa saja dalam waktu yang singkat. Meskipun demikian globalisasi menurut Robertson juga mengandung bahaya, sebab mengarah pada pandangan homogenitas dan hegemoni budaya. Budayabudaya yang besarlah (budaya dan negara-negara yang mempunyai kekuatan hegemoni seperti Amerika) yang dianggap baik. Cara pandang yang demikian akan semakin melemahkan ekonomi negara-negara berkembang, karena tidak mempunyai kekuatan 
tawar. Negara-negara berkembang akan menjadi konsumen budaya dari negara-negara maju (sebagai contoh Macdonalisasi). Untuk itu Robertson (1995) menawarkan konsep glokalisasi, yang tetap mempertahankan budaya lokal di tengah proses global.

Persoalannya sekarang, bangsa Indonesia justru telah kehilangan jati diri. Bangsa indonesia sekarang cenderung maninggalkan nilai-nilai Pancasila. Kondisi seperti ini telah merisaukan para perintis kemerdekaan, sehingga Dewan Harian Daerah (DHD) 45 Provinsi Jawa Timur telah mempolepori untuk dirumuskannya kembali jati diri bangsa, dengan melibatkan berbagai perguruan tinggi di Surabaya. Rumusan jati diri bangsa yang diprakarsai oleh DHD 45 Jawa Timur sekarang telah tersusun dalam sebuah buku yang berjudul : Pembangunan Jati Diri Bangsa Indonesia. Hilangnya jati diri bangsa ini disebabkan bangsa Indonesia telah meninggalkan nilai-nilai Pancasila, dan terjebak pada nilai-nilai materialistis, pragmatis, dan hedonis. Perubahan sikap, cara pandang dan perilaku ke arah sikap yang pragmatis, cara pandang yang materialistis, dan perilaku yang hedonis tanpa disertai dengan perubahan etos kerja dan profesionalisme dalam produktivitas telah menyebabkan bangsa Indonesia mengalami kemerosotan moral. Sebagian elit bangsa dan warga bangsa telah masuk dalam budaya Korupsi, Kolusi dan Nepotisme (KKN), yang telah menghancurkan sendi-sendi kehidupan berbangsa dan bernegara.

Semakin maraknya KKN sebagai akibat dari kemerosotan moral inilah yang menjadi salah satu faktor penyebab terpuruknya perekonomian bangsa Indonesia. Perilaku KKN bukan hanya terjadi di kalangan birokrat, tetapi juga sudah dilakukan oleh para wakil rakyat. KKN bukan lagi terjadi di Pusat, tetapi juga sudah sampai ke daerah-daerah. Pasca reformasi, KKN khususnya korupsi bukan semakin berkurang, tetapi justru semakin bertambah. Dengan diberlakukannya UU Nomor 32 tahun 2004 tentang pemerintahan daerah, KKN justru semakin meluas sampai ke 
daerah-daerah dan ke lembaga-lembaga legislatif. Semakin meluasnya lembaga yang terlibat dalam Korupsi menyebabkan Indonesia termasuk dalam Negara yang terkorup di dunia. Indonesia termasuk 6 negara yang terkorup dari 132 negara yang mempunyai tingkat korupsi tinggi.

Semakin terpuruknya perekonomian Indonesia diantaranya disebabkan lunturnya nasionalisme, tidak dimilikinya pandangan ke depan (visioner) dan hilangnya idealisme hampir sebagian besar masyarakat, khususnya para elit. Sebagian para elit kita terebab kepada pemikiran saat ini (aji mumpung). Hal ini bisa dilihat dari perilaku sebagaian anggota DPR dan DPRD yang mengindikasikan terlibat dalam korupsi atau money politic dalam pemilihan kepala daerah. Bagi sebagian orang, menjadi anggota DPR atau DPRD tidak lagi memperjuangkan kepentingan rakyat atau konstituennya, tetapi justru untuk mencari keuntungan pribadi saat ini. Sementara idealisme yang menjadi pencerah dalam setiap langkah telah hilang.

\subsection{Prestasi Sebagai Perekat Rasa Kebangsaan.}

Kondisi yang demikian bukan hanya semakin mempersulit pemulihan ekonomi, dan tidak kondusif dalam pembangunan bangsa, tetapi juga berpengaruh pada posisi dan pergaulan Indonesia di tingkat internasional. Kepercayaan bangsa-bangsa lain terhadap Indonesia sebagai modal pembangunan semakin menurun. Menurunnya kepercayaan bangsa-bangsa lain terhadap Indonesia juga mempengaruhi citra bangsa Indonesia di hadapan bangsabangsa lain di dunia. Sementara prestasi yang bisa dibanggakan oleh bangsa Indonesia sangat sedikit. Dalam bidang ilmu dan teknologi, hanya sedikit temuan yang dihasilkan oleh putra-putri Indonesia, seperti Jembatan "Cakar Ayam" oleh Ir. Haryatno, "Sosro Bahu" oleh Ir. Cokorda, teori retak (crack theory) oleh Habibie. Prestasi dalam bidang olah raga, khususnya bulu tangkis yang pernah menjadi kebanggan bangsa Indonesia dalam 
percaturan dunia, kini telah menurun. Dalam pesta-pesta olah raga di tingkat Asia maupun Asia Tenggara, Indonesia sudah tidak selalu menjadi juara umum. Prestasi Indonesia di bidang olah raga sudah sering tertimggal oleh Cina, Thailand, Malaysia maupun Vietnam.

Tidak adanya prestasi dan kebanggaan yang dimiliki bangsa Indonesia menyebabkan lemahnya rasa kebangsaan atau nasionalisme dari setiap warga negara Indonesia. Di sisi lain, nilainilai Pancasila yang semula menjadi pengikat dari berbagai suku dan sekaligus sebagai acuan dalam kehidupan berbangsa dan bernegara juga sudah banyak ditinggalkan oleh elit-elit bangsa, sehingga keterikatan mereka sebagai satu bangsa menjadi semakin lemah. Kondisi yang demikian sangat rentan terjadinya perpecahan diantara sesama warga bangsa.

Harus diakui banhwa Pancasila merupakan suatu prestasi bangsa Indonesia dalam bidang pemikiran (filosofis) yang bukan hanya membanggakan, tetapi juga dapat mempersatukan bangsa Indonesia. Pancasila sebagai filsafat negara merupakan hasil pemikiran yang mendalam dan mendasar dalam membangun suatu bangsa yang sangat plural. Pancasila sebagai suatu filsafat menurut Notonagoro (1999) bukan hanya mengandung kebenaran secara ilmiah dan filosofis, tetapi juga mengandung kebenaran religius. Nilai-nilai Pancasila, selain bersumber dari kodrat manusia juga merupakan bagian dari ajaran agama. Sementara susunan Pancasila yang menempatkan Ketuhanan pada sila pertama dan keadilan sosial pada sila kelima mengandung kebenaran ilmiah berdasarkan hukum kausalitas. Itulah sebabnya, Pancasila juga mampu mempersatukan bangsa Indonesia yang majemuk, karena nilai-nilai Pancasila merupakan kebutuhan kodrat dari setiap manusia.

Namun sekarang, kepercayaan yang dibangun oleh berbagai suku atas dasar kesamaan nasib sebagai bangsa yang terjajah menjadi semakin luntur, ketika terjadi ketidakadilan dalam pembangunan. Keinginan untuk bersatu sebagai suatu bangsa 
dalam suatu negara dilandasi oleh adanya keinginan untuk mencapai kehidupan yang lebih baik dan sejahtera. Semua itu dilandasi oleh perasaan senasib dan sepenanggungan, sama-sama sebagai bangsa yang terjajah. Dengan perasaan tersebut mereka membangun harapan bersama akan terwujudnya kehidupan yang lebih adil dan sejahtera. Semua itu tentu dilandasi oleh sikap untuk saling percaya, baik antar sesama suku maupun terhadap elit pemimpin. Rasa saling percaya diantara sesama warga bangsa, kini kian menurun. Berbagai konflik antar sesama warga bangsa, baik antar suku maupun antar golongan semakin sering terdengan dan terjadi. Munculnya banyak partai politik saat ini juga mengindikasikan semakin lemahnya kepercayaan diantara sesama warga bangsa. Diantara para elit politik sudah tidak saling percaya, sehingga mereka berlomba-lomba membentuk partai politik baru sebagai kendaraan untuk meraih kekuasaan. Masing-masing membentuk kelompok berdasarkan kepentingan kekuasaan sesaat dan mengutamakan kepentingan kelompoknya. Akibatnya, sering terjadi konflik politik dengan mengorbankan kepentingan rakyat yang seharusnya dilindungi hanya untuk mengejar kekuasaan semata.

\subsection{Merubah Paradigma Berpikir}

Munculnya berbagai konflik, baik konflik sosial maupun konflik politik lebih disebabkan oleh paradigma berfikir bangsa. Di masyarakat, perbedaan cara berfikir dan cara pandang terhadap sesuatu sering menjadi sumber konflik sosial maupun konflik politik. Berbagai konflik antar etnis yang terjadi di berbagai daerah merupakan indikasi bahwa perbedaan nilai dan norma dengan mudah dijadikan sebagai sumber konflik. Perbedaan nilai dan norma tersebut sering dimanfaatkan oleh pihak-pihak yang tidak bertanggungjawab (provokator) untuk mencapai kepentingannya dengan menciptakan konflik sosial maupun konflik politik.

Mudah terjadinya konflik diantara suku yang berbeda budaya, meskipun ada yang memprovokasi, sebenarnya juga 
disebabkan oleh paradigma berfikir bangsa kita yang diagonalistik. Hampir sebagian besar bangsa kita berfikir diagonalistik. Mereka memandang bahwa perbedaan pendapat itu adalah "konflik" antara benar dan salah. Jika mereka berbeda pendapat, masing-masing berusaha membenarkan pendapatnya sendiri, dan berusaha menyalahkan pendapat yang lain, sebab bila yang lain tidak disalahkan, mereka menganggap bahwa pendapatnya yang salah. Untuk itu, masing-masing dengan berbagai cara (membangun logika) berusaha untuk menyalahkan pendapat orang lain dan membenarkan pendapatnya sendiri.

Paradigma berpikir diagonalistik ini menimbulkan otoritarian pemikiran. Setiap orang berusaha memaksakan pendapatnya sebagai suatu kebenaran dan tidak mau menerima pemikiran orang lain yang berbeda dengan pemikirannya. Pola pikir diagonalistik ini terlihat dalam sikap para elit politik maupun elit birokrasi yang cenderung tidak mau menerima kritik dan saran dari orang lain. Dalam pengambilan keputusanpun mereka cenderung otoriter, tidak mau memperhatikan saran dan pendapat orang lain. Bahkan mereka mensikapi kritik dan saran sebagai "musuh" yang harus dihancurkan.

Paradigma berpikir diagonalistik ini bukan hanya terjadi di kalangan elit, tetapi juga sampai pada kalangan bawah. Masyarakat kita tidak atau belum bisa menerima adanya perbedaan pendapat. Perbedaan pendapat, ideologi, agama, suku, dan budaya sering menjadi sumber konflik sosial maupun politik. Cara berfikir yang diagonalistik di kalangan lapisan bawah ini akan menjadi sangat rentan terjadinya konflik, bila ada yang memprovokasi. Paradigma berpikir diagonalistik menjadi sumber konflik yang sangat potensial pada saat menjelang pemilu yang melibatkan banyak partai politik. Masing-masing pendukung partai akan menjadikan pendukung partai lainnya sebagai lawan yang harus dihancurkan, termasuk dengan kekerasan. 
Paradigma berpikir diagonalistik ini jelas tidak sesuai dengan Pancasila, yang menjunjung tinggi nilai-nilai demokratis dan semangat musyawarah dalam pengambilan keputusan. Di dalam demokrasi terdapat pengakuan adanya perbedaan pendapat. Demokrasi bukan hanya mengakui, tetapi juga menjunjung tinggi adanya perbedaan pendapat. Perbedaan pendapat bukan hal yang tabu, namun justru menjadi motor dari dinamika sosial. Oleh karena itu, di dalam demokrasi, perbedaan pendapat diberi tempat dan dipelihara sebagai kontrol sosial dan politik.

Paradigma berpikir diagonlistik ini harus diganti dengan paradigma berfikir alternatif, yang mengakui dan menerima adanya perbedaan. Perbedaan pendapat bukanlah dipandang sebagai pertentangan antar benar dan salah, tetapi dilihat sebagai alternatif, antara benar-benar, salah-salah atau benar dan salah yang tidak saling bertentangan. Paradigma berpikir alternatif inilah yang dapat dikatakan bahwa perbedaan pendapat itu adalah rahmat. Dengan pola pikir alternatif ini, konflik sosial maupun politik bisa dihindari, atau paling tidak bisa dikurangi.

Selain paradigma berpikir diagonalistik, yang sering menjadi sumber konflik dalam masyarakat adalah sikap berburuk sangka (negatif thinking). Sikap berburuk sangka ini juga menghinggapi sebagian besar cara pandang masyarakat kita. Masyarakat kita lebih suka melihat kekurangan dan keburukan orang lain daripada melihat kelebihan dan kebaikannya. Sikap yang demikian tentu akan menimbulkan, paling tidak menjadi benih konflik dalam interaksi sosial.

Sikap berburuk sangka ini bukan hanya menjadi benih konflik sosial maupun politik, tetapi juga menyebabkan kita tidak bisa maju. Dengan sikap berburuk sangka (negatif thinking), orang tidak mau belajar dari orang lain, karena merasa dirinyalah yang paling benar, paling baik, dan paling tahu. Sikap yang demikian ini orang menjadi sombong dan congkak. Kesombongan dan kecongkakan ini bukan hanya bertentangan dengan nilai-nilai 
Pancasila, khususnya sila kemanusiaan tetapi juga bertentangan dengan ajaran agama.

Sikap berburuk sangka ini juga menyebabkan orang tidak lagi berani mengambil tanggung jawab atas perbuatan yang mereka lakukan. Orang cenderung mencari-cari kesalahan orang lain. Dampak sikap yang demikian adalah munculnya budaya "kambing hitam" untuk menutupi kesalahan yang dilakukan. Budaya seperti inilah yang menurut Mochtar Lubis (2001) disebut dengan budaya hipokrit atau munafik.

Budaya suka mencari "kambing hitam" dan sikap munafik ini dapat melahirkan fitnah, provokasi, atau adu domba yang menjadi sumber konflik diantara sesama warga bangsa. Berbagai konflik antar warga bangsa ini banyak disebabkan oleh fitnah adu domba dan provokasi. Tingkat pendidikan masyarakat kita yang masih rendah sangat rentan terhadap fitnah dan provokasi. Mereka gampang difitnah dan diprovokasi dengan berbagai isu yang terkadang tidak masuk akal. Paradigma berpikir negatif ini juga menimbulkan ketidakpercayaan (distrust), khususnya terhadap elit politik. Hilangnya kepercayaan masyarakat terhadap elit politik, menyebabkan elit politik kehilangan kewibawaan, sehingga tidak mampu mengelola berbagai konflik yang terjadi di masyarakat.

Sikap berburuk sangka (negatif thinking) harus diganti dengan sikap berbaik sangka (positif thinking). Dengan paradigma positif thinking (berbaik sangka) jelas akan menghindari munculnya konflik sosial maupun konflik politik diantara sesama warga bangsa. Dengan sikap berbaik sangka juga akan tumbuh rasa kemanusiaan dan penghargaan terhadap perbedaan dan kepentingan orang lain.

Budaya lain yang juga sering menjadi penghambat kemajuan bangsa adalah paradigma berpikir "sebab". Paradigma berpikir ini menyebabkan kita sulit untuk maju dan tidak mempunyai prestasi yang membanggakan. Paradigma berpikir sebab berkaitan dengan sikap berburuk sangka yang melahirkan 
budaya "kambing hitam". Paradigma berpikir sebab ditandai dengan tidak adanya perencanaan ke depan, atau tidak dimiliknya Visi. Paradigma berpikir sebab tidak hanya terjadi di kalangan bawah, tetapi juga pada elit politik dan birokrasi. Hal ini bisa dilihat dalam perencanaan pembangunan. Berbagai kebijakan pembangunan kurang disertai analisis dampak kebijakan. Artinya setiap kebijakan tentu akan menimbulkan dampak negatif yang harus diantisipasi dengan kebijakan lain, agar dampak negatif tersebut dapat diminimalisir. Berbagai peristiwa seperti banjir, tanah longsor yang terjadi sebenarnya sudah bisa diduga sebelumnya, sebagai akibat penebangan hutan di berbagai wilayah pegunungan atau di daerah hulu.

Pada masyarakat lapisan bawah, paradigma berpikir sebab dapat muncul dalam bentuk sikap yang pragmatis. Mereka bertindak dulu baru berpikir, bukan berpikir dulu baru bertindak. Segalanya disikapi dengan pemikiran yang pragmatis, yang hanya mengejar dan memikirkan manfaat sesaat, tanpa berpikir akibatnya untuk jangka panjang. Paradigma berpikir yang demikian juga sangat potensial menimbulkan konflik kebangsaan di masa depan. Perilaku yang dilandasi dengan paradigma berpikir sebab, akan meninggalkan "bom waktu" yang tidak bisa dipikirkan sebelumnya.

Paradigma ini harus dirubah ke paradigma berpikir "akibat", artinya perilaku dan tindakan atau kebijakan harus dipikirkan akibat yang akan ditimbulkan oleh perilaku, tindakan atau kebijakan tersebut. Dengan paradigma berpikir akibat, masyarakat dibiasakan untuk berpikir jauh ke depan (visioner), dengan membuat suatu perencanaan. Dalam paradigma berpikir akibat kita dibiasakan untuk menyusun perencanaan dan berpikir sebelum melakukan sesuatu. Kita juga dibiasakan menganalisis berbagai tantangan yang akan dihadapi dan mempersiapkan diri menghadapinya. Paradigma berpikir "akibat" inilah yang menyebabkan bangsa meraih kemajuan di berbagai bidang karena 
mereka sudah mengantisipasi dan mempersiapkan diri terlebih dahulu dalam menghadapi tantangan masa depan.

\subsection{Konstruksi Diri}

Selain lunturnya nasionalisme dan paradigma berpikir, pemahaman tentang siapa dan apa manusia juga menjadi hal yang sangat penting dalam pembangunan jati diri bangsa. Meskipun semua orang menyebut dirinya sebagai manusia, jika ditanya siapa dan apa manusia, mereka akan sulit unruk menjawab seketika dan sama. Masing-masing individu akan mencoba untuk berpikir dan kemudian baru memberi jawaban sesuai dengan tingkat pengetahuan dan pemahaman masing-masing. Bahkan kalau ditanya untuk apa hidup, ini masing-masing orang juga akan memberi jawaban yang berbeda. Perbedaan mengenai pandangan tentang siapa dan apa serta apa tujuan hidup inilah yang menyebabkan munculnya perilaku (kepribadian) yang berbeda. Bahkan ada orang yang tidak peduli tentang apa dan siapa serta apa tujuan hidup ini. Mereka hidup layaknya binatang yang hanya mengejar kesenangan yang bersifat jasmaniah, seperti makan, seks dan hal-hal yang bersifat material dan duniawi.

Memang tidak semua orang mampu memahami hakekatnya sebagai manusia, karena untuk memahami dan menemukan konsepsi (hakekat) siapa dan apa manusia serta apa tujuan hidup ini membutuhkan perenungan yang mendalam dengan menggunakan akal sehat. Manusia yang oleh Aristoteles disebutkan sebagai animal rasional tidak jarang menggunakan akalnya sebagai instrumen untuk memahami kebenaran, tetapi justru menggunakan akalnya untuk membenarkan dirinya. Akibatnya mereka gagal memahami kebenaran hakekatnya sebagai manusia dan tujuan hidup ini.

Sebenarnya bangsa Indonesia melalui salah seorang putra terbaiknya (Notonagoro) telah menemukan tentang apa dan siapa manusia. Konsepsi Notonagoro tentang manusia tersebut, sebenarnya sudah lama menjadi acuan bagi pembangunan nasional 
dan para dosen Pancasila, namun karena pemahaman yang kurang mendalam, akibanta transmisi pengetahuan dan pemahaman tersebut kurang mengena (dapat membentuk pribadi yang mulia). Padahal, konsepsi Notonagoro tentang manusia, meskipun belum sempurna namun sudah cukup memadai untuk membentuk pribadi yang mulia jika dipahami secara benar.

Bertolak dari konsepsi Notonagoro, dapat dikatakan bahwa dalam diri manusia terdiri dari unsur positif dan unsur negatif. Artinya di dalam diri manusia ada kebaikan dan ada kejahatan atau manusia itu setengan setan dan setengah malaikat. Untsur positif manusia terletak pada unsur jiwa (akal, rasa dan karsa), sifat sosial dan mahluk Tuhan. Sedangkan unsur negatifnya terletak pada unsur raga (benda mati, tumbuhan dan sifat kebinatangan), sifat individu dan mahluk pribadi. Bila seseorang lebih menonjolkan dan mengikuti unsur-unsur negatifnya, maka akan menjadi pribadi yang buruk. Seseorang yang mementingkan unsur raga, akan cenderung seperti binatang. Hidupnya hanya untuk makan, bukan makan untuk hidup. Orang yang lebih menonjolkan unsur raga, akan cenderung bersifat materialistis dan menjadikan materi sebagai ukuran nilai dirinya.

Memang setiap individu, termasuk manusia membutuhkanmakan, namun dalam mencari makan dan cara makan manusia harus menggunakan etika, dengan mempertanyakan apakah yang kita makan itu sehat atau tidak, dan ketika kita makan apakah orang di sekitar kita kelaparan atau tidak. Inilah gunanya akal untuk berpikir, rasa untuk merasakan apa apa yang dirasakan oleh orang lain, dan kehendak yang mendorong kita untuk berbuat baik.

Demikian halnya jika seseorang yang hanya mementingkan sifat individunya tanpa diimbangi oleh sifat sosial akan menjadi pribadi yang egois, yang selalu memandang orang lain sebagai "musuh", ancaman yang harus dibinasakan. Mereka cenderunng mencari-cari kesalahan orang lain, sehingga suka 
menebar konflik dan fitnah. Hal ini berbeda dengan orang yang lebih menonjolkan sifat sosialnya, ia akan melihat orang lain sebagai kawan, bukan sebagai lawan. Mereka juga cenderung melihat kelebihan orang lain, dan suka menolong oranglain, karena mereka menyadari bahwa dirinya sama dengan yang lain dan tidak ada artinya hidup tanpa orang lain.

Unsur negatif yang lainnya adalah sebagai mahluk pribadi. Sebagai mahluk pribadi, oleh Tuhan manusia memang diberi kebebasan, namun jika kebebasan tersebut tidak diserta tanggungjawab, maka akan menimbulkan anarkisme. Orang seperti ini ada kecenderungan melupakan kewajibannya kepada Tuha. Mereka beranggapan bahwa hidup akan berakhir dengan kematian, sehingga mereka tidak harus mempertanggungjawabkan perbuatannya. Mereka lupa bahwa kebebasan yang diberikan oleh Tuhan itu harus dipertanggungjawabkan nanti di akhirat (setelah mati). Sebenarnya bila konsep Notonagoro dipahami dengan benar, maka akan mampu membentuk pribadi yang mulia. Salah satu tugas yang diemban oleh Mata Kuliah Pengembangan Kepribadian adalah membentuk pribadi-pribadi yang mulia dengan cara menanamkan hakekat manusia. Sebab "manusia" pada hakekatnya merupakan tujuan dari setiap orang. Ketika setiap orang menyebut dirinya sebagai manusia, sebenarnya dia sedang berproses menuju dan mengkonstruksi dirinya sebagai manusia. Dalam berproses mengkostruksi diri, konsep Notonagoro paling tidak untuk sementara dapat dijadikan rujukan.

\subsection{Membangun Jati Diri Bangsa}

Bertolak dari kondisi bangsa serta tantangan yang dihadapi, yang harus dilakukan bangsa Indonesia agar mampu bersaing dan duduk sejajar dengan bangsa-bangsa lain adalah meningkatkan kualitas sumber daya manusia, baik kualitas moral, kualitas sosial, dan kualitas profesional. Kualitas moral dan kualitas sosial berkaitan dengan jati diri bangsa. Sebagaimana yang dikemukakan oleh Robertson, bahwa dalam globalisasi yang 
ditandai dengan homogenisasi tetap diperlukan jati diri bangsa sebagai identitas pergaulan antar bangsa. Jati diri bangsa Indonesia yang sudah mulai luntur akibat arus globalisasi menyebabkan bangsa Indonesia kehilangan kendali dan arah membangun masa depan. Oleh karena itu, pembangunan jati diri bangsa perlu mendapat perhatian yang serius.

Pembangunan jati diri bangsa bukan hal yang instan, melainkan membutuhkan waktu yang panjang dan dimulai sejak dini dan dilakukan secara kontinu. Pembangunan jati diri bangsa bukan hanya berkaitan dengan masalah intelektualitas tetapi juga berkaitan dengan masalah sosiao dan moral. Pembentukan moral dan etika sosial harus dilakukan sejak anak usia dini. Oleh karena itu, pendidikan jati diri bangsa bukan hanya perlu, tetapi harus diajarkan sejak SD. Pendidikan jati diri bangsa ini dimasukkan ke dalam mata pelajaran Kewarganegaraan atau Pancasila.

Bagi bangsa Indonesia, sesungguhnya sudah memiliki acuan bagi pembangunan jati diri bangsa, yakni Pancasila. Selain sebagai dasar negara dan pandangan hidup, Pancasila juga berfungsi sebagai jiwa dan kepribadian bangsa. Konsepsi ini membawa konsekwensi bahwa Pancasila harus menjadi pengarah dan pedoman sikap, tindakan dan ucapan dari setiap manusia Indonesia. Oleh karena itu, pendidikan Pancasila dan Kewarganegaraan menjadi sangat urgen dalam pembangunan jati diri bangsa.

Persoalannya, Pancasila itu masih bersifat abstrak, yang masih membutuhkan pemahaman dan penjabaran secara lebih operasional. Memang rumusan Pancasila sebagaimana yang tertuang dalam Pembukaan UUD 1945 yang oleh Notonagoro dikatakan masih abstrak, bahkan menurut Driyarkara masih bersifat tematis yang harus dijabarkan secara lebih operasional. Selain itu, selama ini Pancasila justru lebih diartikan sebagai ideologi yang sempit dan tertutup. Di sisi lain, pendidikan Pancasila di perguruan tinggi dan Kewarganegaraan (dulu PMP 
atau PPKn) pada pendidikan dasar dan menengah pada era Orde Baru dijadikan alat politik bagi mereka yang sedang berkuasa. Bahkan Pendidikan Pancasila dan Kewarganegaraan juga dijadikan sarana hegemoni bagi mereka yang berkuasa untuk membentuk kesadaran palsu. Pendidikan Pancasila bukan diterapkan dengan menggunakan pendekatan ilmiah, namun lebih banyak menggunakan pendekatan yang bersifat doktriner. Akibatnya, nilainilai Pancasila tidak tertanam, tetapi malah mendapat resistensi dari sebagian mahasiswa. Pendidikan Pancasila bukan menjadi kajian yang menarik bagi mahasiswa, tetapi malah dianggap sebagai beban. Demikian juga di tingkat pendidikan Dasar dan Menengah, pelajaran PPKn hanya dianggap oleh para siswa dan orang tua sebagai pelengkap dan beban yang tidak memberi manfaat begi mereka.

Kurangnya keberhasilan Pendidikan Pancasila dan Kewarganegaraan dalam membentuk moral dan kepribadian bangsa, selain pendekatan yang digunakan lebih bersifat doktriner, juga disebabkan oleh kurangnya pemahaman dan pengetahuan para pendidik. Selama ini mengajarkan Pendidikan Pancasila dan Kewarganegaraan di sekolah maupun diperguruan tinggi dipandang sebagai pekerjaan "mudah" yang bisa dilakukan oleh siapa saja. Paradigma seperti ini tentu kurang mendukung fungsi Pendidikan Pancasila sebagai pembentuk kepribadian bangsa. Untuk menjadi guru PPKn dibutuhkan beberapa syarat antara lain : memahami ilmu politik, sosiologi, hukum, filsafat, sejarah, dan harus memiliki moralitas yang bisa dijadikan suri tauladan. Sesuai dengan fungsinya sebagai dasar negara, pandangan hidup, dan ideologi, kajian dalam Pendidikan Pancasila dan Kewarganegaraan meliputi aspek yang sangat luas, yakni ideologi, politik, ekonomo, sosial, budaya dan pertahanan keamanan (Ipoleksosbudhankam), dengan menggunakan pendekatan kontekstual. Artinya Pendidikan Pancasila dan Kewarganegaraan tidak boleh dikurung dengan silabi yang normatif dan kaku, tetapi harus berkembang dan mengalir 
sesuai dengan permasalahan-permasalahan aktual yang diminati para siswa dan mahasiswa. Berbagai persoalan yang berkaitan dengan kehidupan berbangsa dan bernegara, seharusnya mampu dijelaskan oleh guru atau dosen Pendidikan Pancasila dan Kewarganegaraan dengan mendasarkan pada kajian-kajian yang ilmiah (berdasarkan fakta dan teori).

Kurangnya keteladanan dari para penyelenggara negara dalam ranah moral juga menjadi salah satu faktor yang menyebabkan Pendidikan Pancasila dan Kewarganegaraan kurang berhasil membentuk generasi muda menjadi pribadi-pribadi yang mulia. Pendidikan kepribadian yang di dalamnya termasuk moral, tidak cukup hanya dengan teori, tetapi juga membutuhkan keteladan. Artinya tidak hanya memberi contoh, tetapi menjadi contoh. Dalam kultur masyarakat Indonesia yang paternalistik, keteladanan dari para pemimpin sangat dibutuhkan dalam membentyuk kepribadian bangsa. Selama ini keteladanan dari para pemimpin sangat sulit dicari. Mereka justru memberi contoh yang kurang baik. Maraknya KKN di kalangan para eksekutif maupun legislatif dari pusat sampai daerah menjadi "counter" bagi Pendidikan Pancasila. Akibatnya Pendidikan Pancasila sering dilecehkan dengan pameo "ah itu kan teori", tetapi prakteknya justru jauh menyimpang dari apa yang diajarkan kepada para siswa maupun mahasiswa.

Upaya untuk membangun kepribadian bangsa memang bukan hanya tugas dari para lembaga pendidikan tinggi, melalui mata kuliah Pengembangan Kepribadian, tetapi menjadi tanggung jawab bersama dari seluruh komponen bangsa. Meskipun demikian, lembaga pendidikan khususnya perguruan tinggi mempunyai peran yang sangat strategis. Melalui kajian-kajian akademis, para dosen dapat memberikan pencerahan kepada mahasiswa, sehingga menjadi manusia-manusia kritis dan rasional. Dengan sikap yang kritis dan rasional dan didukung dengan 
pengetahuan dan pemahaman yang mendalam diharapkan mereka dapat memecahkan setiap persoalan secara bijak.

\section{PENUTUP}

Lunturnya nasionalisme, hilangnya jati diri bangsa memudahkan masuknya paham radikalisme dan terorisme. Hal ini disebabkan karena nilai-nilai ideologi Pancasila yang menganut konsep ideologi terbuka, implementasinya pada saat ini tidak berjalan dengan baik, padahal secara hakekatnya konsep ideologi yang digadang-gadang sangat fleksibel bagi semua pihak hanya menjadi impian karena tidak adanya implementasi yang nyata. Oleh karena itu perlu diantisipasi dengan merubah paradigma berpikir, mengkonstruksi diri serta membangun kembali jati diri bangsa dengan melaksanakan nilai-nilai Pancasila secara murni dan konsekuen dalam kehidupan yang nyata, mengingat pentingya nilai-nilai Pancasila sebagai filter dalam mengantisipasi arus globalisasi. Pancasila dengan jelas ditetapkan sebagai dasar negara, ideologi negara dan pandangan hidup bangsa. Pancasila yang merupakan sumber hukum dan tatanan kehidupan bangsa yang selalu ditanamkan pada seluruh rakyat Indonesia agar dapat dijalankan dan diimplementasikan dalam kehidupan yang nyata sesuai yang dicita-citakan.

\section{DAFTAR PUSTAKA}

Anderson, B., 2002, Imagined Communities. Terjemahan Omi Intan Naomi, Yogyakarta : INSIST

Ahimsa , Heddy., 2001, Pluralitas dan Tindak Kekerasan Massal :

Paradigma Sosial Budaya. Fakultas Sastra Universitas Airlangga

Featherstone, M., Lash S. And Robertson, R.(ed). 1995, Global Modernities. London : SAGE Publication. 
Gellner, Ernest, 1994, Ecounters With Nationalism. Cambridge : Blackweel.

Kaelan, 2000, Pendidikan Pancasila, Yogyakarta : Paradigma.

Lubis, Mochtar, 2001, Manusia Indonesia : Sebuah Pertanggungan Jawab : Jakarta, Yayasan Obor Indonesia.

Nasikun, 2004, Sistem Sosial Indonesia, Jakarta : Rajawali.

Notonagoro, 1975, Pancasila secara Ilmiah Populer, Jakarta : Pantjuran Tujuh.

Ohmae, K., 1995, The End of The Nation State The Rise of Regional Economics, New York : The Free Press.

Sartono, W., 2003, Pembangunan Bangsa, Tentang Nasionalisme, Kesadaran dan Kebudayaan Nasional, Yogyakarta : Aditya Media.

Warsono, 1999, Filsafat Pancasila, University Press IKIP Surabaya. 


\title{
KEDUDUKAN PANCASILA SEBAGAI SUMBER HUKUM DALAM PEMBENTUKAN PERATURAN PERUNDANG-UNDANGAN
}

\author{
A.A. Istri Eka Krisna Yanti \\ Fakultas Hukum Universitas Dwijendra \\ anakagungistriekakrisnayanti@gmail.com
}

\section{PENDAhUluan}

Pancasila merupakan pandangan hidup bangsa kenegaraan yang bersumber dari nilai-nilai agama, kebudayaan dan adat istiadat yang dirumuskan oleh para pendiri negara Indonesia. Secara konstitusional Pancasila ditetapkan menjadi dasar negara pada tanggal 18 Agustus 1945 dengan dimasukannya sila-sila Pancasila dalam pembukaan Undang-Undang Dasar Negara Republik Indonesia Tahun 1945 setelah melalui proses perundingan dengan dinamika yang panjang. Pancasila merupakan ideologi bangsa Indonesia yang menjadi dasar negara, pandangan hukum dan cita hukum (rechtidee) masyarakatnya dalam menjalani kehidupan berbangsa dan bernegara. Selain itu, Pancasila juga sarat dengan penghargaan terhadap nilai-nilai kemanusiaan dan perlindungan terhadap hak asasi manusia (Pujiono, 2007). Hal yang sama pernah diungkapkan oleh Satjipto Rahardjo di mana kedudukan Pancasila merupakan dasar dan sumber yang 
mengalirkan nilai, ide, tentang bagaimana masyarakat Indonesia hendaknya diorganisasikan (Rahardjo, 2009).

Kedudukan Pancasila sebagai sumber dari segala hukum juga mendapatkan legitimasi melalui TAP MPR No. XX/MPRS/1966 tentang Memorandum DPR-GR Mengenai Sumber Tertib Hukum Republik Indonesia dan Tata Urutan Peraturan Perundang Republik Indonesia, namun kemudian dicabut dan dinyatakan tidak berlaku karena menimbulkan kerancuan yang kemudian digantikan dengan TAP MPR No. III/MPR/2000 Tentang Sumber Hukum Dan Tata Urutan Peraturan PerundangUndangan. Dalam ketentuan Pasal 1 TAP MPR No. III/MPR/2000 Tentang Sumber Hukum Dan Tata Urutan Peraturan PerundangUndangan dengan tegas menyatakan bahwa Sumber hukum dasar nasional adalah Pancasila sebagaimana tertulis dalam Pembukaan Undang-Undang Dasar 1945, yaitu Ketuhanan Yang Maha Esa, Kemanusiaan yang adil dan beradab, Persatuan Indonesia dan Kerakyatan yang dipimpin oleh hikmah kebijaksanaan dalam permusyawaratan/perwakilan, serta dengan mewujudkan suatu Keadilan sosial bagi seluruh rakyat Indonesia dan batang tubuh Undang-Undang Dasar 1945. Pancasila sebagai sumber hukum nasional dijadikan bahan untuk penyusunan peraturan perundangundangan.

Pengaturan TAP MPR memperjelas maksud dari istilah sumber hukum dalam sistem hukum di Indonesia adalah tempat untuk menemukan dan menggali hukum, selain itu Pancasila dijadikan sebagai rujukan utama dalam pembentukan berbagai peraturan perundang-udanganan yang ada di Indonesia. Saat ini, keradaan Pancasila sebagai sumber dari segala hukum dikukuhkan melalui Undang-Undang Nomor 10 Tahun 2004 yang kemudian diganti dengan Undang-Undang Nomor 12 Tahun 2011 tentang Peraturan Perundang-Undangan. Berdasarkan Pasal 2 UndangUndang No.12 Tahun 2011 Tentang Pembentukan Peraturan 
Perundang-Undangan disebutkan bahwa Pancasila merupakan sumber segala sumber hukum negara sesuai dengan Pembukaan UUD NRI Tahun 1945.

Menurut Roeslan Saleh, fungsi Pancasila sebagai sumber segala sumber hukum memiliki arti sebagai berikut;

1. Ideologi hukum Indonesia;

2. Kumpulan nilai-nilai yang harus berada di belakang keseluruhan hukum Indonesia;

3. Asas-asas yang harus diikuti sebagai petunjuk dalam mengadakan pilihan hukum di Indonesia;

4. Sebagai suatu pernyataan dari nilai kejiwaan dan keinginan bangsa Indonesia, juga dalam hukumnya (Saleh, 1979).

Kedudukan Pancasila sebagai sumber dari segala sumber hukum juga menempatkan Pancasila sebagai dasar dan ideologi negara sekaligus sebagai dasar filosofi negara sehingga setiap materi muatan peraturan perundangan-undangan tidak boleh bertentangan dengan nilai nilai yang terkandung didalam Pancasila (BPHN, 2019). Namun, berdasarkan Evaluasi Badan Pembinaan Hukum Nasional (BPHN), pada tahun 2019 diketahui bahwa terdapat 63 dari 84 sehingga perlu direvisi karena bertentangan dengan nilai-nilai Pancasila sebagai sumber hukum. Disisi lain, sejak tahun 2003 sampai dengan Januari 2020 terdapat 264 permohonan pengujian konsititusi yang dikambulkan oleh Mahkamah, hal ini menunjukan terdapat 264 peraturan perundangundangan yang bertentangan dengan ketentuan Konstitusi (Purwanti, 2020), dan lebih jauh dapat pula dikatakan, nilai-nilai Pancasila. Hal ini sungguh ironi, mengingat Pancasila merupakan sumber dari segala sumber hukum namun dalam pembentukan peraturan perundang-undagan nilai-nilai Pancasila belum tertuang secara baik dalam pembentukan peraturan perundang-undangan. 


\section{PEMBAHASAN}

\subsection{Aktualisasi Pancasila Dalam Pembentukan Peraturan Perundang-Undangan}

Berdasarkan ketentuan Pasal 1 ayat (3) UUD NRI disebutkan bahwa Indonesia adalah negara Hukum, sehingga setiap hal di Indonesia diatur dengan hukum guna menciptakan keamanan dam ketertiban dimasyarakat. Bentuk hukum yang dimaksud adalah peraturan perundang-undangan. Dalam Pasal 1 angka 2 UndangUndang No.12 Tahun 2011 Tentang Pembentukan Peraturan Perundang-Undangan ditentukan bahwa Peraturan Perundangundangan adalah peraturan tertulis yang memuat norma hukum yang mengikat secara umum dan dibentuk atau ditetapkan oleh lembaga negara atau pejabat yang berwenang melalui prosedur yang ditetapkan dalam peraturan perundang-undangan. Pengertian ini menunjukkan unsur-unsur agar dapat dikatakan sebagai peraturan perundang-undangan, diantaranya:

a. Peraturan tertulis yang memuat norma hukum yang mengikat secara umum;

b. Dibentuk atau ditetapkan oleh lembaga negara atau pejabat yang berwenang;

c. Pembentukan dan penetapannya melalui prosedur yang ditetapkan dalam peraturan perundang-undangan.

Dalam ketentuan asas pembentukan peraturan perundangundangan juga disebutkan dengan jelas bahwa dalam pembentukan perundang-undangan harus terdapat kesesuaian hierarki. Adapaun susunan hierarki yang telah ditetapkan dalam Pasal 7 ayat (1) UU PPPU yaitu:

a. Undang-Undang Dasar Negara Republik Indonesia Tahun 1945 ;

b. Ketetapan Majelis Permusyawaratan Rakyat; 
c. Undang-Undang/Peraturan Pemerintah Pengganti UndangUndang;

d. Peraturan Pemerintah;

e. Peraturan Presiden;

f. Peraturan Daerah Provinsi; dan

g. Peraturan Daerah Kabupaten/Kota.

Kerangka teoritik tentang hierarki peraturan perundangundangan pada UU PPPU sejalan dengan Stufenbau Theorie yang diceutusakan oleh Hans Kelsen, dengan uraian sebagai berikut:

a. Hukum mengatur kriterianya sendiri sepanjang suatu norma menentukan cara norma lain dibuat, dan juga isi norma tersebut. Sejak suatu norma hukum adalah valid karena dibuat dengan cara yang ditentukan oleh norma hukum lain, maka norma terakahir merupakan alasan validitas pertama.

b. Norma yang menentukan pembuatan norma yang lain adalah norma yang lebih tinggi, sedangkan norma yang dibuat ini adalah norma yang lebih rendah.

c. Tata hukum bukanlah sistem norma yang satu sama lain hanya dikoordinasikan, yang berdiri sejajar atau sederajat, melainkan suatu hierarki norma-norma dari tingkatan yang berbeda.

d. Kesatuan norma-norma ini disusun oleh fakta bahwa pembentukan norma yang lebih rendah ditentukan oleh norma yang lebih tinggi, yang pembentukannya ditentukan oleh norma yang lebih tinggi lagi, dan diakhiri oleh norma yang lebih tinggi yang merupakan norma dasar, yang menjadi alasan utama validitas dari keseluruhan tata hukum yang membentuk kesatuan.

Stufenbau Theorie atau yang dikenal dengan teori penjenjangan norma dikemukakan oleh Hans Kelsen yang 
mengemukakan bahwa hukum digambarkan sebagai hierarki norma-norma. Menurut Hans Kelsen tentang hirarkhi mengatakan bahwa norma-norma itu berjenjang-jenjang dan berlapis-lapis dalam suatu hierarki tata susunan, dimana norma yang lebih rendah berlaku, bersumber dan berdasarkan pada norma yang lebih tinggi, demikian seterusnya sampai sampai pada suatu norma yang tidak dapat ditelusuri lebih lanjut, dan bersifat hipotesis, serta fiktif yaitu norma dasar (groundnorm/ basic norm/ fundamental norm.)

Dalam perjalannya, Stufenbau Theorie yang dicetuskan oleh Hans Kelsen dikembangkan oleh oleh muridnya Hans Nawiasky dengan teori Jenjang Norma Hukum (Dei Theorie Von Stufenordnung der rechtsnormen) yang dibagi dalam 4 tingkatan yaitu;

a. Staatsfundamentalnorm yang berupa norma dasar bernegara atau sumber dari segala sumber hukum;

b. Staatsgrundgezetzeyang berupa hukum dasar yang apabila dituangkan dalam dokumen negara menjadi konstitusi atau vervassung;

c. Formelegezetzeatau undang-undang formal yang pada peraturan tersebut dapat ditetapkan suatu ketentuan yang bersifat imperative, dalam pengertian pelaksanaan maupun sanksi hukum;

d. Verordnung endan autonome satzungenyakni aturan-aturan pelaksanaan dan peraturan yang otonom, baik yang lahir dari delegasi maupun atribusi (Kurnisar, 2020)

Merujuk pada hierarki hukum yang dicetuskan oleh Hans Nawiasky maka Pancasila berada pada tataran staatsfundamentalnorm. Hans Nawiasky menegaskan, Staatfundamentalnorm atau norma fundamental negara (norma dasar) adalah norma tertinggi dalam suatu negara dan norma ini merupakan norma yang tidak dibentuk oleh norma yang lebih tinggi lagi, tetapi bersifat pre-supposed atau ditetapkan terlebih dahulu oleh masyarakat dalam negara dan merupakan norma yang 
menjadi tempat bergantungnya norma-norma hukum di bawahnya. Bahkan Nawiasky juga menegaskan bahwa isi norma fundamental negara merupakan dasar bagi pembentukan konstitusi atau undangundang dasar (Indrati, 2007). Sementara Itu, Jimly Asshiddiqie menyebutkan bahwa tidak semua nilai-nilai yang terdapat dalam konstitusi merupakan staatfundamentalnorm. Menurut Jimly Assihiddiqie, Nilai-nilai yang termasuk staatsfundamentalnorm menurutnya hanya spirit nilai-nilai yang terkandung di dalam konstitusi itu, sedangkan norma-norma yang tertulis di dalam pasal-pasal undang-undang dasar termasuk kategori abstract norms. Oleh karena itu, jika dikaitkan dengan sistem konstitusi Republik Indonesia, dapat dibedakan antara Pembukaan UUD 1945, dengan pasal-pasal UUD Negara Republik Indonesia Tahun 1945 (Asshiddiqie, 2006).

Akan tetapi, walaupun Pancasila sebagai sumber dari segala sumber hukum yang memiliki legitimasi yudiris pada UUD NRI Tahun 1945 serta TAP MPR tetap saja tidak memberikan jaminan kepastian hukum dalam tata urutan peraturan perundangundangan. Akibatnya Pancasila sebagai sumber dari segala sumber hukum tidak memiliki unsur imperatif atau daya ikat dalam hirarki peraturan perundang-undangan (Thontowi, 2016). Kondisi hieraki peraturan perundang-undangan yang ada saat ini menjadi pemicu munculnya disharomisasi antara Peraturan Perundang Undangan.

Pancasila merupakan sumber hukum meteril yang ditentukan oleh muatan atau bobot materi yang terkandung dalam Pancasila. Terdapat tiga kualitas materi Pancasila yaitu: pertama, muatan Pancasila merupakan muatan filosofis bangsa Indonesia. Kedua, muatan Pancasila sebagai identitas hukum nasional. Ketiga, Pancasila tidak menentukan perintah, larangan dan sanksi melainkan hanya menentukan asas-asas fundamental bagi pembentukan hukum (meta-juris) (Pinasang, 2012). 


\subsection{Menerapkan Pancasila Sebagai Sumber Hukum Dalam Pembentukan Peraturan Perundang-Undangan}

Secara yuridis kedudukan Pancasila sebagai sumber dari segala sumber hukum disebutkan dalam TAP MPR dan UPPU namun hal tersebut tidak menjamin penerapan Pancasila dalam pembentukan peraturan perundang-undangan. Faktanya telah terdapat begitu banyak peraturan perundang-undangan yang telah menyimpang dari Pancasila., sebagaimana Hasil Kajian Badan Pembinaan Ideologi Pancasila pada tahun 2019 menyimpukan terdapat 63 dari 84 Undang-Undang yang perlu direvisi karena bertentangan dengan nilai-nilai Pancasila (Purwanti, 2020).

Penyimpangan nilai-nilai Pancasila berpotensi akan terulang kembali, jika Pancasila tidak termasuk dalam hirarki peraturan perundang-undangan.. Fais Yonas Bo'a dalam jurnalnya berpendapat perlunya mendudukan Pancasila sebagai puncak hirarki pertauran perundang-undangan meskipun Pancasila telah memiliki legitimasi yuridis pada UUD NRI Tahun 1945 dan TAP MPR. Apabila merujuk pada stufenbautheory Kelsen dan Nawiasky yang mengharuskan puncak hirarkis norma adalah norma dasar atau Grundnorm/Staatfundamentalnorm maka Pancasila sebagai norma dasar seharusnya berada dalam puncak tata urutan norma tersebut. Dengan demikian, tata urutan peraturan perundangundangan dari atas ke bawah menjadi sebagai berikut:

a. Pancasila,

b. Undang-Undang Dasar Negara Republik Indonesia Tahun 1945 ,

c. Ketetapan Majelis Permusyawaratan Rakyat Republik Indonesia,

d. Undang-Undang/Peraturan Pemerintah Pengganti UndangUndang

e. Peraturan Pemerintah,

f. Peraturan Presiden, 
g. Peraturan Daerah Provinsi; dan

h. Peraturan Daerah Kabupaten/Kota (Bo’a, 2018).

Mendudukan Pancasila sebagai puncak hirarki peraturan PPU bukan bermaksud mengurai keberaan Pancasila sebagai pandangan hidup dan dasar negara melainkan sebagai upaya untuk menghindari penyimpangan-penyimpangan peraturan perundangundangan. Boa berpendapat dimasukannya Pancasila dalam hirerki PPU agar memiliki daya mengikat bagi segala peraturan perundang-undangan untuk meminimalisir terjadinya konflik norma/disharmonisasi antara peraturan perundang-undagan. Disharmonisasi antara antara peraturan perundang-udangan tersebut memiliki dua makna yaitu: pertama, UU tersebut tidak mampu menjadi konkritisasi UUD 1945 dan mengingkari Pancasila sebagaimana termaktub dalam Pembukaan UUD 1945. Kedua, UUD 1945 yang termasuk dalam hirarki peraturan perundangundangan saja masih memberi ruang untuk dilanggar apalagi Pancasila yang tidak termasuk dalam tata urutan peraturan perundang-undangan (Bo'a, 2018). Dengan demikian, merujuk pada aliran positivism hukum yang mengedepankan kepastian hukum maka Pancasila harus dimasukan dalam hierarki peraturan perundang-undagan.

Merujuk pada Undang-Undang Nomor 12 Tahun 2011 Tentang Pembentukan Peraturan Perundang-Undangan yang kini telah diubah beberapa ketentuannya dengan Undang-Undang Nomor 15 Tahun 2019 terdapat pedoman mengakualisasikan nilainlail Pancasila.Pancasila merupakan sumber dari segala sumber hukum negara. Hal ini diatur pada Pasal 2 Undang-Undang Nomor 12 Tahun 2011. Penjelasan Pasal 2 menegaskan, "Penempatan Pancasila sebagai sumber dari segala sumber hukum negara adalah sesuai dengan pembukaan Undang-Undang Dasar Negara Republik Indonesia Tahun 1945 alinea keempat yaitu Ketuhanan Yang Maha Esa, Kemanusiaan yang adil dan beradab, Persatuan Indonesia, 
Kerakyatan yang dipimpin oleh hikmat kebijaksanaan dalam Permusyawaratan/Perwakilan dan Keadilan Sosial bagi seluruh rakyat Indonesia. Menempatkan Pancasila sebagai dasar dan ideologi negara serta sekaligus filosofis negara sehingga setiap materi muatan peraturan perundang-undangan tidak boleh bertentangan dengan nilai-nilai yang terkandung dalam Pancasila”.

Jika ditelaah ketentuan pada Pasal 2 Undang-Undang Nomor 12 Tahun 2011 Tentang Pembentukan Peraturan Perundang - Undangan hanya terhenti sampai disitu, tidak ada penjabaran ataupun uraian lebih lanjut atas kedudukan Pancasila dalam pembentukan peraturan perundang-undangan, tidak dijelaskan sejauh mana Pancasila harus masuk kedalam pembentukan peraturan perudangan-undangan. Dalam Pembentukan peraturan perundang-undangan mecakup tahapan perencanaan, penyusunan, pembahasan, pengesahan atau penetapan dan pengundangan dengan ruang Pancasila yang masih sangat terbatas. Namun dalam penyusunan Naskah Akdemik dapat ditemukan ruang bagi Pancasila.

Berdasarkan ketentuan Pasal 1 ayat (11) Naskah Akademik didefinisikan sebagai naskah hasil penelitian atau pengkajian hukum dan hasil penelitian lainnya terhadap suatu masalah tertentu yang dapat dipertanggungjawabkan secara ilmiah mengenai pengaturan masalah tersebut dalam suatu Rancangan Undang-Undang, Rancangan Peraturan Daerah Provinsi, atau Rancangan Peraturan Daerah Kabupaten/Kota sebagai solusi terhadap permasalahan dan kebutuhan hukum masyarakat. Dari definisi tersebut dapat dipahami bahwa Naskah Akademik bukanlah dokumen wajib dalam suatu pembentukan peraturan perundang-undangan hanya mencakup Rancangan Undang-Undang, Rancangan Peraturan Daerah Provinsi, atau Rancangan Peraturan Daerah Kabupaten/Kota, tidak mencakup jenis peraturan perundang-undangan lainnya yang terdapat dalam hierarki PPU. Disisi lain, ketentuan perundang-undangan juga 
memberikan pengecualian bagi Rancangan Undang-Undang, Rancangan Peraturan Daerah Provinsi, atau Rancangan Peraturan Daerah Kabupaten/Kota untuk tidak mencantumkan Naskah Akademik salah satunya apabila mengenai Anggaran Pendapatan dan Belanja.

Dalam penyusunan Naskah Akademik, sebagaimana Lampiran 1 Undang-Undang No. 12 Tahun 2011 Tentang Pembentukan Peraturan Perundang Indangan telah ditentukan sistematika penyusunan Naskah Akademik. Pada bagian Landasan Filosofis memuat pertimbangan ataupun alasan yang menggambarkan pandangan hidup. Kesadaran dan cita hukum yang meliputi suasana kebatian serta falsafah bangsa Indonesia yang bersumber dari Pancasila dan Pembukaan Undang-Undang Dasar Negara Republik Indonesia Tahun 1945. Landasan filosofis dalam pembentukan Naskah Akademik menegaskan, pandangan hidup, kesadaran, dan cita hukum yang menjadi pertimbangan dalam membentuk suatu undang-undang, haruslah bersumber dari Pancasila. Namun hanya bersifat umum dan belum ada indikator dan variable tentang nilai-nilai Pancasila yang menjadi tolak ukur dalam penyusunannya. Berkenaan dengan hal ini, dalam berbagai Naskah Akademik Undang-undang, apabila diamati, yang terlihat hanya pencantuman sila tertentu saja dari Pancasila saja, bukan nilai-nilai yang terkandung di dalamnya. Naskah Akademik juga masih dominan menggunakan tolok ukur pasal-pasal dalam Konstitusi UUDNRI 1945. Padahal, dalam Undang-Undang Nomor 12 Tahun 2011 Tentang Pembentukan Peraturan PerundangUndangan disebutkan, Pancasila merupakan merupakan sumber dari segala sumber hukum (Nasution dan Febrian, 2020).

Setelah dilakukan penyusunan, dilakukan proses pengharmonisasian, Pembulatan, dan Pemantapan Konsepsi Rancangan Undang-Undang dalam Kegiatan Penyelarasan Rancangan Undang-Undang yang diatur dalam Pasal 51 ayat (4) Peraturan Presiden Republik Indonesia Nomor 87 Tahun 2014 
Tentang Peraturan Pelaksanaan Undang-Undang Nomor 12 Tahun 2011 Tentang Pembentukan Peraturan Perundang-Undangan. Proses Pengharmonisasian, pembulatan, dan pemantapan konsepsi Rancangan Undang-Undang, dimaksudkan untuk menyelaraskan Rancangan Undang-Undang dengan cara;

a. Pancasila, Undang-Undang Dasar Negara Republik Indonesia Tahun 1945, dan Undang-Undang lain; dan

b. Teknik penyusunan peraturan perundang-undangan.

Selain itu juga dengan menghasilkan kesepakatan terhadap PEMBAHASAN yang diatur dalam Rancangan Undang-Undang. Ketentuan mengenai pengharmonisasian, pembulatan, dan pemantapan konsepsi rancangan undang-undang juga diatur dalam Peraturan Menteri Hukum dan HAM Nomor 20 Tahun 2015 Tentang Tata Cara Dan Prosedur Pengharmonisasian, Pembulatan, Dan Pemantapan Konsepsi Rancangan Peraturan Perundang-Undangan. Rumusan tentang Pancasila terdapat dalam Pasal 3 huruf a, angka 1, bahwa "Pengharmonisasian Konsepsi Rancangan Peraturan Perundang-undangan dilakukan dengan tujuan untuk: a. menyelaraskan dengan: 1. Pancasila, Undang-Undang Dasar Negara Republik Indonesia Tahun 1945, dan peraturan perundang-undangan lain”. Rumusan lainnya juga diatur dalam Pasal 10 ayat (3) huruf a, "Analisis konsepsi Rancangan Peraturan Perundang-undangan terhadap PEMBAHASAN sebagaimana dimaksud pada ayat (2), dilakukan dengan memperhatikan: a. keterkaitan dan keselarasan PEMBAHASAN dengan Pancasila, Undang-Undang Dasar Negara Republik Indonesia Tahun 1945, dan peraturan perundang-undangan lain".

Rumusan pengharmonisasian, pembulatan, dan pemantapan konsepsi rancang-an undang-undang dalam Peraturan Presiden Republik Indonesia Nomor 87 Tahun 2014 Tentang Peraturan Pelaksanaan Undang-Undang Nomor 12 Tahun 2011 Tentang Pembentukan Peraturan Perundang-Undangan. Proses 
Pengharmonisasian, pembulatan, dan pemantapan konsepsi Rancangan Undang-Undang, dan Peraturan Menteri Hukum dan HAM Nomor 20 Tahun 2015 Tentang Tata Cara Dan Prosedur Pengharmonisasian,Pembulatan, Dan Pemantapan Konsepsi Rancangan Peraturan Perundang-Undangan kembali tidak menentukan indokator dan variable nilai nilai pancasila yang dimaksudkan. Sisi lain, Pancasila dan UUD NRI 1945 dijadikan ukuran yang bersamaan dalam proses pengharmonisan, pembulatan dan pemantapan konsepsi RUU, yang secara tidak langsung berarti menafsirkan Pancasila dan UUDNRI 1945 sebagai dua hal berbeda meskipun sila-sila Pancasila terdapat dalam alenei ke-4 UUD NRI. Indikator Pancasila merupakan nilai-nilai yang tertuang dalam Pancasila sedangkan Indikator UUD NRI merupakan adalah pasalpasal yang terdapat dalam UUD NRI.

Kurnisar menyebutkan UUD Negara Republik Indonesia Tahun 1945 tidak tepat dikatakan sebagai peraturan perundangundangan disebabkan oleh alasan bahwa UUD Negara Republik Indonesia Tahun 1945 terdiri atas dua kelompok norma hukum yaitu:

a. Pembukaan UUD Negara Republik Indonesia Tahun 1945 yang merupakan staatsfundamentalnormatau norma fundamental negara yang merupakan norma hukum yang tertinggi bersifat"pre-sup-posed" dan merupakan landasan dasar bagi pengaturan negara lebih lanjut. Sifat norma hukumnya masih secara garis besar dan merupakan norma hukum tunggal, dalam arti belum dilekati oleh norma hukum yang berisi sanksi;

b. Pasal-pasal UUD Negara Republik Indonesia Tahun 1945 merupakan staatsgrundgesetzatau aturan dasar negara/aturan pokok negara yang merupakan garis-garis besar atau pokokpokok kebijaksanaan negara untuk menggariskan tata cara 
pembentukan peraturan perundang-undangan yang mengikat umum (Kurnisar, 2020).

Dalam peraturan perundang-undagan materi muatan materi muatan merupakan pokok dari isi peraturan perundangundangan. Pasal 6 Undang-Undang Nomor 12 Tahun 2011 mengatur, mengenai asas materi muatan peraturan perundangundangan menegaskan, terdapat 10 poin, yakni pengayoman; kemanusiaan; kekeluargaan; kenusantaraan; bhineka tunggal ika; keadilan; kesamaan kedudukan dalam hukum dan pemerintahan; ketertiban dan kepastian hukum dan/atau keseimbangan; keserasian; dan keselarasan. Merujuk pada ketentuan Pasal 29 ayat (1) UUD 1945 disebutkan bahwa Negara berdasarkan atas Ketuhanan Yang Maha Esa sesuai dengan sila pertama Pancasila, untuk Itu BPHN dalam hasil evalusianya menyatakan bahwa perlu ditambahkannya asas "Ketuhanan Yang Maha Esa pada pasal 6 ayat (1) UU PPU sebagai konsekuensi yuridis pasal 29 ayat (1) UUD NRI.

\section{PENUTUP}

Berdasarkan uraian, mendudukan Pancasila sebagai hierarki PPU untuk secara tegas menjabarkan rumusan indikator dan nilai-nilai Pancasila yang dapat dijadikan pedoman dalam pembentukan undang-undang. Terlebih mengingat ketentuan Pasal 2 Undang-Undang No.12 Tahun 2012 yang menentukan bahwa Pancasila merupakan sumber segala sumber hukum negara. sesuai dengan Pembukaan Undang-Undang Dasar Negara Republik Indonesia Tahun 1945 alinea keempat yaitu Ketuhanan Yang Maha Esa, Kemanusiaan yang adil dan beradab, Persatuan Indonesia, Kerakyatan yang dipimpin oleh hikmat kebijaksanaan dalam Permusyawaratan/Perwakilan, dan Keadilan sosial bagi seluruh rakyat Indonesia. Pancasila memiliki kedudukan yang sangat 
penting dalam dalam Pembentukan Peraturan PerundangUndangan. Saat ini kedudukan Pancasila sebagai sumber dari segala sumber hukum negara dan telah dijabarkan dalam Pembukaan UUD NNRI Tahun 1945 dan TAP MPR RI. Namun hingga saat ini belum terdapat cukup ruang untuk mengatualisasikan kedudukan Pancasila sebagai sumber dari segala sumber hukum negara karena belum adanya indikator dalam pengimplentasian nilai-nilai Pancasila dalam pembentukan peraturan perundang-undangan meskipun dalam Naskah Akdemik memuat landasan filosifis sebagai ruang aktualisasi Pancasila namun ruangnya sangat terbatas. Merujuk pada teori staatsfundamentalnorm Hans Nawiasky maka Pancasila dapat dipisahkan kedudukannya dalam hirerarki peraturan perundangundagan untuk mecengah terjadinya disharmonisasi norma

\section{DAFTAR PUSTAKA}

Assihiddiqie, Jimly. 200, Pengantar Ilmu Tata Negara, Sekretariat Jenderal dan Kesekretariatan Mahkamah Konstitusi RI, Jakarta.

Ani Purwanti 2020, Advokasi dan Pengawasan Regulasi Badan Pembinaan Ideologi Pancasila, Rekomendasi Kebijakan dan Regulasi Berlandaskan Pancasila, Paparan pada Seminar dan Presentasi Kajian, Analisis dan Rekomendasi Perundangundangan Tahun 2020,

Badan Pembinaan Hukum Nasional Republik Indonesia, 2019 "Laporan Akhir Kelompok Kerja Analisis dan Evaluasi Hukum terkait Penguatan Ideologi Pancasila Tahun 2019", Kementrian Hukum dan HAM RI 2019

Jawahir Thontowi, 2016, Pancasila Dalam Perspektif Hukum;Pandangan Terhadap Ancaman The Lost Generation, Yogyakarta: UII Press

Rahardjo,2009, Pendidikan Hukum Sebagai Pendidikan Manusia,Yogyakarta:Genta Publishing 
Roeslan Saleh, 1979, Penjabaran Pancasila dan UUD 1945, Jakarta: Aksara Baru, 1979

Maria Farida Indrati S., Ilmu Perundang-Undangan I (Jenis, Fungsi dan Materi Muatan), Yogyakarta: Penerbit PT Kanisius, 2007,.

Nasution, B. J., \& Febrian, F. (2020). Aktualisasi Pancasila sebagai

Sumber Hukum dalam Pembentukan Undang-Undang.

Undang: Jurnal Hukum, 3(2), 377-407.

Pujiono, 2007, Kumpulan Tulisan Hukum Pidana, Bandung: Mandar Maju,

\section{Jurnal}

Bo'a, F. Y. (2018). Pancasila sebagai sumber hukum dalam sistem hukum nasional. Jurnal Konstitusi, 15(1), 21-49.

Kurnisar, K. (2020). PANCASILA SUMBER DARI SEGALA SUMBER HUKUM DI INDONESIA. Media Komunikasi FPIPS, 10(2).

Pinasang, D. (2012). Falsafah Pancasila Sebagai Norma Dasar (Grundnorm) Dalam Rangka Pengembanan Sistem Hukum Nasional. Jurnal Hukum UNSRAT, 20(3), 1-10.

\section{Peraturan Perundang-Undangan}

Undang-Undang Dasar Negara Republik Indonesia Tahun 1945

TAP MPR No. XX/MPRS/1966 tentang Memorandum DPR-GR

Mengenai Sumber Tertib Hukum Republik Indonesia dan

Tata Urutan Peraturan Perundang Republik Indonesia

TAP MPR No. III/MPR/2000 Tentang Sumber Hukum Dan Tata Urutan Peraturan Perundang-Undangan

Undang-Undang Nomor 10 Tahun 2004 tentang Pembentukan Peraturan Perundang-Undangan

Undang-Undang Nomor 12 Tahun 2011 tentang Pembentukan Peraturan Perundang-Undangan. 
Undang-Undang Nomor 15 Tahun 2018 Tentang Perubahan atas Undang-Undang Nomor 12 Tahun 2011 Tentang Pembentukan Peraturan Perundang-Undangan

Peraturan Presiden Republik Indonesia Nomor 87 Tahun 2014 Tentang Peraturan Pelaksanaan Undang-Undang Nomor 12 Tahun 2011 Tentang Pembentukan Peraturan PerundangUndangan. Proses Pengharmonisasian, pembulatan, dan pemantapan konsepsi Rancangan Undang-Undang,

Peraturan Menteri Hukum dan HAM Nomor 20 Tahun 2015 Tentang Tata Cara Dan Prosedur Pengharmonisasian,Pembulatan, Dan Pemantapan Konsepsi Rancangan Peraturan Perundang-Undangan 


\section{AKSIOLOGI PANCASILA DAN TANTANGANNYA DI TENGAH DISRUPSI PEMBELAJARAN}

\section{Dewa Made Dwicky Putra Nugraha}

Fakultas Keguruan dan Ilmu Pendidikan Universitas Dwijendra madedwicky@undwi.ac.id

\section{PENDAHULUAN}

Pancasila merupakan dasar ideologi bangsa Indonesia. Sebagai sebuah ideologi, Pancasila menjadi inspirasi dari segala tindak-tanduk bangsa. Pancasila menduduki kasta tertinggi dalam hal pedoman kehidupan berbangsa dan bernegara di Indonesia. Kesadaran terhadap Pancasila perlu ditanamkan sejak dini pada setiap insan bangsa Indonesia. Baik secara formal, in-formal, bahkan non-formal. Nilai-nilai Pancasila harus melebur dalam setiap norma dan tata perilaku yang tumbuh di masyarakat.

Kesadaran terhadap nilai-nilai Pancasila perlu ditumbuhan dalam pergaulan sehari-hari. Sebab, nilai Pancasila telah lama disepakati sebagai pedoman dalam memelihara kemaslahatan dan kehidupan bernegara. Pemahaman ini sesuai dengan pandangan filsafat terhadap Pancasila itu sendiri. Filsafat tentang Pancasila dapat ditinjau secara epistimologi, ontologi, dan aksiologi. Apabila konteks Pancasila diarahkan kepada nilai manfaat, maka perlu dijawab melalui kajian aksiologis. Menurut Kattsoff (2004), 
aksiologi dapat diartikan sebagai sudut pandang keilmuan yang menyelidiki hakikat nilai. Kajian aksiologi memberi arah pada manusia untuk melakukan sesuatu yang baik dan mengekspresikan keindahan yang diharapkan. Pemahaman terkait aksiologi Pancasila menjadi semakin penting di tengah era disrupsi pembelajaran.

Arti kata disrupsi dalam KBBI adalah hal yang dicabut dari akarnya. Menurut Fukuyama (dalam Ohoitimur, 2018) memandang disrupsi sebagai gangguan atau kekacauan yang terjadi di masyarakat. Dalam pembahasan ini, disrupsi diterjemahkan sebagai fenomena pergeseran nilai atau prinsip fundamental akan suatu hal dari kebiasaan sebelumnya. Disrupsi dapat menjamah berbagai rutinitas kehidupan masyarakat, termasuk pembelajaran. Disrupsi pembelajaran muncul seiring terjadinya disrupsi tekonologi. Sebagaimana diketahui, pesatnya perkembangan ilmu pengetahuan dan teknologi telah mengubah berbagai hal. Mulai dari perilaku hidup, hingga ke tatanan masyarakat yang lebih kompleks seperti pola interaksi dan pergeseran cara pandang.

Dunia pendidikan juga tak luput dari dampak disrupsi teknologi. Produk teknologi seperti gadget dan laptop, membuat batas-batas antar manusia dan antar negara menjadi samar. Segala hal bisa diketahui dan dilakukan hanya dengan bermodal jari jemari dan akses internet. Hal ini juga terjadi pada situasi pembelajaran di seluruh dunia. Saat ini, pembelajaran tidak lagi terbatas pada ruang dan waktu. Peserta didik dapat belajar dengan siapapun, apapun, dan dimanapun melalui bantuan teknologi. Inilah yang mendasari pandangan tentang telah terjadinya disrupsi pembelajaran.

Disrupsi pembelajaran layaknya dua mata pisau. fenomena ini adalah kabar gembira sekaligus kabar yang mengkhawatirkan. Di satu sisi, disrupsi pembelajara merupakan fakta positif yang tidak dapat kita tolak. Sebab, untuk memenangkan persaingan global, salah satu kuncinya memang menguasai ilmu pengetahuan dan teknologi. Generasi yang melek teknologi adalah mereka yang 
akan memenangkan masa depan. Namun, tanpa pagar yang kokoh, kemajuan ini justru berpotensi menghancurkan. Paham-paham negatif dan informasi provokatif sangat sulit dikontrol persebarannya di dunia maya.

Peserta didik yang memiliki akses terbuka terhadap gadget dan internet sangat riskan menerima pengaruh yang negatif. Dengan meningkatnya frekuensi belajar melalui dunia maya, potensi peserta didik mengakses hal-hal diluar pembelajaran juga akan makin tinggi. Hal ini tentu menjadi tantangan bagi pendidikan itu sendiri. Bagaimanapun, pendidikan adalah upaya terukur yang diselenggarakan dalam rangka menyiapkan generasi bangsa yang cerdas dan berkarakter. Desiminasi terhadap urgensi ini perlu berangkat dari kajian tentang Pancasila secara aksiologis. Sebagai sebuah nilai yang diikuti, Pancasila diharapkan mampu menjawab berabagi tantangan baru di tengah disrupsi pembelajaran.

\section{PEMBAHASAN}

\subsection{Kajian Aksiologi Pancasila}

Aksiologi merupakan cabang filsafat ilmu yang mempertanyakan bagaimana manusia menggunakan ilmunya. Aksiologi adalah istilah yang berasal dari kata Yunani yaitu axios yang berarti nilai/manfaat. Sedangkan logos yang berarti pikiran, ilmu atau teori. Aksiologi diartikan sebagai teori nilai yaitu sesuatu yang diinginkan, disukai atau yang baik. Aksiologi membahas tentang nilai secara teoretis yang mendasar dan filsafati, yaitu membahas nilai sampai pada hakikatnya (Kattsoff, 2004). Karena aksiologi membahas tentang nilai secara filsafati, maka juga disebut philosophy of value (filsafat nilai). Jadi Aksiologi merupakan ilmu yang mempelajari hakikat dan nilai manfaat yang sebenarnya dari pengetahuan akan sesuatu. 
Hakikat nilai adalah kualitas yang melekat dan menjadi ciri segala sesuatu yang ada di alam semesta dihubungkan dengan kehidupan manusia. Nilai bukanlah murni pandangan pribadi terbatas pada lingkungan manusia. Pengertian nilai apabila dibahas secara filsafati adalah persoalan tentang hubungan antara manusia sebagai subjek dengan kemampuan akalnya untuk menangkap pengetahuan tentang kualitas objek-objek di sekitarnya. Nilai dapat diartikan sebagai kesadaran manusia menangkap sesuatu yang berharga di alam semesta (Brennan, 1996).

Kajian aksiologi menerangkan bahwa Pancasila digunakan sumber nilai bagi kehidupan bangsa Indonesia. Dengan kata lain, Pancasila dijadikan sebagai pedoman utama dalam berlaku, beretika, dan mengimplementasikan segala norma dalam tatanan kehidupan bernegara. Di dalamnya terkandung pemikiranpemikiran yang bersifat kritis, mendasar, rasional, sistematis dan komprehensif, sehingga sistem pemikiran ini merupakan suatu nilai. Oleh karena itu, Pancasila memberikan dasar-dasar yang bersifat fundamental dan universal bagi manusia baik dalam hidup bermasyarakat, berbangsa, dan bernegara. Bila dijabarkan dalam kehidupan yang nyata pada masyarakat, bangsa maupun negara maka nilai tersebut dijabarkan dalam suatu norma-norma yang jelas, yaitu norma moral dan norma hukum atau sistem perundangan yang berlaku di Indonesia. Istilah nilai dalam bidang filsafat dipakai untuk menunjuk kata benda abstrak "keberhargaan" atau "kebaikan", dan kata kerja yang artinya suatu tindakan kejiwaan tertentu dalam menilai atau melakukan penilaian (Yassa, 2018).

Masih terkait dengan nilai atau aksiologi, maka Pancasila dipandang dalam konstelasi historisnya sebagai sebuah prinsip yang menggunakan model pendekatan filsafat jalan tengah (Sutono, 2017). Filsafat jalan tengah adalah salah satu penegasan bahwa kebenaran akhir tidak terletak pada kebenaran-kebenaran yang 
dikandung dalam sebuah ekstrimitas melainkan dalam kedua ekstrimitas itu kebenaran dapat ditemukan. Nilai-nilai dalam Pancasila termasuk nilai etik atau nilai moral merupakan nilai dasar yang mendasari nilai intrumental dan selanjutnya mendasari semua aktivitas kehidupan masyarakat, berbagsa, dan bernegara.

Nilai-nilai kemanusiaan bangsa Indonesia bukan hanya nilai-nilai kebenaran, keindahan, dan kebaikan, tetapi masih ditambah ciri khas adil dan beradab. Kemanusiaan yang beradab tidak memisahkan kemampuan akal dari rasa dan kehendak, tetapi menyatukannya dalam kerjasama. Kerjasama akal, rasa, dan kehendak disebut budi atau kepercayaan-keyakinan. Budi dapat mengenal dan memahami nilai religius sebagai kenyataan mutlak. Nilai religius meliputi nilai-nilai keabadian dan kesempurnaan yang memunyai sifat mutlak dan tetap atau tidak berubah. Kemanusiaan yang adil meliputi hubungan keadilan selengkapnya, yaitu adil pada diri sendiri, masyarakat dan negara, serta pada Tuhan sebagai asal mula manusia (Notonagoro, 1980:91).

Secara aksiologis, bangsa Indonesia merupakan pendukung nilai-nilai Pancasila (subscriber of Pancasila value), yaitu bangsa yang berketuhanan, yang berkemanusiaan, yang berpersatuan, yang berkerakyatan dan berkeadilan sosial. Pengakuan, penerimaan dan pernghargaan atas nilainilai Pancasila itu nampak dalam sikap, tingkah laku, dan perbuatan bangsa Indonesia sehingga mencerminkan sifat khas sebagai Manusia Indonesia.

Pancasila secara aksiologis merupakan sebuah bentuk philosophical system yang secara esensial menempatkan manusia sebagai subjek utama dan menjadi dasar dalam memahami semua realitas yang ada. Filsafat Pancasila memenuhi syarat-syarat logis rasional, dapat dipahami oleh akal sehat dan sesuai dengan prinsipprinsip dalam pengetahuan ilmiah. Pancasila memperoleh makna yang lebih luas yang merupakan salah satu usaha-usaha rasional 
dan filosofis untuk menentukan bagaimana Pancasila yang seharusnya yang memang identik dengan jati diri ke-Indonesiaan sebagai causa materialis dari Pancasila. Sebagai sebuah pemikiran filsafat, Pancasila hadir sebagai bentuk filsafat jalan tengah. Sebagai sebuah filsafat jalan tengah, Pancasila mampu melahirkan pemikiran filosofis yang tetap mengakui dimensi aktualitas manusia dengan segala potensinya tetapi tetap dalam pijakan identitas ke Indonesiaan yang kuat. Oleh karena itulah eksistensi Filsafat Pancasila sangat dibutuhkan dalam dinamika pemikiran kefilsafatan yang tetap berlandaskan pada kejatidirian manusia Indonesia yang sesungguhnya

\subsection{Penjabaran Makna dan Nilai Pancasila.}

Filsafat aksiologi Pancasila menjadi sebuah pesan bahwa, nilai dari Pancasila merupakan sebuah kebenaran yang hidup dan dihidupi oleh seluruh pengikutnya (masyarakat Indonesia). Pancasila menjadi ilham sekaligus menjadi tolok ukur pelaksanaan norma yang dibenarkan. Pada pengamalannya, sifat/perilaku Pancasila tidak selalu dapat diukur dengan akurat. Maka dari itu, aksiologi Pancasila perlu dijabarkan ke dalam butir-butir makna dan nilai yang lebih relevan terhadap perilaku individu sehari-hari.

Sebelum menguraikan makna Pancasila, perlu diketahui terlebih dahulu arti dari kata Pancasila itu sendiri. Muhammad Yamin (dalam Kaelan, 2002), menjelaskan Pancasila secara leksikal terbagi atas dua arti yakni panca yang berarti lima, dan syila yang berarti alas atau dasar. Syila dalam sudut pandang lain juga diartikan sebagai peraturan tingkah laku yang baik atau penting. Pengertian tersebut menjadi inspirasi Muh. Yamin, Ir. Soekarno, dan tokoh pengusul dasar negara lainnya dalam mencetuskan gagasan, tentang lima dasar negara Indonesia. Dasardasar negara Indonesia dituangkan ke dalam ke-lima sila Pancasila dengan maknanya masing-masing. 
Sila pertama, Ketuhanan yang maha esa. Sila pertama ini mendasari dan menjiwai sila-sila lainnya. Hal tersebut didasarkan pada hakikat bahwa, pendukung pokok negara adalah manusia, karena negara adalah sebagai lembaga hidup bersama sebagai lembaga kemanusiaan dan manusia adalah sebagai makhluk tuhan yang maha esa, sehingga adanya manusia sebagai akibat adanya tuhan yang maha esa sebagai kausa prima. tuhan adalah sebagai sebagai asal mula segala sesuatu, adanya tuhan adalah mutlak, sempurna dan kuasa, tidak berubah, tidak terbatas serta pula sebagai pengatur tata tertib alam (Notonegoro, 1975).

Makna sila ketuhanan yang maha esa dalam konteks kehidupan bernegara mengandung arti pengakuan adanya kausa prima (sebab pertama). Tiap masyarakat memegang teguh intisari nilai keagamaan yang diyakininya. Negara harus menjamin kenyamanan penduduk dalam memeluk agama sekaligus tidak memaksa warga negara untuk beragama. Inilah yang disebut sebagai kebebasan ber-agama. Sila pertama juga mengandung makna toleransi antarciptaan tuhan. Toleransi dengan tidak membatasi hak ibadah orang lain atau menistakan keyakinan agama lainnya.

Sila kedua, kemanusiaan yang adil dan beradab. Sila ini tidak terlepas dari pandangan bahwa negara adalah Lembaga kemanusiaan yang diadakan oleh manusia (Notonegoro, 1975). Sila ini menitikberatkan pada kesetaraan kedudukan, maupun peran manusia terhadap manusia lainnya. Rakyat sebagai unsur pokok negara bertujuan untuk mewujudkan keadilan bersama, yakni keadilan dalam hidup bersama sebagai makhluk individu dan makhluk sosial. Maka sila kemanusiaan yang adil dan beradab, menjunjung tinggi kemerdekaan sebagai hak segala bangsa. Maka, kedalian dan peradaban yang kuat harus diwujudkan.

Sila ketiga, persatuan Indonesia. Manusia sebagai mahluk sosial dengan kepentingan individunya, haruslah mewujudkan 
persatuan dan dalam suatu persekutuan hidup. Sila persatuan Indonesia berjalan atas nasionalisme dan kecintaan terhadap tanah air. Menghilangkan dominasi kuatan atau kekuasan, keturutan dan perbedaan warna kulit. Persatuan Indonesia dimaknai sebagai rasa senasib dan sepenanggungan yang tercipta diantara bangsa Indonesia

Sila keempat, kerakyatan yang dipimpin oleh hikmat kebijaksanaan dalam permusawaratan perwakilan. Hakikat utama dari sila keempat ini adalah demokrasi. Permusyawaratan berarti mengusahakan putusan bersama seara bulat, untuk kemudian diambil tindakan Bersama. Dalam melaksanakan putusan, dibutuhkan kejujuran bersama. Sila keempat ini mengandung makna bahwa, segala kepentingan harus didasarkan kepada rakyat umum (bukan individu/golongan), dan proses untuk mencapai itu adalah melalui musyawarah. Disini terlihat bahwa Pancasila menjamin kehidupan sosial.

Sila kelima, keadlian sosial bagi seluruh rakyat Indonesia. Kemakmuran yang merata bagi seluruh rakyat dalam arti dinamis dan meningkat merupakan amal dari keadilan sosial. Seluruh kekaayan alam dan potensinya hendaknya digunakan bagi kebahagiaan seluruh masyarakat. Tidak ada klasterisasi, tidak ada kasta, dan tidak ada tingkatan dalam memperoleh hak-hak sebagai individu. Negara menjamin kesetaraan dalam segala lini kehidupan masyarakat.

Adapun nialai-nilai yang terkandung di dalam sila-sila Pancasila sebagaimana diuraikan Kaelan (2002) adalah sebagai berikut: Sila Ketuhanan Yang Maha Esa terkandung nilai religius yaitu; 1) keyakinan terhadap adanya Tuhan Yang Maha Esa dengan sifat-sifat-Nya yang maha sempurna, maha kasih, maha kuasa, maha adil, maha bijaksana, dan lain-lain sifat yang suci, 2) ketaqwaan adanya Tuhan Yang Maha Esa menjalankan semua perintahnya dan menjauhi segala larangannya. Sila Ketuhanan 
Yang Maha Esa sebagai sumber ajaran moral dasar (basic morality). Apabila ditelaah secara mendalam terhadap definisi filsafat hidup atau weltanschauung, jelaslah bahwa sesungguhnya di dalam kerangka pengertian filsafat hidup telah dipermasalahkan pula apa yang disebut dengan ajaran nilai (doctrine of value).

Salah satu obyek yang dibahas dalam filsafat hidup adalah menyangkut persoalan moral dalam arti moral dasar. Menurut Muhammad Rasjidi (Kaelan, 2002) yang dimaksud moral dasar ialah suatu aturan yang mendasar, yang kita rasakan tidak mungkin dapat menyangkalnya, Oleh karena itu ia dapat dijadikan pedoman kita dalam keadaan yang berbeda-beda. Notonagoro (Kaelan, 2002) menyatakan bahwa hakikat filsafat Pancasila itu merupakan bentuk pemadatan atau kristalisasi dari keyakinan hidup beragama bangsa Indonesia serta adat istiadat dan kebudayaan bangsa. Sehingga jika dianalisa maka 'moral dasar' yang terkandung dalam Filsafat Pancasila menyatakan bahwa 'dengan singkat haruslah dikatakan' bahwa ketuhanan adalah dasar dan tujuan dari seluruh kesusilaan. Tanpa ketuhanan tidak mungkin ada kesusilaan yang berkembang batul-betul.

Sila Kemanusiaan yang adil dan beradab terkandung nilainilai kemanusiaan yaitu; 1) pengakuan adanya martabat manusi, 2) perlakuan yang adil terhadap sesama manuasia, 3) pengertian yang beradab yang memiliki daya cipta, rasa karsa, dan keyakinan sehingga jelas adanya perbedaan antara manusia dan hewan. Sila Persatuan Indonesia terkandung nilai-nilai persatuan antara lain; 1) persatuan bangsa yang mendiami wilayah Indonesia, 2) Indonesia adalah bangsa yang terdiri atas berbagai suku yang mendiami wilayah Indonesia sehingga persatuan sangat perlu untuk menyatukannya atau pengakuan terhadap "Bhinneka Tunggal Ika".

Sila Kerakyatan yang dipimpin oleh hikmat kebijaksanaan dalam permusyawaratan/perwakilan terkandung nilai kerakyatan antara lain: 1) kedaulatan negara adalah ditangan rakyat, 2) 
pimpinan kerakyatan adalah hikmat kebijaksanaan yang dilandasi akal sehat, 3) warga negara dan warga masyarakat Indonesia mempunyai kedudukan, hak, kewajiban yang sama, 4) musyawarah untuk mufakat. Sila Keadilan sosial bagi seluruh rakyat Indonesia terkandung nilai sosial antara lain: 1) perwujudan keadilan social dalm kehidupan sosial atau kemasyarakatan meliputi seluruh rakyat Indonesia, 2) keadilan dalam kehidupan sosial meliputi bidangbidang ideology, politik, ekonomi, sosial kebudayaan dan pertahanan keamanan nasional, 3) cita-cita masyarakat adail makmur, material,dan spiritual yang merata bagi seluruh rakyat Indonesia, 4) keseimbangan antara hak dan kewajiban dan menghormati hak orang lain, cinta akan kemajuan dan pembangunan.

\subsection{Disrupsi Pembelajaran di Era Digital}

Kata disrupsi akhir-akhir ini muncul beriringan dengan istilah era Industri 4.0. Dalam kamus besar bahasa Indonesia, kata "disrupsi" diartikan sebagai "hal tercabut dari akarnya". Fenomena disruption (disrupsi), merupakan situasi pergerakan suatu hal yang tak lagi linier. Sesuatu yang mengalami disrupsi masih berada dalam jalurnya, namun muncul pergeseran-pergeseran fundamental yang tidak selalu dapat diamati secara kasat mata. RISTEKDIKTI (2018) memaparkan cri-ciri era disrupsi dapat dijelaskan melalui (VUCA) yaitu Perubahan yang masif, cepat, dengan pola yang sulit ditebak (Volatility), Perubahan yang cepat menyebabkan ketidakpastian (Uncertainty), terjadinya kompleksitas hubungan antar faktor penyebab perubahan (Complexity), Kekurangjelasan arah perubahan yang menyebabkan ambiguitas (Ambiguity). Pada Era ini, teknologi informasi telah menjadi basis atau dasar dalam kehidupan manusia termasuk dalam bidang bidang pendidikan di Indonesia. Sehingga terjadilah kemudian disrupsi pendidikan.

Sitorus (2018) menyebut istilah pendidikan 4.0, untuk mengimbangi era disrupsi (era industri 4.0). Ciri utama pendidikan 
4.0 adalah pemanfaatan teknologi digital dalam proses belajar mengajar (cyber system), sehingga transfer ilmu pengetahuan dan teknologi dapat dilakukan secara kontinyu tanpa harus selalu tatap muka di kelas. Dengan perkataan lain, materi pembelajaran dapat sampai kepada peserta didik setiap waktu tanpa dibatasi ruang dan waktu. Ada beberapa teknik pelaksanaan Pendidikan 4.0 yaitu, (1) Menyiapkan perangkat teknologi digital untuk pelaksanaan Proses Belajar Mengajar (PBM), (2) Menyiapkan kurikulum yang sesuai dengan perkembangan zaman, dan (3) Memastikan tenaga pendidik mempunyai kecakapan dalam memanfaatkan IT untuk pembelajaran.

Menurut Kepala Badan Penelitian dan Pengembangan Kementrian Pendidikan dan Kebudayaan, Totok Supriyatno, menyatakan bahwa terdapat tantangan yang dihadapi oleh para pelaku Pendidikan di era disrupsi, yaitu tantangan pada proses pembelajaran dan penyampaian materi kepada peserta didik (Kompas.com, 2019). Era disrupsi sangatlah memudahkan seseorang dalam mendapatkan informasi yang diinginkan. Pembelajaran bukan lagi tentang proses interaksi siswa dan guru. Pembelajaran telah bergeser menjadi proses tunggal mencari tahu dari segala sumber. Inilah yang dipandang sebagai disrupsi pembelajaran. Gaya maupun cara baru untuk belajar di era digital ini merupakan dampak dari tersedianya produk-produk IPTEK dan tren global yang mengemuka.

Disrupsi pembelajaran merupakan fenomena yang harus disikapi dengan bijak. Sebab, situasi ini tidak semata-mata membawa dampak buruk. Hal-hal positif justru juga muncul dalam fase ini. Salah satunya adalah peluang siswa menyesuaikan diri terhadap teknologi dan informasi secara cepat dan luas. Siswa akan terbiasa mandiri dan tidak bergantung pada orang lain. Namun, guru perlu menyadari pula dampak negatif berikut tantangan yang ditawarkan. 
Adanya kemudahan dalam mengakses informasi menyebabkan peserta didik mudah larut dalam dunia maya, sehingga cenderung memiliki ketertarikan untuk menyendiri. Keadaan yang terjadi seperti ini akan mengurangi hubungan yang humanis antara guru dengan murid, karena telah digantikan teknologi. Selain itu kepekaan dan kemampuan bersosial anak juga terancam terdegradasi. Egosentris akan sangat mudah tumbuh jika akses terhadap lingkungan berkurang atau terbatas. Bagaimanapun juga, internet maupun media online hanyalah tools untuk belajar. Internet bisa saja membuat siswa menjadi genius, namun tidak cukup mampu untuk mendidik siswa menjadi matang secara sosial dan emosional

Fenomena disrupsi pembelajaran ini muncul dan dihidupi oleh peserta didik itu sendiri. Sebagai generasi neo-milenial, mereka memiliki kecendrungan individualistis, berjiwa bebas, mampu multi tasking, dan tentunya sangat akrab dengan teknologi. Dengan pembawaan tersebut peserta didik secara otomatis akan larut pada pusaran disrupsi. Jika tidak demikian, mereka justru akan dikalahkan oleh situasi. Pendidikan secara umum akhirnya mengalami pergeseran karena disrupsi pembelajaran.

\subsection{Tantangan Pancasila dalam Disrupsi Pembelajaran}

Pancasila akan selamanya menjadi cita-cita bangsa Indonesia. Dalam tatanan kehidupan masyarakat yang dinamis, eksistensi Pancasila juga memiliki tantangannya tersendiri. Faktanya, era disrupsi pembelajaran cukup menyulitkan pendidikan Pancasila untuk sampai ke diri peserta didik. Di sisi lain, Pancasila perlu menemukan track baru agar mampu larut bersama fenomena disrupsi pembelajaran yang terjadi. Terdapat beberapa tantangan terkait Pancasila yang perlu ditanggapi oleh para stakeholder pendidikan, dalam era disrupsi pembelajaran. 
Pertama, Pancasila harus tetap menjadi landasan utama dalam pengembangan/pelaksanaan sistem pendidikan nasional. Sistem Pendidikan Nasional merupakan suatu subsistem dari sistem kehidupan nasional, yang berarti bahwa sistem pendidikan nasional merupakan subsistem dari kehidupan berbangsa dan bernegara. Sistem pendidikan nasional bukanlah sesuatu yang bebas nilai dan bebas budaya karena merupakan bagian dari sistem komunitas nasional dan global. Sistem pendidikan harus selalu bersifat dinamis, kontekstual, dan selalu terbuka kepada tuntutan relevansi di semua bidang kehidupan. Sistem pendidikan nasional tidak perlu berisi aturan pelaksanaan terperinci karena yang penting memunyai kejelasan konsep dasar dan nilai-nilai budaya yang menjadi landasan di setiap pelaksanaan jenjang pendidikan (Tilaar, 2001:10).

Landasan aksiologis sistem pendidikan nasional Indonesia adalah Pancasila, karena nilai-nilai budaya Indonesia adalah nilainilai Pancasila. Nilai-nilai Pancasila sebagai landasan aksiologis sistem pendidikan nasional Indonesia merupakan konsistensi landasan ontologisnya. Landasan ontologis sistem pendidikan nasional Indonesia adalah pandangan bangsa Indonesia tentang hakikat keberadaan manusia. Disrupsi pembelajaran membawa tantangan bagi pemangku otoritas bidang pendidikan berikut lapisan-lapisan di bawahnya. Kebijakan pendidikan yang berkenaan dengan pembelajaran harus memperhatikan dan menjaga eksistensi pendidikan Pancasila di sekolah. Regulasi hingga konsep pelaksaanaan penguatan Pancasila, harus diterjemahkan dengan benar, serta direkonstruksi sesuai dengan kebutuhan era disrupsi.

Kedua, Pancasila menjadi filter terhadap informasi maupun paham-paham yang bertentangan dengan nilai luhur bangsa. Hakikat pribadi kebangsaan Indonesia terdiri atas nilainilai hakikat kemanusiaan dan nilai-nilai tetap yang khusus sebagai ciri khas bangsa Indonesia. Nilai-nilai hakikat kemanusiaaan 
menyebabkan bangsa Indonesia dan orang Indonesia sama dengan bangsa lain dan orang bangsa lain. Nilai-nilai ketuhanan, kemanusiaan, persatuan, kerakyatan, dan keadilan dapat menjadi ciri khas bangsa-bangsa lain, tetapi kesatuan rumusannya secara lengkap sebagai Pancasila hanya dimiliki dan menjadi ciri khas bangsa Indonesia (Notonagoro, 1980:93).

Disrupsi pembelajaran memunculkan ruang baru bagi siswa dalam belajar. Ruang yang dimaksud adalah ruang digital. Internet of things yang diprediksi sejak lama, tampak terealisasi lebih cepat dari perkiraan. Manfaat positif internet tentu sangat banyak dirasakan untuk peserta didik, bahkan juga bagi guru. Namun, terdapat ancaman lain dibalik kemudahan-kemudahan tersebut. Mudahnya peserta didik dalam mengakses informasi maupun konten yang tak sewajarnya. Mulai dari informasi hoax, provokasi, kriminal, pornografi, hingga ke konten-konten radikal yang tak sesuai dengan kepribadian bangsa Indonesia. Kajian aksiologi Pancasila telah menempatkan Pancasila sabagai nilai yang dianut dalam menjalani kehidupan. Nila-nilai Pancasila diharapkan mampu menjadi alat kontrol bagi peserta didik dalam mengelola informasi yang beredar di internet.

Ketiga, strategi mengenalkan Pancasila di era digital. Jika Pancasila telah disepakati sebagai alat kontrol terhadap ancamanancaman di ruang digital, maka pertanyaan berikutnya pun muncul. "Bagaimana mengenalkan nilai-nilai Pancasila di era digital, khususnya kepada generasi milenial?”. Pertanyaan ini terdengar sangat sederhana. Namun, untuk menjawabnya diperlukan pemahaman tentang PEMBAHASAN Pancasila dan prinsip pembelajaran secara esensial. Tantangan ini menjadi semakin sulit dengan adanya fenomena pembelajaran dalam jaringan, maupun jarak jauh.

Pancasila sebagai ideologi bangsa Indonesia memegang peranan penting dalam cita-cita luhur bangsa kepada generasi 
milenial. Globalisasi yang dibarengi dengan era disrupsi pembelajaran telah banyak memengaruhi gaya hidup anak bangsa. Tren global baik dalam bidang fashion, teknologi, lifestyle, dan budaya luar dengan sangat mudah diikuti oleh generasi muda Indonesia. Meningkatnya keaktifan di dunia maya membuat generasi Indonesia kian tak mengenali batas-batas kehdidupannya dengan orang di berbagai belahan dunia. Rasa nasionalisme dan cinta tanah air terancam mengalami pengikisan. Tantangan ini hanya mampu dijawab oleh penguatan nilai Pancasila dalam diri generasi muda.

Pemerintah bersama-sama dengan para praktisi dan masyarakat harus mampu mengubah "wajah" Pancasila untuk generasi muda. Mengubah wajah Pancasila dalam hal ini adalah upaya untuk melakukan pengarusutamaan Pancasila. Konsep ini dapat juga diartikan sebagai upayu mengarahkan Pancasila ke dalam segmen-segmen spesifik. Jika konteksnya adalah generasi muda, maka konten maupun narasi tentang nilai Pancasila harus disesuaikan dengan segmen anak muda. Pendidikan Pancasila perlu ditransformasi ke anak muda melalui metode-metode yang up to date dan menghibur. Pancasila tidak boleh menjadi dogma, melainkan harus fleksibel mengikuti karakteristik generasi muda, dan disampaikan melalui cara-cara yang inovatif.

Keempat, nilai Pancasila harus mampu diterjemahkan ke dalam kompetensi operasional. Esensi dari pendidikan tak boleh kehilangan tujuannya dalam pembentukan manusia seutuhnya (Fauzi dkk, 2017). Manusia seutuhnya adalah manusia yang cerdas, berahlak mulia, dan memiliki kecapakan hidup. Sebagai pedoman hidup dan perilaku bangsa, nilai Pancasila tidak hanya cukup untuk dipahami, namun juga harus diterapkan dalam kehidupan seharihari. Disrupsi pembelajaran cukup mengancam peluang bagi guru dalam memberikan pengalaman-pengalaman penerapan nilai Pancasila dalam kehidupan sehari-hari. Terlebih pembelajaran 
Pancasila yang terjadi pada era disrupsi ini terbatas pada hal-hal yang bersifat konseptual.

Maka dari itu, kompetensi dalam pendidikan Pancasila harus digeser. Learning output Pancasila yang masih berada pada ranah pemahaman, harus diarahkan menjadi kemampuan mengaplikasikan. Mengubah dalam hal ini tidak untuk mengurangi makna maupun nilai Pancasila yang harus diajarkan. Namun lebih kepada re-orientasi hasil belajar yang awalnya dilihat melalui skor menjawab soal tentang Pancasila, menjadi observasi terhadap perilaku-perilaku yang dapat diamati. Ada banyak cara yang bisa dilakukan, mulai dari jurnal aktivitias harian, projek sosial, hingga kegiatan-kegiatan kolaboratif lainnya. Proses belajar nilai Pancasila di internet/platform digital tidak lagi ditujukan untuk menguji seberapa banyak peserta didik mengetahui, tapi memastikan seberapa mampu ia mengamalkannya menjadi kegiatan bermanfaat sehari-hari.

\section{PENUTUP}

Pancasila secara aksiologis merupakan sebuah bentuk philosophical system yang secara esensial menempatkan manusia sebagai subjek utama dan menjadi dasar dalam memahami semua realitas yang ada. Kajian aksiologi menerangkan bahwa Pancasila digunakan sumber nilai bagi kehidupan bangsa Indonesia. Dengan kata lain, Pancasila dijadikan sebagai pedoman utama dalam berlaku, beretika, dan mengimplementasikan segala norma dalam tatanan kehidupan bernegara. Sebagai sumber nilai utama dan pendoman hidup bangsa Indonesia, Pancasila memiliki tantangan tersendiri di tengah fenomena disrupsi pembelajaran. Tantangantantangan ini merupakan suatau urgensi yang harus segera ditanggapi dan ditindaklanjuti. Jawaban ini guna mengantisipasi hal-hal desktruktif yang mengancam peserta didik Indonesia. 
Adapun tantangan-tantangan Pancasila di tengah disrupsi pembelajaran antara lain; 1) Pancasila harus menjadi landasan utama sistem pendidikan nasional, 2) Pancasila harus menjadi filter utama dalam menangkal informasi dan paham-paham yang tidak sesuai dengan kepribadian bangsa, 3) strategi mengenalkan nilai Pancasila kepada generasi muda melaui pembelajaran digital, dan 4) reorientasi hasil belajar Pancasila menjadi kompetensikompetensi operasional (kecapakan/perilaku yang dapat diobservasi).

\section{DAFTAR PUSTAKA}

Fauzi, H., Islam, U., Sunan, N., \& Yogyakarta, K. (2017). Kurikulum 2013 Untuk Total Quality Education Di Indonesia. Jurnal Tarbawi. 14.

Kaelan. (2002). Filsafat Pancasila: Pandangan hidup bangsa Indonesia. Yogyakarta: Paradigma.

Kattsoff, Louis O. (2004). Elements of Philosophy. New York: The Ronald Press Company.

Kompas.com. (2019). Tersedia dalam https://edukasi.kompas.com/read/2019/09/03/15390441/3tantangan-pendidikan-era-disrupsi-teknologi-apasaja?page=all. Diakses pada 21 April 2021.

Notonagoro. (1975). Pancasila Secara Ilmiah Populer. Pantjuran Tudjuh: Jakarta.

Notonagoro. (1980). Pancasila Secara Ilmiah Populer. Jakarta: Pantjuran Tudjuh.

Ohoitimur, Johanis. (2018). Disrupsi: Tantangan bagi Perkembangan Ilmu Pengetahuan dan Peluang bagi Lembaga 
Pendidikan Tinggi. Jurnal RESPONS, Vol. 23, No.02 Hal: 143-166.

RISTEKDIKTI. (2018). Pengembangan Iptek dan Pendidikan Tinggi di Era Revolusi Industri 4.0. Tersedia dalam https://www.ristekbrin.go.id/pengembangan-iptek-danpendidikan-tinggi-di-era-revolusi-industri-4-0/. Diakses pada 21 April 2021.

Sutono, Agung. (2019). Aksiologi Pancasila. Jurnal Ilmiah CIVIS, Volume VIII, No 2

Tilaar. (2001). Manajemen Pendidikan Nasional. Bandung: PT Remaja Rosdakarya.

Yassa, Suarni. (2018). Pendidikan Pancasila ditinjau dari perspektif filsafat (aksiologi). Jurnal Citizenship: Media Publikasi Pendidikan Pancasila dan Kewarganegaraan Vol. 1, No. 1 Tahun 2018. e-ISSN: 2614-0039. Hal. 1-8 


\title{
MEMBANGUN KARAKTER GENERASI ALPHA MELALUI PENERAPAN NILAI-NILAI PANCASILA SEBAGAI SENJATA PAMUNGKAS KETAHANAN NASIONAL
}

\begin{abstract}
I Putu Yoga Purandina.
Sekolah Tinggi Agama Hindu Negeri Mpu Kuturan Singaraja yogapurandina@stahnmpukuturan.ac.id
\end{abstract}

\section{PENDAHULUAN}

Belakangan ini kita telah memasuki era Society 5.0 yang ditandai dengan munculnya berbagai Star-Up terkenal di berbagai negara. Secara ekonomi, Star-Up merupakan perusahan rintisan yang baru memulai usahanya di bawah lima tahun, yang memiliki prospek yang baik. Namun kemudian Star-Up mengalami perubahan makna, tidak hanya perusahan risntisan yang memiliki prospek baik, melainkan perusahaan atau usaha yang baru berjalan atau rintisan yang menerapkan inovasi teknologi untuk menjalankan core business-nya dan menjadi solusi baru dalam pemecahan permasalahan yang dihadapi di tengah-tengah masyarakat (Setiyani et al., 2020).

Beberapa Star-Up yang muncul di Indonesia seperti Gojek, Tokopedia, Traveloka, Bukalapak, dan bahkan Ruang Guru yang merupakan perusahan penyedia aplikasi belajar secara daring 
bagi anak-anak generasi $\mathrm{Z}$ dan Alpha. Star-Up ini di samping merupakan sebuah inovasi yang memanfaatkan teknologi, yang paling penting adalah dapat membantu, meringankankan, memudahkan kehidupan manusia sendiiri. Sebut saja Gojek yang kini menjadi kebutuhan pokok manusia terutama di Indonesia. Dengan aplikasi Gojek yang di dalamnya terdapat berbagai fitur penyedia jasa layanan selain mengantarkan orang ke mana saja, terdapat pula GoFood, GoMart, GoPay, GoGames, GoTik, Go Play, GoSend, GoCar, GoBox, GoClean, dll. Masyarakat merasa terbantu dengan adalanya berbagai fitur layanan ini, apalagi di tengah Pandemi COVID-19 ini (Adi, 2020).

Tidak dapat dipungkiri bahwa kehidupan manusia tidak dapat lepas dari jangkauan Teknologi Informasi yang terus berkembang dengan pesatnya. Ditandai dengan Revolusi Industri 4.0, dunia industri telah memanfaatkan dan menggunakan teknologi internet atau digital. Hampir di setiap perusahaan telah menggunakan sistem digitalisasi untuk peningkatan dan percapatan produktivitas ataupun kecapatan layananan. Kemudian memasuki Era Society 5.0 ini, terasa di segala lini kehidupan tidak dapat lepas dari perkembangan Teknologi Informasi ini. Bahkan belakangan teknologi Artificial Intelligences mulai banyak bermunculan, seperti Google Assistant, Turnitin, Grammarly, Quillbot, dll. Memang seperti yang dijelaskan di muka, teknologi tentu dapat memecahkan berbagai permasalahan manusia. Namun di balik itu, tentu ada permasalahan baru yang muncul. Pada setiap kebaikan tentu ada keburukan, dibalik suatu yang positif tentu ada yang negatif. Hal itu merupakan suatu kewajaran, tergantung dari manusia itu sendiri yang harus bijak menyikapinya (Haryanti, 2019).

Kita kesampingkan dulu manfaat dan hingar bingar teknologi ini. Coba kita masuki sisi sebaliknya, sisi yang menunjukkan masalah baru yang muncul dari perkembangan Teknologi Informasi ini dan dapat membuat hati kita miris. Era 
Society 5.0 ini merupakan era disruptif dimana terjadinya perubahan yang mendasar secara global terhadap kebiasaan yang selama ini terjadi atau dilakukan. Banyak peran yang bisa dianggap bertahun-tahun bahkan berpuluh-puluh tahun dikenal begitu adanya oleh halayak luas, mulai tergantikan oleh peran baru (Septiawan et al., 2020). Sehingga sesungguhnya Era Society 5.0 ini merupakan era perubahan yang menggalkan cara-cara lama kemudian berlaih ke cara-cara baru yang dianggap lebih efisien yang dilakukan saat ini dengan bantuan teknologi dan informasi. Era baru ini didengungkan dan diperkenalkan untuk menyadarkan kita semua jika perubahan ini nyata dan signifikan (Hidayatullah, 2020).

Adapun berbagai permasalahan atau tantangan yang muncul belakangan ini bagi generasi milenial, Z, dan Alpha adalah sebagai berikut:

a. Banyak dan mudahnya informasi yang bersebaran di dunia maya membuat kita sulit membedakan mana informasi atau data yang benar dan bisa dimanfaatkan (Adi, 2020).

b. Komunikasi yang terjadi tidak terhalang ruang dan waktu, sehingga dapat berkomunikasi dan berinteraksi secara global sehingga jika tidak mampu berkomunikasi secara global tentu tidak akan dapat memanfaatkan teknologi informasi ini.

c. Hal yang dianggap konvensional akan mulai ditingggalkan, sehingga hal ini dapat mengancam budaya luhur yang telah diwariskan seblumnya. Generasi milenial akan mulai meninggalkan budaya luhurnya dan menggantikannya dengan budaya baru yang sesuai dengan perkembangan zaman.

d. Perkembangan AI (Artificial Intilegent) saat ini begitu pesat sehingga peran-peran manusia akan mulai tergantikan. Sehingga para milenial ini akan bersaing dalam bidang pekerjaan itu sendiri dengan teknologi.

e. Manusia yang semakin bersifat individual karena telah mampu menggunakan teknologi dan informasi secara mandiri tanpa 
memerlukan pertolongan orang lain. Hampir semua bisa dilakukan dengan mudah dengan perkembangan teknologi informasi (Purandina, 2020a).

Tantangan atau permasalahan ini harus mampu ditanggulangi sehingga para kaum milenial, Z, dan Alpha tidak terjebak di dalam permasalah-permasalahan ini. Tidak hanya tugas kaum milenial sendiri yang harus memcahkan permaslahan ini, namun semua pihak (stake holder) juga harus mampu mencarikan solusi atas permasalahan ini. Terutama dunia pendidikan harus bersiap dan memulai sebuah inovasi pendidikan yang nantinya mampu menyiapkan para milenial ini sehingga dapat bersaing di Era Society 5.0. Terutama untuk pendidikan karakter, haruslah dikuatkan dari sejak dini.

Khususnya untuk generasi Alpha pendidikan karakter ini haruslah ditumbuhkan dari sejak dini. Generasi Alpha yang ratarata kelahiran tahun 2010 - 2021 ini, yang memiliki kisaran umur 0 - 11 tahun (Assingkily et al., 2019). Sehingga penumbuhan karakter ini dapat dilakukan secara maksimal, dan nantinya dapat memiliki pribadi yang adiluhung sebagai masyarakat Indonesia yang memiliki jati diri, kepribadian yang baik, bergaul di dunia Internasional, mengharumkan dan membanggakan Bangsa Indonesia di kancah Internasional. Generasi ini juga harus mampu mempertahankan pribadi Bangsa Indonesia yang adiluhung tersebut dari berbagai pelemahan-pelemahan baik dari dalam ataupun dari luar yang mana belakangan ini marak dilakukan melalui Dunia Digital (Purandina \& Winaya, 2020a).

Bangsa Indonesia sesungguhnya telah memiliki senjata ampuh untuk menangkal berbagai rongrongan pelemahan bangsa, baik dari dalam maupun dari luar Bangsa Indonesia sendiri. Alat ampuh ini kita sebut dengan Pancasila. Pancasila merupakan Ideologi Bangsa Indonesia, dasar negera serta pedoman yang kuat untuk mencapai tujuan negara. Pancasila sendiri digali dari dalam kehidupan historis Bangsa Indonesia sendiri yang menjadi sebuah 
jati diri Bangsa Indonesia sendiri (Fajarini, 2014). Sehingga dipandang sangat ampuh jika nilai-nilai Pancasila ini ditanamkan sebagai penumbuhan karakter generasi Alpha. Jangan sampai generasi Alpha keluar dari jalur jati diri, atau karakter Bangsa Indonesia sendiri akibat pengaruh budaya luar yang tidak sesuai dengan karakter Bangsa Indonesia

\section{PEMBAHASAN}

Pancasila merupakan Ideologi Bangsa Indonesia yang menjadi sebuah pemikiran atau gagasan pokok dalam kehidupan berbangsa dan bernegara. Ideologi tentunya memiliki posisi sentral dalam berbangsa dan bernegara yaitu dapat memeperkuat dan memperdalam identitas bangsa. Pancasila sendiri dirumuskan oleh panitia sembilan dan berdasarkan atas pidato Ir. Soekarno pada tanggal 1 Juni 1945 (Dewantara et al., 2019). Pancasila memiliki beberapa kedudukan dalam kehidupan berbangsa dan bernegara di Indonesia.Kedudukan itu seperti Pancasila sebagai jiwa bangsa Indonesia,Pancasila sebagai kepribadian bangsa Indonesia, Pancasila sebagai pandangan hidup bangsa Indonesia, Pancasila menjadi dasar negara,Pancasila sebagai sumber dari segala hukum yang ada di Indonesia,Pancasila sebagai perjanjian luhur bangsa Indonesia ketika mendirikan negara, dan Pancasila sebagai cita-cita bangsa. Kedudukan inilah yang menjadikan Pancasila menjadi sangat penting bagi bangsa Indonesia. Kedudukan ini juga dapat diartikan bahwasannya Pancasila merupakan suatu landasan bagi bangsa Indonesia dalam melaksanakan segala aspek yang menyangkut kehidupan berbangsa dan bernegera.

Selain itu, Pancasila juga berfungsi sebagai penunjuk arah dalam kehidupan bernegara Indonesia. Sama seperti kapal tanpa kompas, yang tidak tahu akan kemana arah arus membawanya, Republik ini juga akan sama seperti itu apabila tidak adanya penunjuk arah, yaitu Pancasila. Pancasila juga mengandung nilai- 
nilai sejarah di dalamnya karena Pancasila merupakan suatu perjanjian yang dibuat oleh para pendiri bangsa ini ketika mendirikan Republik Indonesia ini. Hal-hal inilah yang membuat Pancasila memiliki fungsi dan juga kedudukan yang sangat penting bagi bangsa Indonesia (Febriansyah, 2017).

Pancasila lahir, digali dari kehidupan Bangsa Indonesia sendiri. Melalui historical panjang perdaban Bangsa Indoensia dari masa kejayaan kerajaan Hindu-Budha hingga pada masa kolonialisme. Pancasila terdiri dari 5 (lima) sila yaitu:

1. Ketuhanan yang Maha Esa

2. Kemanusiaan yang Adil dan Beradab

3. Persatuan Indonesia

4. Kerakyatan yang Dipimpin oleh Hikmat Kebijaksanaan dalam Permusyawaratan, Perwakilan

5. Keadilan Sosial bagi Seluruh Rakyat Indonesia

Kelima sila ini sesungguhnya telah hidup secara turun temurun di bumi Indonesia ini. Unsur-unsur ini telah hidup di hati nurani Bangsa Indoensia, di setiap insan yang lahir dan tumbuh di tanah air Indonesia ini. Sejaranh Bangsa Indonesia telah memberikan bukti bahwa bukti yang dapat kita cari dalam berbagai adat istiadat, tulisan, bahasa, kesenian, kepercayaan, agama dan kebudayaan pada umumnya (Sunoto, 1984). Dengan rinci Sunoto menunjukkan fakta historis, diantaranya adalah:

1. Ketuhanan Yang Maha Esa : bahwa di Indonesia tidak pernah ada putus-putusnya orang percaya kepada Tuhan.

2. Kemanusiaan yang adil dan beradab : bahwa bangsa Indonesia terkenal ramah tamah, sopan santun, lemah lembut dengan sesama manusia.

3. Persatuan Indonesia: bahwa bangsa Indonesia dengan ciricirinya guyub, rukun, bersatu, dan kekeluargaan. 
4. Kerakyatan yang dipimpin oleh hikmat kebijaksanaan dalam permusyawaratan/perwakilan: bahwa unsur-unsur demokrasi sudah ada dalam masyarakat kita.

5. Keadilan social bagi seluruh rakyat Indonesia: bahwa bangsa Indonesia dalam menunaikan tugas hidupnya terkenal lebih bersifat social dan berlaku adil terhadap sesama.

Sehingga tidak perlu diragukan lagi jika Pancasila sesungguhnya digali dari kehidupa Bangsa Indonesia sendiri. Namun permaslahannya bagaimana caranya untuk tetap menghidupkan Pancasila ini di dalam hati yang mengalir ke dalam segala derap lamgkah Bangsa Indonesia selanjutnya. Inilah perlu adanya meneladani dan menerapkan nilai-nilai Pancasila di segal lini kehidupan berbangsa. Adapun nilai-nilai yang tertuang di dalam ke lima sila Pancasila adalah:

1. Nilai Ketuhanan; nilai yang mengandung pengakuan atas keberadaan Tuhan sebagai pencipta lam semesta beserta isinya. Manusia Indonesia beriman yaitu meyakini adanya Tuhan yang diwujudkan dalam ketaatan kepada Tuhan Yang Maha Esa. Nilai yang terkandung di dalamnya:

a. Mengimani adanya Tuhan yang Maha Esa dan mengikut perintah serta larangannya

b. Saling menghormati dan menghargai antar pemeluk agama

c. Memiliki rasa toleransi dalam kehidupan beragama

d. Tidak memaksakan kehendak antar umat beragama

e. Tidak mencemooh dan merendahkan agama orang lain

2. Nilai Kemanusiaan; nilai yang mengadung rumusan sifat keseluruhan budi manusia Indonesia yaitu mengakui kedudukan manusia sederajat dan sama. Serta mempunyai hak dan kewajiban yang sama sebagai warga negara yang dijamin oleh negara. Nilai yang terkandung di dalamnya adalah:

a. Seluruh rakyat Indonesia memiliki hak yang sama di mata hukum, agama, masyarakat, dan lainnya 

b. Tidak ada perbedaan sosial antara sesama rakyat Indonesia
c. Mengutamakan sikap tenggang rasa dan saling tolong menolong
d. Menjunjung tinggi nilai kemanusiaan antar rakyat Indonesia
e. Saling menghargai pendapat

3. Nilai Persatuan; nilai ini merupakan perwujudan paham kebangsaan Indonesia yang mengatasi paham perseorangan, golongan, suku, suku bangsa. Serta mendahulukan persatuan dan kesatuan bangsa sehingga tidak terpecah belah oleh sebab apapun. Nilai yang terkandung di dalamnya adalah:
a. Menggunakan bahasa persatuan Indonesia
b. Memperjuangkan dan mengharumkan nama Indonesia
c. Cinta terhadap tanah air
d. Mengutamakan kesatuan dan persatuan
e. Berjiwa patriotisme di manapun kaki berpijak

4. Nilai Kerakyatan; nilai yang merupakan sendi utama demokrasi di Indonesia berdasar atas asas musyawarah dan asas kekeluargaan. Nilai yang terkandung di dalamnya adalah:
a. Pemimpin bangsa Indonesia harus bijaksana
b. Mengutamakan kekeluargaan
c. Kedaulatan bangsa berada di tangan rakyat
d. Kebijakan dalam mengambil solusi
e. Keputusan bersama harus diambil melalui musyawarah
f. Tidak memaksakan kehendak

5. Nilai Keadilan; nilai yang merupakan salah satu dari tujuan negara yaitu mewujudkan tata masyarakat Indonesia yang adil dan makmur berdasarkan Pancasila. Nilai yang terkandung di dalamnya adalah:

a. Harus menerapkan perilaku adil dalam bidang ekonomi, sosial, dan politik

b. Harus menghormati hak dan kewajiban setiap orang

c. Perwujudan keadilan sosial bagi bangsa Indonesia

d. Menggapai tujuan adil dan makmur 
e. Mendukung kemajuan dan pembangunan Indonesia (Suparman, 2012)

Sungguh luar biasa nilai-nilai yang terkandung pada Pancasila ini. Jika nilai-nilai ini dapat diterapkan sebagai jati diri Bangsa Indonesia ke depannya tentu akan menjadi sebuah senjata yang ampuh, perisai yang kuat untuk melawan rongrongan yang mengancam ketahanan nasional. Generasi Alpha sebagai generasi terkini yang tumbuh di bumi Indonesia ini hendaknya ditanamkan nilai-nilai pancasila ini melalui pendidikan karakter. Pendidikan karakter yang berlandaskan Pancasila yang nantinya mendarah daging dalam derap langkah generasi penerus bangsa ini.

Di zaman yang serba cepat ini ancaman tentu akan semakin dahsyat menerpa Bangsa Indonesia. Baik melalui dunia maya atau digital, begitu pula dari dunia nyata. Maraknya terror bom yang dilakukan oleh para terrorist yang berawal dari ajakan atau perekrutan di media digital. Begitu pula terjadinya perpecahan di media digital yang berimbas ke dunia nyata (Fitriarti, 2019). Sejatinya penumbuhan karakter melalui nilai-nilai Pancasila inilah yang harus segera diupayakan. Mulai dari lingkungan keluarga, sekolah, hingga pada lingkungan masyarakat.

Terdapat 18 nilai-nilai karakter yang dapat ditumbuhkan melalui internalisasi nilai-nilai pancasila ini. Pemerintah sebenarnya sudah sangat memahami mengenai pendidikan karakter ini. Presiden Ir. H. Joko Widodo telah mengeluarkan Peraturan Presiden Nomor 87 Tahun 2017 tentang penguatan Pendidikan Karakter. Perpres ini memiliki tujuan untuk membentuk pribadi bangsa yang berbudaya melalui penguatan nilai-nilai karakter yang yang digali dari budaya bangsa Indonesia sendiri. Penguatan Pendidikan Karakter yang disingkat PPK ini adalah merupakan upaya pemerintah di bawah satuan pendidikan untuk memeperkuat karakter peserta dididk melalui harmonisasi olah hati, olah pikir, 
olah raga, melibatkan tiga satuan pendidikan yaitu sekolah, keluarga dan masyarakat (Purandina \& Winaya, 2020b).

Kemudian ditindaklanjuti dengan Permendikbud Nomor 20 Tahun 2018 tentang Penguatan Pendidikan Karakter (PPK), memperkuat pendidikan karakter yaitu dengan melaksanakan pendidikan karakter yang berdasar asas Pancasila dengan menanamkan sikap religious, jujur, toleran, disiplin, bekerja keras, kreatif, mandiri, demokratis, rasa ingin tahu, semangat kebangsaan, cinta tanah air, menghargai prestasi, komunikatif, cinta damai, gemar membaca, peduli lingkungan, peduli sosial, dan bertanggung jawab. Semua sikap tersebut merupakan penjabaran dari 5 (lima) nilai pokok yaitu religiusitas, nasionalisme, kemandirian, gotong royong, dan integritas (Purandina, 2020b)

Kemudian untuk menerapkan nilai-nilai Pancasila sebagai bagaian pendidikan karakter haruslah dilakukan dari aspek terkecil dalam sebuah komunitas yaitu keluarga. Orang tua memiliki peran sentral dalam penumbuhan karakter ini. Berikuti ini merupakan beberapa kegiatan yang dapat dilakukan untuk menerpakan nilainilai Pancasila untuk anak:

1. Sila Pertama;

a. Mengajak anak beribadah bersama

b. Bersyukur, berdoa sebelum makan dan tidur

c. Bercerita tentang kisah kisah kepahlawanan dalam ajaran agama

2. Sila Kedua;

a. Berkumpul dan berinteraksi bersama sanak saudara, teman, atau tetangga

b. Mengajak anak menolong antar sesama

3. Sila Ketiga;

a. Memberikan pemahaman kepada anak bahwa Indonesia terdiri dari ribuan pulau yang terdiri dari berbeda suku dan daerah sehingga paham terhadap toleransi 
b. Mengajarkan anak tentang kebersamaan, makan bersama, bermain bersama, dan saling berbagi bersama teman.

4. Sila Keempat;

a. Mengajarkan anak untuk berani mengungkapkan pendapatnya dengan tidak memaksakan kehendanya sedikitpun

b. Melakukan diskusi terhadap berbagai permasalahan yang dihadapi mulai dari hal yang sederhana.

5. Sila Kelima;

a. Mengajarkan anak untuk selalu berbagi, baik itu mainan, makanan, dll secara asil terhadap saudara atau teman.

b. Mengajarkan anak untuk tidak membeda-bedakan, bersikap adil berbagi sama rata senasib sepenanggungan (BPIP, 2020).

\section{PENUTUP}

Demikianlah pemaparan mengenai Nilai-nilai Pancasila sebagai Senjata Pamungkas Ketahanan Nasional Bangsa Indonesia. Dengan menerapkan nilai-nilai Pancasila ini terhadap generasi Alpha sebagai penerus Bangsa yang saat ini masih sangat belia, sangat baik ditumbuhkan pendidikan karate yang sesuai dengan jati diri, karakter adiluhunh Bangsa Indonesia sendiri. Menerapkan nilai-nilai Pancasila di tengah era society 5.0 ini tentu tidaklah mudah. Begitu derasnya ancaman pelemahan jati diri Bangsa melalui dunia digital misalnya, akan memnyebabkan generasi muda ini menjadi luluh lantak yang kehilangan nyawanya, seperti anak ayam kehilangan induknya.

Sudah sangat tepat jika penumbuhan pendidikan karakter melalui penerapan nilai-nilai Pancasila ini diterapkan mulai dari lingkungan sosial terkecil yaitu keluarga (Irwansyah et al., 2021). Orang tua tentu harus memiliki semangat yang tinggi untuk menanamkan nilai-nilai karakter ini sehingga dapat menyatu di 
dalam hati para generasi Alpha ini. Menumbuhkan karakter sedari kecil ini harus pula dipupuk, dirawat sedemikian rupa, sehingga nantinya akan semakin kuat dan memiliki akar yang kuat untuk menopang segala aktivitas setiap insan penerus bangsa ini. Sehingga menjadi sebuah senjata pamungkas untuk menjaga Bangsa Indonesia sebagai Bangsa yang mampu disegani oleh Bangsa lainnya di dunia ini.

Semoga para orang tua, guru, masyarakat, serta stake holder Bangsa ini menyadari pentingnya senjta pamungkas ini untuk tetap dirawat di dalam hati para generasi penerus. Sungguh sangat disayangkan jika sejata beserta perisai ini tidak ditanamkan dan dirawat pada setiap penerus Bangsa ini. Hal ini akan membawa malapetaka yang tiada tara yang dapat meluluhlantakkan Bangsa Indonesia. Mari kita rawat, kita kuatkan senjata pamungkas kita yang kita sebut dengan Pancasila ini. Merdeka!

\section{DAFTAR PUSTAKA}

Adi, S. W. (2020, October). Peluang \& Tantangan Generasi

Milenial Dalam Menghadapi Era Society 5.0. Jawa Pos Radar Solo.

Anderson, J. E., \& Bunch, H. C. (1989). Agricultural property tax relief: tax credits, tax rates, and land values. Land Economics, 65(1), 13-22. https://doi.org/10.2307/3146259

Anderson, John E. (1993). Use-Value Property Tax Assessment:

Effects on Land Development. Land Economics, 69(3), 263. https://doi.org/10.2307/3146592

Anderson, John E. (2012). Agricultural Use-Value Property Tax Assessment: Estimation and Policy Issues. https://doi.org/10.1111/j.1540-5850.2012.01025.x

Anderson, John E, Giertz, S. H., Shimul, S. N., \& Family, B. (2015). Property Taxes for Agriculture Use-Value Assessment 
and Urbanization across the United States.

Assingkily, M. S., Putro, K. Z., \& Sirait, S. (2019). Kearifan

Menyikapi Anak Usia Dasar di Era Generasi Alpha (Ditinjau dari Perspektif Fenomenologi). Attadib: Journal of

Elementary Education, 3(2), 1-21.

Boonyanam, N. (2019). Agricultural Zoning and Policy Conflict:

Thailand's Experience. In Land Use - Assessing the Past,

Envisioning the Future. IntechOpen.

https://doi.org/10.5772/intechopen.80262

BPIP. (2020). Cara Mudah Menanamkan Nilai-nilai Pancasila Pada Anak Sejak Kecil. Bpip.Go.Id.

Bryant, C. (2017). What Can Agricultural Land Use Planning Contribute to Food Production and Food Policy? International International Journal of Avian \& Wildlife Biology, 2(1). https://doi.org/10.15406/ijawb.2017.02.00009

Darmawan, M. J., \& Tukiman, T. (2020). ANALISIS DIMENSI KETIMPANGAN PEMBANGUNAN ANTAR WILAYAH DI PROVINSI JAWA TIMUR TAHUN 2014-2018.

Dinamika Governance : Jurnal Ilmu Administrasi Negara, 10(1). https://doi.org/10.33005/jdg.v10i1.2045

Dedy Darmawan Nasution. (2020). Tiap Tahun, 60 Ribu Hektare Lahan Pertanian Menyusut | Republika Online.

Dewantara, J. A., Suhendar, I. F., Rosyid, R., \& Atmaja, T. S. (2019). Pancasila as Ideology and Characteristics Civic Education in Indonesia. International Journal for Educational and Vocational Studies, 1(5), 400-405. https://doi.org/10.29103/ijevs.v1i5.1617

Endah Wulantina, S. M. (2019). Persepsi Peserta Didik terhadap Metode Blended Learning dengan Google Classroom. Jurnal Inovasi Matematika, 1(2), 110-121. 
https://doi.org/10.35438/inomatika.v1i2.156

Fajarini, U. (2014). Peranan Kearifan Lokal Dalam Pendidikan Karakter. SOSIO DIDAKTIKA: Social Science Education Journal, 1(2). https://doi.org/10.15408/sd.v1i2.1225

Fauzi, M. R. (2019). Ketimpangan, Pola Spasial, dan Kinerja Pembangunan Wilayah di Provinsi Jawa Timur. Journal of Regional and Rural Development Planning (Jurnal Perencanaan Pembangunan Wilayah Dan PerdesaanJP2WD), 2019(3), 157-171. https://doi.org/10.29244/jp2wd.2019.3.3.157-171

Febriansyah, F. I. (2017). Keadilan Berdasarkan Pancasila Sebagai Dasar Filosofis Dan Ideologis Bangsa. DiH: Jurnal Ilmu Hukum, 13(25), 1. https://doi.org/10.30996/dih.v13i25.1545

Fitriarti, E. A. (2019). Urgensi Literasi Digital Dalam Menangkal Hoax Informasi Kesehatan Di Era Digital.

Metacommunication: Journal of Communication Studies, 4(2), 219. https://doi.org/10.20527/mc.v4i2.6929

Haryanti, R. (2019, January). “Society 5.0”, Solusi Jepang Atasi Defisit Penduduk dan Infrastruktur. Kompas.Com.

Hidayatullah, R. (2020). Pendidikan Musik: Pendekatan Musik Untuk Anak di Era 4.0. CV. Rumah Kayu Pustaka Utama.

Irwansyah, R., Darmayani, S., Mastikawati, M., Saputro, A. N. C., Wihartanti, L. V., Fauzi, A., Arifudin, O., Purandina, I. P. Y., Latifah, E. D., Septiyani, T., Pangestika, R. R., Fatayah, F., Ayuningtyas, P., Lemba, V. C., \& Hartono, R. (2021). PERKEMBANGAN PESERTA DIDIK . In Widina Bhakti Persada Bandung. Widina Bhakti Persada Bandung.

Lin, D. (2020). COVID-19 pneumonia patient without clear epidemiological history outside Wuhan: An analysis of the radiographic and clinical features. Clinical Imaging, 65, 82- 
84.

Liu, D. (2020). COVID-19: The first documented coronaviruspandemic in history. Biomedical Journal, 1-6.

Metzger, J. T. (1996). The Theory and Practice of Equity Planning: An Annotated Bibliography. Journal of Planning Literature, 11(1), 112-126. https://doi.org/10.1177/088541229601100106

Mustofa, M. I., Chodzirin, M., Sayekti, L., \& Fauzan, R. (2019).

Formulasi Model Perkuliahan Daring Sebagai Upaya

Menekan Disparitas Kualitas Perguruan Tinggi. Walisongo

Journal of Information Technology, 1(2), 151.

https://doi.org/10.21580/wjit.2019.1.2.4067

Nordquist, M. (2013). Seeking spatial justice by Edward W. Soja.

Contemporary Political Theory, 12(1), e16-e18.

https://doi.org/10.1057/cpt.2011.40

OECD. (2020). Taxation in Agriculture. In Taxation in Agriculture. OECD. https://doi.org/10.1787/073bdf99-en

Perrin, C., Clément, C., Melot, R., \& Nougarèdes, B. (2020). land Preserving Farmland on the Urban Fringe: A Literature Review on Land Policies in Developed Countries. https://doi.org/10.3390/land9070223

Philippopoulos-Mihalopoulos, A. (2014). The Movement of Spatial Justice. MONDI MIGRANTI, 1, 7-19. https://doi.org/10.3280/mm2014-001001

Purandina, I. P. Y. (2020a). Mengembangkan Literasi Digital pada Anak di Lingkungan Keluarga dengan Penguatan Pendampingan Orang Tua. In Y. Septiawan \& M. B. Muvid (Eds.), Strategi dan Metode Pembelajaran Era Society 5.0 di Perguruan Tinggi (1st ed., p. 149). Goresan Pena.

Purandina, I. P. Y. (2020b). Pendidikan Karakter Tumbuh Subur di 
Lingkungan Keluarga selama Pandemi COVID-19. In

COVID-19: Perspektif Pendidikan (pp. 99-114). Yayasan Kita Menulis.

Purandina, I. P. Y., \& Winaya, I. M. A. (2020a). Berkarakter dalam Literasi Digital : Menjaga Kedamaian Umat di Era Digital. 1-18.

Purandina, I. P. Y., \& Winaya, I. M. A. (2020b). Pendidikan Karakter di Lingkungan Keluarga Selama Pembelajaran Jarak Jauh pada Masa Pandemi COVID-19. Cetta: Jurnal Ilmu Pendidikan, 3(2), 270-290.

https://doi.org/10.37329/cetta.v3i2.454

Relman, E. (2020). Business insider Singapore.

Rustiadi, E. (2001). Pergeseran Menuju Paradigma Baru

Pengembangan Wilayah. Forum Diskusi Pengembangan

Metode, Puslitbang Ketenagakerjaan Dan Ketransmigrasian,

Departemen Tenagakerja Dan Transmigrasi.

Santika, I. G. N. (2019). Pendidikan Karakter: Studi Kasus Peranan Keluarga Terhadap Pembentukan Karakter Anak Ibu Sunah Di Tanjung Benoa. Widya Accarya, 10(1).

https://doi.org/https://doi.org/10.46650/wa.10.1.864.\%25p

Septiawan, Y., Purandina, I. P. Y., Jumari, Tafonao, T., Ramlan, A. M., Dewi, N. P. C. P., Tambuanan, T. S., Zaedun, N., Arlotas, R. K., Suryaningwidi, R., \& Muvid, M. B. (2020). Strategi dan Metode Pembelajaran Era Society 5.0 di Perguruan Tinggi (Y. Septiawan \& M. B. Muvid (eds.)). Goresan Pena.

Setiyani, S., Dasilah, \& Nurcahyo, D. N. (2020). Paradigma Baru Pendidikan Era Disruptif Menuju Masyarakat 5.0. Prosiding

Seminar Nasional Pendidikan Program Pascasarjana

Universitas Pgri Palembang 10 Januari 2020, 747-756.

Soja, E. W. (2008, March). The city and spatial justice. Spatial 
Justice.

Sunoto. (1984). Mengenal Filsafat Pancasila : Pendekatan melalui metafisika logika etika. Hanindita.

Suparman. (2012). Pancasila. Balai Pustaka.

Widyawati Agustin, I., \& Kubota, H. (2012). Changing Physic,

Changing Pattern, and Conflicts of Rural-Urban Fringe Using a Combination Model. J. Basic. Appl. Sci. Res, 2(12), 1272212730 .

Wijaatmaja, A. B. M. (2015). PENDEKATAN PERENCANAAN TATA RUANG WILAYAH DI KOTA DENPASAR - PDF Free Download. Program Pascasarjana Universitas Udayana.

Yuliana. (2020). Corona virus diseases (Covid -19); Sebuah tinjauan literatur. Wellness and Healthy Magazine, 2(1), 187192.

Yunus, H. S. (1990). Searching new strategies for managing and controlling urban land growth: a preliminary outlook on Indonesia. Indonesian Journal of Geography, 20(60), 1-10. https://doi.org/10.22146/IJG.2188

Yunus, H. S. (2005). Manajemen kota : perspektif spasial. 


\title{
MEWUJUDKAN KEBEBASAN PERS YANG BERTANGGUNGJAWAB BERDASARKAN PANCASILA
}

\author{
I Wayan Kotaniartha
}

Fakultas Ilmu Komunikasi dan Bisnis Universitas Dwijendra wayankotaniartha@gmail.com

\section{PENDAHULUAN}

Pers dengan berbagai fungsinya telah menjadi bagian integral kehidupan bangsa Indonesia. Semakin lama peranan pers semakin menentukan bagi perjalanan bangsa di berbagai bidang. Tidak ada dinamika sosial politik yang luput dari perhatian pers, dan tidak ada masalah publik yang tidak dibicarakan melalui ruang publik media. Semua pihak seperti masyarakat, pemerintah, penegak hukum, lembaga legislatif, dan kalangan bisnis berkepentingan dengan pemberitaan pers dan menjadikan ruang publik media sebagai saluran komunikasi dan informasi yang utama.

Problemnya sampai saat ini masih demikian banyak terjadi kesalahpahaman berkenaan dengan berbagai aspek kehidupan pers di berbagai kalangan. Dan tidak terkecuali terjadi dikalangan pers sendiri. Mengingat demikian urgensinya dan peranan pers bagi masyarakat, namun belum diimbangi dengan kesamaan pandangan dan pemahaman berkenaan dengan aspek-aspek kehidupan pers. 
Pada awalnya istilah pers dipahami sebagai wahana komunikasi massa berupa media cetak, terutama surat kabar dan majalah. Terminologi "pers" berasal dari kata press dari bahasa Inggris dan persen dari bahasa Belanda. Kedua kata tersebut berarti "menekan". Kata "menekan" itu merujuk pada mesin cetak kuno yang harus ditekan dengan keras untuk menghasilkan karya cetak pada lembaran kertas.

Makna istilah pers dilihat dari perspektif Kamus Besar Bahasa Indonesia(KBBI), terminology "pers" mempunyai banyak makna, yaitu usaha percetakan dan penerbitan; usaha pengumpulan dan penyiaran berita; penyiaran berita melalui surat kabar, majalah dan radio; orang yang bekerja dalam penyiaran berita; medium penyiaran berita, seperti surat kabar, majalah, radio, televisi dan film.

Saat ini istilah "pers" pada umumnya merujuk pada berbagai jenis media massa, tidak hanya surat kabar, majalah, radio, televisi dan film, tetapi juga internet. Realitas pemahaman tersebut menunjukkan bahwa istilah "pers" terus mengalami dinamika serta perluasan makna seiring dengan perubahan zaman, terutama perkembangan teknologi komunikasi.

Pada Pasal 1 butir 1 Undang - undang Nomor 40 Tahun 1999 tentang Pers terdapat batasan atau definisi yang luas dan sangat proyektif mengenai makna dan pemahaman tentang pers. Dalam Undang-undang tersebut ditegaskan bahwa pers adalah lembaga sosial dan wahana komunikasi massa yang melaksanakan kegiatan jurnalistik meliputi mencari, memperoleh, memiliki, menyimpan, mengolah dan menyampaikan informasi baik dalam bentuk tulisan, gambar, suara serta data dan grafik maupun dalam bentuk lainnya dengan menggunakan media cetak,media elektronik, dan segala jenis saluran yang tersedia

Berangkat dari batasan tersebut maka terminologi pers memiliki dua arti, yaitu dalam arti luas dan sempit. Dalam pengertian secara luas, pers menunjuk pada pranata sosial yang 
melaksanakan aktivitas jurnalistik. Atas dasar itu maka pers di sini merujuk pada kegiatan berpola untuk memenuhi kebutuhan masyakat tentang informasi. Aktivitas atau kegiatan yang berpola tersebut umumnya dilaksanakan oleh lembaga atau pranata yang berorientasi mendapatkan keuntungan (perusahaan pers) ataupun lembaga non profit seperti lembaga swadaya masyarakat.

Dalam arti sempit, pengertian pers merujuk sebagai media komunikasi massa. Media komunikasi massa tersebut merupakan produk kegiatan jurnalistik yang dilakukan oleh perusahaan perusahaan pers ataupun lembaga swadaya masyarakat yang bergerak di bidang pers. Dengan demikian dapat ditegaskan bahwa pers merujuk pada berbagai media komunikasi massa, baik media massa elektronik maupun media massa cetak. Dalam kegiatan sehari - hari, jika kita berbicara tentang pers, maka pada umumnya yang dirujuk adalah makna yang kedua atau makna yang sempit. Dan dalam wacana sehari - hari, istilah pers umumnya digunakan untuk merujuk pada pengertian sebagai wahana/ media komunikasi massa.

Keberadaan pers di Indonesia mengalami perkembangan panjang sesuai dengan perjalanan sejarah bangsa Indonesia, yakni pers dimasa lalu sampai dengan keberadaan pers dimasa sekarang. Eksistensi pers memiliki fungsi dan peran yang sangat penting dalam masyarakat yang demokratis. Pers berperan sebagai mata dan telinga, pemberi isyarat, pemberi tanda-tanda dini, pembentuk opini atau pendapat, dan mengarah agenda masa depan, yang sering disebut sebagai whatsdog.

Dalam Undang-undang No.40 tahun 1999 tentang pers, pada Pasal 3 dinyatakan bahwa pers nasional mempunyai fungsi sebagai media informasi, pendidikan, hiburan dan kontrol sosial. Selain itu pers juga berfungsi sebagai lembaga ekonomi. Pengertian sebagai lembaga ekonomi dimaksudkan bahwa perusahaan pers dikelola sesuai prinsip ekonomi. Hal ini penting agar kualitas pers dan kesejateraan para wartawan dan 
karyawannya semakin meningkat dengan tidak meninggalkan kewajiban sosialnya. Pers adalah sebuah perusahaan yang bergerak di bidang penerbitan. Pers memiliki bahan baku yang diolah sehingga menghasilkan produk yang namanya "berita" yang memiliki nilai jual tinggi. Semakin berkualitas beritanya maka semakin tinggi nilai jualnya. Karena itu Pers juga menyediakan kolom untuk iklan. Pers membutuhkan biaya untuk kelangsungan hidupnya. Berdasarkan uraian di atas maka yang menjadi fokus kajian tulisan ini adalah (1) Bagaimanakah dinamika Pers Indonesia, dan (2) Bagaimanakah implementasi kebebasan Pers yang bertanggungjawab berdasarkan Pancasila

\section{PEMBAHASAN}

\subsection{Dinamika Pers Indonesia}

\subsection{Era Penjajahan dan masa pergerakan nasional}

Pada masa kolonial Belanda keberadaan pers sangat dibatasi dan diancam dengan ketentuan yang ada dalam KUHP (Kitab Undang-undang Hukum Pidana) dengan memberlakukan pasal-pasal karet dan mengontrol dengan ketat eksistensi pers. Keberadaan pers di era pergerakan nasional, setelah lahirnya pergerakan modern yang bernama Budi Utomo yang berdiri tanggal 20 Mei 1908. Surat kabar yang diterbitkan oleh orang Indonesia lebih berfungsi sebagai wahana perjuangan. Pers ketika itu berperan sebagai "terompet" dari organisasi pergerakan orang Indonesia. Peran pers menjadi motivator bangsa Indonesia dalam perjuangan untuk memperbaiki nasib dan posisi bangsa. Terdapat beberapa contoh harian yang terbit pada masa pergerakan, antara lain:, Harian Utusan Hindia, Mingguan Pikiran Rakyat, Fajar Asia, harian Sedio Tomo dan lain-lain.

Eksistensi Pers di era pendudukan Jepang, keberadaannya terfokus sebagai alat pemerintah Jepang dan bersifat memihak pemerintah Jepang. Terdapat beberapa harian ketika itu yang 
muncul antara lain: Sinar Baru di Semarang, Asia Raya di Jakarta, Tjahaya di Bandung dan Suara Asia di Surabaya. Pers nasional di era penjajahan Jepang mengalami pengekangan lebih parah dari zaman Belanda. Tetapi positifnya ada beberapa keuntungan bagi insan pers yang bekerja pada penerbitan Jepang, antara lain: (a) penggunaan bahasa Indonesia makin sering dan luas Karena bahasa Belanda berusaha dihapus oleh Jepang, hal ini yang nantinya membantu bahasa Indonesia digunakan sebagai bahasa nasional (b) adanya pengajaran bagi rakyat agar berpikir kritis terhadap berita yang disajikan oleh sumber resmi Jepang (c) Pengalaman karyawan pers Indonesia bertambah. Fasilitas dan alat yang digunakan jauh lebih banyak daripada pada masa Belanda, Dengan perilaku kejam Jepang dan penderitaan yang dialami rakyat pada masa Jepang memudahkan para pemimpin bangsa memberi semangat untuk melawan penjajah.

\subsubsection{Masa Revolusi Fisik dan Era Demokrasi Liberal}

Pada era tahun 1945-1949 atau era revolusi fisik, peranan pers di saat-saat proklamasi kemerdekaan diproklamirkan, maka peran pers beriring jalan dengan perjuangan rakyat Indonesia. Dan bahkan banyak para jurnalis yang langsung berperan dalam usahausaha proklamasi. Pada era ini pers diklasifikasikan menjadi dua golongan yaitu pertama pers yang terbit di daerah yang masih dikuasai oleh sekutu, kemudian Belanda. Dan yang kedua adalah pers yang terbit di daerah yang dikuasai oleh Republik Indonesia yang kemudian ikut bergerilya.

Selanjutnya pada masa 1949 - 1959 (masa demokrasi liberal), landasan kemerdekaan pers berdasarkan Konstitusi Republik Indonesia Serikat Tahun 1949 dan UUD Sementara 1950. Pada Pasal 19 Konstitusi Republik Indonesia Serikat (RIS) 1949, ditegaskan bahwa "Setiap orang berhak atas kebebasan mempunyai dan mengeluarkan pendapat". Pasal ini juga dicantumkan di dalam UUD Sementara 1950. Keberadaan Pers 
nasional ketika itu sesuai dengan sistem politik liberal yang sangat memberi ruang kebebasan Pers. Peran dan fungsi pers pada masa ini adalah sebagai alat perjuangan kelompok partai atau aliran politik yang saling bertentangan dan menyalahgunakan kebebasan pers

\subsubsection{Masa Demokrasi Terpimpin}

Pada masa tahun 1959-1966 (Era demokrasi terpimpin), ketika Presiden mengeluarkan Dekrit tanggal 5 Juli 1959 yang menyatakan kembali ke UUD 1945, maka upaya melakukan penekanan terhadap pers masih terus berlangsung, yaitu dengan dilakukan penutupan Kantor Berita PIA, Surat kabar Republik, Pedoman, Berita Indonesia, dan Sin Po yang dilakukan oleh penguasa perang Jakarta.

Di Era ini tidak terjadi kebebasan pers, dan pemerintah melakukan kontrol secara tegas setiap kegiatan pers. Pers pada masa itu menganut konsep otoriter. Pers diberi tugas menggerakkan aksi-aksi massa revolusioner untuk mendukung pelaksanaan manipol dan ketetapan pemerintah.

\subsubsection{Di Era Pemerintahan Orde Baru}

Di masa Pemerintahan Orba (1966-1998), dikenal dengan Pers Pancasila dan ditandai dengan dikeluarkannya Undang-undang Pokok Pers No.11 tahun 1966, dengan meninggalkan praktik penekanan pers di masa Orde Lama. Suasana kebebasn pers di era ini hanya berlangsung sekitar 8 tahun, sebab dengan terjadinya "Peristiwa Malari" (Peristiwa Lima Belas Januari 1974) disinyalir disebabkan berita-berita yang terlalu bebas tanpa sensor yang menyiarkan berbagai hal yang dapat menyulut emosi mahasiswa untuk melakukan demontrasi pada pemerintah orde baru. Oleh karena itu beberapa surat kabar dilarang terbit termasuk koran Kompas. Walaupun diijinkan terbit 
kembali setelah permintaan maaf. para jurnalis selalu diingatkan untuk menaati kode etik jurnalistik.

Peran pers sejak peristiwa "Lima Belas Januari” tersebut pers cendrung berperan mewakili penguasa, pemerintah atau Negara. Pers tidak menjalankan fungsi kontrol sosialnya dengan kritis, mirip dengan di masa demokrasi terpimpin, hanya bedanya di masa Orde Baru, pers dipandang sebagai institusi politik yang harus diatur dan selalu diawasi.

\subsubsection{Pers di era reformasi}

Kalangan pers dapat bernafas lega karena di era ini (setelah reformasi 1998- sekarang) dikeluarkan UU No. 39 tahun 1999 tentang Hak Asasi Manusia dan UU No. 40 tahun 1999 tentang pers. Pada Pasal 4 UU Pers tersebut, dijamin bahwa kemerdekaan pers sebagai hak asasi warga negara. Dalam UU ini juga dijamin tidak ada pembreidelan, penyensoran dan pelarangan penyiaran sebagaimana bunyi Pasal 4 (ayat 2).

Wartawan memiliki hak tolak dalam mempertanggungjawabkan pemberitaan di depan hukum, yaitu wartawan berhak untuk tidak mengungkapkan identitas dan keberadaan narasumber demi keamanan narasumber dan keluarganya. Hak itu dapat digunakan jika wartawan dimintai keterangan pejabat penyidik atau menjadi saksi di pengadilan. Tapi hak tolak tidak berlaku atau dapat dibatalkan demi keamanan, keselamatan negara, atau ketertiban umum yang dinyatakan oleh pengadilan, seperti teroris, pemberontak, penjahat, dan lain-lain Tujuan Hak Tolak adalah agar wartawan dapat melindungi sumber informasi, dengan cara menolak menyebutkan identitas sumber informasi. 


\subsection{Mewujudkan Kebebasan Pers yang bertanggungjawab berdasarkan Pancasila}

Menurut Siebert, Peterson dan Scramm dalam bukunya four theories of the press, terdapat empat macam teori pers yakni pers otoriter, liberal, komunis dan teori pers tanggungjawab sosial. Indonesia tergolong negara penganut teori yang ke empat yaitu teori pers tanggungjawab sosial (social responsibility). Teori ini menegaskan bahwa pers adalah forum sebagai wadah memusyawarahkan berbagai problem dalam rangka tanggungjawab terhadap masyarakat. Dalam teori tanggungjawab sosial juga terdapat esensi pengembangan kebebasan pers. Namun kebebasan pers yang bertanggungjawab tersebut berasaskan pada prinsipprinsip demokrasi, keadilan dan supremasi hokum.

Tantangan terberat saat ini dengan adanya kebebasnan pers adalah datang dari kebebasan pers itu sendiri. Artinya para jurnalis atau perusahaan penerbitan apakah sanggup untuk tidak menodai arti kebebasan itu dengan tidak menerima pemberian atau godaan-godaan material yang berhubungan dengan berita atau publikasi sebuah berita.

Implementasi kebebasan pers memiliki batasan. Yang membatasi adalah kebebasan dari pihak-pihak lain. Pers yang bebas dan mandiri tidak boleh melanggar batas-batas privasi, melanggar hak asasi pribadi pihak lain. Pada negara demokratis, pers perlu memiliki tanggung jawab dalam pemberitaannya. Bertanggung jawab terhadap publik tentang apa yang telah diberitakan. Pers yang memberitakan dapat dituntut oleh pihak publik yang merasa dirugikan oleh pemberitaannya atau karena mempublikasikan berita yang tidak benar. Sering terjadi akibat pemberitaan yang tidak benar dan merugikan mendapat reaksi dan digugat, bahkan didemo oleh masyarakat. Masyarakat berhak melakukan penilaian dan menguji terhadap setiap pemberitaan dari media massa. Sesuai ketentuan perundangan yang berlaku bahwa penyelesaian terhadap 
pers yang bermasalah dilakukan melalui Dewan Pers atau dapat melalui jalur hukum. Kebebasan yang bertanggung jawab dari media massa pada akhirnya bergantung pada independensi dan profesionalisme para pekerja media.

Berkenaan dengan hak asasi berbicara dan memperoleh informasi, negara Indonesia telah menjamin pemenuhan hak-hak tersebut. Namun patut disadari bahwa penyalahgunaan kebebasan oleh media massa akan berdampak pada (1) Timbulnya keguncangan dan ketidakpastian dalam masyarakat, (2) Timbulnya bahaya bagi keselamatan bangsa dan negara yang berpotensi terjadi disintegrasi (3) dapat menimbulkan fitnah dan kegaduhan berbangsa.

Pada hakekatnya kehidupan Pers Indonesia merupakan produk dari sistem nilai dan berlaku dalam masyarakat yang diproyeksikan dalam bidang kegiatan pers. Pers sebagai modal bangsa haruslah menegakkan aturan main (rules of the games) pers nasional, seperti apa yang terkandung dalam falsafah Pancasila, UUD 1945, UU tentang Pers, kode etik jurnalistik, perundangan lain serta tata nilai yang berlaku dalam masyarakat. Memahami pers bukanlah sekedar mengetahui bahwa media sebagai wahana memperoleh informasi, melainkan juga pentingnya pengetahuan publik mengenai berbagai fungsi pers selain fungsi informasi. Pers adalah juga jendela pengetahuan, jendela pertukaran pikiran secara bebas.

Dalam realitas kehidupan pers di tanah air sangat disayangkan ketika media nampak masih terlelap dalam eufouria kebebasan yang pada akhirnya menjadi "kebablasan". Banyak terjadi kasus media yang justru menabrak norma atau aturan yang ada dan hanya berlindung dibalik topeng "demokrasi". Media bukanlah menjadi penyambung suara rakyat, melainkan berubah menjadi seteru masyarakat. Seyogyanya media harus mengedepan- 
kan tanggungjawab moralnya kepada masyarakat dan jangan hanya memikirkan keuntungan ekonomi semata.

Yang sangat membuat prihatin adalah dengan makin banyaknya konten media yang sebenarnya tidak menjawab apa yang dibutuhkan oleh masyarakat samasekali. Berita-berita yang dangkal, sinetron, reality show, iklan, hiburan, komedi dan infotainment menjadi sajian utama media di tanah air setiap harinya. Hal ini semakin diperparah dengan kenyataan bahwa media saat ini sering kali mengekspos kehidupan pribadi para publik figur yang sebenarnya tidak perlu dipublikasikan. Sangat ironi dengan perjuangan keras membangun kebebasan pers, kemudian dalam kenyataannya justru menjadikan kualitas pers Indonesia jauh lebih jelek dari kondisi pers di masa lalu.

Nampaknya sering terjadi perbedaan pemahaman atas makna dibalik "kebebasan pers", sehingga terjadi carut marut dalam penerapan kebebasan pers di Indonesia. Karena itu harus dipahami bersama bahwa pers bukan berarti pekerja pers (jurnalis) dan media dapat semaunya membuat karya jurnalistik. Sebab menurut Fromm (dalam Ashadi Siregar, 2000:46) pada hakekatnya kebebasan pers memiliki dua dimensi, yaitu "bebas dari" dan "bebas untuk". Kedua dimensi ini jelas sangat berbeda sehingga kita perlu untuk memahaminya dengan baik. Pemahaman dimensi "bebas dari", biasa diartikan dalam kaitan dengan kekuasaan. Aspek kekuasaan ini dikelompokkan menjadi dua yakni internal dan ekstermal. Kekuasaan internal adalah kekuasaan yang berasal dari dalam diri media itu sendiri misalnya dari pemilik ataupun redaksi. Sedangkan kekuasaan eksternal meliputi institusi di luar pers seperti negara, ekonomi dan sosial. Jadi konsep bebas dalam dimensi ini berarti bahwa pers seharusnya bebas dari intervensi pihak luar maupun internal media itu sendiri.

Pemahaman mengenai pengertian dimensi "bebas untuk" harus dipahami tidak hanya dikaitkan dengan kebebasan pers untuk 
bertindak bebas tetapi lebih jauh kepada hak masyarakat. Media sebagai institusi masyarakat seharusnya bergerak atas dasar melayani kepentingan masyarakat dalam hal informasi yang benar. Dalam aktualisasinya media meskipun diberi kebebasan, ia tidak boleh lupa akan tanggungjawab moralnya terhadap masyarakat.

Ashadi Siregar dalam sebuah tulisannya berjudul Media Pers dan Negara: Keluar dari Hegemoni, menyatakan bahwa kebebasan pers dalam proses demokrasi pada dasarnya membutuhkan kredibilitas dari elit sosial dan media/pers itu sendiri. Sebab bila tidak demikian maka dimungkinakan proses sosial akan terganggu. Transparansi dari kehidupan publik dan moralitas elit menjadi bagian yang tidak terpisahkan dalam penilaian atas kredibilitas tersebut. Dengan demikian pengawasan media merupakan kegiatan yang tidak terpisahkan untuk menilai kredibilitas media itu sendiri. Barangkali inilah yang kurang dalam implementasi kebebasan pers di tanah air yang berdampak pada banyaknya gangguan yang muncul dalam masyarakat kita. Elite sosial dan media/pers belum cukup kredibel dalam menghadapi kebebasan yang kini tersedia di depan mata (Ashadi Siregar, 2000)

Berkenaan dengan realitas kebebasan pers saat ini kiranya perlu mendapat koreksi dan solusi terhadap implementasi kebebasan pers di Indonesia. Sebab bagaimanapun kebebasan pers yang tanpa batas pada akhirnya hanya akan mencederai publik dan norma maupun aturan yang berlaku dalam masyarakat. Karena itu kita perlu menyikapinya dengan cerdas.

Teori pers tanggungjawab sosial adalah tanggungjawab media atau pers yang berupaya menunjukkan pada suatu konsep tentang kewajiban media untuk mengabdi terhadap kepentingan masyarakat. Oleh karena itu pers tanggungjawab sosial memandang perlu adanya pers dan sistem jurnalistik yang menggunakan dasar moral dan etika. Commision on the freedom of the press, 
mengajukan 5 persyaratan bagi pers yang bertanggungjawab kepada masyarakat, yaitu :

a. Berita yang sehari-hari disajikan haruslah dapat dipercaya, lengkap dan cerdas dalam konteks yang memberikan makna

b. Media harus berfungsi sebagai forum untuk bertukar komentar dan kritik

c. Media harus memproyeksikan gambaran yang benar-benar mewakili dari kelompok konstituen dalam masyarakat

d. Media harus menjelaskan dan menyajikan tujuan dan nilainilai masyarakat

e. Media harus menyiapkan akses penuh terhadap informasiinformasi yang tersembunyi pada suatu saat (Sodikin Ali, 2012: 36)

Mengingat sistem pers Indonesia adalah sistem pers yang melaksanakan tanggungjawab sosial maka seharusnyalah pers di tanah air mengembangkan "self censorship" dalam aktualisasinya. Namun sensor diri dalam hal ini bukanlah dikarenakan kecintaan yang berlebihan terhadap negara seperti yang terjadi di Jepang melainkan sebagai tanggungjawab moral yang harus diberikan kepada masyarakat sebagaimana media adalah penyambung suara rakyat. Dengan demikian, media dalam tindakannya akan senantiasa mengutamakan kepentingan publik dengan mempertimbangkan nilai-nilai yang terkandung dalam Pancasila sebagai ideologi bangsa. Dengan demikian profesionalisme dan kredibilitas harus menjadi prioritas dalam gerak kerja pers di tanah air.

Berangkat dari narasi di atas nampaknya dalam pelaksanaan kebebasan pers di tanah air membutuhkan suatu pengawasan, mengingat tujuan akhir pers adalah untuk menjamin hak warga negara untuk tahu dan juga bebas berekspresi. Pengawasan media ini pada dasarnya adalah untuk mengawasi agar 
media tidak dijadikan sebagai saluran kekuasaan satu pihak, yang pada akhirnya tentu akan mencederai hak rakyat.

Pengawasan dalam hal ini bukan dalam artian membatasi gerak kerja pers, tetapi sebaliknya justru untuk memelihara media pers agar tetap sebagai institusi masyarakat yang bertujuan untuk mewujudkan hak rakyat untuk tahu dan berekspresi. Pengawasan tersebut dapat dilaksanakan dalam 3 tingkatan yakni sebagai berikut:

a. Pengawasan oleh media sendiri. Pengawasan ini dilakukan di lingkungan perusahaan/organisasi media, dengan mengadakan kelembangaan Ombudsman internal yang bekerja secara independen untuk mengawasi kinerja pekerja professional di media yang bersangkutan.

b. Pengawasan oleh Lembaga Profesi. Pengawasan ini dilakukan terhadap pekerja media yang juga tergabung di dalamnya. Lembaga ini mengadakan pengujian atas hasil kerja dan prosedur kerja dari anggota yang menjadi anggota pekerja professional dalam suatu perusahaan media, atas perintaan suatu perusahaan bersangkutan manakala ada complain atau protes masyarakat terhadap hasil kinerja dari pekerja profesionalnnya. Dengan kata lain perusahaan media meminta bantuan lembaga profesi dalam memeriksa pekerjaannya bila dianggap merugikan masyarakat.

c. Pengawasan oleh lembaga dalam masyarakat. Pengawasan ini dilakukan oleh lembaga masyarakat dengan pengamatan terus-menerus terhadap muatan pers/media untuk menjaga hak warga masyarakat. Pengamatan harus dilakukan secara kontiniu, tidak semata karena ada protes dari masyarakat.

Memang sangat disadari untuk menjaga terpenuhinya kepentingan publik dalam implementasi kebebasan pers, bukanlah hal yang mudah, namun upaya yang di sebutkan di atas sepertinya dapat dijadikan sebagai bahan pertimbangan untuk menjawab/ 
solusi dari carut-marut pelaksanaan kebebasan pers di tanah air yang seringkali justru cendrung kebablasan.

Berkenaan dengan kondisi saat ini kiranya sangat penting menggagas kembali atau memformulasi kembali pers yang bertanggungjawab berdasarkan prinsip-prinsip Pancasila. Pers Pancasila sesungguhnya telah didengungkan sejak masa orba, namun tidak pernah dilaksanakan secara nyata dalam kehidupan pers di Indonesia. Prinsip-prinsip pers Pancasila yang perlu dihidupkan kembali sebagaimana dikemukakan oleh Janner Sinaga (1989: 34-35) yaitu sebagai berikut :

a. Menerapkan mekanisme kerja Pers yang menjalin hubungan timbal balik antara pers, pemerintah dan masyarakat

b. Mengembangkan dinamika kehidupan pers berdasarkan paham hidup menghidupi, saling membantu dan bukan saling mematikan

c. Perlu dikembangkan kultur politik dan mekanisme yang memungkinkan berfungsinya sistem kontrol sosial dan kritik yang konstruktif secara efektif. Namun kontrol sosial tersebut haruslah PEMBAHASAN dan caranya tetap tidak terlepas dari asas keselarasan, keseimbangan serta ketertiban untuk saling hidup menghidupi, dan bukan saling mematikan. Kontrol harus yang tetap berpijak pada nilai-nilai sistem pers, termasuk pers yang bebas dan bertanggungjawab.

Dengan demikian Pers Pancasila masih sangat relevan untuk dikembangkan guna dijadikan tolok ukur Pers Indonesia. Menjadi tugas semua komponen bangsa terutama institusi yang terkait dengan pers untuk merumuskan paradigm Pers Pancasila secara konseptual sehingga dapat dijadikan rujukan dalam membangun Pers Indonesia ke depan. 


\section{PENUTUP}

Keberadaan media massa menjadi sarana yang dapat digunakan oleh masyarakat untuk menyampaikan aspirasi dan sekaligus juga sebagai sarana berekspresi. Implementasi kebebasan Pers memang penting dalam suatu negara dengan sistem pemerintahan yang demokratis, mengingat sistem ini menjamin keterlibatan masyarakat secara langsung dalam pelaksanaan pemerintahan. Namun harus tetap disadari bahwa penerapan sistem kebebasan pers yang tanpa batas, maka pada titik tertentu akan mencederai hak-hak rakyat dan justru bias melanggar aturan/ norma yang berlaku dalam masyarakat Indonesia. Karena itu dalam implementasi kebebasan pers perlu diadakan suatu pengawasan. Pengawasan ini bukan ditujukan untuk membatasi ruang gerak/tindakan media, melainkan bertujuan untuk menjaga media agar tetap menjadi sarana perwujudan hak-hak rakyat guna memperoleh informasi dan menyampaikan pendapat.

Budaya sensor diri dalam media tentulah sangat penting untuk dikembangkan mengingat sistem pers kita adalah sistem pers tanggung jawab sosial yang seharusnya menghargai nilai-nilai yang terkandung dalam falsafah bangsa yakni Pancasila. Dengan adanya sensor diri dalam masing-masing media diharapkan media di tanah air dapat bekerja secara professional dalam mengemban tugas menyuarakan suara rakyat. Ke depan gagasan Pers Pancasila kiranya perlu terus dikaji sehingga terlahir sebuah paradigm konseptual yang dapat menjadi acuan dalam pengembangan kebebasan pers yang mengacu kepada nilai-nilai Pancasila. 


\section{DAFTAR PUSTAKA}

Harahap, Krisna. (2000) Kebebasan Pers di Indonesia. Bandung: Grafitri

McQuail, Denis. (2000). McQuail's Mass Communication Theory. Fourth Edition. London, Thousand Oaks, Sage Publications, New Delhi

Nurudin. (2003). Pers dalam Lipatan Keuasaan, Tragedi Pers Tiga Zaman, Malang: UMM Press

(2004). Sistem Komunikasi Indonesia. Jakarta: Rajawali Press

Romli, Komsahrial. (2016). Komunikasi Massa, Jakarta: Grasindo Syahriar, Irman. (2019). Penegakan Hukum Pers, Jakarta: Aswaja Pressindo

Severin, W.J. dan Tankard, Jr, J.W. (2001). Communication Theories: Origins, Methods, and Uses in the Mass Media. Newyork: Longman

Siregar, Ashadi. (2000). Media Pers \& Negara: Keluar dari Hegemoni. I Gusti Ngurah Putra. Pers Indonesia Masa Transisi. Jurnal ISKI. Vol.VI. November 2001. ISSN 08534470

Sinaga,Janner. (1989) Sistem Pers Pancasila, Jakarta : Ultima Undang-undang Nomor. 40 tahun 1999 tentang Pers 


\title{
PENTINGNYA NILAI PANCASILA DALAM KEBIJAKAN IMPOR BERAS
}

\author{
Dicky Marsadi \\ Fakultas Pertanian dan Bisnis, Universitas Dwijendra \\ Dickymarsadi14@gmail.com
}

\section{PENDAhuluan}

Indonesia merupakan negara agraris yang sebagian besar penduduknya bekerja di sektor pertanian. Menurut Badan Pusat Statistik (2020) dari 128,45 juta orang 38,23 juta orang atau sekitar $29,76 \%$ bekerja di sektor pertanian, $19,23 \%$ di sektor perdagangan, $13,61 \%$ di sektor industri pengolahan dan sektor pengadaan listri $\&$ gas sebesar $0,24 \%$. Komoditas pertanian yang dikembangkan di Indonesia antara lain perkebungan, hortikultura dan pangany.

Padi merupakan komoditas tanaman pangan penghasil beras yang memegang peranan penting dalam kehidupan ekonomi Indonesia (Candra, et al., 2017). Beras merupakan bahan makanan pokok yang penting bagi sebagian besar masyarakat Indonesia. Menurut BPS (2015) beras merupakan komoditas yang memberikan kontribusi terbesar pada Garis Kemiskinan, baik di perkotaan maupun perdesaan, karena sebagian besar pengeluaran penduduk miskin digunakan untuk membeli makanan, khususnya beras. Beras sebagai pangan dikonsumsi kurang lebih $90 \%$ dari 
keseluruhan penduduk Indonesia untuk makanan pokok sehari-hari (Saragih, 2001). Kondisi ini merupakan tantangan yang sangat besar dalam pengembangan pertanian padi. Permasalahan yang dihadapai petani padi yang ada di Indonesia saat ini yaitu menurunnya produktivitas lahan, serangan hama dan penyakit tanaman, menurunnya produktivitasnya dari tahun-ketahun karena lahan garapan sawah semakin kecil akibat peralihan lahan pertanian ke industri-industri dan perumahan. Menurut BPS (2015) beras merupakan komoditas yang memberikan kontribusi terbesar pada garis kemiskinan, baik di perkotaan maupun perdesaan, karena sebagian besar pengeluaran penduduk miskin digunakan untuk membeli makanan, khususnya beras.

Selain permasalahan produksi yang dihadapi petani padi di Indonesia. Terkadang kebijakan yang dikeluarkan pemerintah cenderung merugikan petani padi yang ada di Indonesia. Salah satu isu kebijakan yang dianggap merugikan petani adalah kebijakan impor beras diawal tahun 2021 yang dinyatakan oleh Menteri Perdagangan Muhammad Lutfi (Kompas, 2021). Kebijakan ini sering dianggap merugikan petani karena dengan adanya impor beras pada saat panen raya dapat menurunkan harga gabah dan membuat petani susah memasarkan hasil panennya. Walaupun kebijakan ini baru wacana dari menteri perdagangan kebijakan ini telah menimbulkan beberapa dampak negatif di berbagai wilayah salah satunya Tuban dimana nilai jual gabah menurun dan berada dibawah harga pasar yang ditentukan oleh pemerintah. Oleh karena itu kita perlu mengkaji kembali terkait kebijakan impor dan mencarikan solusi terkait permasalahan perberasan yang ada di Indonesia agar sesuai dengan Pancasila demi terwujudnya nilainilai yang ada pada butir-butir Pancasila. 


\section{PEMBAHASAN}

Beras merupakan komoditas pertanian yang memainkan peran penting dalam kelangsungan hidup masyarakat Indonesia. Beras tidak hanya merupakan sumber energi dan protein, tetapi juga sumber vitamin dan mineral yang bermanfaat bagi kesehatan. Pada sistem agribisnis beras berperan dalam Pemantapan ketahanan pangan, 2) Menciptakan lapangan kerja, dan 3) Upaya pengentasan kemiskinan (Suryana dan Kariyasa, 2008). Beras juga memainkan peran penting dalam menjaga stabilitas ekonomi, karena usaha perberasan menjadi sumber penghidupan bagi sebagaian masyarakat Indonesia yang bekerja di sektor pertanian khususnya petani padi.

Beras mempunyai nilai politik strategis, yang mempunyai implikasi, pemerintahan akan stabil jika beras harganya stabil dan mudah diperoleh. Terdapat empat masalah yang berkaitan dengan kondisi pemberasan di Indonesia, pertama rata-rata luas garapan petani rata-rata hanya 0,3 ha, kedua, sekitar $70 \%$ petani padi termasuk golongan masyarakat miskin dan berpendapatan rendah. Ketiga, hampir seluruh petani padi adalah net konsumer beras dan keempat, rata-rata pendapatan dari usaha tani padi hanya sebesar $30 \%$ dari total pendapatan keluarga (Suryana dan Kariyasa 2008).

Untuk meningkatkan pendapatan petani padi pemerintah mengelurkan kebijakan melalui beberapa Instruksi presiden (INPRES) dari tahun 2007 sampai 2015. Instruksi presiden (INPRES) merupakan perintah atasan kepada bawahan yang bersifat individual, konkret, dan sekali-selesai sehingga tidak dapat digolongkan dalam peraturan perundang-undangan atau peraturan kebijakan. Inpres hanya dapat mengikat menteri, kepala lembaga pemerintah non departemen, atau pejabat-pejabat pemerintah yang berkedudukan di bawah presiden dalam melaksanakan penyelenggaraan pemerintah. INPRES yang dikeluarkan membahas beberapa hal terkait harga gabah yakni : Harga Pembelian 
Pemerintah (HPP), Harga Gabah Kering Panen (GKP), dan Harga Gabah Kering Giling (GKG).

1. INPRES 3/2007 dimulai mulai pada 1 April 2007, dimana kebijakan ini menentukan Harga Pembelian Pemerintah (HPP) per Kg Gabah Kering Panen $(\mathrm{GKP})=$ Rp. 2.000 (petani), Rp. 2.035 (penggilingan), Gabah Kering Giling $(\mathrm{GKG})=2.575$.

2. INPRES 1/2008 dimulai 22 April 2008, Harga Pembelian Pemerintah (HPP) per Kg GKP = Rp. 2.200 (petani), Rp. 2.240 (penggilingan), GKG = Rp. 2.800 .

3. INPRES 8/2008 dimulai 1 Januari 2009, Harga Pembelian Pemerintah (HPP) per Kg GKP = Rp. 2.400 (petani), Rp. 2.440 (penggilingan), GKG = Rp. 3.000.

4. INPRES 7/2009 dimulai 1 Januari 2010, Harga Pembelian Pemerintah (HPP) per Kg GKP = Rp. 2.640 (petani), Rp. 2.685, (penggilingan), GKG = Rp. 3.300.

5. INPRES 3/2012 dimulai 27 Februari 2012, Harga Pembelian Pemerintah (HPP) per Kg GKP = Rp. 3.300 (petani), Rp. 3.350 (penggilingan), GKG = Rp. 4.150.

6. INPRES 5/2015 dimulai 17 Maret 2015, Harga Pembelian Pemerintah (HPP) per Kg GKP = Rp. 3.700 (petani), Rp. 3.750 (penggilingan), GKG = Rp. 4.600 .

Pada tahun 2020 pemerintah mengeluarkan kebijakan PERMENDAG 24/2020 yang dimulai pada 19 Maret 2020, dimana Harga Pembelian Pemerintah (HPP) per Kg GKP = Rp. 4.200 (petani), Rp. 4.250 (penggilingan), GKG = Rp. 5.250. Kebijakan harga dasar gabah (HDG) diharapakan berperan positif dalam meningkatkan produksi dan upaya menstabilkan harga gabah (Prijambodo 2001; Saifullah 2001).

Dalam rangka mewujudkan kesejahteraan masyarakat khususnya petani dan keadilan sosial sesuai dengan nilai-nilai Pancasila, Pemerintah Indonesia bersama Dewan Perwakilan Rakyat RI menerbitkan Undang-Undang 18/2012 tentang Pangan 
dan Undang-Undang 19/2013 tentang Perlindungan dan Pemberdayaan Petani. Undang-Undang tersebut menyebutkan peran Negara untuk melindungi petani dan meningkatkan produksi pangan melalui pengaturan impor pangan, termasuk penetapan Bea Masuk.

Penetapan tarif bea masuk impor didasarkan pada Undang-Undang 10/1995 yang diubah dengan Undang-Undang 17/2006 tentang Kepabeanan. Kepabeanan adalah segala sesuatu yang berhubungan dengan pengawasan atas lalu lintas barang yang masuk atau keluar daerah pabean serta pemungutan bea masuk dan bea keluar. Pelaksanaan pemungutan atau penetapan tarif bea masuk diatur oleh Menteri melalui penerbitan Peraturan Menteri Keuangan. Tarif impor atau bea masuk umumnya digunakan pemerintah sebagai pelindung atas sektor/bidang ekonomi tertentu sesuai dengan potensi ekonomi nasional yang akan dikembangkan (Fuad, 2004). Di samping berfungsi untuk mengatur, tarif bea masuk bertujuan sebagai salah satu sumber penerimaan negara (Hardono, et al., 2004)

Ditengah kebijakan yang dikeluarkan pemerintah melalui Undang-Undang 18/2012 tentang Pangan dan Undang-Undang 19/2013 dan PERMENDAG 24/2020 petani padi mengalami dilema terkait adanya isu kebijakan import beras sebanyak 1 juta ton diawal tahun 2021 yang dinyatakan oleh Menteri Perdagangan Muhammad Lutfi (Kompas, 2021). Pemerintah dinilai cenderung pragmatis dalam mengambil kebijakan untuk mengatasi masalah ketahanan beras nasional dengan langsung mengularkan pernyataan terkait impor beras. Kebijakan ini memberikan dapat negatif bagi petani di beberapa daerah seperti Tuban dimana harga gabah di pasaran langsung merosot dimana harga gabah sekarang sebesar Rp 3.700 per $\mathrm{kg}$, yang berada di bawah Harga Pembelian Pemerintah (HPP) yang ditetapkan pemerintah yakni Rp 4.200 (Henry, 2021).

Kepala Dinas Pertanian Kota Mataram, Ir. H. Mutawalli, MM juga menolak kebijakan Menteri Perdagangan yang ingin 
mengimpor beras diawal tahun 2021. Beliau menyebutkan, produksi padi NTB mencapai 2,5 juta ton pertahun (SuaraNTB, 2021). Sedangkan, pemenuhan kebutuhan masyarakat hanya 800 ton. Kepala Dinas Pertanian Kota Mataram khawatir jika impor beras dipaksakan, petani akan kebingungan menjual sisa beras yang ada di NTB. Walaupun belum disahkan kebijakan ini sudah menimbulkan dampak yang bertentangan dengan nilai-nilai Pancasila dimana kebijakan ini tidak mampu mewujudkan keadilan dan kemakmuran sosial bagi bangsa Indonesia dan cenderung menimbulkan dampak negatif bagi petani padi sehingga petani tidak merasakan keadilan dan kemakmuran dari kebijakan yang dibuat.

Kebijakan impor beras yang dilakukan pemerintah sebenarnya bisa dipahami. Pemerintah berupaya memperkuat ketahanan stok beras nasional sekaligus mengantisipasi kurangnya pasokan dan lonjakan harga beras akibat "permainan" spekulan. Kebijakan impor beras memang dapat menstabilkan harga beras dalam waktu relatif singkat namun, guna menjaga menjaga stabilitas harga beras dalam jangka panjang pemerintah perlu memperhatikan kepentingan petani padi dalam rangka peningkatan produksi padi (Widiarsih; 2012, dan Hessie; 2009). Kebijakan impor beras yang akan dilakukan oleh pemerintah kemudian menimbulkan pertanyaan, apakah upaya pemerintah selama ini untuk mewujudkan swasembada pangan ? Dengan kebijakan impor beras maka menunjukkan bahwa upaya pemerintah untuk dapat mewujudkan swasembada pangan belum ada hasilnya dan masih jauh dari harapan. Untuk menjawab pertanyaan dan menyelesaikan permasalah yang ada, pemerintah Indonesia perlu membuat kebijakan-kebijakan yang didasari oleh nilai-nilai Pancasia sehingga ke depan yang mampu menciptakan keadilan, kemakmuran dan kesejahteraan kepada masyarakat Indonesia khususnya petani padi. 
Pembatasan impor beras oleh pemerintah dengan cara peningkatan bea masuk beras sehingga meningkatkan harga beras impor. Peningkatan harga tersebut menyebabkan konsumen beralih untuk mengkonsumsi beras lokal yang harganya relatif lebih murah dan permintaan beras impor menjadi menurun. Banyaknya permintaan konsumsi beras lokal mendorong produsen (petani) untuk meningkatkan produksi beras. Keputusan Pemerintah untuk meningkatkan Bea masuk beras mampu meningkatkan surplus produsen yang nantinya memberikan insentif bagi petani untuk meningkatkan produksinya dan kesejahteraan produsen semakin meningkat (Widyawati, et al., 2014). Peningkatan bea masuk akan memberikan penerimaan kepada pemerintah dan meningkatkan surplus atau keuntungan produsen. Mengingat bea masuk merupakan pajak tidak langsung, beban tarif impor atau bea masuk akan ditransfer ke produk, mendorong kenaikan harga produk, sehingga mengurangi surplus atau keuntungan konsumen dan kesejahteraan secara umum (Hardono, et al., 2004). Menurut Febriyanti (2012) Efek pengenaan bea masuk terdiri atas :

1. Efek harga, meningkatnya mata uang nasional sebesar harga impor yang dikenakan.

2. Efek konsumsi, permintaan di pasar dalam negeri terhadap barang impor menurun karena efek harga. Besarnya konsumsi yang berkurang tergantung pada besarnya elastisitas harga dari permintaan. Jika barang impor adalah barang kebutuhan pokok, maka elastisitasnya mendekati nol yang artinya efek harga terhadap konsumsi kecil.

3. Efek proteksi atau produksi, produksi di dalam negeri naik akibat efek harga. Karena harga barang impor lebih mahal daripada harga barang yang sama buatan dalam negeri, permintaan domestik terhadap barang buatan sendiri pun meningkat sedangkan terhadap barang impor menurun. 
4. Efek pendapatan, hasil pajak impor merupakan pendapatan bagi pemerintah.

5. Efek redistribusi, harga barang impor naik akibat bea masuk yang tinggi sehingga menyebabkan kerugian bagi konsumen karena berkurangnya consumer surplus. Namun, kenaikan harga barang tersebut dinikmati oleh produsen (producer surplus) sebagai akibat dari perpindahan surplus dari konsumen kepada produsen

Pemerintah harus memprioritaskan penyerapan beras produksi dalam negeri terlebih dahulu sebelum melakukan penugasan dari pemerintah untuk mengimpor satu juta ton beras pada tahun ini. Selain itu pemerintah perlu mengkaji ulang mengenai kebijakan impor beras. Salah satunya adalah waktu. Ketika ingin mengimpor beras pemerintah harusnya tidak menentukan kapan masa panen raya. Kebijakan yang direncanakan oleh Kementerian Perdagangan untuk impor beras diawal tahun menjadi pertentangan karena pada masa tersebut memasuki panen raya dibeberapa wilayah dan dirasa terlalu cepa untuk mengetahui apakah produksi beras nasional dapat memenuhi kebutuhan stok beras atau tidak. Untuk mengatasi permaslahan yang ada disini perlukannya Pancasila sebagai Ideologi Negara dalam membuat suatu kebijakan-kebijakan agar kebijakan yang dibuat mampu mewujudkan masyarakat adil dan makmur yang merata material dan spiritual.

\section{KESIMPULAN}

Berdasarkan pada kajian yang telah dilakukan dapat disimpulkan bahwa kebijakan impor beras yang di sampaikan oleh Menteri perdagangan Muhammad Lutfi diawal tahun 2021 memberikan dampak negatif bagi petani dimana sebagian wilayah 
mengalami penurunan harga gabah bahkan dibawah harga dasar yang ditentunkan oleh pemerintah.

Salah satu upaya yang dapat dilakukan untuk mengurangi dampak negatif yang ditimbulkan dari kebijakan impor beras yakni meningkatkan bea masuk beras ke Indonesia sehingga meningkatkan harga beras impor. Peningkatan harga tersebut menyebabkan konsumen beralih untuk mengkonsumsi beras lokal sehingga mampu mendukung kesejahteraan dan kemakmuran khususnya petani padi yang ada di Indonesia.

Pemerintah harus mengkaji ulang terkait kebijakan impor beras. Salah satunya adalah waktu. Pernyatan yang dikeluarkan Menteri perdagangan diawal tahun 2021 dianggap tidak tepat, karena diputuskan pada awal tahun. Padahal, pada masa tersebut belum dapat diketahui apakah produksi beras nasional dapat memenuhi kebutuhan stok beras atau tidak. Selain itu, pada awal tahun dibeberapa wilayah sedang memasuki panen raya. Sebaiknya pemerintah menunggu sampai musim panen berakhir atau di pertengahan tahun sebelum memutuskan akan melakukan impor atau tidak, dengan berdasarkan indikator-indikator yang mulai tampak.

Dalam mengambil kebijakan pemerintah diharapkan mampu menerapkan nila-nilai Pancasila agar setiap keijakan atau Tindakan yang diambil mampu memberikan dampak positif bagi seluruh rakyat Indonenisa khususnya bagi petani padi.

\section{DAFTAR PUSTAKA}

Badan Pengawas Statistik. 2015. Laporan Bulanan Data Sosial

Ekonomi (Edisi 58). Jakarta: Badan Pusat Statistik.

Badan Pengawas Statistik (BPS). 2020. KETENAGAKERJAAN. https://www.bps.go.id/searchengine/result.html. Diakses April 2021

Candra.V.D., M. L. Iskandar., dan M. Usman. 2017. Pertumbuhan dan Hasil Tanaman Padi (Oryza satival) Pada Berbagai 
Pola Jajar Legowo dan Jarak Tanam. J. Agroland 24(1) : 27-35.

Fuad, N. 2004. Dasar-dasar Keuangan Publik. Jakarta: BPPK Departemen Keuangan.

Hardono, Gatoet S., Handewi P. S. Rachman, dan Sri H. Suhartini. (2004). Forum Penelitian Agro Ekonomi, Volume 22 No. 2, 75-88.

Henry. 2021. Serikat Petani Indonesia sebut rencana impor beras abaikan kondisi petani

https://nasional.kontan.co.id/news/serikat-petaniindonesia-sebut-rencana-impor-beras-abaikan-kondisipetani. Diakses April 2021

Hessie, R. (2009). Analisis Produksi dan Konsumsi Beras Dalam Negeri serta Implikasinya Terhadap Swasembada Beras di Indonesia (Skripsi Institut Pertanian Bogor).

Kompas.com.2021.Indonesia Negara Agraris Selalu Impor Beras.

https://www.kompas.com/tren/read/2021/03/27/20030026 5/indonesia-negara-agraris-yang-selalu-impor-berasmengapa-?page=all. Diakses 2021.

Malian, A., H.S. Mardianto., dan M. Ariani. (2004). Faktor-faktor yang Mempengaruhi Produksi, Konsumsi, dan Harga Beras serta Inflasi Bahan Makanan. Jurnal Agro Ekonomi, Volume 22 No. 2, 119-146.

Prijambodo, B. 2001. Kondisi ekonomi makro dan

keuanganpemerintah dalam kebijakan beras nasional. hlm.111-121. Dalam A. Suryana dan S. Mardianto. Bunga Rampai EkonomiBeras. LPEM-Fakultas Ekonomi

Universitas Indonesia, Jakarta.

Saragih, B. 2001. Keynote Address Ministers of Agriculture Government of Indonesia. 2ndNational Workshop On Strengthening The Development And Use Of Hibrid Rice In Indonesia. 1:10 
Saifullah. A. 2001. Peran Bulog dalam kebijakan perberasan nasional. hlm. 83-101.Dalam A. Suryana dan S. Mardianto.Bunga Rampai Ekonomi Beras. LPEMFakultas Ekonomi Universitas Indonesia, Jakarta.

Surya, T.A. 2021. Polemik Kebijakan Impor Berastahun 2021. Pusat Penelitian Badan Keahlian DPR RI. Vol. Xiii, No.6/Ii/Puslit/Maret/2021

Suryana,A. dan Ketut Kariyasa. (2008). Ekonomi Padi di Asia: Suatu Tinjauan Berbasis Kajian Komparatif. Jurnal Forum Penelitian Agro Ekonomi, Volume 26 No. 1, 1731.

Widiarsih, D. (2012). Pengaruh Sektor Komoditi Beras Terhadap Inflasi Bahan Makanan. Jurnal Sosial Ekonomi Pembangunan, Tahun II, No. 6, 244-256. 


\title{
PENDIDIKAN KARAKTER DAN MILAI - NILAI PANCASILA MELALUI CERITA RAKYAT PADA ANAK USIA DINI
}

\author{
I Putu Yudi Sudarmawan \\ Fakultas Keguruan dan Ilmu Pendidikan Universitas Dwijendra \\ sudarmawan@undwi.ac.id
}

\section{PENDAHULUAN}

Kata karakter sudah tidak asing bagi siapapun yang mendengarnya. Dalam kehidupan sehari-hari sangat sering disebut, baik ketika melihat seseorang berperilaku baik maupun berperilaku buruk. Sudaryanti (2012) dalam Kamus Besar Bahasa Indonesia "karakter" diartikan sebagai sifat-sifat kejiwaan, akhlak, atau budi

pekerti. Karakter juga dapat diartikan sebagai tabiat, yaitu perangai atau perbuatan yang selalu di lakukan atau kebiasaan. Dalam Slamet Suyanto (2012) karakter diartikan sebagai nilai-nilai, sikap, dan perilaku yang dapat diterima oleh masyarakat luas, seperti etis, demokratis, hormat, bertanggung jawab, dapat dipercaya, adil dan fair, serta peduli, yang bersumber dari nilai-nilai kemasyarakatan, ideologi negara, dan kewarganegaraan, nilai-nilai budaya bangsa, agama, dan etnik yang diterima oleh masyarakat Indonesia secara luas sehingga tidak menimbulkan konlfik. Darmiyati Zuchdi, dkk. 
(2015) menjelaskan secara praktis, pendidikan karakter adalah suatu sistem penanaman nilai-nilai perilaku (karakter) kepada warga sekolah yang meliputi komponen pengetahuan, kesadaran atau kemauan, dan tindakan untuk melaksanakan nilai-nilai tersebut, baik terhadap Tuhan Yang Maha Esa, diri sendiri, sesama, lingkungan, maupun kebangsaan, sehingga menjadi manusia paripurna. Oleh karena itu karakter sebagai nilai-nilai yang dapat diterima oleh masyarakat membutuhkan sistem penanaman agar melekat pada diri manusia sehingga dapat berperilaku terpuji.

Menurut zulham (2010) ada 5 karakter yang harus di kembangkan yaitu: 1) trustworthy: meliputi jujur, menepati janji, memiliki loyalitas tinggi, integritas pribadi (komitmen, disiplin, selalu ingin berprestasi), 2) menghormati orang lain: perilaku untuk mementingkan kepentingan umum di atas kepentingan pribadi, siap dengan perbedaan dan tidak merasa paling benar, 3) bertanggung jawab: merupakan gabungan dari perilaku yang dapat di pertanggung jawabkannya, segala hal yang dilakukan harus berani menanggung akibatnya, berpikir sebelum bertindak, 4) adil yang meliputi: sikap terbuka, tidak memihak, mau mendengarkan orang lain dan memiliki empati, 5) cinta dan perhatian yang meliputi: menunjukkan perilaku kebaikan, hidup dengan nilai-nilai kebenaran, berbagi kebahagiaan, bersedia menolong orang lain, tidak egois, tidak kasar dan sensitf terhadap perasaan orang lain.

Indonesia lahir dengan Pancasila sebagai ideologi dan dasar negara. Pancasila sebagai sumber hukum. Bagi bangsa Indonesia, Pancasila memiliki nilai-nilai dasar bersifat universal dan tetap. Nilai-nilai itu tersusun secara hierarkis dan pyramidal, mengandung kualitas tertentu yang harus dicapai bangsa Indonesia dan diwujudkan dalam kehidupan bermasyarakat (Rahayu, 2014). Sebagai bangsa Indonesia dan sebagai warga negara yang baik, semestinya menerapkan serta mengamalkan nilai-nilai yang terkandung dalam Pancasila dalam kehidupan 
sehari-hari. Pancasila adalah lima dasar atau lima azas yang diberlakukan di negara Indonesia, dengan sila-silanya berbunyi: Ketuhanan yang Maha Esa, Kemanusiaan yang adil dan beradab, Persatuan Indonesia, Kerakyatan yang dipimpin oleh hikmat kebijaksanaan dalam permusyawaratan perwakilan, Keadilan sosial bagi seluruh rakyat Indonesia.

Seperti yang kita semua ketahui bahwa anak usia dini membutuhkan bimbingan dari orang dewasa, baik guru maupun orang tua. Keberadaan anak usia dini sangat krusial, karena masing-masing individu akan mengalami masa tersebut sekali seumur hidup. Usia dini merupakan fase kehidupan dimana individu mengalami peningkatan secara signifikan dalam perkembangannya. Perkembangan usia dini meliputi berbagai aspek perkembangan, yaitu: nilai agama dan moral, sosial emosional, kognitif, bahasa, fisik motorik, dan seni. Dalam Kurikulum Pendidikan Anak Usia Dini Tahun 2013 terdapat empat kompetensi inti yang distimulasi dalam aktivitas main anak, dua diantarannya adalah sikap dan sosial. Sikap berkaitan dengan perilaku yang ditunjukkan individu dalam menghadapi suatu keadaan. Sosial berhubungan dengan dengan perilaku yang tampilkan individu saat berinteraksi dengan orang lain, baik dengan individu sebaya, individu yang lebih kecil, maupun individu yang lebih dewasa. Sikap dan sosial yang ditunjukkan oleh anak tentunya harus sesuai dengan nilai atau perilaku yang sesuai dengan kondisi masyarakat, dengan kata lain sikap dan sosial tersebut dapat diterima oleh lingkungan. Agar anak mampu menunjukkan sikap dan sosial yang dapat diterima masyarakat, maka diperlukan Pendidikan karakter sejak usia dini. Pendidikan karakter yang ditanamkan pada anak sejak usia dini, tidak dapat dilaksanakan oleh guru di lembaga pendidikan anak usia dini saja, tetapi orang tua sebagai model utama bagi anak juga harus 
memberikan andil dengan porsi yang lebih banyak dari peran guru (Santika, 2019).

Pendidikan anak usia dini adalah pendidikan yang diberikan kepada anak usia di bawah tujuh tahun. Di Indonesia kategori anak usia dini adalah anak berusia 0 tahun hingga 6 tahun. Anak usia dini lahir ke dunia dengan membawa segenap potensi (kecerdasan) yang dianugerahkan Tuhan, namun potensi-potensi tersebut tidak akan berkembang dan muncul secara optimal pada diri anak jika tidak distimulasi sejak usia dini. Sudaryanti (2012: 3) mengungkapkan anak usia dini merupakan masa keemasan (golden age) yang hanya terjadi satu kali dalam masa perkembangan kehidupan, sekaligus masa yang kritis bagi kehidupan anak. Penelitian menunjukkan bahwa sejak lahir anak memiliki 1000 milyar sel otak, sel ini harus dirangsang dan didayagunakan agar terus hidup dan berkembang dan jika tidak dirangsang, sel ini akan mengalami penerunan dan berdampak pada pengikisan segena potensi yang dimiliki anak.

Cerita rakyat yang berkembang di masyarakat pada suatu daerah memiliki nilai pendidikan yang tinggi karena berisikan nasihat-nasihat yang dikemukakan oleh para leluhur secara lisan dan turun-temurun. Nasihat dan nilai-nilai pendidikan tersebut dapat langsung dihayati oleh penikmatnya karena memang dikemukakan secara langsung maupun secara tidak langsung. Nilainilai pendidikan di dalam cerita rakyat sering dikemukakan dengan bahasa figuratif dan juga melalui perumpamaanperumpamaan, oleh karena itu penikmat dituntut menafsirkannya. Mengkaji nilainilai yang terkandung dalam cerita rakyat adalah penting karena memiliki fungsi kultural. Lahirnya suatu cerita rakyat bukan semata-mata didorong oleh keinginan penutur untuk menghibur masyarakatnya, melainkan dengan penuh kesabaran ia ingin menyampaikan nilai-nilai luhur kepada generasi penerusnya. Hal ini sejalan dengan pendapat yang dikemukakan oleh Djamaris 
(2018) yang mengatakan bahwa cerita rakyat adalah golongan cerita yang hidup dan berkembang secara turun temurun dari satu generasi ke generasi berikutnya. Disebut cerita rakyat karena cerita ini hidup di kalangan rakyat dan hampir semua lapisan masyarakat mengenal cerita itu. Cerita rakyat milik masyarakat bukan milik seseorang. Cerita rakyat biasanya disampaikan secara lisan oleh tukang cerita yang hafal alur ceritanya. Itulah sebabnya cerita rakyat disebut sastra lisan.

Cerita rakyat mempunyai ciri-ciri disampaikan secara lisan dan secara turun-temurun, tidak diketahui pembuatnya (anonim), kaya nilai-nilai luhur, bersifat tradisional, memiliki banyak versi dan variasi, mempunyai bentuk - bentuk klise dalam susunan atau cara pengungkapannya. Dilihat dari fungsinya, cerita rakyat berfungsi sebagai hiburan, sebagai sarana pendidikan, sebagai sarana penggalang rasa kesetiakawanan di antara warga masyarakat, sebagai pengokoh nilai-nilai sosial budaya yang berlaku dalam masyarakat, terkadang ajaran-ajaran etika dan moral bisa dipakai sebagai pedoman bagi masyarakat, di dalamnya juga terdapat larangan dan pantangan yang perlu dihindari. dan bisa menjadi tuntunan tingkah laku dalam pergaulan sosial (https://www.dosenpendidikan.co.id/cerita-rakyat/ diakses pada tanggal 26 Juli 2019).

Dengan demikian, Pendidikan karakter untuk anak usia dini adalah hal yang sangat penting dewasa ini, mengingat gencarnya gempuran pengaruh - pengaruh negatif dari kemajuan teknologi yang tentu saja tidak bisa dibendung. Pendidikan karakter itu sendiri lah yang akan menjadi nahkoda dari besarnya gelombang pasang dampak negatif yang akan sangat berbahaya bagi masa depan anak anak kita. Pendidikan karakter harus dikemas dengan baik, menarik, menyenangkan dan tentunya bermanfaat dalam proses pembelajaran. Cerita rakyat adalah metode pembelajaran yang menyenangkan untuk anak - anak yang 
mengandung nilai - nilai karakter dan juga nilai - nilai Pancasila yang sangat mendidik. Harapan kedepannya adalah anak - anak mendapat pengetahuan dan juga tumbuh menjadi pribadi yang berbudaya, berkarakter, dan mampu menerapkan nilai - nilai Pancasila dalam seluruh aspek kehidupan nya.

\section{II.PEMBAHASAN}

Pendidikan karakter adalah suatu sistem penanaman nilainilai perilaku (karakter) kepada warga sekolah yang meliputi komponen pengetahuan, kesadaran atau kemauan, dan tindakan untuk melaksanakan nilai-nilai tersebut, baik terhadap Tuhan Yang Maha Esa, diri sendiri, sesama, lingkungan, maupun kebangsaan, sehingga menjadi manusia paripurna. Oleh karena itu karakter sebagai nilai-nilai yang dapat diterima oleh masyarakat membutuhkan sistem penanaman agar melekat pada diri manusia sehingga dapat berperilaku terpuji. Asmaun Sahlan (2013) Tujuan pendidikan karakter merupakan arah dalam pelaksanaan pendidikan di sebuah lembaga. pendidikan karakter sangat urgen dalam kehidupan manusia khususnya kader-kader muda penerus bangsa Indonesia yang sekarang ini ditempuh dengan dekadensi moral di berbagai lembaga, termasuk dalam dunia pendidikan.

Asmani (dalam Ary Kristiyani, 2014) dalam nilai-nilai karakter dapat dikelompokkan menjadi lima nilai utama.

1. Nilai karakter dalam hubungannya dengan Tuhan, yaitu: pikiran, perkataan, dan tindakan seseorang diupayakan selalu berdasarkan pada nilai-nilai ketuhanan atau ajaran agama.

2. Nilai karakter dalam hubungannya dengan diri sendiri, seperti: jujur, bertanggung jawab, bergaya hidup sehat, disiplin, kerja keras, percaya diri, berjiwa wirausaha, berpikir logis, mandiri. 
3. Nilai karakter hubungannya dengan sesama, yaitu sadar akan hak dan kewajiban diri dan orang lain, mematuhi aturanaturan sosial, mampu berempati dan simpati kepada orang lain.

4. Nilai karakter hubungannya dengan lingkungan, yaitu berkaitan dengan kepedulian terhadap sosial dan lingkunganm seperti menjaga lingkungan dan tidak berbuat kerusakan.

5. Nilai kebangsaan, yaitu berhubungan dengan menempatkan kepentingan bangsa dan negara di atas kepentingan diri dan kelompok. Nilai karakter berupa nasionalis dan menghargai keberagaman.

Nuraeni (2014) menjelaskan nilai-nilai karakter pada anak usia dini, yaitu:

\section{Kejujuran}

Kejujuran adalah salah satu karakter yang harus dimiliki oleh individu, karena kejujuran akan mempengaruhi hubungannya dengan individu lain. Semakin jujur seseorang, maka akan semakin disenangi oleh orang lain dan lingkungannya. Namun sebaliknya, lingkungan tidak akan menyukai orang yang bersikap tidak jujur dan suka berbuat curang. Sikap jujur perlu ditanamkan pada anak sejak dini, melalui ucapan dan tindakan yang dicontohkan oleh orang dewasa, baik guru maupun orang tua, yang dilaksanakan secara terus-menerus. Hasil penanaman sikap kejujuran tidak nampak dalam waktu singkat, namun membutuhkan proses yang cukup panjang sehingga dapat menghasilkan anak berwatak jujur. Oleh karena itu pendidikan karakter harus dilakukan sejak usia dini, sehingga ketika dewasa, anak menjadi generasi yang berkarakter. 


\section{Kedisiplinan}

Disiplin merupakan salah satu perilaku yang penting dan harus dimiliki oleh seseorangapabila menginginkan kehidupan yang baik. Sikap disiplin akan membantu sesoranguntuk mengatur segala hal yang akan dilakukan dalam hidupnya. Segala sesuatu telah direncanakan dan dilaksanakan tepat pada waktunya, sehingga hasil yang diperoleh lebihbaik dan mematuhi aturan. Sikap disiplin yang dimiliki oleh seseorang tidak terbentuksecara langsung. Setiap individu membutuhkan proses agar menjadi pribadi yang disiplinKedisiplinan dapat dibina pada anak sejak usia dini. Pembinaan sikap disiplin tidak dapatdilakukan hanya sekali atau sementara saja. Pembinaan sikap disiplin harus dilaksanakansecara terusmenerus sejak usia dini. Kedisiplinan dapat ditanamkan pada anak melaluipelaksanaan aturan-aturan sederhana, perilaku guru yang selalu on time, maupuntindakan lainnya yang menunjukkan bahwa guru tidak mengulur-ulur suatu aktivitas.

3. Toleransi.

Toleransi adalah sikap peduli kepada orang lain, memberikan kesempatan kepada orang lain untuk mengembangkan diri, dan bentuk-bentuk kepedulian lainnya yang berhubungan dengan kemanusiaan. Sikap toleransi akan tumbuh jika anak tumbuh di lingkungan yang menanamkan toleransi kepada masyarakatnya. Oleh karena itu, anak juga membutuhkan model atau contoh yang akan ditiru agar dapat mengembangkan sikap toleransi.

4. Kemandirian

Kemandirian merupakan sikap yang sangat diperlukan oleh individu. Kemandirian dapatmembantu seseorang untuk mengembangkan diri atas inisiatif sendiri. Sikap mandiri yangdimiliki seseorang dapat mengurangi ketergantungan 
terhadap orang lain. Sikap mandirpada individu harus ditanamkan sejak usia dini melalui berbagai aktivitas anak, baik saatberada di rumah maupun di lembaga pendidikan anak usia dini.

Sementara itu, pembentukan karakter (character building) dapat di lakukan melalui pendidikan budi pekerti yaitu melibatkan aspek pengetahuan (cognitif), perasaan (feeling), dan tindakan (action). Abdullah Nashih Ulwan (dalam Ahmad Atabik dan Ahmad Burhanuddin, 2015) mengemukakan empat metode pendidikan, yaitu:

i. Pendidikan dengan keteladanan

Orang tua yang telah memberikan keteladanan yang baik kepada anak, tidak boleh merasa sudah menunaikan segala tanggung jawab pendidikan anaknya. Artinya keteladanan diberikan secara terus-menerus sehingga keteladanan tersebut dapat membentuk karakter anak.

ii. Pendidikan dengan kebiasaan (pengulangan)

Dalam mendidik anak usia dini, seorang pendidik baik orang tua maupun guru, dapat meminta seorang anak kecil (anak usia dini) untuk mengulang apa yang telah dia dapatkan dari pendidik berupa praktik yang telah dilakukan bersama mereka sebelumnya.

iii. Pendidikan dan nasihat

Pendidikan dan nasihat dapat diberikan melalui kegiatan bercerita. Metode cerita (kisah) ini sangat efektif dalam mendidik anak usia dini, sebab mereka memiliki tingkat penasaran tinggi, sehingga ketika mereka mendengar sesuatu yang baru, maka mereka akan memperhatikan dengan seksama apa yang dikisahkan oleh pendidik, dalam hal ini guru atau orang tua. Di akhir cerita seorang pendidik dapat menunjukkan hikmah di balik kisah yang baru saja 
diceritakan. Sehingga sejak dini mereka telah mendapatkan nilai-nilai pendidikan.

iv. Pendidikan dengan memberikan perhatian dan pengawasan

Perhatian kepada anak dan mengontrol yang dilakukan oleh pendidik adalah asas pendidikan yang utama. Jika melihat sesuatu yang baik, dihormati, maka sang anak terus didorong untuk melakukannya. Jika melihat sesuatu yang jahat, maka harus dicegah, diberi peringatan dan dijelaskan akibatnya.

Berkenaan dengan pembahasan diatas, nilai-nilai dan Pendidikan karakter banyak dibicarakan dalam cerita rakyat. Itu sebabnya, cerita rakyat sarat dengan muatan pendidikan karakter, yang disampaikan dengan ringan dan mudah dicerna. Cerita rakyat mempunyai ciri-ciri disampaikan secara lisan dan secara turun-temurun, tidak diketahui pembuatnya, kaya nilai-nilai luhur, bersifat tradisional, memiliki banyak versi dan variasi, mempunyai bentuk- bentuk klise dalam susunan atau cara pengungkapannya. Dilihat dari fungsinya, cerita rakyat berfungsi sebagai hiburan, sebagai sarana pendidikan, sebagai sarana penggalang rasa kesetiakawanan di antara warga masyarakat, sebagai pengokoh nilai-nilai sosial budaya yang berlaku dalam masyarakat. Ajaran-ajaran etika dan moral yang terkandung dalam cerita bisa dipakai sebagai pedoman bagi masyarakat. Di dalam cerita juga terdapat larangan dan pantangan yang perlu dihindari. Dan bisa menjadi tuntunan tingkah laku dalam pergaulan sosial.

Cerita rakyat merupakan cerita yang berbentuk verbal yang dituturkan oleh masyarakat yang memiliki pengetahuan tentang cerita tersebut. Pada awalnya tuturan cerita ini sering disampaikan antarsesama masyarakat baik pada tataran anak maupun orang dewasa. Cerita ini pula terkadang menjadi dongeng sebelum tidur dan menjadi salah satu prantara orang tua dalam mendidik anak-anaknya. Kebiasaan para orang tua menceritakan cerita pada anak-anak mereka, memberikan kesan yang sangat 
positif pada zamannya. Mereka selalu mengetahui tentang bagaimana menjalin hubungan sosial di tengah masayarakat.

Sebenarnya, cerita rakyat tersebut sangat kental dengan beragam pesan positif tentang kehidupan. Pesan inilah yang belum bisa disadari baik oleh para guru, orang tua, siswa, maupun masyarakat umum. Untuk itulah, diperlukan usaha secara sadar untuk menggali Kembali berbagai pesan-pesan positif tersebut melalui aspek nilai-nilai pendidikan karakter dalam cerita tersebut. Pendidikan karakter merupakan landasan pendidikan yang sebenarnya. Dalam dimensi/komponen ini di deskripsikan sejumlah nilai yang menjadi penanda aktualisasi pendidikan karakter. Nilainilai pendidikan karakter itu meliputi kepercayaan, rasa hormat, tanggung jawab, adil, peduli, kewarganegaraan, belajar sepanjang hayat dan berpikir kritis, serta rajin dan cakap. Kesemua nilai-nilai menjadi acuan dalam mengetahui kandungan pendidikan karakter yang terdapat dalam cerita rakyat. Cerminan nilai-nilai pendidikan karakter dalam cerita rakyat tersebut sangat transparan. Pembaca tentunya harus dapat menelaah beragam unsur-unsur pembangun cerita, baik unsur intrinsik dan ekstrinsik. Pemahamn terhadap unsur-unsur tersebut memberikan kemudahan dalam menelaah lebih intensif tentang keberadaan nilai-nilai pendidikan karakter dan nilai - nilai Pancasila dalam cerita rakyat.

Proses pembelajaran dengan membahas karya sastra berupa cerita daerah memberi kesan positif yang sangat bagus untuk membentuk karakter anak didik. Cerita yang sarat makna dan pesan moral serta sangat menghibur akan memberi suasana menyenangkan dalam belajar. Cerita yang selalu menyajikan kebaikan akan selalu menang melawan kejahatan dan juga hasil dari sifat baik dan buruk yang dimainkan oleh masing - masing karakter merupakan nilai - nilai yang bisa disajikan oleh cerita rakyat kepada peserta didik. Disamping itu, nilai - nilai Pancasila 
yang tercermin dalam sila satu sampai lima pun tersaji lengkap dan mendalam pada cerita rakyat.

Beberapa contoh cerita rakyat yang mengandung Pendidikan karakter dan nilai - nilai Pancasila adalah I Siap Selem, I Tuung Kuning, Pan Balang Tamak, Putri Ayu Dari Bali, Kesuna dan Bawang, Kebo Iwa, Asal Mula Sleat Bali, Danau Batur, dan masih banyak lagi.

\section{PENUTUP}

Pendidikan karakter dimulai sejak usia dini, karena usia dini adalah masa yang kritis dalam perkembangan individu. Pendidikan karakter anak tidak hanya dilaksanakan oleh guru, tetapi orang tua juga memiliki tugas utama untuk melaksanakan pendidikan karakter anak di rumah. Dalam pelaksanaan pendidikan karakter, orang tua dan guru adalah model yang akan ditiru dan diteladani. Anak akan meniru tingkah laku maupun ucapan model tersebut. Oleh karena itu, orang tua dan guru perlu berhati-hati dalam berucap maupun bertingkah laku. Pendidikan karakter anak usia dini melibatkan penanaman sikap terpuji yang sesuai dengan ajaran agama, sikap nasionalisme, masyarakat dan lingkungan sekitar anak, dan sikap terpuji untuk kemaslahatan kehidupan anak itu sendiri. Penanaman sikap terpuji tidak bisa dilaksanakan dalam waktu singkat, dibutuhkan adanya kontinuitas melalui pembiasaan, keteladanan, pemberian nasihat, dan penguatan pada anak sejak dini setiap kali menunjukkan perilaku atau sikap-sikap terpuji.

Dengan pemahaman yang baik tentang berlimpahnya nilai - nilai Pendidikan karakter dan juga nilai - nilai Pancasila yang tersirat maupun tersurat dalam warisan leluhur kita, karya sastra yang tersaji dalam cerita rakyat, hendaknya para guru, siswa dan masyarakat memperbanyak membaca karya sastra. Salah satunya 
adalah cerita daerah. Setiap cerita dareah pasti memiliki nilai pendidikan yang di sampaikan oleh pengarang kepada pembaca. Guru yang bertugas sebagai pendidik menganjurkan siswa untuk banyak-banyak membaca cerita daerah dan menggali nilai pendidikan karakter yang terdapat pada cerita rakyat sasak. Nilai pendidikan tersebut dapat diimplementasikan dalam kehidupannya, sehingga membentuk sikap positif dan betanggung jawab pada tugasnya sebagai pelajar.

\section{DAFTAR PUSTAKA}

https://www.dosenpendidikan.co.id/cerita-rakyat/ diakses pada tanggal 26 Juli 2019

Ahmad Atabik dan Ahmad Burhanuddin. 2015. Konsep Nasih Ulwan Tentang Pendidikan Anak. Elementary Vol. 3 No. 2 Juli-Desember 2015.

Ary Kristiyani. 2014. Implementasi Pendidikan Karakter Pada Pembelajaran Bahasa Di PG-TPA Alam Uswatun Khasanah Sleman Yogyakarta. Jurnal Pendidikan Karakter, Tahun IV, Nomor 3 Oktober 2014.

Asmaun Sahlan. 2013. Pendidikan Karakter dalam Perspektif Islam (Kajian PenerapanPendidikan Karakter di Lembaga Pendidikan Islam). Jurnal el-Hikmah Fakultas TarbiyahUIN Malang hal. 139-149.

Danandjaja dalam https://ekazai.wordpress. com / 2013 / 03 / 08 / 110 / diakses 9 Nopember 2019

Darmiyati Zuchdi, dkk. 2015. Pendidikan Karakter Konsep Dasar dan Implementasi di Perguruan Tinggi. Yogyakarta: UNY Press.

Nuraeni. 2014. Pendidikan Karakter Pada Anak Usia Dini. Jurnal Paedagogy Volume 1 Nomor 2 Edisi Oktober 2014.

Rahayu, Derita Prapti. 2014. Budaya Hukum Pancasila. Yogyakarta: Thofa Media 
Sudaryanti. 2012. Pentingnya Pendidikan Karakter Sejak Usia Dini Dalam Mewujudkan Warga Negara Yang Baik. Makalah dipresentasikan dalam Pengabdian Masyarakat yang diselenggrakan oleh Persekutuan Doa Keluarga Besar Kristen di Kadisoka, Purwomartani, Kalasan, Sleman.

Slamet Suyanto. 2012. Pendidikan Karakter untuk Anak Usia Dini. Jurnal Pendidikan Anak, Volume 1, Edisi 1 Juni 2012.

Zulhan,Najib. 2010. Pendidikan Berbasis Karakter. Surabaya: JePe Press Media Utama. 


\title{
APLIKASI BELAJAR QUIZIZZ SEBAGAI AKTUALISASI PANCASILA DALAM MEDIA PEMBELAJARAN BAGI MAHASISWA DI MASA PANDEMI GOVID-19
}

\author{
Ni Wayan Swarniti \\ Fakultas Keguruan dan Ilmu Pendidikan Universitas Dwijendra \\ wayanswarniti@undwi.ac.id
}

\section{PENDAHULUAN}

Pancasila sebagai dasar negara Indonesia harus diaktualisasikan dalam kehidupan berbangsa dan bernegara. Selama ini banyak yang salah paham, bahwa Pancasila hanya berhubungan dengan masalah-masalah kenegaraan saja. Padahal Pancasila mampu memenuhi segala aspek kehidupan manusia, termasuk usaha manusia dalam mempelajari sesuatu. Dalam konteks pendidikan di masa pandemi Covid-19, Pancasila harus mampu diaktualisasikan melalui kegiatan pembelajaran. Kebutuhan diaplikasikannya Pancasila dalam media pembelajaran mengacu kepada sejarah kelahiran Covid-19 itu sendiri.

Pada bulan Desember 2019, pneumonia yang tidak dapat dijelaskan ditemukan di Wuhan, Cina, dan penyakit ini menyebar dengan cepat ke seluruh negeri (Lin, 2020). Pada tanggal 7 Januari 
2020, China mengidentifikasi pneumonia yang tidak diketahui etiologinya tersebut sebagai jenis baru coronavirus (novel coronavirus) (Liu, 2020). Pada awal tahun 2020 NCP mulai menjadi pendemi global dan menjadi masalah kesehatan di beberapa negara di luar RRC (Santika, 2020). Bahkan virus tersebut telah menyebar ke sejumlah negara, termasuk di Indonesia. Sampai saat ini virus ini dengan cepat menyebar masih misterius dan penelitian masih terus berlanjut (Yuliana, 2020). Berbagai upaya telah dilakukan oleh ahli medis dan Pemerintah Indonesia. Sayangnya hingga saat ini Pemerintah belum benar-benar mampu mengendalikan dan menghentikan penyebaran virus corona atau Covid-19 ini. Terbukti dengan meningkatnya jumlah kasus Covid19 yang terkomfirmasi di Indonesia.

Meskipun Pemerintah telah mengambil beberapa langkah dan kebijakan yang sesuai dengan Pancasila dengan tujuan mencegah atau mengendalikan penyebaran Covid-19 (Relman, 2020). Beberapa langkah Pancasilais yang diambil Pemerintah, misalnya dengan menerapkan kebijakan physical distancing atau menjaga jarak secara fisik di segala bidang kehidupan, selalu menggunakan masker medis sebagai alat proteksi diri bila berada di luar rumah, selalu mencuci tangan dengan sabun sebelum dan sesudah melakukan sesuatu, mandi besar dan membersihkan diri sesaat setelah pulang dari suatu tempat dan dilengkapi dengan penggunaan hand sanitizer untuk membunuh kuman ataupun virus pada tangan yang sangat mudah berpindah. Himbauan physical distancing atau menjaga jarak pada segala bidang kehidupan tanpa terkecuali juga diterapkan dalam bidang pendidikan. Pemerintah pun harus memutar otak dengan berfikir ekstra keras untuk mencari dan menemukan solusi terbaik yang dapat melindungi peserta didik dari ancaman Covid-19 ketika sedang menempuh pendidikan. Dalam situasi pandemi Covid-19, Pemerintah menghendaki pelaksanaan proses pembelajaran tetap berjalan dengan baik dan 
lancar. Karena itulah Pemerintah mengeluarkan himbauan yang dipertegas dengan kebijakan jaga jarak dalam pendidikan. Kebijakan physical distancing yang dilakukan oleh Pemerintah di bidang pendidikan dikemas dalam bentuk pembelajaran jarak jauh. Ini adalah solusi Pancasilais Pemerintah untuk tetap melaksanakan proses pembelajaran di masa pandemi Covid-19 seperti ini. Hal itu tertuang dalam Surat Edaran Kemdikbud Nomor 4 tahun 2020 tentang pelaksanaan kebijakan pendidikan dalam masa darurat Covid-19.

Metode belajar dengan sistem daring (dalam jaringan) pun dijadikan sebagai solusi Pancasilais untuk mengurai persoalan pendidikan karena munculnya pandemi Covid-19 di Indonesia (Swarniti, 2019). Sejak kebijakan tersebut dikeluarkan oleh Pemerintah, sudah lebih dari 12 bulan sistem belajar dari rumah dilakukan. Lamanya durasi waktu yang digunakan untuk sistem pembelajaran daring sudah barang tentu berdampak pada kondisi psikologis mahasiswa.

Kondisi psikologis tersebut tentunya dapat memberikan efek yang berpengaruh besar terhadap kejiwaan mahasiswa secara langsung (Endah Wulantina, 2019). Salah satu dampak psikologis yang mulai muncul dan mendera mahasiswa di tengah sistem pembelajaran daring saat ini adalah munculnya learning burnout atau kejenuhan belajar. Kejenuhan belajar ini dapat mempengaruhi daya serap mahasiswa terhadap materi pembelajaran yang disampaikan dosen. Dalam jangka panjangnya, kejenuhan belajar itu dapat mempengaruhi prestasi mahasiswa itu sendiri. Ekspresi kebosanan atau kejenuhan mahasiswa terkait sistem pembelajaran daring sudah banyak bertebaran di berbagai kanal media sosial. Bahkan menurut survei Ada Apa Dengan Covid-19 (AADC-19) Kementerian PPA, bahwa terdapat 58 persen anak mempunyai perasaan yang tidak menyenangkan selama belajar di rumah saja. 
Perasaan tidak menyenangkan yang memunculkan dan mengakibatkan kebosanan itu pada akhirnya berpengaruh signifikan terhadap rendahnya tingkat partisipasi dan keaktifan mahasiswa dalam kegiatan pembelajaran. Artinya jika tingkat partisipasi serta keaktifan mahasiswa pada saat proses pembelajaran melemah, maka prestasi mahasiswa tersebut juga ikut menurun. Dengan kata lain dunia pendidikan akan mengalami kemerosotan. Untuk mengantisipasi munculnya persoalan tersebut, pendidik atau dosen di masa pandemi Covid-19 dituntut untuk selektif dalam memilih aplikasi belajar yang akan digunakan mendukung pembelajaran daring (Mustofa et al., 2019). Dengan begitu aplikasi belajar yang dipilih dan digunakan adalah sesuai dengan Pancasila. Tentunya hal ini membuat test menjadi lebih baik dan mudah untuk dikerjakan (Swarniti, 2021). Dengan kata lain kejenuhan mahasiswa juga akan berkurang. Aplikasi belajar daring yang dipilih haruslah sesuai dengan Pancasila, yaitu menyenangkan, menantang, dan memotivasi mahasiswa dalam mengikuti perkuliahan. Salah satu aplikasi belajar daring yang layak dipertimbangkan untuk mengatasi kejenuhan mahasiswa dalam situasi pandemi Covid-19 adalah Quizizz.

\section{II.PEMBAHASAN}

Sebelum melangkah lebih jauh pada pembahasan tentang bagaimana cara menggunakan aplikasi Quzizz, terlebih dahulu dipaparkan penjelasan mengenai apa itu aplikasi Quzizz. Definisi ini dapat membantu Mahasiswa dalam memahami Quizizz sebagai aplikasi belajar. Selain itu, akan dipaparkan juga beberapa keunggulan dan kelemahan dari aplikasi Quizizz ini. Dalam pandangan Pancasila tentunya semakin memudahkan mahasiswa dalam memanfaatkan aplikasi belajar Quizizz. Dari perspektif Pancasila keuntungan aplikasi belajar Quiziz setidaknya mampu mendukung pembelajaran daring selama pandemi Covid-19. 
Misalnya dengan menggunakan aplikasi belajar Quizizz ini dosen dapat menyesuaikan situasi kelas dengan berbagai fitur yang telah tersedia. Fitur tersebut dapat dimanfaatkan seoptimal mungkin oleh dosen demi menciptakan suasana pembelajaran daring yang menantang, menyenangkan, dan memotivasi mahasiswa. Dengan begitu secara tidak langsung pemanfaatan aplikasi Quizizz dapat menumbuhkan motivasi mahasiswa untuk terus belajar dan meningkatkan prestasinya meski dalam situasi pandemi Covid-19 seperti sekarang ini. Dengan kata lain, proses pembelajaran di masa pandemi Covid-19 tidak akan terganggu dan tetap dapat berjalan lancar meski harus dilaksanakan melalui sistem daring yang bertumpu pada koneksi internet.

Di bawah ini merupakan penjelasan mengenai apa itu aplikasi belajar Quizizz, tata cara penggunaan aplikasi belajar Quizizz ini, dan kelebihan yang dapat dimanfaatkan, serta kekurangan yang harus diminimalisir demi berjalannya proses pembelajaran dengan baik.

\subsection{Pengertian Aplikasi Belajar Quizizz}

Quizizz merupakan sebuah web untuk membuat permainan kuis interaktif yang bisa digunakan dalam pembelajaran di kelas secara live atau dapat ditugaskan sebagai pekerjaan rumah (PR) bagi mahasiswa. Menurut Pancasila dalam situasi pandemi Covid-19 yang mengharuskan pembelajaran dilakukan secara daring, aplikasi Quizizz ini sangat bermanfaat untuk mendukung kegiatan perkuliahan. Apalagi setelah Indonesia lebih dari 10 bulan melakukan pembalajaran daring karena pandemi Covid-19. Dalam pandangan Pancasila, bahwa pembelajaran daring dengan menggunakan aplikasi belajar Quizizz merupakan sebuah inovasi. Terlebih karena kegiatan belajar mengajar sebelum pandemi Covid-19 dilakukan secara klasikal, yaitu tatap muka. Namun 
perlulah dipahami, bahwa pembelajaran daring yang berlangsung dalam situasi yang cukup lama akan memacu dan memicu munculnya kejenuhan mahasiswa (Santika, 2018). Dalam keadaan seperti ini kehadiran Quizizz sebagai aplikasi pembelajaran daring sangat dibutuhkan mahasiswa dalam mengusir kejenuhan belajar yang selalu menghinggapinya. Dengan begitu, salah satu cara untuk menurunkan dan menghilangkan tingkat kejenuhan mahasiswa saat pembelajaran adalah dengan memberikannya kuis melalui aplikasi Quizizz. Apalagi aplikasi belajar ini berbasis game atau permainan yang menampilkan gambar-gambar kartun yang mampu menarik perhatian mahasiswa. Dalam Perspektif Pancasila, dengan memanfaatkan aplikasi belajar Quizizz mahasiswa pun merasa tertarik, senang, dan nyaman serta termotivasi dalam mengikuti pembelajaran. Dengan munculnya efek psikologis seperti itu tentunya mampu merangsang dan menumbuhkan semangat mahasiswa dalam pembelajaran. Hal itu dapat dilihat atau diukur dari tingkat keaktifan dan partisipatisi Mahasiswa dalam mengikuti pembelajaran daring selama pandemi Covid-19. Aplikasi belajar Quizizz dalam situasi pandemi Covid-19 adalah sesuai dengan Pancasila karena memiliki kelebihan tersendiri. Kelebihan pembelajaran melalui Quizizz yang berbasis game ini tampak nyata dari daya tahan mahasiswa dalam mengingat materi pembelajaran. Karena dengan menggunakan apalikasi belajar Quizizz, materi kuliah yang dipelajari mahasiswa dapat berkesan dan melekat lebih kuat ser ta mampu bertahan lebih lama.

Dalam perspektif Pancasila dengan menggunakan aplikasi belajar Quizizz dalam sistem pembelajaran daring, secara psikologis adrenalin mahasiswa akan merasa tertantang. Mengingat kuis yang diberikan melalui Quizizz harus dikerjakan mahasiswa secara online dengan batas waktu yang telah ditentukan oleh dosennya. Dengan begitu, suasana pembelajaran daring yang menantang dengan menggunakan aplikasi belajar Quizizz dapat 
dilihat dari adanya timer yang berfungsi mengatur waktu kapan kuis akan dibuka dan kapan akan berakhir. Di sini mahasiswa akan merasa tertantang untuk berpikir cepat dan tanggap dalam mengatur strategi jitu untuk dapat menyelesaikan pertanyaan dosen tepat pada waktunya. Dengan adanya timer dalam pengerjaan soal, aplikasi belajar Quizizz sebenarnya dapat digunakan dosen untuk melatih kedisiplinan dan kebiasaan mahasiswa untuk menghadapi permasalahan. Kedisiplinan dan kebiasaan mahasiswa dalam menghadapi tenggang waktu dengan sendirinya akan terpupuk. Dalam jangka panjang jika sudah terbiasa berpacu dengan waktu, maka mahasiswa akan merasakan ketenangan menjawab soal-soal yang diberikan dosen kepadanya. Selain itu, timer pada Quizizz juga membantu mahasiswa untuk lebih fokus dalam mengikuti pembelajaran daring selama pandemi Covid-19. Di samping itu, Quizizz juga dapat memupuk dan membentuk rasa tanggungjawab mahasiswa dengan apa yang seharusnya dikerjakan. Selain itu, penggunaan aplikasi belajar Quizizz juga memunculkan tantangan tersendiri bagi mahasiswa untuk mendorong semangat belajarnya.

\subsection{Tata Cara Penggunaan Aplikasi Belajar Quizizz}

a. Cara Membuat Akun di Aplikasi Belajar Quizizz

Langkah 1

Langkah pertama yang dapat dilakukan bagi seorang dosen yang ingin menggunakan dan memanfaatkan aplikasi belajar ini adalah dengan masuk ke situs https://quizizz.com/. Situs ini dapat dicari dan ditemukan melalui Google Chrome.

\section{Langkah 2}

Saat berada dalam web tersebut, dapat memulai dengan menklik sign up untuk membuat akun baru. Pengguna dapat sign up dengan menggunakan akun google, atau dengan memasukkan email pengguna. Usahakan menggunakan email yang masih aktif dan yang paling sering digunakan. 


\section{Langkah 3}

Setelah berhasil mendaftar dengan sign up, dilanjutkan dengan memilih peran pengguna dalam aplikasi belajar Quizizz ini. Peran yang dapat dunakan pengguna antara lain dosen (teacher), orang tua (parent), dan siswa (student). Jika pengguna adalah seorang dosen dapat memilih peran sebagai dosen (teacher) dengan menklik a teacher.

\section{Langkah 4}

Kemudian langkah selanjutnya, yaitu dengan mengisi dan melengkapi data sesuai data pribadi pengguna seperti: memilih negara asal, masukkan kode pos daerah asal, memasukkan nama sekolah, perguruan tinggi atau institusi secara manual dengan cara menklik can't find your organization. Dilanjutkan dengan menklik add organization. Untuk langkah terakhir dalam pembuatan akun bagi pengguna yaitu dengan menklik continue.

b. Cara Membuat Soal di Aplikasi Belajar Quizizz

Setelah selesai membuat akun, langkah selanjutnya yang dapat dilakukan pengguna adalah membuat soal di aplikasi belajar Quizizz. Untuk itu, pengguna dapat mengikuti langkah-langkah procedural sebagai berikut:

\section{Langkah 1}

Langkah pertama untuk membuat soal pada aplikasi belajar Quizizz ini yaitu dengan menklik open quiz creator atau buat soal.

\section{Langkah 2}

Langkah selanjutnya pengguna dapat mengisi data yang terkait dengan soal-soal yang akan dibuat, seperti: memasukkan nama kuis yang akan dibuat, contohnya "Grammar Exercise". Kemuadian dapat memilih bahasa apa yang akan digunakan 
dalam menulis kuis. Pengguna dapat menggunakan bahasa Indonesia atau bahasa Inggris, sesuai dengan kebutuhan soal. Lalu dilanjutkan dengan memasukkan gambar untuk kuis. Gambar ini boleh diisi dan boleh juga tidak diisi. Hanya saja dengan adanya gambar akan lebih menarik dan memotivasi siswa dalam menjawab soal. Gambar ini difungsikan sebagai ikon dari soal yang akan dibuat pengguna. Setelah semua data mengenai soal sudah terisi dengan jelas, proses ini dapat diakhiri dengan menklik save atau simpan.

\section{Langkah 3}

Langkah berikutnya pengguna dapat memulai untuk membuat pertanyaan dan jawaban dengan menklik create new question atau membuat pertanyaan baru pada aplikasi belajar ini.

\section{Langkah 4}

Selanjutnya pengguna akan dibawa ke halaman pembuatan soal. Pengguna dapat memulai mengisikan dan melengkapi data yang berkaitan dengan soal yang akan dibuat sesuai dengan keterangan berikut.

Single answer adalah soal dengan satu jawaban benar. Multy select, adalah soal dengan jawaban benar lebih dari satu. Pembuatan soal dapat dengan tulisan dapat juga dilengkapi dengan video, audio, ataupun gambar. Pilihan jawaban dapat dibuat lebih dari empat pilihan. Pilihan jawaban ini dapat dibuat dalam bentuk tulisan atau gambar. Jika terdapat kesalahan dalam penginputan jawaban, dapat dihapus dengan menekan ikon tong sampah. Untuk jawaban yang benar, pengguna dapat menklik tanda centang di sebelah kiri sampai berwarna hijau. Pilihan jawaban yang memiliki centang hijau dapat digunakan sebagai kunci jawaban. Terdapat pula kolom untuk mengatur waktu menjawab yang bisa dipilih dan dimanfaatkan pengguna 5, 10, 15, 20, dan seterusnya (waktu dalam detik). Jika seluruh data 
mengenai soal telah terisi, pengguna atau dosen dapat menklik save atau simpan untuk menyimpan soal yang telah dibuat dan diatur.

\section{Langkah 5}

Dosen dapat membuat soal sebanyak mungkin, yaitu sesuai dengan kebutuhannya. Jika sudah dianggap lengkap, dosen dapat menklik finish quiz kemudian dapat melanjutkannya dengan mengisikan kelas (grade) dan bidang keilmuan yang terkait dengan soal (choose relevance subject) pada soal yang dibuat.

c. Cara Memberikan Soal Quizizz Kepada Mahasiswa.

Setelah kuis selesai dibuat, langkah yang dapat dilakukan dosen selanjutnya adalah memberikan kuis tersebut kepada mahasiswa. Langkah-langkah yang harus dilakukan agar dosen dapat memberikan kuis tersebut kepada mahasiswa yaitu sebagai berikut:

\section{Langkah 1}

Terdapat dua jenis metode permainan yang dapat dimainkan pada aplikasi belajar Quizizz. Cara yang pertama dengan permainan langsung (live game) dan dengan metode lain yaitu menjadikan sebagai pekerjaan rumah (homework). Jika dosen memilih menggunakan cara permainan langsung (live game) dapat memulai dengan menklik live game, namun jika dosen memilih menjadikan sebagai pekerjaan rumah dapat menklik homework untuk memulai.

\section{Langkah 2}

Dalam permainan langsung (live game), dosen dapat mengatur beberapa fungsi seperti: pertanyaan dapat diacak, jawaban dapat diacak. setelah menyelesaikan permainan siswa dapat melihat jawaban yang benar, selama permainan berlangsung dapat diiringi dengan miusik. dan siswa dapat melihat gambar-gambar 
lucu. Beberapa hal tersebut membuat siswa merasa tertarik dalam menyelesaikan permainan.

\section{Langkah 3}

Jika pengaturan sudah selesai dilakukan, dilanjutkan dengan menklik proceed, maka kuis sudah siap diberikan kepada siswa. Dosen dapat meminta siswa untuk mengetik join.quizizz.com di browser telpon genggam dan memasukan kode permainannya.

\section{d. Cara Bergabung Pada Kuis Online Quizizz}

Cara ini dapat dilakukan oleh mahasiswa yang ingin bergabung pada kuis yang diberikan oleh dosen mereka.

Langkah 1

Langkah pertama yang dapat dilakukan oleh mahasiswa yaitu memasuki website join.quizizz.com dan kemudian menklik ikon join.

\section{Langkah 2}

Dosen dapat meminta mahasiswa memasukkan game code, kemudian memasukkan nama mereka. Mahasiswa yang telah bergabung akan terlihat di layar laptop atau komputer dosen. Kuis dapat dimulai setelah seluruh mahasiswa bergabung di dalam kuis. Dosen hanya perlu menklik start untuk memulai permainan.

\subsection{Kelebihan Penggunaan Aplikasi Belajar Quizizz}

a. Mudah Dikerjakan Dimana Saja

Permainan pada aplikasi belajar Quizizz sangat mudah dikerjakan di mana pun dan kapan pun sesuai kesepakatan dosen dan mahasiswanya. Kemudahan penggunaan aplikasi belajar Quizizz karena tidak harus dikerjakan melalui komputer atau laptop. Permainan dalam aplikasi belajar Quizizz ini dapat dengan mudah dikerjakan melalui smart phone mahasiswa. Hal itu tentu membantu memudahkan mahasiswa dalam mengikuti pembelajaran daring selama pandemi Covid-19. Sebab mahasiswa tidak perlu susah-susah membawa laptop atau 
komputer ke mana-mana. Cukup dengan menggunakan smart phone, mahasiswa sudah dapat mengikuti pembelajaran daring dengan menggunakan aplikasi belajar Quzizz. Terlebih lagi pada zaman modern seperti sekarang ini, hampir sebagian besar lapisan masyarakat Indonesia sudah memiliki smart phone masing-masing. Banyak tipe smart phone yang dapat dimanfaatkan pada proses pembelajaran secara daring atau dalam jaringan. Secara tidak langsung keberadaan smart phone ini ternyata memberikan sumbangsih yang sangat berarti bagi perkembangan dan kemajuan dunia pendidikan. Dengan lahirnya aplikasi Quizizz yang dapat digunakan melalui smart phone, setidaknya kehadiran pandemi Covid-19 bukan lagi menjadi penghalang utama bagi mahasiswa dalam menikmati pembelajaran daring.

Terlebih lagi smart phone dapat digunakan dimana saja tanpa mengenal tempat. Dimana pun dan kapapun, asalkan sesuai dengan kesepakatan bersama dosen, mahasiswa dapat belajar hanya dengan smart phonenya masing-masing. Dengan kata lain, pembelajaran daring dengan aplikasi belajar Quizizz tidak terbatas oleh tempat tetapi tergantung pada kesepakatan dosen dan mahasiswa. Berarti aplikasi belajar Quizizz sesuai dengan fleksibelitas pembelajaran daring selama pandemi Covid-19. Karena aplikasi belajar Quizizz yang berbasis permainan ini dapat dikerjakan di mana saja dan kapan saja, seperti: di rumah, di sekolah, di lapangan, di tempat kerja, di tempat ibadah, bahkan di rumah sakit sekali pun. Hal itu sesuai dengan tumpuan keberhasilan penggunaan aplikasi belajar Quizizz yang sangat tergantung pada kesepakatan bersama antara dosen dengan mahasiswa. Hal ini tentunya menawarkan sebuah kemudahan dan pleksibelitas bagi mahasiswa untuk mengakses maupun mengerjakan soal-soal yang ada pada permainan tersebut. 
b. Terdapat Pengaturan Waktu

Waktu adalah kata kunci yang menentukan keberhasilan dalam pembelajaran. Tidak heran bila keberhasilan pendidikan sangat tergantung pada kemampuan seseorang dalam mengatur dan menentukan waktunya. Begitu juga dengan pemilihan dan penggunaan aplikasi belajar di masa pandemi Covid-19. Hendaknya aplikasi belajar yang dipilih dosen di dalamnya terdapat pengaturan waktu bagi mahasiswa dalam mengerjakan dan menyelesaikan tugas-tugasnya. Jika diperhatikan pada aplikasi belajar Quizizz, tersedia pengaturan waktu dalam pengerjaan soal. Pengaturan waktu pada permainan ini dapat dimanfaatkan oleh dosen untuk meningkatkan daya ingat, menjaga konsentrasi mahasiswa, dan kecekatan atau ketangkasannya dalam menjawab pertanyaan pada permainan ini. Dosen dengan leluasa bisa mengatur batas waktu bagi mahasiswanya dalam menjawab setiap soal atau pertanyaan yang diberikannya. Tergantung rancangan belajar dosen, bahwa setiap soal dapat memiliki batas waktu pengerjaan yang berbeda sesuai dengan bobot pengerjaannya. Semua ini dapat dengan mudah diatur oleh dosen.

Kecekatan dan ketangkasan mahasiswa dalam menjawab soal akan diuji dengan fitur ini. Dengan diaturnya batas waktu pengerjaan, mahasiswa akan merasa terpacu untuk segera menyelesaikan dan menjawab soal yang diberikan dosen. Mahasiswa dengan sendirinya merasa berlomba dalam mengerjakan soal yang berbentuk permainan ini. Secara tidak langsung, dosen sebenarnya telah berhasil menciptakan situasi kompetitif antara mahasiswa dalam pembelajaran daring selama pandemi Covid-19. Dinamika kompetitif atau daya saing yang diperoleh melalui pembelajaran dengan aplikasi belajar Quizizz sangat baik bagi perkembangan mahasiswa. Hal itu, dapat digunakan untuk merangsang, memunculkan, dan memacu jiwa mahasiswa sebagai pejuang. Berarti dengan aplikasi belajar 
Quizizz, mahasiswa diajarkan untuk tidak mudah pantang menyerah dalam menghadapi persaingan. Mengingat hidup ini penuh dengan kompetisi atau persaingan.

c. Sulit Dalam Hal Menyontek

Setelah sekian lama saling mengenal dalam kegiatan pembelajaran, sebenarnya dosen sangat mengetahui bagaimana kondisi kepribadian atau karakter mahasiswanya masingmasing. Dosennya tentu sudah tahu dan mampu mengklasifikasikan mahasiswanya menurut sifat-sifat yang dimilikinya. Apakah mahasiswanya memiliki sifat baik dan buruk terutama dalam kelas saat pmengikuti pembelajaran, saat kuis, saat persentasi bahkan saat ujian. Faktanya di lapangan tidak sedikit mahasiswa yang ingin memperoleh nilai baik tanpa melalui proses yang benar. Mereka berusaha meminta jawaban dari teman sejawatnya saat mengerjakan ujian. Hal ini dilakukan dengan berbagai faktor pendukung seperti: malas berfikir, belum belajar, ingin nilai yang lebih baik, bahkan tidak pernah kuliah. Situasi tersebut pada gilirannya mendorong mereka melakukan tindakan tidak terpuji, yaitu menyontek jawaban dari temannya saat ujian sedang berlangsung.

Dengan penggunaan aplikasi belajar Quizizz dalam pembelajaran dari selama pandemi Covid-19, paling tidak dapat mengurangi, meminimalisir, bahkan menghilangkan kecurangan intelektual. Dengan begitu, tindakan contekmenyontek yang sudah membudaya dan mengakar di antara mahasiswa dapat ditekan seminimal mungkin. Hal ini dikarenakan permainan pada aplikasi belajar Quizizz ini dapat diakses dimana pun. Dengan kata lain, bahwa permainan ini dapat dikerjakan di rumah mahasiswa masing-masing. Jadi tidak adanya kedekatan secara fisik, sehingga membuat mahasiswa mengerjakan soalnya ini secara murni tanpa bantuan dari rekan sejawatnya. Secara otomastis mahasiswa akan 
menjawab soal atau kuis tersebut berdasarkan kemampuannya sendiri tanpa dibantu atau meminta bantuan dari temannya.

Dengan aplikasi belajar Quizizz ini, dosen secara mudah dapat melihat dan memantau proses pengerjaan kuis oleh masingmasing mahasiswa. Dengan cara seperti ini setidaknya akan menggampangkan dosen untuk mengamati dari kejauhan setiap perkembangan pertanyaan dan jawaban yang sudah selesai dikerjakan oleh masing-masing mahasiswa. Dosen pun akan lebih mudah melakukan penilaian dan evaluasi pada setiap mahasiswanya. Maka akan terlihat jika seorang mahasiswa memiliki jawaban yang sama ataupun waktu pengerjaan yang sama dengan mahasiswa yang lain berdasarkan hasil yang terekam pada aplikasi belajar Quizizz ini.

d. Bentuk Pertanyaan yang Menarik

Pada aplikasi belajar Quizizz, bentuk pertanyaan yang disajikan dapat menjadi salah satu alasan mengapa permainan ini dapat menurunkan tingkat kejenuhan mahasiswa saat proses pembelajaran daring selama masa pendemi Covid-19 seperti saat ini. Bentuk soal yang dapat dimanfaatkan dosen tidak hanya soal yang berbentuk tulisan seperti biasa, namun dosen dapat pula memanfaatkan fitur pembuat soal dengan video, audio, bahkan gambar. Hal ini dapat menarik minat mahasiswa untuk mengikuti pembelajaran daring yang berlangsung selama pandemi Covid-19. Lebih daripada itu pada ilmu kebahasaan, fitur pembuatan soal dalam aplikasi belajar Quizizz dengan menambahkan video atau audio akan memudahkan dosen dalam penyampaian soal pada mahasiswa. Hal ini akan berdampak pada banyaknya jawaban-jawaban tepat yang dipilih oleh mahasiswa tersebut.

Selain hal tersebut, bentuk pertanyaan yang unik dalam aplikasi belajar Quizizz dapat meningkatkan motivasi dan memacu semangat mahasiswa dalam mengerjakan setiap soal pada permainan tersebut. Mahasiswa tidak monoton disuguhkan 
pada tulisan yang menjejali setiap pertanyaan yang ada pada permainan, tetapi mahasiswa dapat melihat pertanyaan yang variatif, sehingga tidak mudah merasa jenuh dalam menjawab pertanyaan pada kuis. Mahasiswa pun merasa tidak bosa mengikuti perkuliahan yang diberikan secara daring selama pandemi Covid-19. Dengan kata lain, aplikasi belajar Quizizz dapat merangsang dan membangkitkan semangat belajar mahasiswa dalam mengikuti perkuliahan daring selama pandemi Covid-19. Mahasiswa dapat termotivasi untuk segera menyelesaikan pertanyaan yang satu agar dapat segera melihat pertanyaan unik berikutnya.

e. Terdapat Gambar-Gambar yang Menarik.

Selain terdapat pertanyaan yang unik pada setiap soalnya pada permainan aplikasi belajar Covid-19 ini juga tersedia gambargambar yang sangat menarik dan memikat hati mahasiswa. Gambar-gambar ini dapat muncul pada situasi-situasi tertentu, seperti: pada awal permainan dimulai, saat menjawab benar, saat menjawab salah, saat permainan berakhir. Hal ini sedikit tidaknya akan membantu mengurangi beratnya tekanan berpikir mahasiswa dalam menjawab pertanyaan pada kuis. Selain gambar, terdapat pula penghitung waktu mundur saat permainan akan dimulai. Hal ini dapat mendorong kesiapan jiwa mahasiswa dalam menjawab pertanyaan yang diberikan dosen. Di samping itu, akan memberikan efek perlombaan pada setiap mahasiswa yang mengerjakan. Mahasiswa juga dapat menyiapkan diri dan mulai berkonsentrasi pada fase ini.

f. Terdapat Sistem Perengkingan

Pada aplikasi belajar quizizz ini terdapat pula sistem perengkingan. Setelah selesai mengisi jawaban, sistem juga dapat memberikan poin setiap pemain berdasarkan jumlah jawaban yang tepat dan kecepatan menjawab setiap pertanyaan. Hal ini akan membangkitkan motivasi setiap mahasiswa untuk menjawab pertanyaan dengan benar sebanyak mungkin. Berarti 
dengan adanya poin ini dapat membuat mahasiswa lebih serius lagi berpikir untuk menjawab soal-soal yang ada. Dengan kata lain mahasiswa akan berebut dan berkompetisi dengan temantemannya untuk mendapatkan kedudukan. Setiap mahasiswa akan berlomba-lomba untuk menjadi juara pertama dengan menjawab pertanyaan secara benar. Di sisi lain hal ini juga dapat dimanfaatkan dosen untuk mengukur hasil kuis dari setiap mahasiswa.

Dengan adanya sistem ini, mahasiswa juga dapat mengukur dan mengetahui seberapa besar kemampuannya masing-masing. Mahasiswa dapat melihat jawabannya, kira-kira pada soal nomor berapa saja yang keliru dan mana saja soal yang dijawab dengan tepat. Hal ini juga dapat digunakan sebagai bahan evaluasi diri dan perbaikan bagi mahasiswa itu sendiri. Mahasiswa pun dapat mengetahui dimana letak kelemahan dan kelebihan dalam penguasaan materi pembelajaran. Dengan demikian, mahasiswa dapat intropeksi dan merefleksikan diri atas kemampuannya dalam menyerap materi yang diberikan dosennya (Santika, 2017).

\subsection{Kekurangan Penggunaan Aplikasi Belajar Quizizz}

a. Memerlukan Koneksi Internet

Permainan pada aplikasi belajar Quizizz hanya dapat dilakukan dalam jaringan atau berbasis online. Artinya diperlukan koneksi internet untuk menggunakan aplikasi belajar Quizizz ini. Sedangkan kita ketahui, bahwa tidak semua daerah di Indonesia sudah memiliki akses atau mampu dijangkau internet. Dengan kata lain, untuk memanfaatkan aplikasi belajar Quizizz dalam perkuliahan sangat diperlukan koneksi internet yang baik dan stabil. Karena tanpa koneksi yang stabil mahasiswa tidak mungkin dapat menyelesaikan permainan ini dengan lancar atau tanpa hambatan. Namun sayangnya tidak semua mahasiswa memiliki koneksi internet yang mumpuni untuk mengikuti kuis tepat pada waktunya. Hasilnya adalah sering 
kali terdapat beberapa mahasiswa yang terlambat bergabung pada permainan, sehingga hanya memiliki sedikit waktu yang tersisa untuk menjawab seluruh pertanyaan yang ada pada kuis. Tidak sedikit pula mahasiswa yang akhirnya gagal menyelesaikan permainan dalam aplikasi belajar Quizizz ini, karena koneksi internet yang sangat buruk saat perkuliahan dimulai. Hal ini biasanya akan menjadi dilema tersendiri bagi setiap dosen dalam melaksanakan proses perkuliahan secara online. Di satu sisi dosen ingin berinovasi melalui aplikasi belajar Quizizz dengan memberikan perkuliahan yang menerapkan pendekatan baru atau metode yang berbeda dari biasanya. Namun di sisi lain, dosen merasa memberatkan mahasiswa untuk mencari daerah yang memiliki koneksi internet yang baik dan lancar.

b. Memerlukan Sinyal yang Baik

Selain koneksi internet yang baik, sinyal yang lancar dan stabil juga sangat berperan dan mempengaruhi berjalan baik atau tidaknya permainan pada aplikasi belajar Quizizz ini. Jika mahasiswa berada di daerah perkotaan hal tersebut tidak mungkin menjadi masalah yang sulit. Lain halnya jika mahasiswa berada di daerah pedesaan, sinyal sangat sulit ditemukan. Bila mahasiswa berada di desa sering kali mengakibatkan tidak lancarnya koneksi atau jaringan pada smart phonnnya. Dengan kata lain, mahasiswa terhambat menyelesaikan permainan atau tidak dapat mengikuti permainan tepat pada waktunya.

Dikarenakan hal tersebut, mahasiswa yang sedang mengikuti perkuliahan harus mencari alternatif lain agar tetap dapat menemukan sinyal yang bagus. Karena dengan jalan seperti itu, mahasiswa tetap mengikuti perkuliahan secara daring melalui Quizziz. Hal tersebut dapat dilakukan dengan mencari daerah yang memiliki sinyal internet yang lebih stabil. Dengan kata 
lain, mahasiswa harus keluar dari rumahnya yang ada di pedesaan untuk mencari daerah yang sinyal internet lebih baik.

\section{PENUTUP}

Berdasarkan penjelasan di atas, dapat ditarik simpulan bahwa penggunaan aplikasi belajar Quizizz adalah sesuai dengan Pancasila karena dapat memberikan dampak yang positif bagi mahasiswa. Mahasiswa mendapat pengalaman baru, suasana baru, dan cara belajar baru dalam pembelajaran daring. Dengan aplikasi belajar Quizizz, pembelajaran daring yang dilakukan akan menantang, menyenangkan, dan memotivasi mahasiswa selama masa pandemi Covid-19 seperti saat ini.

\section{DAFTAR PUSTAKA}

Adi, S. W. (2020, October). Peluang \& Tantangan Generasi

Milenial Dalam Menghadapi Era Society 5.0. Jawa Pos Radar Solo.

Anderson, J. E., \& Bunch, H. C. (1989). Agricultural property tax relief: tax credits, tax rates, and land values. Land Economics, 65(1), 13-22. https://doi.org/10.2307/3146259

Anderson, John E. (1993). Use-Value Property Tax Assessment:

Effects on Land Development. Land Economics, 69(3), 263. https://doi.org/10.2307/3146592

Anderson, John E. (2012). Agricultural Use-Value Property Tax Assessment: Estimation and Policy Issues. https://doi.org/10.1111/j.1540-5850.2012.01025.x

Anderson, John E, Giertz, S. H., Shimul, S. N., \& Family, B. (2015). Property Taxes for Agriculture Use-Value Assessment and Urbanization across the United States. 
Assingkily, M. S., Putro, K. Z., \& Sirait, S. (2019). Kearifan

Menyikapi Anak Usia Dasar di Era Generasi Alpha (Ditinjau dari Perspektif Fenomenologi). Attadib: Journal of Elementary Education, 3(2), 1-21.

Boonyanam, N. (2019). Agricultural Zoning and Policy Conflict:

Thailand's Experience. In Land Use - Assessing the Past,

Envisioning the Future. IntechOpen.

https://doi.org/10.5772/intechopen.80262

BPIP. (2020). Cara Mudah Menanamkan Nilai-nilai Pancasila Pada Anak Sejak Kecil. Bpip.Go.Id.

Bryant, C. (2017). What Can Agricultural Land Use Planning Contribute to Food Production and Food Policy? International International Journal of Avian \& Wildlife Biology, 2(1). https://doi.org/10.15406/ijawb.2017.02.00009

Darmawan, M. J., \& Tukiman, T. (2020). ANALISIS DIMENSI KETIMPANGAN PEMBANGUNAN ANTAR WILAYAH DI PROVINSI JAWA TIMUR TAHUN 2014-2018.

Dinamika Governance : Jurnal Ilmu Administrasi Negara, 10(1). https://doi.org/10.33005/jdg.v10i1.2045

Dedy Darmawan Nasution. (2020). Tiap Tahun, 60 Ribu Hektare Lahan Pertanian Menyusut | Republika Online.

Dewantara, J. A., Suhendar, I. F., Rosyid, R., \& Atmaja, T. S. (2019). Pancasila as Ideology and Characteristics Civic Education in Indonesia. International Journal for Educational and Vocational Studies, 1(5), 400-405. https://doi.org/10.29103/ijevs.v1i5.1617

Endah Wulantina, S. M. (2019). Persepsi Peserta Didik terhadap Metode Blended Learning dengan Google Classroom. Jurnal Inovasi Matematika, 1(2), 110-121.

https://doi.org/10.35438/inomatika.v1i2.156 
Fajarini, U. (2014). Peranan Kearifan Lokal Dalam Pendidikan Karakter. SOSIO DIDAKTIKA: Social Science Education Journal, 1(2). https://doi.org/10.15408/sd.v1i2.1225

Fauzi, M. R. (2019). Ketimpangan, Pola Spasial, dan Kinerja Pembangunan Wilayah di Provinsi Jawa Timur. Journal of Regional and Rural Development Planning (Jurnal Perencanaan Pembangunan Wilayah Dan PerdesaanJP2WD), 2019(3), 157-171. https://doi.org/10.29244/jp2wd.2019.3.3.157-171

Febriansyah, F. I. (2017). Keadilan Berdasarkan Pancasila Sebagai Dasar Filosofis Dan Ideologis Bangsa. DiH: Jurnal Ilmu Hukum, 13(25), 1. https://doi.org/10.30996/dih.v13i25.1545

Fitriarti, E. A. (2019). Urgensi Literasi Digital Dalam Menangkal Hoax Informasi Kesehatan Di Era Digital.

Metacommunication: Journal of Communication Studies, 4(2), 219. https://doi.org/10.20527/mc.v4i2.6929

Haryanti, R. (2019, January). “Society 5.0”, Solusi Jepang Atasi

Defisit Penduduk dan Infrastruktur. Kompas.Com.

Hidayatullah, R. (2020). Pendidikan Musik: Pendekatan Musik Untuk Anak di Era 4.0. CV. Rumah Kayu Pustaka Utama.

Irwansyah, R., Darmayani, S., Mastikawati, M., Saputro, A. N. C., Wihartanti, L. V., Fauzi, A., Arifudin, O., Purandina, I. P. Y., Latifah, E. D., Septiyani, T., Pangestika, R. R., Fatayah, F., Ayuningtyas, P., Lemba, V. C., \& Hartono, R. (2021). PERKEMBANGAN PESERTA DIDIK . In Widina Bhakti Persada Bandung. Widina Bhakti Persada Bandung.

Lin, D. (2020). COVID-19 pneumonia patient without clear epidemiological history outside Wuhan: An analysis of the radiographic and clinical features. Clinical Imaging, 65, 8284. 
Liu, D. (2020). COVID-19: The first documented coronaviruspandemic in history. Biomedical Journal, 1-6.

Metzger, J. T. (1996). The Theory and Practice of Equity Planning: An Annotated Bibliography. Journal of Planning Literature, 11(1), 112-126. https://doi.org/10.1177/088541229601100106

Mustofa, M. I., Chodzirin, M., Sayekti, L., \& Fauzan, R. (2019).

Formulasi Model Perkuliahan Daring Sebagai Upaya

Menekan Disparitas Kualitas Perguruan Tinggi. Walisongo

Journal of Information Technology, 1(2), 151.

https://doi.org/10.21580/wjit.2019.1.2.4067

Nordquist, M. (2013). Seeking spatial justice by Edward W. Soja.

Contemporary Political Theory, 12(1), e16-e18.

https://doi.org/10.1057/cpt.2011.40

OECD. (2020). Taxation in Agriculture. In Taxation in Agriculture.

OECD. https://doi.org/10.1787/073bdf99-en

Perrin, C., Clément, C., Melot, R., \& Nougarèdes, B. (2020). land

Preserving Farmland on the Urban Fringe: A Literature

Review on Land Policies in Developed Countries.

https://doi.org/10.3390/land9070223

Philippopoulos-Mihalopoulos, A. (2014). The Movement of Spatial Justice. MONDI MIGRANTI, 1, 7-19.

https://doi.org/10.3280/mm2014-001001

Relman, E. (2020). Business insider Singapore.

Rustiadi, E. (2001). Pergeseran Menuju Paradigma Baru

Pengembangan Wilayah. Forum Diskusi Pengembangan

Metode, Puslitbang Ketenagakerjaan Dan Ketransmigrasian,

Departemen Tenagakerja Dan Transmigrasi.

Santika, I. G. N. (2017). Kepala Sekolah Dalam Konsep

Kepemimpinan Pendidikan: Suatu Kajian Teoritis. Widya 
Accarya, 7(1).

http://103.39.12.42/index.php/widyaaccarya/article/view/898

Santika, I. G. N. (2018). Strategi Meningkatkan Kualitas SDM

Masyarakat Desa Padangsambian Kaja Melalui Pendidikan

Karakter Berbasiskan Kepedulian Lingkungan Untuk

Membebaskannya Dari Bencana Banjir. Widya Accarya, 9(1).

Santika, I. G. N. (2019). Pendidikan Karakter: Studi Kasus Peranan

Keluarga Terhadap Pembentukan Karakter Anak Ibu Sunah Di

Tanjung Benoa. Widya Accarya, 10(1).

https://doi.org/https://doi.org/10.46650/wa.10.1.864.\%25p

Santika, I. G. N. (2020). Optimalisasi Peran Keluarga Dalam

Menghadapi Persoalan Covid- 19 : Sebuah Kajian Literatur.

Jurnal Ilmiah Ilmu Sosial, 6(2), 127-137.

https://doi.org/http://dx.doi.org/10.23887/jiis.v6i2.28437

Septiawan, Y., Purandina, I. P. Y., Jumari, Tafonao, T., Ramlan, A.

M., Dewi, N. P. C. P., Tambuanan, T. S., Zaedun, N., Arlotas,

R. K., Suryaningwidi, R., \& Muvid, M. B. (2020). Strategi

dan Metode Pembelajaran Era Society 5.0 di Perguruan

Tinggi (Y. Septiawan \& M. B. Muvid (eds.)). Goresan Pena.

Setiyani, S., Dasilah, \& Nurcahyo, D. N. (2020). Paradigma Baru

Pendidikan Era Disruptif Menuju Masyarakat 5.0. Prosiding

Seminar Nasional Pendidikan Program Pascasarjana

Universitas Pgri Palembang 10 Januari 2020, 747-756.

Soja, E. W. (2008, March). The city and spatial justice. Spatial Justice.

Sunoto. (1984). Mengenal Filsafat Pancasila : Pendekatan melalui metafisika logika etika. Hanindita.

Suparman. (2012). Pancasila. Balai Pustaka.

Swarniti, N. W. (2019). The Translation Procedures of Bible 
Translation. RETORIKA: Jurnal Ilmu Bahasa, 5(2), 187-196. https://doi.org/10.22225/jr.5.2.1277.187-196

Swarniti, N. W. (2021). A Corpus Based Approach to the Analysis of Structures in Prepositional Phrase. Yavana Bhasha: Journal of English Language Education, 4(1), 18-22.

Widyawati Agustin, I., \& Kubota, H. (2012). Changing Physic, Changing Pattern, and Conflicts of Rural-Urban Fringe Using a Combination Model. J. Basic. Appl. Sci. Res, 2(12), 1272212730.

Wijaatmaja, A. B. M. (2015). PENDEKATAN PERENCANAAN TATA RUANG WILAYAH DI KOTA DENPASAR - PDF Free Download. Program Pascasarjana Universitas Udayana.

Yuliana. (2020). Corona virus diseases (Covid -19); Sebuah tinjauan literatur. Wellness and Healthy Magazine, 2(1), 187192.

Yunus, H. S. (1990). Searching new strategies for managing and controlling urban land growth: a preliminary outlook on Indonesia. Indonesian Journal of Geography, 20(60), 1-10. https://doi.org/10.22146/IJG.2188

Yunus, H. S. (2005). Manajemen kota : perspektif spasial. 


\title{
TATA GUNA LAHAN DAN PENATAAN RUANG YANG BERKEADILAN SPASIAL
}

\author{
Arya Bagus Mahadwijati Wijaatmaja
}

Fakultas Teknik Universitas Dwijendra aryabagus@undwi.ac.id

\section{PENDAHULUAN}

Selama setengah abad terakhir, perjuangan untuk keadilan menjadi semakin beragam dengan fokus pada upaya keadilan sosial, lingkungan dan rasial yang saling tumpang tindih dan saling memperkuat. Edward W. Soja dalam Seeking Spatial Justice, memperkenalkan keadilan spasial sebagai salah satu alternatif untuk mengkonseptualisasi keadilan. Soja mendokumentasikan dan mendukung 'perubahan spasial' menuju pemikiran tentang pentingnya ruang dalam membentuk dan mengkondisikan kehidupan manusia. (Nordquist, 2013).

Secara luas, keadilan spasial mengacu pada penekanan pada aspek keadilan dan ketidakadilan spasial. Sebagai langkah awal, diperlukan distribusi yang adil dan merata terkait sumber daya ruang yang memiliki nilai sosial ekonomi dan kesempatan untuk menggunakannya. Keadilan spasial bukan pengganti atau alternatif untuk bentuk keadilan sosial, ekonomi, atau lainnya melainkan cara melihat keadilan dari perspektif spasial. Dari sudut pandang ini, selalu ada dimensi spasial yang relevan untuk 
keadilan. Ketidakadilan spasial dapat dilihat sebagai hasil dan proses, dari pola distribusi dan eografis yang adil / tidak adil dan proses yang menghasilkan hasil dimaksud. Relatif mudah untuk menemukan contoh ketidakadilan spasial secara deskriptif, tetapi jauh lebih sulit untuk mengidentifikasi dan memahami proses yang mendasari menghasilkan ruang yang tidak adil. Pembangunan yang sempurna merata, kesetaraan sosial spasial komprehensif, keadilan distributif, serta hak asasi manusia universal tidak pernah dapat dicapai. Setiap wilayah di mana kita hidup memiliki beberapa tingkat ketidakadilan yang tertanam di dalamnya, sehingga perlu dilakukan intervensi untuk mewujudkan keadilan spasial. (Philippopoulos-Mihalopoulos, 2014; Soja, 2008).

Masalah-masalah tata guna lahan dan penataan ruang yang sering menimbulkan rasa ketidakadilan di masyarakat antara lain: konflik kepentingan antara masyarakat dan pemerintah terkait kawasan jalur hijau, meningkatnya alih fungsi lahan pertanian dan ketimpangan pembangunan antar daerah. Tulisan ini berupaya untuk menyumbang saran atas permasalahan tersebut dari perspektif perencanaan wilayah dan keadilan spasial, terutama berfokus pada konsep-konsep tata guna lahan/manajemen spasial. Melalui tulisan ini diharapkan menambah gagasan yang dapat diimplementasikan untuk mencapai keadilan sosial dalam tata guna lahan dan penataan ruang melalui keadilan spasial.

\section{PEMBAHASAN}

\subsection{Manajemen Spasial Jalur Hijau yang Berkeadilan Spasial}

Jalur hijau merupakan salah satu bentuk pemanfaatan Ruang Terbuka Hijau (RTH). Hal ini diatur dalam Penjelasan Pasal 29 Undang-Undang 26 Tahun 2007 tentang Penataan Ruang yang menyatakan bahwa "Ruang terbuka hijau publik merupakan ruang terbuka hijau yang dimiliki dan dikelola oleh pemerintah daerah kota yang digunakan untuk kepentingan masyarakat secara umum. 
Layan yang termasuk ruang terbuka hijau publik, antara lain, adalah taman kota, taman pemakaman umum, dan jalur hijau sepanjang jalan, sungai, dan pantai. Yang termasuk ruang terbuka hijau privat, antara lain, adalah kebun atau halaman rumah/gedung milik masyarakat/swasta yang ditanami tumbuhan”.

Tingginya tingkat pertumbuhan penduduk terutama akibat urbanisasi menyebabkan meningkatnya permintaan akan lahan untuk kebutuhan perumahan. Pemilik lahan yang lahannya ditetapkan sebagai jalur hijau oleh pemerintah daerah seringkali mengalami dilema dan rasa ketidakadilan, sebab lahannya sulit untuk dibangun bangunan dan memiliki nilai jual yang rendah, namun pemilik lahan masih tetap diwajibkan membayar pajak khususnya Pajak Bumi dan Bangunan. Demi memberi keadilan bagi pemilik lahan yang lahannya ditetapkan sebagai jalur hijau, pemerintah daerah dapat melakukan strategi kebijakan manajemen spasial, antara lain: Tax Deferral and Abatement Laws (TDAL), Use Value Property Taxation (UVPT), Property Tax Credit (PTC) dan Inheritance Tax Relief (ITR). Beberapa konsep kebijakan ini juga dapat diterapkan untuk lahan pertanian.

Tax Deferral and Abatement Laws (TDAL) atau secara harfiah berarti pengurangan dan penundaan pajak merupakan suatu perangkat kebijakan berupa pengecualian pembayaran Pajak Bumi dan Bangunan (PBB) berupa pengurangan jumlah terhitung yang harus dibayar atau penangguhan pembayaran pajak kepada pemilik lahan yang menjadi jalur hijau atau memiliki lahan pertanian. Pemerintah daerah memnerikan kompensasi finansial berupa perhitungan pajak berdasarkan nilai yang dihasilkan dari lahan tersebut (use-value based assessment) bukan pada estimasi harga pasar lahan tersebut (market-value based assessment) atau di Indonesia lebih dikenal dengan sebutan Nilai Jual Objek Pajak (NJOP). Selama pemilik lahan mempertahankan fungsi lahannya sebagai jalur hijau atau lahan pertanian, maka kompensasi finansial yang diterima berupa penaksiran pajak berdasarkan use-value 
based assessment, namun apabila pemilik lahan mengalihfungsikan lahannya maka besarnya pajak ditentukan berdasarkan marketvalue based assessment. Apabila terjadi transaksi jual beli atau diwariskan, maka pemilik baru akan memperoleh pengecualian perpajakan selama masih mempertahankan fungsi lahannya sebagai jalur hijau atau lahan pertanian (Widyawati Agustin \& Kubota, 2012; Yunus, 1990, 2005).

Use Value Property Taxation (UVPT) pada dasarnya adalah turunan dari Tax Deferral and Abatement Laws (TDAL). Kebijakan ini didasarkan pada penaksiran tarif pajak berdasarkan hasil yang diperoleh pemilik lahan atas pemanfaatan lahan yang dimiliki. Kebijakan ini didasarkan pada aspek psikologis yang muncul pada pemilik lahan. Apabila pemilik lahan mempertahankan fungsi lahannya sebagai jalur hijau atau lahan pertanian, maka besarny pajak yang harus dibayar dihitung berdasarkan hasil yang diperoleh dari pemanfaatan lahan, namun apabila terjadi alih fungsi lahan menjadi lahan budidaya non pertanian maka besarnya pajak yang harus dibayar pemilik lahan dihitung berdasarkan Nilai Jual Objek Pajak dari lahan tersebut (market-value property taxation). Melalui penerapan kebijakan ini, pemilik lahan dihadapkan pada dua pilihan membayar pajak lebih rendah atau lebih tinggi. Makin besar selisih antara use value property taxation dengan market-value property taxation, maka makin besar dampak psikologis yang dirasakan pemilik lahan, sehingga diharapkan pemilik lahan tetap mempertahankan fungsi lahan sebagai jalur hijau atau lahan pertanian (John E. Anderson, 1993; John E Anderson, 2012; John E Anderson et al., 2015; Yunus, 2005).

Property Tax Credit (PTC) pada hakikatnya memiliki kemiripan dengan Use Value Property Taxation, yaitu pemberian potongan pajak kepada pemilik lahan, hanya saja tidak ada kewajiban untuk menghitung besaran pajak berdasarkan use value property taxation atau market-value property taxation. 
Pengurangan pajak atas segala harta pemilik lahan didasarkan pada fakta bahwa pemilik lahan tersebut memiliki lahan yang berfungsi sebagai jalur hijau atau pertanian. Kebijakn ini dapat diprioritaskan pada wilayah yang memiliki perkembangan fisik yang pesat, sehingga perlu dimabil kebijakan dalam rangka mempertahankan jalur hijau atau lahan pertanian sebisa dan selama mungkin berdasarkan perjanjian yang dibuat pemilik lahan dan pemerintah daerah (J. E. Anderson \& Bunch, 1989; Yunus, 2005).

Inheritance Tax Relief (ITR) memiliki filosofi yang sama dengan UVPT, dimana penaksiran pajak dihitung berdasarkan hasil yang diperoleh dari pengelolaan lahan sebagai jalur hijau atau lahan pertanian. Penekanannya adalah pada unsur inheritance (warisan), sehingga yang menjadi subyeknya adalah pemilik baru yang memperoleh lahan sebagai warisan. Pemilik baru tetap memiliki hak yang sama untuk memperoleh kompensasi pajak selama pemilik baru tetap mempertahankan fungsi lahan sebagai jalur hijau atau lahan pertanian (OECD, 2020; Yunus, 2005).

\subsection{Manajemen Spasial Lahan Pertanian yang Berkeadilan Spasial}

Kementerian Pertanian (Kementan) menyebutkan sebanyak 60.000 hektare (ha) lahan pertanian di Indonesia menyusut setiap tahunnya. Penyusutan tersebut disebabkan oleh alih fungsi lahan menjadi area nonpertanian. Berdasarkan keterangan Kementan, alih fungsi tersebut dilakukan untuk proyek pembangunan jangka panjang seperti kompleks perumahan, pembangunan pabrik, fasilitas jalan tol hingga fasilitas umum fisik lainnya (Dedy Darmawan Nasution, 2020). Faktor lain yang menyebabkan menyusutnya lahan pertanian adalah usaha pertanian cenderung mengalami kerugian, dan gangguan-gangguan lain seperti gangguan pengairan karena bangunan-bangunan baru, sempitnya lahan pertanian sehingga produksi pertanian tidak optimal mendatangkan keuntungan bagi petani, serta harga lahan 
yang semakin meningkat menjadi faktor determinan mengapa petani meninggalkan usaha pertanian (Yunus, 2005). Sebagai upaya untuk mempertahankan lahan pertanian dan memberi keadilan spasial bagi petani maka dapat dilakukan beberapa strategi manajemen spasial, antara lain: Agricultural Zoning (AZ), Provincial Police Power (PPP), Integrated Provincial-State Program (IPSP) dan Agricultural Districting (AD).

Agricultural Zoning (AZ) merupakan suatu kebijakan yang merumuskan wilayah tertentu terkait bentuk pemanfaatan lahan yang harus direalisasikan. Pelanggaran hukum atau sanksi atas kebijakan ini mempunyai konsekuensi hukum sesuai peraturan yang berlaku. Melalui kebijakan ini bentuk-bentuk pemanfaatan lahan pertanian mendapat prioritas yang tinggi. Selain penetapan suatu wilayah sebagai Agricultural Zoning kebijakan ini juga harus diikuti dengan kebijakan insentif finansial tertentu yang dapat diterima pemillik lahan yang terkena zoning, seperti kemudahan memperoleh pupuk, bibit unggul, bantuan tenaga ahli yang memberi bantuan penyuluhan untuk meningkatkan produksi pertanian, bantuan pemasaran hasil-hasil pertanian dan lain sebagainya, termasuk keringanan pajak seperti yang telah diuraikan di atas (Boonyanam, 2019; Bryant, 2017; Perrin et al., 2020; Yunus, 2005).

Provincial Police Power (PPP) menekankan bahwa pemerintah kabupaten/kota harus dengan tegas mengikuti rencana tata ruang yang telah ditetapkan pemerintah provinsi terkait dengan kahan pertanian. Pelanggaran terhadap kebijakan rencana tata ruang provinsi akan memperoleh sanksi. Penataan ruang pada level pemerintahan bawah harus selalu mangacu pada formulasi penataan ruang pada level pemerintahan di atasnya (Yunus, 2005).

Integrated Provincial-State Program (IPSP) menekankan pada sinkronisasi pembangunan spasial dari tingkat pemerintahan paling atas sampai bawah. Formulasi kebijakan spasial tingkat pusat harus digunakan sebagai panduan oleh level pemerintahan 
regional dan lokal. Berdasarkan pengalaman pada beberapa negara hal ini ternyata tidak diikuti secara konsisten sehingga menimbulkan permasalahan lingkungan yang sulit dipecahkan kemudian hari. IPSP dalam pelaksanaanya dapat bersifat keharusan atau wajib namun dapat juga bersifat sukarela. Kebijakan yang bersifat keharusan, setiap pemerintah lokal wajib mencegah konversi lahan dari lahan pertanian menjadi nonpertanian, jika terjadi pelanggaran maka harus dikenakan sanksi yang tegas. Kebijakan IPSP yang bersifat sukarela, pemerintah menawarkan sejumlah keuntungan finansial bagi pemilik lahan apabila mereka bersedia ikut serta dalam IPSP, sehingga dengan sendirinya pemilik lahan harus mematuhi semua peraturan dalam IPSP (Yunus, 1990, 2005).

Agricultural Districting (AD) hampir mirip dengan IPSP yang bersifat sukarela, bedanya adalah pada IPSP inisiatif datang dari pemerintah dengan cara menawarkan kepada pemilik lahan untuk mengikuti program, sedangkan pada AD inisiatif datang dari pemilik lahan untuk mengikuti program preservasi lahan pertanian. Wilayah yang disetujui masuk ke dalam program AD harus memenuhi luasan minimal yang ditentukan dengan lokasi yang menyatu serta periode waktu minimal dalam program AD. Sebagaimana dengan program yang lain, pemerintah menghargai itikad baik pemilik lahan dengan memberikan insentif finansial kepada pemilik lahan. Oleh karena yang mengusulkan adalah kelompok pemilik lahan pada blok yang sama, maka insentif finansial yang diterima sesuai dengan apa yang diusulkan berdasarkan kesamaan kebutuhan pada bagian wilayah pertanian yang bersangkutan. Partisipan program AD juga terikat dengan peraturan yang berkaitan dengan preservasi lahan pertanian sampai dengan jangka waktu tertentu yang telah ditetapkan. Landasan filosofis program AD ini adalah menumbuhkan kesadaran pemilik lahan pertanian dalam membantu pemerintah dalam upaya preservasi lahan pertanian (Yunus, 1990, 2005). 


\subsection{Tata Ruang yang Berkeadilan Spasial untuk Mengatasi Ketimpangan Pembangunan Antar Wilayah}

Pembangunan merupakan proses multidimensi yang bertujuan menciptakan perubahan mendasar bagi kehidupan masyarakat ke arah yang lebih baik. Akan tetapi, pembangunan tidak selalu menghasilkan pemerataan bagi setiap wilayah. Ketimpangan merupakan sebuah fenomena yang akan selalu membayangi proses pembangunan wilayah (Fauzi, 2019). Ketimpangan wilayah timbul karena tidak adanya pemerataan dalam pembangunan ekonomi yang disebabkan karena adanya perbedaan antarwilayah satu dengan lainnya atau antara deasa dan kota. Pertumbuhan ekonomi yang meningkat di suatu daerah akan tetapi tidak diikuti oleh peningkatan pertumbuhan ekonomi di daerah lain maka akan menyebabkan ketimpangan pembangunan menjadi semakin tinggi (Darmawan \& Tukiman, 2020). Untuk mengatasi ketimpangan pembangunan secara keruangan atau spasial dapat dilakukan beberapa hal sehingga terjadi keadilan spasial, antara lain Equity Planning, Development Moratoria (DA), Rurban Oriented Paradigm (ROP), dan Planned Unit Development (PUD).

Salah satu upaya untuk mewujudkan keadilan spasial adalah dengan meredistribusi sumber daya keruangan bagi kelompok masyarakat yang terdampak negatif dan/atau tidak terdampak sama sekali oleh penataan ruang. Hal ini dapat tercapai melalui salah satu konsep perencanaan ruang yaitu equity planning. Equity planning adalah kerangka kerja di mana perencana kota yang bekerja di dalam pemerintahan menggunakan keterampilan penelitian, analitis, dan pengorganisasian mereka untuk mempengaruhi pendapat, memobilisasi konstituen yang kurang terwakili, dan memajukan dan mungkin menerapkan kebijakan dan program yang mendistribusikan kembali sumber daya publik dan swasta kepada masyarakat marjinal. (Metzger, 1996). 
Equity planning, terinspirasi dari perencanaan advokasi yang dikem ukakan Davidoff. Equity planning mengikuti pendapat perencanaan advokasi bahwa akar - akar ketidakadilan sosial ekonomis perkotaan perlu diatasi, tapi tidak sependapat bahwa perencana mempunyai tanggung jawab eksplisit untuk membantu pihak - pihak yang tidak beruntung. Equity planning berusaha untuk mencapai redistribusi kekuasaan, sumber daya atau partisipasi yang semula berpusat pada elit lokal menuju pada penduduk dan wilayah yang termarjinalkan (Wijaatmaja, 2015)

Pembangunan spasial diarahkan menuju desentralisasi sistem pusat kegiatan dari yang tadinya berpusat pada kota-kota besar disebar ke arah pembangunan kota-kota kecil di wilayah perdesaan sebagai pusat kegiatan di luar usaha tani dan jasa-jasa pelayanan. Ekonomi kota-kota besar di masa datang tidak akan mengalami pertumbuhan lagi, sebab perkembangan masif kota-kota telah menimbulkan biaya sosial tinggi yang mengarah pada inefisiensi dan menghambat pertumbuhan ekonomi disamping menghambat pemerataan pembangunan wilayah (equity), sehingga tidak mengarah ke pembangunan berkelanjutan (sustainable development). Perencanaan pembangunan diarahkan kepada terjadinya pemerataan (equity), pertumbuhan (eficiency), dan keberlanjutan (sustainability) dalam pembangunan ekonomi. Paradigma baru pembangunan ini dapat mengacu kepada apa yang disebut dalil kedua fundamental ekonomi kesejahteraan (The second fundamental of welfare economics), dimana dalil ini menyatakan bahwa sebenarnya pemerintah dapat memilih target pemerataan ekonomi yang diinginkan melalui transfer, perpajakan dan subsidi, sedangkan aspek ekonomi selebihnya dapat lebih diserahkan kepada mekanisme pasar (Rustiadi, 2001).

Equity Planning secara teknis spasial dapat diimplementasikan dengan program Development Moratoria (DA) pada wilayah yang mengalami perkembangan terlalu pesat dan 
diikuti dengan distribusi sumber daya keruangan pada daerah yang tertinggal pembangunannya. Moratoria (jamak) /moratorium (tunggal) berarti penangguhan suatu aktivitas secara resmi. DA bertujuan 1) menghambat/menangguhkan laju perkembangan suatu wilayah agar menjadi lebih lambat dan 2) menyetop laju perkembangan suatu wilayah pada titik-titik tertentu. Saat suatu wilayah dirasa sudah dianggap perlu untuk berkembang lebih lanjut, maka moratorium dapat dicabut sewaktu-waktu. Bentukbentuk kebijakan untuk memperlambat laju perkembangan adalah melarang segala bentuk konversi lahan dari bentuk lahan pertanian menjadi non-pertanian. Teknik-teknik yang dapat dilakukan di lapangan untuk mengimplementasikan DA, antara lain: 1) tidak mengizinkan pembangunan selokan pembuangan limbah baru, 2) tidak mengizinkan penyambungan baru dengan sistem pembuangan limbah lingkungan, 3) tidak mengeluarkan izin mendirikan bangunan, 4) tidak mengizinkan penyambungan pipa air bersih, dan jaringan listrik baru, dan 5) tidak mengizinkan bentuk pembangunan fisik baru. Teknik-teknik tersebut diprioritaskan selain untuk daerah yang sudah terlalu pesat pembangunannya juga bisa diterapkan untuk lahan pertanian untuk preservasi lahan pertanian (Yunus, 1990, 2005).

Rurban Oriented Paradigm (ROP) adalah suatu paradigma pembangunan kota yang dilandasi filosofi bahwa pembangunan kota bukan hanya untuk kota itu sendiri. Hal ini didasari pada kenyataan bahwa suatu kota biasanya dikelilingi pedesaan yang memiliki lahan pertanian. Pembangunan kota dipandang sebagai bagian integral dalam sistem pembangunan nasional yang tidak dapat diisolasi dari pembangunan sektor lain khususnya sektor rural/pedesaan. Pembangunan kota tidak dapat hanya mementingkan daerah sendiri saja, karena akan menimbulkan kesenjangan pembangunan desa dan kota. Kemiskinan di daerah perdesaan dapat menjadi faktor pendorong utama penduduk perdesaan berbondong-bondong bermigrasi ke kota, sehingga 
menimbulkan urbanisasi yang berdampak negatif bagi kota itu sendiri (Yunus, 2005).

Paradigma ini dapat dimplementasikan dengan teknik manajemen spasial, antara lain Model Perancangan Kota dengan Kota-Kota Satelit dan Pusat-pusat Permukiman Baru. Model perancangan ini merupakan integrasi kota utama dengan kota-kota kecil atau perdesaan dan pusat-pusat permukiman baru yang dibangun. Kota-kota kecil dan desa-desa ini berperan sebagai kota satelit yang bersinergi dengan kota besar dalam kegiatan ekonomi dan sementara itu pembangunan pusat permukiman baru akan mendukung keberadaan kota besar dalam hal sosial ekonomi. Kota satelit ini tidak bergantung sepenuhnya pada kota besar secara ekonomi, namun masih tergantung dalam beberapa hal dengan kota satelit, seperti pengadaan barang dan jasa, namun dalam kota satelit ini telah mampu berkembang fungsi-fungsi kota yang mampu memberikan lapangan pekerjaan bagi penduduknya, sehingga dapat mengurangi urbanisasi. Oleh karena beberapa kota kecil dan desa di sekitar kota utama tidak seluruhnnya mampu menjadi kota satelit maka perancangan kota yang dirumuskan hendaknya juga memberdayakan kota-kota tersebut agar mampu menjadi katalisator bagi daerah-daerah lain disekitarnya. Jalur-jalur transportasi antar kota dan desa harus dibangun dengan baik, sehingga sinergi sosial ekonomi dapat terwujud (Yunus, 2005).

Model lain yang dapat diterapkan adalah Model Perancangan Kota Stellar atau Radial. Model ini sebenarnya hampir mirip dengan model perancangan kota dengan kota-kota satelit. Perbedaannya adalah pada Model Perancangan Kota Stellar atau Radial, terdapat pusat kegiatan utama yang ditandai dengan primary business district, namun di beberapa bagian luar kotanya juga berkembang secondary business district yang lokasinya relatif dekat dan tidak sejauh kota-kota satelit. Model perancangan ini memerlukan kebijakan pembangunan koridor antara primary business district dengan secondary business district sehingga 
bentuk spasialnya dapat dipadankan dengan stellar. Pada awalnya akan terbentuk sebuah kota benbentuk bintang yang ujungujungnya runcing, namun pada perkembangan selanjutnya ujungujugn runcing bintang menyatu secara fisik dengan pusat-pusat kegiatan sekunder sehingga menciptakan bentuk stelar yang juga ditandai oleh corridor development di sepanjang jari-jari radial transportasi (Yunus, 2005).

Planned Unit Development (PUD) merupakan alat untuk mengacu pada perkembangan wilayah yang dianggap belum mampu berkembang secepat wilayah lain. Wilayah yang direncanakan ini dirancang dengan seksama sehingga memiliki tata bangunan yang jelas dan biasanya untuk kompleks peruntukan pemanfaatan lahan tertentu (misalnya pembangunan kompleks kampus perguruan tinggi, kompleks perkantoran pemerintah, kompleks wisata terpadu, kompleks bandar udara dan lainnya). Pengelompokan bangunan-bangunan sejenis dalam ukuran, dalam hal arsitektur dan keberadaan ruang terbuka hijau untuk kepentingan bersama dirancang sedemikian rupa sehingga daerah yang bersangkutan menjadi suatu kesatuan pengembangan. Teknik ini memiliki tiga krakteristik utama, yaitu: (1) teknik ini pada umumnya meliputi wilayah yang relatif luas seperti kompleks kampus perguruan tinggi sampai perancangan kota baru; (2) teknik ini bertujuan untuk menciptakan komposisi bangunan dan tipe pemanfaatan lahan tertentu; (3) teknik ini akan mengakomodasi pembangunan yang dilaksanakan secara bertahap (Yunus, 2005).

\section{PENUTUP}

Pembangunan adalah sebuah proses multidimensi yang berusaha untuk meningkatkan taraf hidup masyarakat, namun pembangunan tidak menjamin distribusi hasil-hasil pembangunan secara merata, sehingga diperlukan suatu upaya agar semua lapisan masyarakat dapat menikmati hasil-hasil pembangunan. Distribusi 
pembangunan yang tidak merata terjadi salah satunya karena tidak terwujudnya keadilan spasial (keruangan) dalam perencanaan pembangunan, baik itu tata ruang dan tata guna lahan. Keadilan spasial merupakan sebuah gagasam baru yang mencoba untuk mengkonseptualisasikan keadilan, namun bukanlah sebuah alternatif atau pengganti konsep keadilan yang telah ada.

Mewujudkan keadilan spasial dapat diwujudkan melalui teknik-teknik manajemen spasial yang berkeadilan. Ketidakadilan bagi pemilik lahan yang lahannya masuk area jalur hijau dapat ditanggulangi dengan beberapa teknik manajemen spasial seperti Tax Deferral and Abatement Laws (TDAL), Use Value Property Taxation (UVPT), Property Tax Credit (PTC) dan Inheritance Tax Relief (ITR). Teknik-teknik ini pada hakikatnya memberikan insentif finansial kepada pemilik lahan berupa keringanan dan penangguhan pajak, sebagai bentuk apresiasi pemerintah atas kesediaan pemilik lahan yang tidak mengalihfungsikan lahannya dari jalur hijau menjadi fungsi lain.

Manajemen spasial untuk lahan pertanian dapat dilakukan dengan Agricultural Zoning (AZ), Provincial Police Power (PPP), Integrated Provincial-State Program (IPSP) dan Agricultural Districting $(A D)$. Teknik-teknik majanemen spasial untuk lahan pertanian ini pada hakikatnya membentuk zona khusus pertanian baik secara wajib maupun sukarela, termasuk dengan kemudahankemudahan finansial dan sarana-prasarana produksi pertanian sehingga dapat terwujudnya preservasi lahan pertanian sekaligus memberi keadilan dan apresiasi kepada petani yang telah bersedia mempertahankan lahan dan usaha pertaniannya.

Kesenjangan pembangunan antar wilayah, baik kesenjangan antara desa dan kota dapat diatasi dengan Equity Planning, Development Moratoria (DA), Rurban Oriented Paradigm (ROP), dan Planned Unit Development (PUD). Perencanaan sedapat mungkin dilakukan dengan cara meredistribusi sumber daya keruangan dan pembangunan pada 
daerah-daerah yang pertumbuhan ekonominya relatif lambat. Hal ini dapat dilakukan dengan moratorium pembangunan pada suatu wilayah yang pertumbuhannya sangat pesat dan mengalihkan sumber daya pembangunan untuk daerah lain yang pertumbuhannya kurang pesat. Pemerataan untuk mewujudkan keadilan spasial dapat juga dilakukan dengan cara pembangunan berbasis kota-desa yang terintegrasi sehingga tercipta sinergi antara desa dan kota baik secara sosial maupun ekonomi. Pembangunan infrastruktur atau sarana berupa kompleks pembangunan besar dengan fungsi tertentu dapat juga diterapkan pada daerah yang pertumbuhannya relatif lambat sebagai katalisator untuk meningkatkan pertumbuhan dan perkembangan ekonomi wilayah.

\section{DAFTAR PUSTAKA}

Adi, S. W. (2020, October). Peluang \& Tantangan Generasi

Milenial Dalam Menghadapi Era Society 5.0. Jawa Pos Radar Solo.

Anderson, J. E., \& Bunch, H. C. (1989). Agricultural property tax relief: tax credits, tax rates, and land values. Land Economics, 65(1), 13-22. https://doi.org/10.2307/3146259

Anderson, John E. (1993). Use-Value Property Tax Assessment:

Effects on Land Development. Land Economics, 69(3), 263. https://doi.org/10.2307/3146592

Anderson, John E. (2012). Agricultural Use-Value Property Tax

Assessment: Estimation and Policy Issues.

https://doi.org/10.1111/j.1540-5850.2012.01025.x

Anderson, John E, Giertz, S. H., Shimul, S. N., \& Family, B.

(2015). Property Taxes for Agriculture Use-Value Assessment and Urbanization across the United States.

Assingkily, M. S., Putro, K. Z., \& Sirait, S. (2019). Kearifan

Menyikapi Anak Usia Dasar di Era Generasi Alpha (Ditinjau dari Perspektif Fenomenologi). Attadib: Journal of

Elementary Education, 3(2), 1-21. 
Boonyanam, N. (2019). Agricultural Zoning and Policy Conflict:

Thailand's Experience. In Land Use - Assessing the Past,

Envisioning the Future. IntechOpen.

https://doi.org/10.5772/intechopen.80262

BPIP. (2020). Cara Mudah Menanamkan Nilai-nilai Pancasila

Pada Anak Sejak Kecil. Bpip.Go.Id.

Bryant, C. (2017). What Can Agricultural Land Use Planning

Contribute to Food Production and Food Policy? International

International Journal of Avian \& Wildlife Biology, 2(1).

https://doi.org/10.15406/ijawb.2017.02.00009

Darmawan, M. J., \& Tukiman, T. (2020). ANALISIS DIMENSI

KETIMPANGAN PEMBANGUNAN ANTAR WILAYAH

DI PROVINSI JAWA TIMUR TAHUN 2014-2018.

Dinamika Governance : Jurnal Ilmu Administrasi Negara,

10(1). https://doi.org/10.33005/jdg.v10i1.2045

Dedy Darmawan Nasution. (2020). Tiap Tahun, 60 Ribu Hektare

Lahan Pertanian Menyusut | Republika Online.

Dewantara, J. A., Suhendar, I. F., Rosyid, R., \& Atmaja, T. S.

(2019). Pancasila as Ideology and Characteristics Civic

Education in Indonesia. International Journal for Educational

and Vocational Studies, 1(5), 400-405.

https://doi.org/10.29103/ijevs.v1i5.1617

Endah Wulantina, S. M. (2019). Persepsi Peserta Didik terhadap

Metode Blended Learning dengan Google Classroom. Jurnal

Inovasi Matematika, 1(2), 110-121.

https://doi.org/10.35438/inomatika.v1i2.156

Fajarini, U. (2014). Peranan Kearifan Lokal Dalam Pendidikan

Karakter. SOSIO DIDAKTIKA: Social Science Education

Journal, 1(2). https://doi.org/10.15408/sd.v1i2.1225

Fauzi, M. R. (2019). Ketimpangan, Pola Spasial, dan Kinerja

Pembangunan Wilayah di Provinsi Jawa Timur. Journal of

Regional and Rural Development Planning (Jurnal

Perencanaan Pembangunan Wilayah Dan Perdesaan- 
JP2WD), 2019(3), 157-171.

https://doi.org/10.29244/jp2wd.2019.3.3.157-171

Febriansyah, F. I. (2017). Keadilan Berdasarkan Pancasila Sebagai

Dasar Filosofis Dan Ideologis Bangsa. DiH: Jurnal Ilmu

Hukum, 13(25), 1. https://doi.org/10.30996/dih.v13i25.1545

Fitriarti, E. A. (2019). Urgensi Literasi Digital Dalam Menangkal

Hoax Informasi Kesehatan Di Era Digital.

Metacommunication: Journal of Communication Studies, 4(2),

219. https://doi.org/10.20527/mc.v4i2.6929

Haryanti, R. (2019, January). "Society 5.0", Solusi Jepang Atasi

Defisit Penduduk dan Infrastruktur. Kompas.Com.

Hidayatullah, R. (2020). Pendidikan Musik: Pendekatan Musik

Untuk Anak di Era 4.0. CV. Rumah Kayu Pustaka Utama.

Irwansyah, R., Darmayani, S., Mastikawati, M., Saputro, A. N. C.,

Wihartanti, L. V., Fauzi, A., Arifudin, O., Purandina, I. P. Y.,

Latifah, E. D., Septiyani, T., Pangestika, R. R., Fatayah, F.,

Ayuningtyas, P., Lemba, V. C., \& Hartono, R. (2021).

PERKEMBANGAN PESERTA DIDIK . In Widina Bhakti

Persada Bandung. Widina Bhakti Persada Bandung.

Metzger, J. T. (1996). The Theory and Practice of Equity Planning:

An Annotated Bibliography. Journal of Planning Literature,

11(1), 112-126. https://doi.org/10.1177/088541229601100106

Mustofa, M. I., Chodzirin, M., Sayekti, L., \& Fauzan, R. (2019).

Formulasi Model Perkuliahan Daring Sebagai Upaya

Menekan Disparitas Kualitas Perguruan Tinggi. Walisongo

Journal of Information Technology, 1(2), 151.

https://doi.org/10.21580/wjit.2019.1.2.4067

Nordquist, M. (2013). Seeking spatial justice by Edward W. Soja.

Contemporary Political Theory, 12(1), e16-e18.

https://doi.org/10.1057/cpt.2011.40

OECD. (2020). Taxation in Agriculture. In Taxation in Agriculture.

OECD. https://doi.org/10.1787/073bdf99-en

Perrin, C., Clément, C., Melot, R., \& Nougarèdes, B. (2020). land 
Preserving Farmland on the Urban Fringe: A Literature Review on Land Policies in Developed Countries.

https://doi.org/10.3390/land9070223

Philippopoulos-Mihalopoulos, A. (2014). The Movement of Spatial Justice. MONDI MIGRANTI, 1, 7-19.

https://doi.org/10.3280/mm2014-001001

Relman, E. (2020). Business insider Singapore.

Rustiadi, E. (2001). Pergeseran Menuju Paradigma Baru

Pengembangan Wilayah. Forum Diskusi Pengembangan

Metode, Puslitbang Ketenagakerjaan Dan Ketransmigrasian,

Departemen Tenagakerja Dan Transmigrasi.

Septiawan, Y., Purandina, I. P. Y., Jumari, Tafonao, T., Ramlan, A.

M., Dewi, N. P. C. P., Tambuanan, T. S., Zaedun, N., Arlotas,

R. K., Suryaningwidi, R., \& Muvid, M. B. (2020). Strategi

dan Metode Pembelajaran Era Society 5.0 di Perguruan

Tinggi (Y. Septiawan \& M. B. Muvid (eds.)). Goresan Pena.

Setiyani, S., Dasilah, \& Nurcahyo, D. N. (2020). Paradigma Baru

Pendidikan Era Disruptif Menuju Masyarakat 5.0. Prosiding

Seminar Nasional Pendidikan Program Pascasarjana

Universitas Pgri Palembang 10 Januari 2020, 747-756.

Soja, E. W. (2008, March). The city and spatial justice. Spatial Justice.

Sunoto. (1984). Mengenal Filsafat Pancasila: Pendekatan melalui metafisika logika etika. Hanindita.

Suparman. (2012). Pancasila. Balai Pustaka.

Widyawati Agustin, I., \& Kubota, H. (2012). Changing Physic,

Changing Pattern, and Conflicts of Rural-Urban Fringe Using a Combination Model. J. Basic. Appl. Sci. Res, 2(12), 1272212730.

Wijaatmaja, A. B. M. (2015). PENDEKATAN PERENCANAAN

TATA RUANG WILAYAH DI KOTA DENPASAR - PDF Free

Download. Program Pascasarjana Universitas Udayana.

Yuliana. (2020). Corona virus diseases (Covid -19); Sebuah 
tinjauan literatur. Wellness and Healthy Magazine, 2(1), 187192.

Yunus, H. S. (1990). Searching new strategies for managing and controlling urban land growth: a preliminary outlook on Indonesia. Indonesian Journal of Geography, 20(60), 1-10. https://doi.org/10.22146/IJG.2188

Yunus, H. S. (2005). Manajemen kota : perspektif spasial. 


\section{PEMANFAATAN GOOGLE GLASSROOMUNTUK MEMFASILITASI SELF-REGULATED LEARNIIG DALAM PEMBELAJARAN JARAK JAUH DI MASA PANDEMI GOVID-19}

\section{Gede Sutrisna}

Fakultas Keguruan dan Ilmu Pendidikan Universitas Dwijendra gedesutrisna@undwi.ac.id

\section{PENDAHULUAN}

Merebaknya Pandemi Covid-19 secara global berujung pada transformasi besar-besaran yang dilakukan pada berbagai aspek kehidupan manusia tanpa terkecuali pada bidang pendidikan. Di negara kita sendiri, Indonesia, seluruh kegiatan akademik termasuk kegiatan belajar mengajar (KBM) di tingkat sekolah dasar sampai perguruan tinggi yang dulunya dilakukan secara tatap muka beralih menjadi Belajar dari Rumah. Penerapan kegiatan Belajar dari Rumah ini merupakan bentuk tindak lanjut dari kebijakan yang dikeluarkan oleh Menteri Pendidikan dan Kebudayaan Republik Indonesia melalui Surat Edaran Nomor Nomor 36962/MPK.A/HK/2020 tentang Pembelajaran secara Daring dan Bekerja dari Rumah dalam Rangka Pencegahan Penyebaran Corona Virus Disease (Covid-19). 
Dengan diberlakukannya kebijakan tersebut, tenaga pengajar baik guru maupun dosen dituntut untuk lebih kreatif dan inovatif dalam memanfaatkan teknologi dengan tujuan agar peserta didik tetap memperoleh hak belajar mereka selama masa Belajar dari Rumah. Melalui gawai yang terkoneksi dengan internet, para guru dan dosen pun bisa terhubung dan berkomunikasi dengan peserta didiknya secara daring (online). Namun, tentu kedua elemen teknologi tersebut belum bisa memaksimalkan kegiatan belajar mengajar, tanpa adanya dukungan dari aplikasi dan atau platform digital. Salah satu jenis aplikasi yang booming di kalangan pendidik pada awal masa tersebut adalah aplikasi video conference. Aplikasi ini memungkinkan para guru, dosen dan siswa bertemu satu sama lain dalam 1 (satu) ruang virtual. Selanjutnya, materi pembelajaran dijelaskan layaknya kelas tatap muka. Terdapatnya diskusi dan interaksi yang terjadi secara live menjadi poin paling penting dalam penggunaan aplikasi ini. Sebagai contoh, ketika peserta didik tidak paham terhadap suatu materi maka mereka dapat bertanya langsung kepada pengajarnya. Hal inilah yang membuatnya hampir mirip dengan proses pembelajaran yang dilakukan dengan tatap muka langsung (Silviari, 2020).

Walaupun demikian, penggunaan video conference dirasa masih belum cukup efektif untuk memfasilitasi keseluruhan proses pembelajaran yang kompleks. Muncul anggapan dimana penggunaan sistem ini cenderung bersifat teacher-centered yang mengalami proses digitalisasi. Hal ini tentunya tidak relevan dengan sistem pembelajaran abad ke-21 yang lebih menekankan pada pembelajaran yang terpusat pada siswa (student-centered) (Sutrisna \& Juliari, 2019; Sutrisna \& Artini, 2020). Disinilah Learning Management System (LMS) dipandang sebagai all in one alternatif yang mampu memfasilitasi keseluruhan proses pembelajaran yang bersifat daring (online), mulai dari penyediaan materi pembelajaran, penugasan termasuk evaluasi hasil belajar. Sistem ini juga menyediakan ruang bagi mahasiswa untuk 
berdiskusi secara virtual sehingga pendidik bisa memonitoring partisipasi peserta didik dalam pembelajaran. Dengan segala manfaat yang dimilikinya, penggunaan LMS diharapkan mampu memupuk kemandirian peserta didik untuk belajar secara mandiri (self-regulated learning) walaupun proses pembelajaran tidak dapat dilaksanakan secara langsung (Ma'arif \& Murdiono, 2021).

Dari beberapa LMS yang ada, salah satu LMS yang paling banyak digunakan saat ini adalah Google Classroom. Tampilannya yang sederhana (user friendly) membuat LMS yang dikembangkan oleh Google ini dapat dioperasikan dengan mudah oleh pengajar dan peserta didik. Selain itu, Google Classroom juga dibekali dengan sejumlah fitur yang terintegrasi dengan aplikasi-aplikasi buatan Google lainnya sehingga memudahkan pengajar untuk mengoptimalisasi dan mengelola kompleksitas pembelajaran daring.

\section{PEMBAHASAN}

\subsection{Google Classroom, Kelas Digital untuk Pembelajaran Daring}

Google Classroom adalah aplikasi Learning Management System (LMS) berbasis internet yang dikembangkan oleh Google, salah satu perusahaan teknologi terbesear di dunia. Aplikasi Google Classroom tersedia pada berbagai platform seperti Windows, Android dan iOs yang dapat digunakan secara gratis. Oleh sebab itu, baik pengajar maupun peserta didik bisa mengaksesnya melalui komputer PC, laptop bahkan smartphone cukup dengan menggunakan akun Google tanpa harus mengeluarkan biaya sepeserpun (Rahmatunnisa, 2020).

Dengan fungsi sebagai kelas digital, Google Classroom dirancang untuk memfasilitasi seluruh proses pembelajaran mencakup distribusi bahan ajar, penugasan serta evaluasi hasil pembelajaran. Secara teknis, pengajar perlu melalukan serangkaian 
persiapan agar LMS ini dapat digunakan secara maksimal. Hal pertama yang dilakukan adalah pembuatan kelas sesuai dengan mata pelajaran / mata kuliah yang diampu. Selanjutnya, siswa dapat diundang untuk bergabung kedalam kelas tersebut melalui kode kelas yang dibagikan oleh pengajar. Setelah memastikan semua siswa sudah bergabung di kelas tersebut, pengajar sudah dapat menggunakannya untuk menunjang proses pembelajaran, seperti memberikan pengumuman, membagikan materi pembelajaran serta memberikan penugasan. Layaknya portofolio, Google Classroom secara otomatis membuat folder penyimpanan untuk setiap bentuk penugasan yang tersimpan dan terorganisir dengan baik pada Google Drive. Hal ini memungkinkan pengajar memonitoring siapa saja yang sudah atau belum menyelesaikan tugas, memberikan umpan balik serta penilaian langsung terhadap hasil pekerjaan masing-masing peserta didik (Durahman, 2018).

\subsection{Fitur - Fitur Google Classroom}

Berikut ini fitur-fitur yang terdapat dalam Google Classroom yang bisa dimaksimalkan secara efektif untuk menunjang pembelajaran daring (Hapsari \& Pamungkas, 2019).

- Create Material

Fitur ini digunakan untuk membagikan materi pembelajaran dalam berbagai format, seperti word, power point, pdf, video, audio dan bentuk file lainnya. Setelah materinya diunggah oleh pengajar, akan muncul pemberitahuan baik di beranda kelas maupun perangkat siswa. Selanjutnya, materi tersebut dapat dibuka dan diunduh oleh peserta didik untuk dipelajari.

- Create Topic

Fitur ini dapat digunakan untuk membuat ataupun melabeli topik bahasan dari materi pembelajaran yang akan dibahas di kelas virtual. Fitur ini memudahkan peserta didik untuk mengetahui dan mempersiapkan segala sesuatu yang 
berhubungan dengan topik yang akan dibahas sehingga mereka bisa berpartisipasi secara aktif dalam diskusi kelas.

- Create Question

Fitur ini dapat digunakan untuk memberikan pertanyaan kepada peserta didik. Fitur ini cocok digunakan sebagai stimulus agar peserta didik terlibat aktif dalam berdiskusi. Agar lebih maksimal, pengajar juga dapat mengaktifkan opsi "students can reply to each other" untuk memungkinkan peserta saling berbagi pendapat atau tanya jawab dalam kelas.

- Create Assignment

Fitur ini dapat digunakan oleh pengajar untuk memberikan tugas kepada peserta didik. Melalui fitur ini, pengajar dapat menuliskan instruksi dan petunjuk yang memberikan gambaran terkait apa saja yang perlu dilakukan oleh peserta didik untuk menyelesaikan tugas yang diberikan. Serupa dengan saat membagikan materi pembelajaran, pada fitur ini pengajar dapat melampirkan berkas/dokumen dengan berbagi macam format sebagai bahan untuk tugas. Selain itu, pengajar dapat mengatur batas waktu (hari dan jam) pengumpulan tugas. Hal ini dilakukan untuk memupuk sikap disiplin belajar peserta didik, dan mencegah mereka mengumpulkan tugas seenaknya kapanpun mereka mau.

- Create Quiz Assignment

Fitur ini dapat digunakan untuk memberikan quiz. Pada praktiknya, terutama ditengah situasi pandemi ini, sebagian besar pengajar tidak hanya memanfaatkan fitur ini untuk memberikan quiz, tapi juga sebagai instrument untuk melaksanakan test seperti Ulangan Harian, Ulangan Tengah Semester, Ulangan Akhir Semester bahkan Ujian. Saat memilih untuk menggunakan fitur ini, Google Form akan langsung muncul secara otomatis yang selanjutnya bisa diedit untuk ditambahkan butir-butir pertanyaan, dan 
nantinya digunakan sebagai online test. Yang paling penting adalah fitur ini juga berguna untuk menghemat kertas karena test dilaksanakan secara daring.

- Reuse Post

Fitur ini memungkinkan pengajar menggunakan kembali kiriman (postingan) yang telah ada sebelumnya. Berkat fitur ini, pengajar bisa menghemat waktunya dan tidak perlu repot-repot membuat semuanya dari awal. Jika diperlukan, pengajar dapat mengedit dan memperbaharui kontennya sebelum digunakan kembali. Selanjutnya dapat langsung dibagikan ke kelas yang dikehendaki.

- Grading (Penilaian)

Terdapat beberapa metode penilaian yang dapat digunakan pada Google Classroom dalam mengevaluasi hasil pekerjaan peserta didik. Penilaian dapat dilaksanakan dengan langsung menginputkan nilai terhadap hasil pekerjaan peserta didik, atau dapat juga melalui rubrik penilaian yang dilengkapi dengan indikator - indikator khusus yang bisa dibuat langsung pada Google Classroom. Dalam praktiknya, penilaian terhadap hasil pekerjaan/tugas peserta didik yang dikumpulkan pada Google Classroom dapat dilakukan secara real time. Hasil kerja yang telah dikumpulkan tersebut, selanjutnya dicek, diberikan komentar/umpan balik serta dinilai oleh pengajar. Tugas atau hasil kerja peserta didik yang telah melalui proses tersebut kemudian dikembalikan ke yang bersangkutan. Setelah itu, peserta didik dapat memperbaiki pekerjaannya berdasarkan umpan balik yang diberikan oleh pengajar. Berhubung input nilai dilakukan secara manual, pengajar dapat mengubah kembali nilai peserta didik dengan mempertimbangkan hasil dari perbaikan yang telah dilakukan. Akan tetapi, hal tersebut tidak berlaku jika siswa mengerjakan quiz yang sudah di format dalam Google 
Form, terlebih dalam mode "pilihan ganda". Penilaian atau tepatnya scoring akan dilakukan secara otomatis oleh Google Form itu sendiri.

- Schedule (Penjadwalan)

Fitur ini mungkin bisa dikatakan sebagai salah satu fitur Google Classroom yang cukup membantu pengajar dalam mengatur timing kegiatan - kegiatan yang akan dilaksanakan pada Google Classroom, terlebih ketika berada ditengah antara padatnya kesibukan kerja dan keluarga. Dengan fitur ini, pengajar dapat menjadwalkan secara otomatis kapan materi pembelajaran, quiz, serta tugas didistribusikan ke peserta didik untk selanjutnya dapat diakses, dipelajari dan dikerjakan.

- Announcement (Pengumuman)

Pengumuman dapat diposting oleh pengajar ke beranda kelas (di Google Classroom, dikenal dengan istilah Stream) yang selanjutnya dapat dikomentari oleh peserta didik. Berbagai jenis media dengan beragam format, termasuk produk - produk besutan Google seperti video YouTube, file Google Drive, tautan Google Form dan sebagainya dapat dilampirkan ke pengumuman untuk langsung dibagikan kepada peserta didik tanpa harus membuat segmen khusus. Layaknya sosial media, peserta didik juga dapat memposting ke beranda kelas tapi prioritasnya tidak akan setinggi seperti pengumuman yang dibuat oleh pengajar dan dapat dimoderasi.

- Archived Course (Kelas yang Diarsipkan)

Fitur ini memungkinkan pengajar untuk mengarsipkan kelas pada akhir semester atau tahun. Ketika sebuah kelas diarsipkan, maka akan segala detail yang berhubungan dengan kelas tersebut akan dihapus dari beranda dan dipindahkan ke area Kelas yang Diarsipkan untuk membantu pengajar mengatur kelas mereka saat ini. Selain 
itu, saat sebuah kelas diarsipkan, baik pengajar dan peserta didik tetap dapat melihatnya, namun tidak dapat melakukan perubahan sama sekali hingga kelas tersebut dipulihkan.

- Privacy (Privasi)

Berbeda dengan layanan konsumen Google, Google Classroom yang merupakan bagian dari $G$ Suite for Education, tidak menampilkan iklan ataupun konten-konten promosi dalam antarmukanya yang dapat mengganggu konsentrasi penggunanya. Sehingga baik pengajar dan peserta didik bisa lebih fokus dalam kegiatan pembelajaran. Selain itu, data pribadi pengguna tidak dipindai atau digunakan untuk tujuan periklanan. Jadi tak perlu khawatir dengan keamanan privasi, semuanya aman terkendali.

- Originality Reports (Laporan Keaslian)

Ketika fitur laporan keaslian diaktifkan oleh pengajar, fitur ini akan memungkinkan peserta didik untuk mengidentifikasi konten yang tidak dikutip ataupun plagiarisme yang tidak disengaja yang terdapat pada tugas/ pekerjaan mereka. Sistem pada laporan keaslian akan membandingkan tugas / pekerjaan peserta didik dengan halaman web dan buku yang ada di internet. Jika terdapat kemiripan dengan sumber lain, maka mereka dapat melakukan perbaikan sebelum menyerahkan tugas. Saat tugas sudah diserahkan, Google Classroom akan secara otomatis menjalankan fitur ini untuk pengajar dan memberikan laporan keaslian terhadap pekerjaan peserta didik untuk dapat ditinjau oleh pengajar. Pengajar bisa menjalankan pemeriksaan keaslian maksimal lima kali per kelas (sebelumnya tiga kali). Jika menggunakan akun G Suite Enterprise for Education, pengajar akan dapat mendeteksi kemungkinan plagiarisme tidak hanya dari konten online, tetapi juga antar-hasil pekerjaan siswa di sekolah mereka. 
- Offline Mode (Mode Offline)

Fitur ini memungkinkan baik pengajar maupun peserta didik untuk mengakses data-data di Google Classroom tanpa koneksi internet. Dengan adanya mode offline, para peserta didik dapat memulai tugas-tugasnya secara offline seperti melihat tugas yang diberikan, membuka lampiran Drive, serta mengerjakan tugas-tugas di Google Docs. Selain itu, fitur ini juga mempermudah pengajar dalam menilai dan memberi feedback dari tugas-tugas mereka dalam kondisi tanpa internet sekalipun. Dengan begitu penggunaan kuota internet bisa lebih diminimalisir. Sayangnya Google belum mengumumkan secara pasti kapan fitur mode offline ini dirilis secara resmi. Menurut rumor yang beredar, fitur ini akan diluncurkan di tahun 2021 ini.

\subsection{Keunggulan Google Classroom}

Adapun keunggulan Google Classroom dalam pemanfaatannya sebagai Learning Management System (LMS) dibandingkan dengan LMS lainnya dapat dijabarkan sebagai berikut (IdCloudHost, 2020).

- Penyiapan Kelas yang Cepat dan Nyaman

Dibandingkan dengan LMS lainnya yang membutuhkan proses pemasangan yang rumit dan harus terkoneksi dengan server atau provider tertentu, proses pembuatan kelas pada Google Classroom sangat cepat dan nyaman. Pengajar hanya tinggal masuk (login) dengan menggunakan akun Google untuk mengakses aplikasi Google Classroom yang sudah terpasang pada perangkat yang akan digunakan. Selanjutnya, pengajar akan diarahkan pada menu pembuatan kelas. Disana pengajar hanya perlu mengisi beberapa informasi terkait mata pelajaran / mata kuliah yang diampu. Terakhir, pengajar dapat menambahkan peserta kelas dengan mengirimkan kode unik sebagai salah 
satu metode yang bisa digunakan oleh peserta didik untuk bergabung pada kelas yang sudah dibuat.

Begitu semua peserta didik sudah tergabung pada daftar peserta kelas, pengajar sudah bisa mulai membagikan rincian kegiatan pembelajaran, materi pembelajaran, tugas tugas, dsb. Tampilan antarmuka aplikasi Google Classroom tergolong sangat sederhana dan mudah untuk dioperasikan (user friendly), sehingga baik pengajar maupun peserta didik akan merasa nyaman saat menggunakannya. Hal ini tentu akan memberikan pengalaman pembelajaran daring yang lebih baik.

- Hemat dan Efisiensi Waktu

Keseluruhan proses pembelajaran diakomodasi hanya dalam 1 (satu) aplikasi, yaitu Google Classroom yang sudah terintegrasi dengan ekosistem aplikasi Google lainnya. Ini jelas tidak membutuhkan dukungan dari aplikasi lainnya, khususnya yang diluar ekosistem Google. Dengan menggunakan aplikasi Google Classroom, pengajar dapat menyiapkan, mendistribusikan dokumen-dokumen penunjang proses pembelajaran, memberikan umpan balik serta penilaian terhadap semua pekerjaan / tugas peserta didik dengan cepat, di satu tempat. Semuanya dilakukan secara online dan tentunya paperless (tanpa kertas), sehingga tidak ada waktu yang terbuang untuk mendistribusikan dokumen fisik. Peserta didik pun dapat menyelesaikan tugas mereka dengan lebih cepat untuk memenuhi deadline waktu yang diberikan. Dengan demikian, ada potensi untuk penghematan waktu untuk kedua belah pihak baik peserta didik maupun pengajarnya, sehingga jadwal pembelajaran daring dapat disesuaikan dengan jadwal sehari-hari di rumah. 
- Mampu Meningkatkan Kerjasama dan Komunikasi

Salah satu manfaat paling penting dari menggunakan Google Classroom adalah kolaborasi online yang efisien. Pengajar dapat menyampaikan pengumuman ke peserta kelas mereka untuk memulai diskusi online atau memberitahu mereka tentang kegiatan pembelajaran online tertentu. Di sisi lain, peserta didik memiliki kesempatan untuk memberikan umpan balik kepada rekan-rekan mereka dengan mengunggah postingan langsung ke dalam diskusi di Google Classroom. Dengan demikian, jika mereka membutuhkan bantuan karena kesulitan memahami suatu tugas atau ingin mempelajari lebih lanjut tentang topik tertentu, mereka bisa mendapatkan masukan langsung disaat yang bersamaan dari teman sekelas virtual mereka. Pada dasarnya, Google Classroom berfungsi untuk meningkatkan aspek pembelajaran sosial pendidikan online yang memungkinkan peserta didik untuk mendapatkan keuntungan dari pengalaman dan keterampilan rekan belajar mereka.

- Penyimpanan Data yang Terpusat

Semua rekam jejak aktivitas pembelajaran berada dalam satu lokasi terpusat, yakni Google Classroom. Seakan berfungsi sebagai portofolio online, peserta didik dapat melihat nilai untuk semua tugas-tugas yang selama ini telah mereka kerjakan di laman tugas pada aplikasi Google Classroom. Selain itu, semua materi kelas otomatis tersimpan ke dalam folder di Google Drive. Kedua belah pihak tidak perlu khawatir mengenai dokumen atau penilaian yang hilang, karena semuanya tersimpan secara cloud dalam LMS yang gratis ini.

- Berbagi Sumber Informasi yang Efisien, Praktis dan Cepat Dibandingkan harus mengirim email secara individu untuk setiap peserta didik, cukup dengan mengakses aplikasi 
Google Classroom, pengajar dapat mendistribusikan tautan terkait sumber informasi ataupun materi tambahan untuk menunjang pembelajaran mereka. Tidak hanya pengajar, peserta didik pun dapat saling berbagi sumber informasi pada beranda kelas (stream). Cara ini memberikan kesempatan kepada mereka untuk memperoleh informasi terupdate dan real time yang berhubungan dengan pelajaran saat ini, sehingga mereka dapat memiliki wawasan dan pemahaman konsep yang lebih baik.

\subsection{Kekurangan Google Classroom}

Dibalik keunggulan dan segudang fitur yang disediakan, dalam pemanfaatannya sebagai Learning Management System (LMS) ternyata Google Classroom memiliki beberapa kekurangan, yakni:

- Tampilan yang Kurang Atraktif dan Tidak Konsisten

Salah satu kekurangan dari aplikasi LMS ini adalah tampilannya yang sangat sederhana dan cenderung kurang atraktif bagi para peserta didik. Tampilan antarmuka yang sederhana mungkin bagus untuk para pengajar karena memudahkan mereka dalam pengelolaan Google Classroom ini. Terlebih bagi mereka yang termasuk generasi lama dan baru saja mulai menggunakan aplikasi ini tentunya akan lebih mementingkan fungsi daripada tampilan. Namun bagi peserta didik, khususnya generasi milenial, tampilan antarmuka yang sederhana ini mungkin sedikit membosankan bagi mereka. Perubahan pada desain antarmuka serta penggunaan ikon-ikon yang lebih variatif dan adaptif terhadap trend kekinian akan memberikan kesan modern pada LMS ini. Dengan begitu, peserta didik akan merasa betah dan nyaman dalam menggunakannya.

Selain kurang atraktif, tampilan antarmuka Google Classroom juga dianggap tidak konsisten. Dikatakan tidak 
konsisten karena ada sedikit perbedaan tampilan menu pada aplikasi Google Classroom untuk smartphone (mobile) dengan Google Classroom berbasis web yang dapat diakses via komputer dan laptop. Opsi menu yang ditampilkan pada aplikasi Google Classroom mobile lebih sedikit dibandingkan yang versi web. Fitur seperti Create Quiz Assignment yang sudah dilengkapi dengan Google Form juga tidak bisa ditemukan pada versi mobile ini. Dengan kata lain, agar dapat menggunakan semua fitur lengkap Google Classroom, pengajar harus mengakses versi web nya.

- Berkas Tidak Dapat Dikirim Saat Google Drive Penuh Seperti yang diketahui, Google Classroom belum memiliki penyimpanan sendiri, namun terintegrasi dengan mengandalkan aplikasi penyimpanan awan milik Google bernama Google Drive. Dengan kata lain, seluruh berkas yang diunggah atau dikirim ke Google Classroom sebenarnya otomatis tersimpan di Google Drive. Masalahnya muncul ketika kapasitas penyimpanan Google Drive tersebut sudah mencapai batasnya. Berkas atau dokumen yang kita kirim akan mengalami error dan tidak akan terkirim ke Google Classroom. Jika hal ini tidak ditindaklanjuti maka akan menghambat keberlangsungan proses pembelajaran daring. Solusi dari permasalahan ini adalah dengan menginstall alternatif penyimpanan awan (Google Drive) yang baru kemudian dihubungkan ke Google Classroom agar berkas yang dikirimkan dapat tersimpan dengan aman (TeknoGue, 2020; Wayah-e, 2020).

- Tenggat Waktu Hanya Sebatas Wacana

Batas waktu pengumpulan tugas biasanya difungsikan menjadi semacam suatu pengingat ataupun ancaman halus agar peserta didik dapat mengumpulkan tugasnya tepat waktu. Jika terlambat berarti harus ada konsekuensi yang 
diterima, entah tugasnya tidak diterima atau tetap diterima tapi dengan pengurangan skor. Pada saat pembelajaran daring kebanyakan peserta didik yang malas mengerjakan dan mengumpulkan tugas, memanfaatkan kekurangan pada Google Classroom. Salah satunya adalah tetap bisa mengumpulkan tugas walau sudah terlambat dari tenggat waktu yang ditentukan. Beberapa sumber menyebutkan hal tersebut dilakukan dengan cara memundurkan waktu pada perangkat sehari dari tenggat waktu pengumpulan tugas sehingga tugas yang awalnya sudah tidak bisa diserahkan dapat tetap diserahkan. Semoga Google dapat memperbaiki kekurangan ini dengan pengaturan sistem yang lebih tegas, dimana ketika peserta didik terlambat menyerahkan atau mengumpulkan tugasnya, sistem Google Classroom otomatis menutup penerimaan tugas. Sehingga mereka sama sekali tidak bisa mengunggah atau mengirimkan berkas ke Google Classroom.

\section{PENUTUP}

Di tengah pandemi Covid-19, Google Classroom adalah satu LMS yang paling banyak digunakan oleh sekolah, perguruan tinggi dan lembaga pendidikan lainnya sebagai platform pengelolaan kelas untuk menunjang proses pembelajaran jarak jauh yang dilaksanakan secara daring (online). Pembelajaran akan terasa lebih mudah mengingat Google Classroom dapat diakses dimana saja dan kapan saja melalui perangkat (laptop, smartphone, tablet, $d s b$.) yang telah terhubung dengan internet. Berkat fleksibilitas ini, meskipun peserta didik berada di rumah mereka masing-masing, mereka tetap mendapatkan pengalaman belajar yang tidak jauh berbeda dengan saat kelas tatap muka. Yang hanya perlu mereka lakukan adalah menunggu pengajar membagikan materi pembelajaran, tugas dan instruksi untuk kegiatan lainnya di Google 
Classroom. Selanjutnya, mereka dapat belajar dan mengerjakan tugas dengan nyaman, serta berinteraksi dengan pengajar dan teman - teman sekelas mereka pada ruang diskusi virtual yang telah tersedia di Google Classroom. Sistem pembelajaran ini memungkinkan mereka untuk terbiasa belajar secara mandiri dan terstruktur dibawah bimbingan pengajar.

\section{DAFTAR PUSTAKA}

Durahman. (2018). Pemanfaatan Google Classroom sebagai multimedia pembelajaran bagi guru Madrasah pada diklat di wilayah kerja Kemenag Kabupaten Cianjur. Tatar Pasundan: Jurnal Diklat Keagamaan, 12(34), 215-221.

Hapsari, S. A., \& Pamungkas, H. (2019). Pemanfaatan Google Classroom sebagai media pembelajaran online di Universitas Dian Nuswantoro. WACANA: Jurnal Ilmiah Ilmu Komunikasi, 18(2), 225-233.

IdCloudHost. (2020). Mengenal Apa itu Google Classroom: Fitur, Fungsi, dan Keunggulannya. IdCloudHost.com. https://idcloudhost.com/mengenal-apa-itu-googleclassroom-fitur-fungsi-dan-keunggulannya/

Ma'arif, M., \& Murdiono, M. (2021). Pengaruh Pemanfaatan Aplikasi Google Classroom Terhadap Karakter Kemandirian dan Hasil Belajar Peserta Didik di Sekolah Menengah Pertama. Belantika Pendidikan, 4(1), 21-28.

Qomariah, S., Nursobah, \& Lailiyah, S. (2019). Implementasi

Pemanfaatan Google Classroom untuk pembelajaran di Era Revolusi 4.0. SINDIMAS, 1(1), 227-231.

Rahmatunnisa. (2020). 50 Fitur Baru Google Classroom Akan Mudahkan Belajar Online. DetikInet. https://inet.detik.com/cyberlife/d-5130171/50-fitur-barugoogle-classroom-akan-mudahkan-belajar-online 
Silviari, R.A. (2020). Penggunaan Video Conference Dalam Pembelajaran Daring. PanturaNews.com.http://panturanews.com/index.php/pantur anews/baca/254804/22/06/2020/penggunaan-videoconference-dalam-pembelajaran-daring

Surat Edaran Nomor Nomor 36962/MPK.A/HK/2020 tentang Pembelajaran secara Daring dan Bekerja dari Rumah dalam Rangka Pencegahan Penyebaran Corona Virus Disease (Covid-19).

Sutrisna, G., \& Juliari, I. (2019). Using 'Problems' to Promote Students' Writing Skills in EFL. Online Submission.

Sutrisna, G., \& Artini, L. P. (2020). Does Problem-Based Learning Affect Students' Speaking Skill and Attitude toward ELL?. RETORIKA: Jurnal Ilmu Bahasa, 6(2), 131-138.

TeknoGue. (2020). Kelebihan dan Kekurangan Google Classroom. https://guetekno.com/kelebihan-google-classroom/

Wayah-e. (2020). 10 Kelebihan dan Kekurangan Google Classroom yang Wajib Diketahui. https://wayahe.blogspot.com/2020/04/10-kelebihan-dan-kekurangangoogle-classroom-yang-wajib-diketahui.html 